\title{
De grendelpen : een methode ter behandeling van meerfragment- en etagefracturen van de femurschacht
}

Citation for published version (APA):

Reinders, J. F. M. (1985). De grendelpen : een methode ter behandeling van meerfragment- en etagefracturen van de femurschacht. [Doctoral Thesis, Maastricht University]. Rijksuniversiteit Limburg. https://doi.org/10.26481/dis.19850418jr

Document status and date:

Published: 01/01/1985

DOI:

10.26481/dis.19850418jr

Document Version:

Publisher's PDF, also known as Version of record

\section{Please check the document version of this publication:}

- A submitted manuscript is the version of the article upon submission and before peer-review. There can be important differences between the submitted version and the official published version of record.

People interested in the research are advised to contact the author for the final version of the publication, or visit the DOI to the publisher's website.

- The final author version and the galley proof are versions of the publication after peer review.

- The final published version features the final layout of the paper including the volume, issue and page numbers.

Link to publication

\footnotetext{
General rights rights.

- You may freely distribute the URL identifying the publication in the public portal. please follow below link for the End User Agreement:

www.umlib.nl/taverne-license

Take down policy

If you believe that this document breaches copyright please contact us at:

repository@maastrichtuniversity.nl

providing details and we will investigate your claim.
}

Copyright and moral rights for the publications made accessible in the public portal are retained by the authors and/or other copyright owners and it is a condition of accessing publications that users recognise and abide by the legal requirements associated with these

- Users may download and print one copy of any publication from the public portal for the purpose of private study or research.

- You may not further distribute the material or use it for any profit-making activity or commercial gain

If the publication is distributed under the terms of Article $25 \mathrm{fa}$ of the Dutch Copyright Act, indicated by the "Taverne" license above, 


\section{DEGRENDELPEN}

Een methode ter behandeling van meerfragment-en etagefracturen van de femurschacht. 



\title{
DE GRENDELPEN
}

\section{Een methode ter behandeling van meerfragment- en etagefracturen van de femurschacht}

\author{
PROEFSCHRIFT
}

Ter verkrijging van de graad van doctor in de geneeskunde aan de Rijksuniversiteit Limburg te Maastricht, op gezag van de rector magnificus Prof. Dr. F.I.M. Bonke, wolgens het besluit van het College van Dekanen in het openbaar te verdedigen in de Aula van de Universiteit op donderdag 18 april 1985 , des namiddags te vier uur

door

Jean Frédéric Marie Reinders, geboren te Maastricht in 1950. 
PROMOTORES: Prof. Dr.H.A.J.Lemmens

Rijksuniversitein Limburg

Prot. Dr.J.M. Greep

Rijksuniversiteil Limburg

REFERENTEN: Dr.med. K. Klemm

Berufsgenossenschaftliche Unfallklinik Frank fort

Prof. Dr. A.J. vander Linden

Rijksuniversiteit Limburg

Dr.J.D. K. Munting

De Weverziekenhuis Heerlen

Dr. J.W.J.L. Stapert

Rijksuniversiteit Limburg

Druk: Schrijen-Lippertzbv. Voerendaal 
Surgery has its roots in trauma. 

DEEL I : LITERATUURSTUDIE

1. Doelstelling van het onderzoek. 10

2. Definitie en indeling van femurschachtfracturen. 13

3. Het ontstaan van femurfracturen, in het bijzonder 17 meerfragment-en etagefracturen bij verschillende ongevalstypen.

4. Behandeling van meerfragment-en etagefracturen. 22

5. Osteosynthese, vascularisatie en fracturgenezing. 27

DEEL II : DE GRENDELPEN

6. 1. Historische aspecten en achtergronden. 32

6. 2. Biomechanische eigenschappen. 38

6. 3. Indicatiegebied. 40

6. 4. Discussie open versus gesloten operathetechniek. 45

6. 5. Operatietechniek. 48

6. 6. Revalidatie na osteosynthese. 62

6. 7. Specifieke complicaties. 65

DEEL III: NA-ONDERZOEK

7. 1. Inleiding. 74

7. 2. Opsporen van patiënten. 75

7. 3. De methodologie. 76

7. 4. De overleden en niet na-onderzochte patiënten. 76

DEEL IV : ANALYSE VAN HET PATIENTENBESTAND

8. 1. Verdeling naar leeftijd en geslacht. 80

8. 2. Ongevalstoedracht. 80

8. 3. Openengesloten fracturen. 81

8. 4. Fractuurvormen. 82

8. 5. Begeleidende letsels in het atgemeen. 82

8. 6. Begeleidende letsels van het homolaterale been. 8.3

8. 7. Localisatie en uitbreiding van de fracturen. 84

8. 8. Opnameduur. 88

8. 9. Tijdsduur tussen opname en operatie. 85

8.10. Samenvatting. 85

DEEL V : RESUL TATEN VAN DE GRENDELPENOSTEOSYNTHESEN VERSUS DE ANDERE TECHNIEKEN

9. Resultaten van de Grendelpenosteosynthesen. 88

9.1. Operatietechnische problemen. 88

9.2. Grensindicaties voor de Grendelpenosteosynthesen. 90

9.3. Belasting van het been postoperatief. 91

9.4. Tijdstip van dynamiseren. 91 
9.5. Complicaties. 91

9.5.1. Zenuwletsels.

9.5.2. Post traumatische osteitis. 92

9.5.3. Reïnterventies en áanvullende (operatieve) mantregelen. 94

9.5.4. Vertraagde botgenezing. 95

9.6. Samenvatting. 96

9.7. Appendix. 97

10. Resultaten van de niet-Grendelpengroep in vergelijking 123

10.1. Behandelingstechnieken. 123

10.2. Osteosynthesetechnieken in relatie tot de fractuur- 123 vormen.

10.3. Operatietcchnische problemen. 124

10.4. Belasting van het been postoperatief. $\quad 124$

10.5. Complicaties. 125

10.5.1. Zenuwletsels. 125

$\begin{array}{ll}\text { 10.5.2. Postraumatische osteitss. } & 125\end{array}$

10.5.3. Aanvullende (operatieve) maatregelen tot consolidatie 126 van de fractuur.

10.5.4. Vertrangde botgenezing. $\quad 126$

$\begin{array}{ll}\text { 10.6. Samenvatting } & 127\end{array}$

11. Functionele en anatomische resultaten. 129

$\begin{array}{ll}\text { 11.1. Looppatroon. } & 129\end{array}$

11.2. Kniefunctie. 129

11.3. Heupfunctie. 130

11.4. Verschillen in femurlengte. 131

11.5. Asafwijkingen in het frontale wlak. 132

11.6. Asafwijkingen in het sagittale vlak. 134

11.7. Rotatie-afwijkingen. 135

$\begin{array}{ll}\text { 11.8. Arthrosis deformans. } & 136\end{array}$

11.9. Samenvatting. 137

DEEL VI : ENKELE SOCIO-ECONOMISCHE ASPECTEN

12. Socio-economische aspecten. 140

SAMENVATTING EN CONCLUSIES 141

13.1. Samenvatting en conclusies. 141

$\begin{array}{ll}\text { 13.2. Summary and conclusions. } & 147\end{array}$

13.3. Zusammenfassung und Schlussfolgerungen. 151

$\begin{array}{ll}\text { LITERATUUR } & 155\end{array}$ 
DEEL I

LITERATUURSTUDIE 


\section{HOOFDSTUK 1}

\section{DOELSTELLING VAN HET ONDERZOEK}

Door de toeneming van de verkeersdichtheid en de hoge snelheden in het verkeer kunnen letsels ontstatan welke men vroeger, uitgezonderd in oorlogsituaties, slechts incidenteel zag. Tegenwoordig krijgt men patiënten met multipele verwondingen en diverse letsels aan cén extremiteit, zoals meeretage- en verbrijzelingsfracturen, ter behandeling aangeboden (Viernstein 1971, Gilquist 1973, Voorhoeve 1973, Karlström 1977, Fraser 1978. Alho 1980, Haas 1980, Ansorge 1982). De meeste slachtoffers treffen we aan in de categorie automobilisten en motorrijders. Vooral deze laatste categorie vormt met de bromfietsers een zeer kwetsbare groep (Zettas 1979. Behrens 1980). Zij nemen weinig beschermd deel aan hel verkeer, waardoor zij gecompliceerde en ernstig verontreinigde letsels kunnen vertonen.

Dit proefschrift over "De behandeling van meerfragment-en etagefracturen van de femurschacht met behulp van de Grendelpen" behandelt slechis én facet van de problemen die de behandeling van patiënten met ernstige ongevalsletsels met zich meebrengt.

Vór de wereldwijde motorisering werd er over dit soort femurfracturen nauwelijks bericht. Lambotte beschreef als één der eersten in zijn boek "Chirurgie opératoire des fractures" (1913) de behandeling van een 2 -etagefractur met een fixateur externe en adviseerde ter behandeling van meerfragmentfracturen een speciale door hem ontworpen plaat (afbeelding 1 en 2).

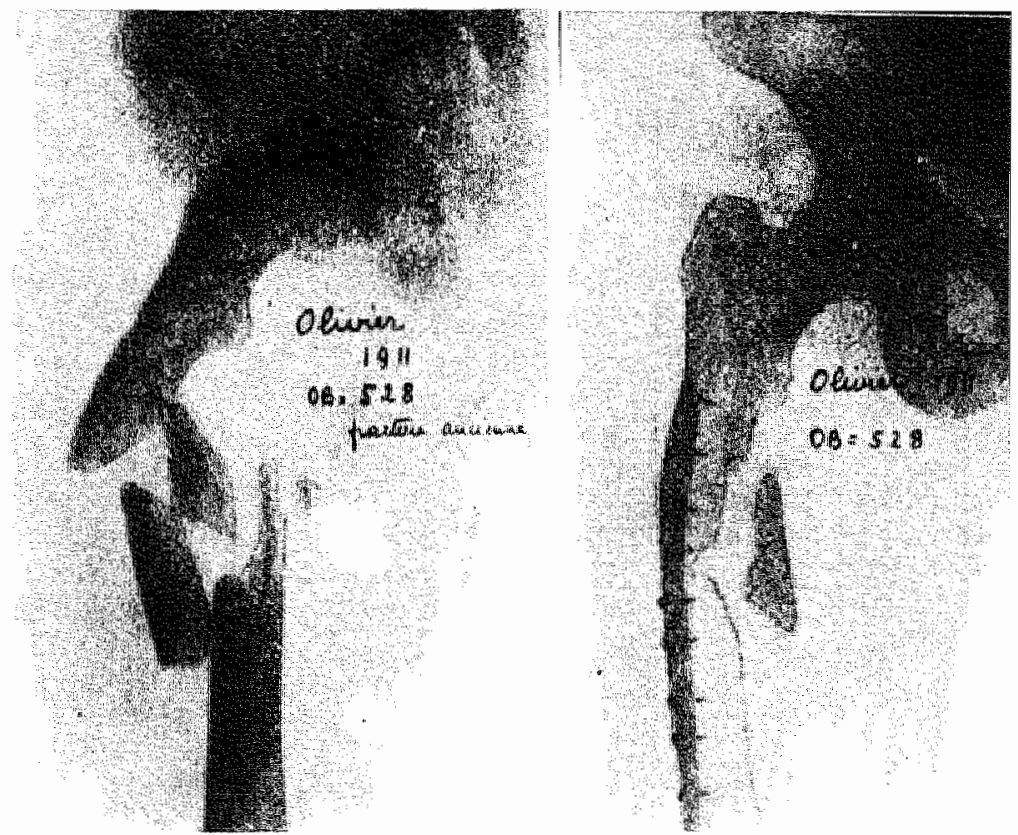

Af7. Meerfragment fractur voorzien van een door Lambotte ontwikkelde plat.

Wii: Lambotte, A. (19)13). 


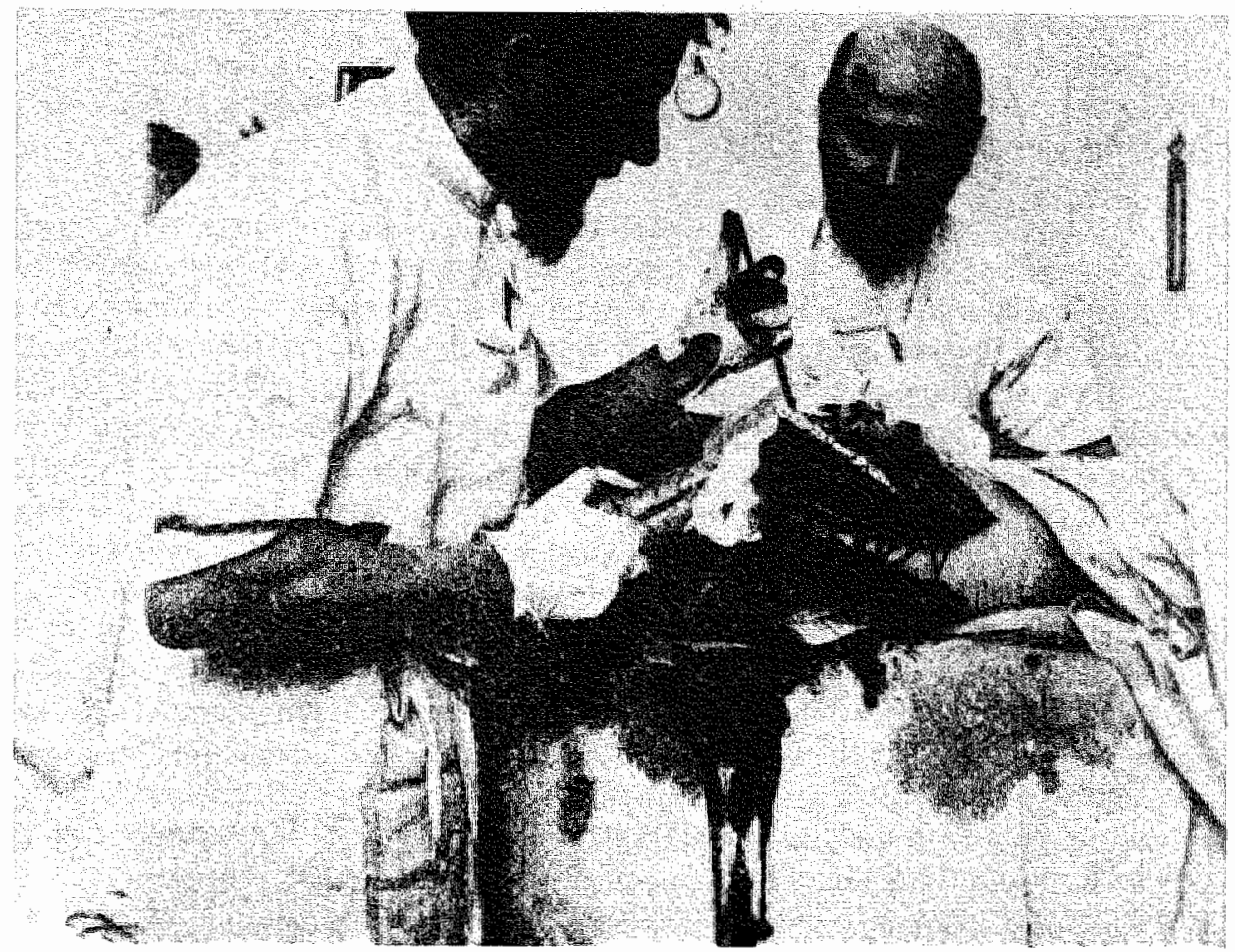

Afb. 2 Lambotte gefotografeerd bij de osteosynuhese van deze frachur.

Uit: Libmbotte. A. (1913).

Algezien van publicaties ontleend aan oorlogservaringen werd er tot de jaren zestig weinig over deze fracturen geschreven. In de overzichten werd voor meerfragmenten etagef racturen geen aparte plaats ingeruimd.

Vanaf het einde der zestiger jaren verschenen er af en toe artikelen die deze fracturen als een aparte groep behandelden. De fracturen werden in kleine series van hoogstens 10-20 patiënten beschreven en op diverse manieren behandeld (Carr 1958, Küntscher 1960 en 1968, Salem 1961, Meuli 1966, Funk 1968, Tscherne 1968, Kuner 1969, Koudsi 1977, Wiendl 1979, Mockwitz 1980, Winquist 1980). Gezien de geringe aantallen en de diverse behandelingsmethoden is het niet mogelijk deze series onderling te vergelijken. Vrijwel iedere auteur hield zijn eigen indeling aan of hanteerde in het geheel geen indeling maar sprak van comminutieve of verbrijzelingsfracturen. Bovendien valt het op dat vele auteurs ook relatief eenvoudige fracturen met één buig- of torsiefragment tot de meerfragmentfracturen rekenden, watardoor hun aantallen geflatteerd werden.

Uit het gepubliceerde materiaal blijkt één ding overduidelijk: deze fracturen zijn moeilijk te behandelen. Het percentage complicaties in de diverse studies variëert $\operatorname{van} 20$ tot $40 \%$. Dit hoge percentage heeft niet geleid tot het verlaten van de operatieve behandeling van deze fracturen.

Slechts enkele chirurgen, waaronder wooral Küntscher, beseften dat de oplossing van de problemen gezocht moest worden in een aan dit soort fracturen aangepaste osteosynthesetechniek. 
In deze studie worden meerfragment-en etagefracturen van het femur als aparte groep bezten. Op basis van een literatuurstudie wordt aandacht besteed aan ontstaanswizen, verschillende indelingen en diverse behandelingsmethoden. De vascularisatie wan het femur bij deze problemfracturen zal besproken worden.

Het doel wan deze sludie is om de resultaten wan de behandeling van deze fracturen met de Grendelpentechniek te analyseren. Hiertoe werden de patiënten uit de Berufsgenossenschaftliche Unfallklinik te Frankfort onderzocht. In deze kliniek werd in 1970 de Grendelpen ontwikkeld door Klemm en Schellmann. Vanaf 1972 wordt de Crendelpentechniek er systematisch toegepast voor de behandeling van alle femurschachtfracturen, zodat een gesloten groep patiènten voor analyse beschikbaar is waarvan de femurtracturen met een Grendelpenosteosynthese behandeld zijn.

Om de behandelingsresultaten van deze envormige groep patiënten in het juiste perspectief te zien, werden de patiënten uit het De Weverziekenhuis te Heerlen eveneens bestudeerd. Bij deze patiënten werden diverse behandelingstechnieken en combinaties van technieken toegepast al naar gelang het type fractuur, de ervaring van de chirurg en het aanwezige osteosynthesemateriaal. Door deze in hetzelfde tijdsbestek op verschillende manieren behandelde patienten te vergelijken met de Frankfort-Grendelpengroep en door de resultaten van beide groepen in detail te bestuderen, kan de Grendelpentechniek in relatie tot de state of the art van andere technicken worden geanalyseerd. De patiëntengroep uit het De Weverziekenhuis is representatiel voor de huidige stand van zaken in de meeste Nederlandse ziekenhuizen, watr men voor de behandeling van deze probleemfracturen niet de beschikking heett over én operatietechniek die speciaal voor deze fracturen werd ontworpen. Het is niet de bedoeling absolute uitspraken te doen aan de hand van de verkregen resultaten. Veeleer is het de bedoeling de resultaten van de Grendelpenosteosynthese te platsen tegen de achtergnond van de resultaten die met de andere behandelingstechnieken in dezelfde periode behaald werden. Tevens zal, watr mogelijk, een vergelijking worden gemakt met gegevens van andere series femurschachlfacturen uit de literatur om de resultaten van de Grendelpentechnick nog meer reliëtlegeven. 


\section{HOOFDSTUK 2}

\section{DEFINITIE EN INDELING VAN FEMURSCHACHT- FRACTUREN}

Een belangrijk probleem bij het vergelijken van resultaten van verschillende series femurfracturen is het ontbreken van een unilorme indeling van de verschillende fractuurtypen. Een tweede probleem vormt het feit, dat het begrip femurschacht niet duidelijk omschreven is.

Auteurs die publiceren over distale femurfracturen, dus condylaire en supracondylaire fracturen, hebben de neiging om het begrip supracondylair ruim te interpreteren, waardoor in deze series ook distale schachtfracturen voorkomen (Altenberg 1949. Bianchi 1955. Stewart 1966. Blaimont 1970. Slätis 1971). Ook het omgekeerde komt voor namelijk dat in publicaties handelend over femurschachtfracturen het begrip schacht te ruim word gebruikt (Dencker 1963. Amihood 1973. Conolly 1973, Thomas 1981, Stapert 1983).

Anatomisch gezien eindigt de schacht daar war de cortex dunner wordt en overgaat in spongieus bot, dus de overgang diaphyse - metaphyse.

Deze overgang verloopt geleidelijk en is al naar gelang de lengte van het femur variabel. Kootstra (1973) loste het probleem van de distale begrenzing van de schacht op door de afstand vanaf de gewrichtsspleet van de knie te nemen die gelijk is an de breedte van het condylenblok (afbeelding 3). Dencker (1963) en Stapert (1983) kozen de distale begrenzing van de schacht op $6 \mathrm{~cm}$ van de kniespleet (albeelding 4). Die begrenzing wordt ook in deze studie aangehouden, daar zij samenvalt met de meest distale femurfractuur die nog met een Grendelpen behandeld kan worden.

Over de proximale begrenzing van de femurschacht, zijnde de ondergrens van de trochanter minor, is er geen discussie (afbeelding 5). Deze begrenzing valt samen met de meest proximale femurfractur watarbij nog een Grendelpenosteosynthese kan worden toegepast.

Er zijn verschillende indelingen voor femurfracturen, die in het allgemeen gebaseerd zijn op één bepaalde osteosynthesetechnick.

Kootstra (1973) en Stapert (1983) classificeerden femurfracturen overeenkomstig de voorstellen van Dencker (1963). Deze definiëerde comminutieve fracturen als fracturen van de femurschacht met minimal vier fragmenten van onbepaalde vorm.

Het merendeel van de auteurs, die over femurfracturen publiceerden, gaf geen definitie en sprak eenvoudig over comminutieve fracturen (Smith 1964, Kuner 1969, Amihood 1973, Conolly 1973, Muhr 1976, Koudsi 1977, Roberts 1977, Klemm 1978, Lüscher 1978, Wilber 1978, Eriksson 1979, Pankovich 1979, Reschatuer 1979. Wiend1 1979, Maess 1980, Buxton 1981, Börner 1983).

Müler (1980) ontwierp een zeer nauwkeurige indeling (afbeelding 6). Deze indeling, die een zeer nauwkeurige documentatie van de morphologie van de fracluur geeft, staat een exacte fractuurdiagnose toe. Voor de toepassing van de Grendelpen is een dergelijke uitgebreide indeling niet noodzakelijk, omdat met de Gren- 


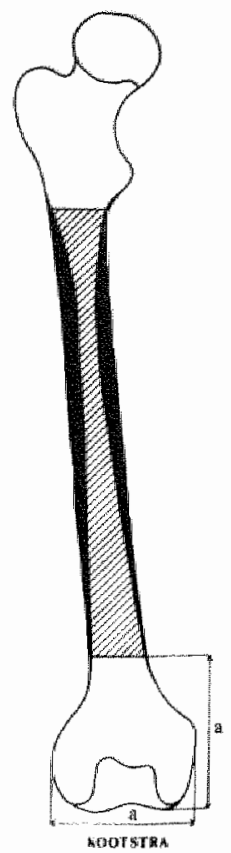

Afb. 3 Kootstra koos als distale begrenzing van de schacht de afstand vanaf de gewrichtsspleet van de knie die gelijk is an de breedte van het condylenblok

(Uit: Kootstra 1973).

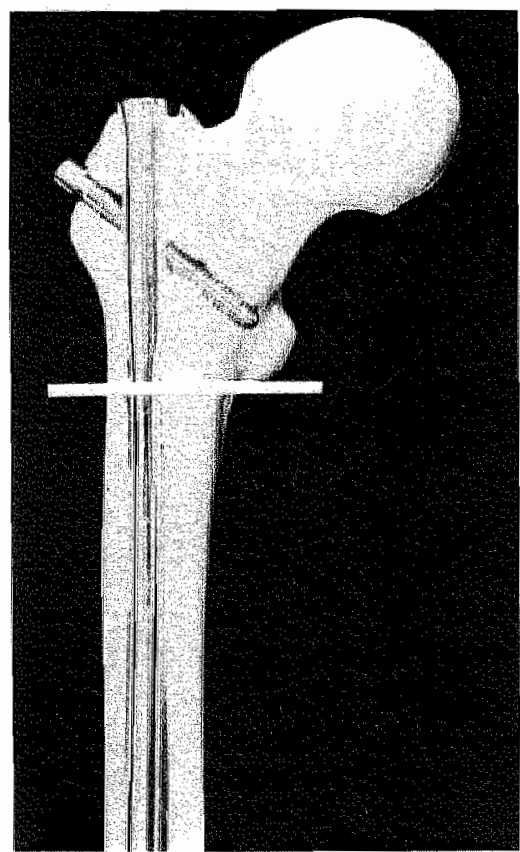

Afb. 5 De proximale begrenzing van de femurschacht wordt door de trochanter minor sewormd.

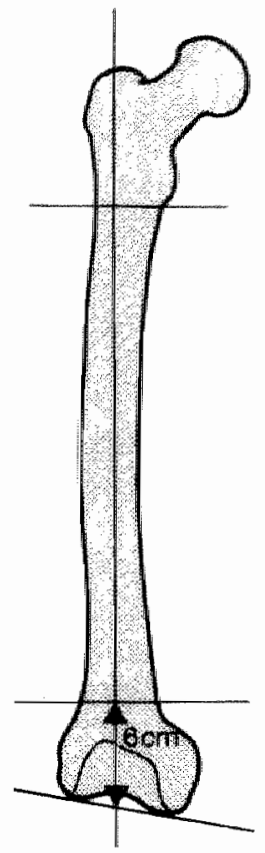

Afb. 4 Stapert en Dencker kozen de distale begrenzing wan de schacht op $6 \mathrm{~cm}$ van de kniespleet

(Uit: Stapert 1983).

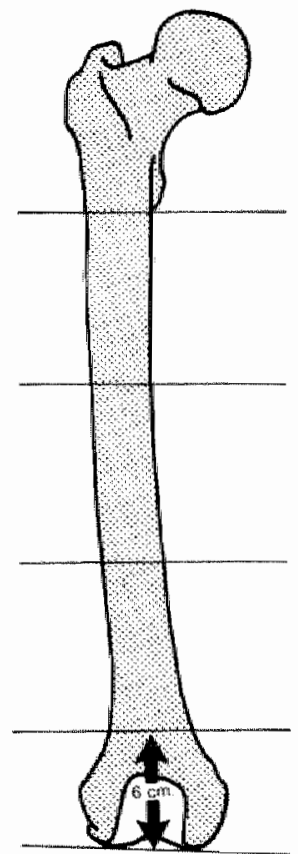

Afb. 7 On de localisatie en de uitgebreidheid van de fractur te kunner aangeven, wordt de schacht in drie segmenten verdeeld. 

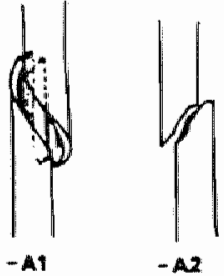

$-\mathbf{A 1}$
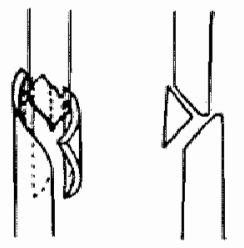

$-81$

$-\mathbf{B 2}$
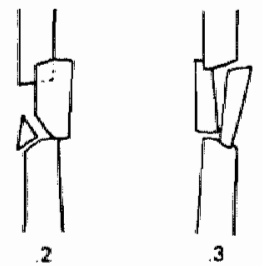

3

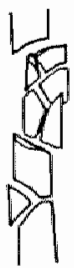

3
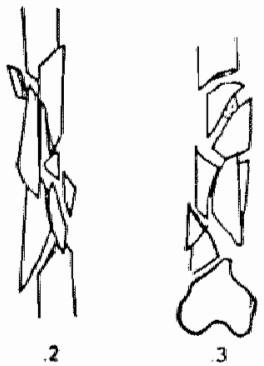

Groep A:

de relatief cenoudige fracturen eventueel met kleinc botsplinters zonder belang $(<1 \mathrm{~cm})$. In doze groep worden drie typen onderscheiden:

A. 1. spiraalfracturen van de fennurschacht.

A.2. schuine fracturen. waarbij de thoek die de fractuurlijn makk met de as yan het femur meer dan $30^{\circ}$ moel zijn.

A.3 dwarse fracturen waarbij de hoek die de fractuurlijn maakt met de as van het femur minder dan $30^{\circ}$ moct zijn.

\section{Groep B:}

fracturen met een derde fragment, hetgeen zelf ook gefractureerd kan zijn.

B.1. fracturen met een enkelwoudig derde fragment, ontstaan door een torsiebeweging.

B.2. idem als B.1, met dit verschil, dat het fragment ontstaan is door een buigmoment.

B.3. in deze groep is tevens het derde fragnent gefractureerd.

Groep C:

de meeretage- en verbrijzeningstracturen.

C.1. de meeretagefracturen.

C.I.1. meeretagefracturen met één intermediair fragment.

C.1.2. idem als C. 1.1. met tewens een "Biegungskeil".

C. 1.3. meeretagef racturu, warbij het intermediaire fragment overlangs is gesplteren.

C.2. de fracturen watrbij de botcylinder volledig gedesintegreerd is en uit 3-5 fragmenten bestat.

C.2.1. verbrijzeling beperkt zich tot de schacht.

C.2.2. idom als C.2.1. warbij echter de fracturering zich voortzet lot in de metaphyse.

C.2.3. idem als C.2.1. met bovendien nog con etagefractuur op een ander schachiniveat.

C.3. de fracturen met volledige werbrijzeling van de botcylinder met meer dan 5 fragmenten.

C.3.1. de verbrizelingszone is niet langer dian 5 $\mathrm{cm}$.

C.3.2. cen verbrijzelingszoune van meer dian $5 \mathrm{~cm}$. die zich beperkt lot de diephyse.

C.3.3. idem als C.3.2. watrbij het fractumgebied utitloopt tot in die metaphyse.

Afb. 6 De classificatie van

femurschachtfracturen zoals deze door M. Müller

(1980) werd ontworpen. 
delpen alle femurschacht fracturen, welke vorm en uitgebreidheid de fractuur ook heeft, gestabiliseerd kunnen worden. Desondanks zal om een vergelijking van de verschillende fractuurvormen bij de Grendelpenosteosynthesen en de andere operatietechnicken mogelijk te maken in deze studie toch van de indeling van Müller gebruik gemaakt worden. Zodoende kan de vorm van de fractuur op een gestandaardiseerde wijze worden aangegeven en kan een relatie tussen de vorm van de fractuur en de gekozen osteosynthesetechniek bij de niet-Grendelpenosteosynthesen worden gelegd.

Evenals in de studie van Tscherne e.a. (1977) over "Mehrfragment- und Trümmerbrüchen des Femurschaftes" worden fracturen vanaf het type B.3. gerekend tot de meerfragment- en etagefracturen. Hierdoor is het mogelijk de resultaten van deze studie op een aanlal punten te vergelijken met de resultaten uit de serie van Tschernee.in.

Om de plaats en de uitgebreidheid van de fractuur te kunnen aangeven, wordt de femurschacht in drie gelijke delen verdeeld (afbeelding 7): het proximale, middelste en distale $1 / 3$ deet. Een onderverdeling van de schacht in zeven of acht delen, zoals Kootstra (1973) en Stapert (1983) publiceerden, is in dit verband minder belangrijk vanwege het andere werkingsprincipe van de Grendelpen. De localisatie van de fractuur is hierbij niet bepalend voor het al dan niet kunnen toepassen van een Grendelpenosteosynthese. Hoogstens bepaalt de localisatie, afhankelijk van het fractuurtype, zoals we later zullen zien, of de pen aan één of aan beide kanten vergrendeld dient te worden.

Resumerend kan opgemerkt worden, dat er in de literatuur geen eenstemmigheid bestaat over het begrip femurschacht. In deze studie is de trochanter minor de proximale grens, terwijl de distale begrenzing op $6 \mathrm{~cm}$ van de kniespleet wordt gekozen. Deze begrenzing van de femurschacht komt overeen met het indicatiegebied van de Grendelpen.

Er bestaan verschillende indelingen van femurfracturen. Ter analyse van de fractuurvormen in de Grendelpen- en de niet-Grendelpengroep zal Müller's indeling worden gebruikt vanwege de exacte fractuurdiagnose van deze indeling. 


\section{HET ONTSTAAN VAN FEMURFRACTUREN, IN HET BIJZONDER MEERFRAGMENT- EN ETAGE- FRACTUREN BIJ VERSCHILLENDE ONGEVALS- TYPEN}

Fracturen ontstaan ten gevolge van druk-, trek-of torsiekrachten of uit een combinatie van deze krachten. Het patroon en de ontstaanswijze van fracturen kunnen verklaard worden met behulp van de elasticitentsleer. De voomatmste principes komen hierop neer (afbeelding 8 en 9 ):

1. Bij buigbelasting ontstat trekspanning aan het convexe deel en drukbelasting op het concave deel van het bot. Hieruit resulteert een dwarse of een schuine fractuur of een fractuur met een buigfragment, een zogenaamde "Biegungskeil". Bij een asymmetrische buigbelasting ontstaat een schuine fractuur. Een zuiver dwarse fractuur treedt op ten gevolge van een gelijkmatige buigbelasting zonder axiale belasting. Bij de combinatie van buig-en drukbelasting ontstad een typische "Biegungskeil", waarbij de fractunr als een dwarse scheur an de convexe zijde begint. Als de "Biegungskeil" als een pijl wordt beschouwd, dan wijst deze altijd in de richting vande inwerkende kracht.

2. Bij een zuivere drukbelasting ontstaat er een reactieve trekspanning in het wak loodrecht op de richting van de druk. De fractuur begint dan als een fissuur an de uiteinden of op enige afstand hiervan. In de regel komt het bij cen drukbelasting tot een buigen van het bot op éen of meer platsen. Wanneer hierbij verschillende bochten in het bot ontstaan, treedt op elk punt van maximale convexitent een "Biegungskeill" op.

3. Bij torsiespanning komt het tot cirkelvormig om het bot heen lopende belastingen die in alle vlakken loodrecht op de as van het bot staan. De fracturering begint op het zwakste punt van het pijpbeen als een dwarse fractuur en breidt zich wan daruit verder uit.

Sjövall (1957) heeft deze biomechanische principes an de hand van fracturen bij patienten overleden aan een trama gecontrolecrd. Hicrbij bleek dat de vorm van de fracturen inderdad verklatard kon worden wit de principes van de elasticiteitsleer.

In het verkeer ontstatn de meeste fracturen uit een combinatie van druk-en buigbelasting. Bij ongevallen met een lage energetische geweldsinwerking ontsian meestal fracturen met én enkele "Biegungskeil". Bij ongevallen met een hoge energetische geweldsinwerking ontstat op verschillende niveaus een "Biegungskeil". Etagefracturen ontstaan in de regel ook uit cen combinatie van druk-en buigbelasting waarbij een vierpuntsbuigbelasting in plaats van de meestal optredende driepuntsbuigbelasting obligat is.

Er zijn een adntal ongevalstypen, waarbij en uitgebreide verbrijzeling van het lemur kan optreden. Op de eerste plats zijn dit de frontale autobotsingen. Hicrbij schuift de bestuurder naar voren, waarna zijn knieën het dashboard raken. Door de toegenomen flexie in de heupen slaan hoofd en romp nar voren en nar beneden, watrbij zij voorruit of stuur raken. Door deze bewegingsvolgorde treden typische 

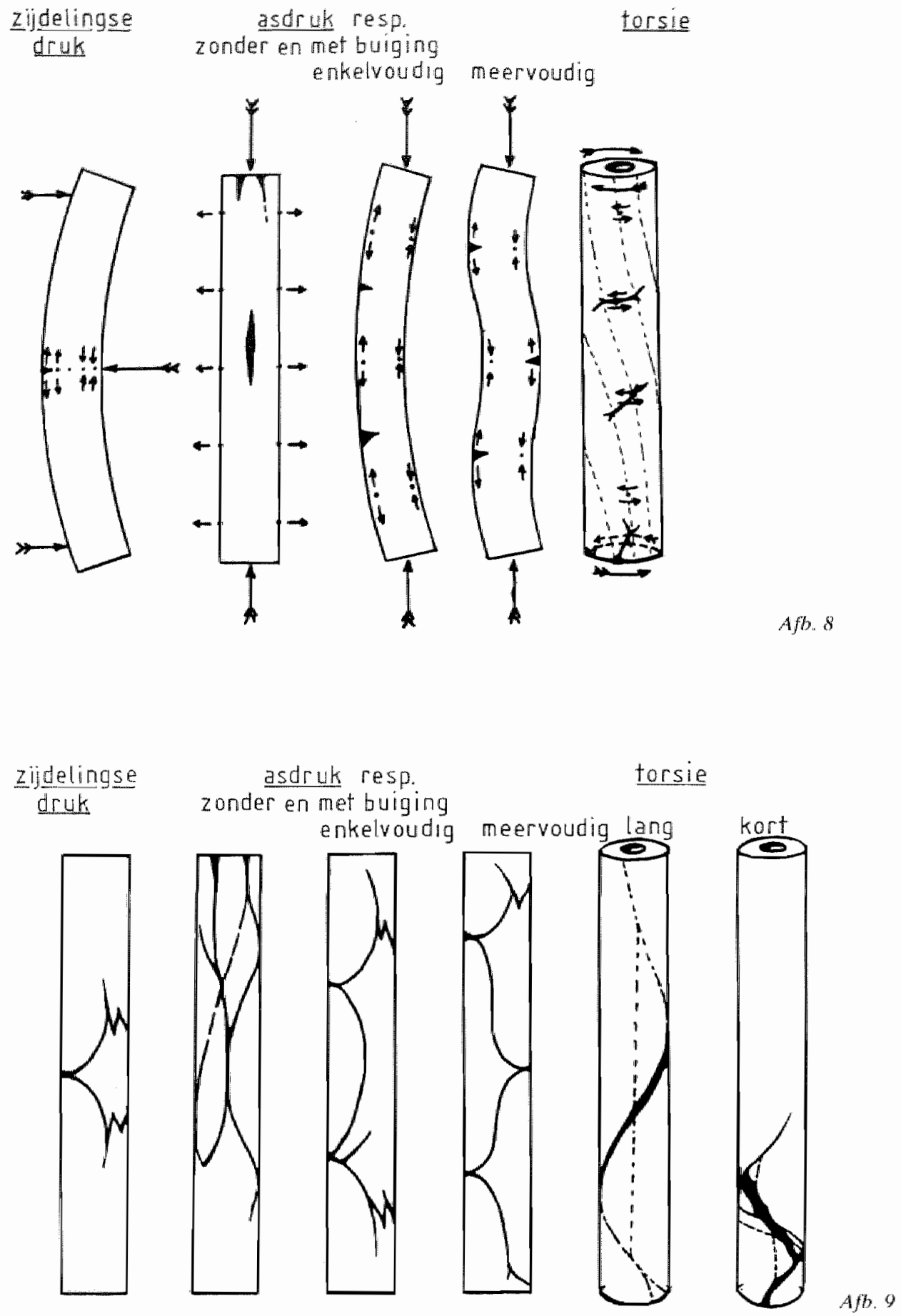

In afbeelding 8 is weergegeven welke spanningen in het bot ontstaan bij buig-, druk-en torsiebelasting.

Afbeelding 9 representeert de hieruil resulterende fracturtypen.

Naar: Sjövall. H. (1957). 
letsels op van heup, knie of femurschacht of combinaties hiervan (Funsten 1938. Smillie 1954, Vollmar 1960, Kimbrough 1961, Bernstein 1974, Casey 1979, Alho 1980). Ritchey c.s. wezen als eersten op het typische karakter en de excessieve verbrijzeling bij deze femurfracturen (Ritchey 1958). Door het feit dat het femur gefixeerd wordt tussen het dashboard en het acetabulum ontstaat een grote axiale drukbelasting op de femurschacht, waaruit een enorme verbrijzeling resulteert. Bechtol (1952) heeft het bewijs geleverd, dat excessieve compressiekrachten, toegepast in de lengterichting van een pijpbeen, leiden tot volledige desintegratie van het trabeculaire systeem, waardoor verbrijzeling over een lang traject ontstaat. Dergelijke fracturen van de schacht treden met name op bij geabduceerde heupen, hetgeen meestal het geval is bij autobestuurders (afbeelding 10). Met de heup in adductie, zoals vaak bij passagiers die met de benen over elkaar geslagen zitten, ontstaan deze fracturen niet, omdat er geen afsteuning van de femurkop in het acetabulum is; hierbij ziet men dan ook eerder een posterieure heupluxatie optreden (afbeelding 11). De plaats van waaruit bij deze ongevallen de eerste geweldsinwerking wordt doorgegeven, is altijd de knie, waarin een deel van de energie geabsorbeerd wordt. De uitgebreidheid van het knieletsel is afhankelijk van de kracht en het contactoppervlak, maar ook van de mate van flexie en fixatie van de knie (Vollmar 1960, Gögler 1968, Nagel 1977).
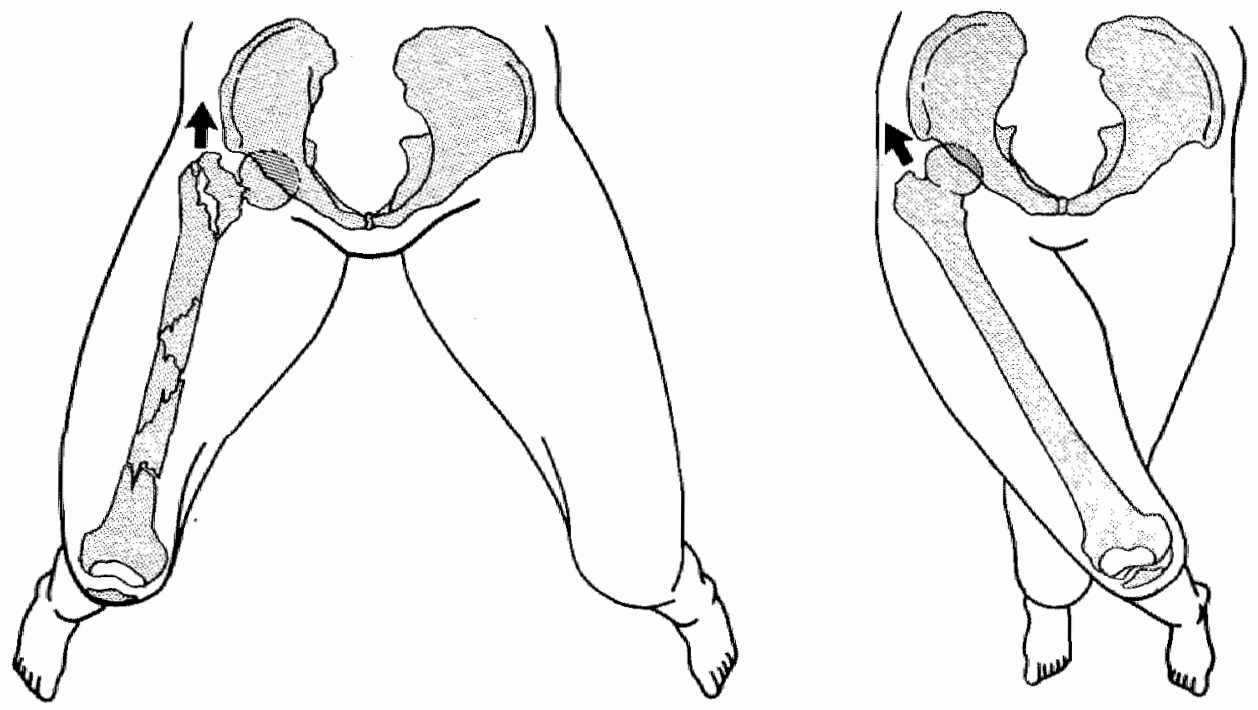

Afb. 10 Bij abductic van the bovenbeen wordt bij een frontale botsing vaak de combinattic meertragmentfractuur wan de schacht en dijbeenhalsfractuur gezien.

Afts. Il Adductie van het bovenbeen leidt eerder tot een luxatie van die femurkop dan toul cen fenurschachtfractuur.

Het grootste deel van de kracht wordt voortgeleid in de lengterichting van de lemurschacht. Bij de combinatie femurhals- en femurschachtfractuur treedt eerst de fractuur van de hals op en de resterende energie veroorzaakt de schachtfractutur. Wanneer er primair een schachtfractuur optreedt, zal de overblijvende energie geen dijbeenhalsfractuur veroorzaken, maar eerder aanleiding geven tot een uitbreiding van het locale letsel, zodat er bijwoorbeeld een open fractuur ontstaat (Viernstein 1971). 
In de groep van de motor- en bromfietsrijders moet de knie ook de eerste klap opvangen (afbeelding 12). Vollmar (1960) onderzocht 150 knieverwondingen ten gevolge van een frontale botsing bij motorrijders. Het bleek dat chinwerkende kracht in $64 \%$ van de gevallen $\mathrm{knieletsels,} \mathrm{in} 30 \%$ letsels van de femurschacht en $6 \%$ heupletsels veroorzaakte. Meer dan $50 \%$ van deze letsels veroorzaakte zeer ernstig tot volledig functieverlies wan the up-en kniegewricht. Motorongevallen zijn in de regel "high speed" ongevallen met een combinatie van buig- en drukbelasting of torsieen drukbelasting op verschillende niveaus, waaruit femurfracturen met verschillende "Biegungs-" of "Drehkeile" kunnen ontstaan.

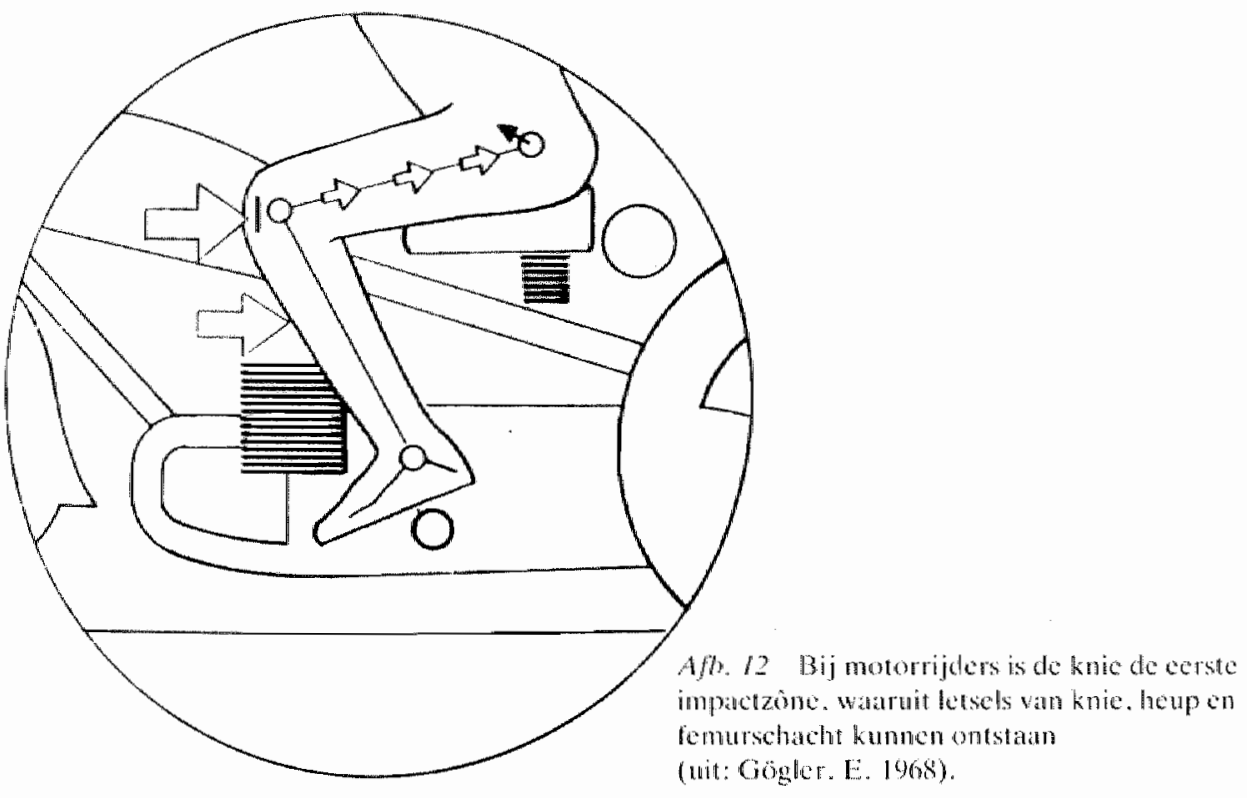

Bij voetgangers worden zelden femurfracturen gezien. Meestal betreft het letsels van onderbeen of knie door een direct contact met de autobumper. Bij kleine kinderen ziet men meer femurfracturen omdat door de geringere lichaamsgrootte de autobumper ter hoogte van het femur komt. Dit zijn enkelvoudige, schuine fracturen wanneer de autobumper rechtstreeks contact makt met het standbeen. Bij een reclitstreeks contact met het speelbeen ontstat een enkelvoudige, dwarse fractuur. Bij oudere voetgangers ziet men, waarschijnlijk ten gevolge van osteoporose, iets vaker femurfracturen. Deze tracturen treden secundair op, doordat de voetganger wordt omgestoten en dan ten val komt. Dit zijn in het algemeen geen verbrijzelingsfracturen (Gotzen 1974). Bij ongevallen in huis ontstaan vaak torsiefracturen. Een korte spiralfractuur ontstaat bij een zuivere torsiebelasting. Bij een combinatie van torsie-en drukbelasting kan een lange spiraalfractuur ontstaan.

Verbrijzelingsfracturen van het femur kunnen ook ontstaan door schotverwondingen; deze ziet men afgezien van oorlogssituaties slechts incidenteel. Schotverwondingen veroorzaken altijd gecompliceerde fracturen, waarbij de verbrijzeling afhangt van het kaliber en de snelheid van het projectiel. Vooral de "high-velocity" kogels veroorzaken een explosieve verbrijzeling. 
Samenvattend kan men stellen, dat fracturen met een zeer sterke verbrijzeling worden veroorzaakt door schotverwondingen, impactieletsels of "high speed" ongevallen. Om het femur te fractureren met een uitgebreide verbrijzeling van de botstructuur zijn grote krachten nodig daar het femur het sterkste bot in het lichaam is. Motorvoertuigen en kogels hebben zulk een potentiële kracht. 


\section{BEHANDELING VAN MEERFRAGMENT-EN ETAGEFRACTUREN VAN HET FEMUR}

Femurfacturen kunnen operatief of niet-operatief (conservatief) worden behandeld. Ook kan een combinatie van een operatieve en een niet-operatieve techniek worden toegepast.

\section{Conservatieve fractuurbehandelling}

De bekendste niet-operatieve technieken zijn tractie, immobiliserende spalken, gipsverbanden en de "cast-bracing"-methode (vroeg-functionele behandeling). In de Angelsaksische landen worden femurfracturen vaak conservatief behandeld; de Perkinstractie alsook de vroeg-functionele behandeling worden veelvuldig toegepast (Perkins 1953, Buxton 1981, Thomas 1981, Sarmiento 1981). Met deze methoden kunnen goede maar geen excellente resultaten bereikt worden.

Buxton (1981) vermeldde de resultaten bij 50 patiënten die met de Perkinstractie werclen behandeld: $40 \%$ van de patiënten toonde een beperking van de kniefunctie tot maximaal $25^{\circ}$. Uit de gegevens van Stryker e.a. (1970) uit het Naval Hospital in San Diego (V.S.) blijkt dat bij militairen waarvan de femurfracturen niet-operatief werden behandeld $63 \%$ uiteindelijk de normale dienst kon hervatten tegen $96 \%$ van patiënten met operatief behandelde femurfracturen. Nichols (1963) berichtte over 181 femurfracturen bij militairen die via operatieve en niet-operatieve technieken werden behandeld. Beide groepen waren qua grootte en samenstelling vergelijkbaar. Opvallend was dat bij $59 \%$ van de patiënten die met behulp van pleistertractie werden behandeld en bij $49 \%$ van de patiënten behandeld met Perkinstractie de knieflexie minder dan $90^{\circ}$ was. In de patiëntengroep waarbij de fractuur met een intramedullaire osteosynthese gestabiliseerd was, bedroeg dit percentage slochts $12 \%$.

Het auntal complicaties van extensietechnieken is niet gering; zo toont het percentage fracturen waarbij een vertraagde consolidatie en eventueel pseudarthrosevor-

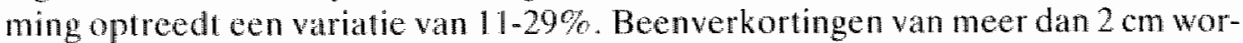
den in 14-30\% van de gevallen gezien, terwijl het percentage refracturen met 4$17 \%$ vrij hoog is (Conolly 1973). De patient verblijft bovendien 3-5 maanden in het ziekenhuis, hetgeen een aanzienlijke kostenfactor vormt.

Bij de extensietechnieken, warbij gebruik gemaakt wordt van een Kirschnerdraad die door de tuberositas tibiae of door het distale femur is geboord, treden regelmatig complicaties op ten gevolge van de draadextensie. Dencker (1963) zag bij $976 \mathrm{fe}$ murfracturen die met behulp van een draadextensie werden behandel in $5 \%$ van de gevallen complicaties ten gevolge van de draadextensie. De meest voorkomende complicaties zijn: het optreden van een infectie rond de Kirschnerdraad, het uitscheuren van de Kirschnerdraad en het optreden wan knieklachten ten gevolge van de te langdurige tractie met een te groot gewicht door de tuberositas tibiae. 
Vanuit de V.S. (Sarmiento 1972. Conolly 1973) heeft vanaf het einde van de zestiger jaren de vroeg-functionele behandeling van femurfracturen aan populariteit gewonnen. Deze behandeling is gebaseerd op het idee, dat beweging van de alangrenzende gewrichten en het functioneren van de spieren een positieve invloed hebben op de fracturgenezing. Kunstofkokers, de zogenaamde "thigh-lacer", maken een normale beweging van de aangrenzende gewrichten mogelijk en vangen een klein deel van de axiale belasting op. De axiale belasting wordt voomamelijk gedragen door de weke delen massa rond het bot, die binnen de niet elastische koker functioneert als een niet-samendrukbare vloeistofstructuur. De koker laat bij belasting een geringe vervorming van de weke delen toe, totdat alle ruimte binnen de koker is opgevuld. Op deze manier is een geringe mate van beweging mogelijk tussen de fractuuruiteinden. Deze beweging is volledig reversibel zodat geen progressieve dislocatie van de fractuur ontstaat. Deze techniek is alleen geschikt voor femurfacturen die in de distale helft van de schacht gelocaliseerd zijn, omdat het bij proximale fracturen niet mogelijk is om met een uitwendige koker de volumineuze weke delen massa voldoende samen te drukken en de fractuur te controleren (Sarmiento 1981).

De fractuurgenezing geschiedt bij de vroeg-functionele methode even snel als bij patiënten met een intramedullaire osteosynthese, terwijl wat betreft de uiteindelijke functie beide groepen vergelijkbare resultaten tonen. Duidelijke verschillen treden op wanneer men het aantal beenverkortingen en asafwijkingen bekijkt.

Conolly (1973) vond in zijn serie bij $43 \%$ van de patiënten een beenverkorting van meer dan $1 \mathrm{~cm}$ en het percentage asafwijkingen groter dan $15^{\circ}$ bedroeg $10 \%$. Met name patiënten met meerfragmentfracturen vertoonden soms forse beenverkortingen. Thomas (1981) vermeldde in een vergelijkende studie naar de behandeling van temurfracturen met tractie, bewegingsgips of intramedullaire osteosynthese vrijwel dezelfde behandelingsresultaten bij de groep vroeg-functionele behandeling en de groep behandeld met een Küntscherpen. De intramedullaire osteosynthese heeft het risico van een infectie en maakt twee operaties nodig. Het grote voordeel van de operatieve methode is het korte ziekenhuisverblijf en het snelle functionele herstel. Bij meerfragmentfracturen is een snelle mobilisatie met cen bewegingsgips gezien de lengte-instabiliteit en het gemakkelijk optreden van asafwijkingen niet mogelijk. Indien deze fracturen vroeg-functioneel behandeld worden, zal eerst 6-10 weken extensie moeten worden toegepast, zodat een beginnende callusvorning het optreden van verkorting of angulatie kan verhinderen.

Jahna en Witlich (1979) beschreven 180 meerfragmentlacturen die zij conservatief met tractie $(n=104)$ of operatief met een Küntscherpen en cerclagedraden $(n=76)$ behandelden. (Van deze 180 fracturen dienen overigens 101 fracturen niet als meerfragment fracturen matar als fracturen met een solitair derde fragment geclassificeerd te worden.) $\mathrm{Bij} 15 \%$ van de conservatief behandelde tracturen trad een ver traagde botgenezing op, waarvoor alsnog operatieve therapie nodig was en bij $10 \%$ moest de extensiebehandeling langer dan 20 weken gecontinueerd worden. De functionele resultaten bij de conservatief en operatief behandelde patiënten ondlicpen elkaar nauwelijks. In de operatief behandelde groep traden zelfs iets meer beenverkortingen op, hetgeen te wijten is aan het feit, dat een Küntscherpen met cerclagedraden bij meerfragmentfracturen niet meer is dan een adaptatieosteosynthese, waarbij verkortingen en rotatie a fwijkingen kunnen optreden. In feite pasten 
Jahna en Wittich twee behandelingsmethoden toe die beide minder geschikt zijn woor de behandeling van meerfagmentfracturen zodat een vergelijking van deze twee methoden niet relevant is en tot verkeerde conclusies kan leiden.

\section{Enderpennen}

De matige resultaten in de behandeling van meerfragmentfracturen met de Küntscherpen hebben ertoe geleid, dat men geprobeerd heeft andere intramedullaire technieken te gebruiken voor deze fracturen. Pankovich (1979) en Eriksson (1979) berichtten over goede ervaringen met de behandeling van femurschachtfracturen door middel van Enderpennen. Een Enderpenosteosynthese geeft stabiliteit tegen buigbelasting doordat, door het opvullen van de mergholte met zoveel mogelijk pennen, een spalkend effect ontstaat. Door het uitwaaieren van de pennen in de remurkop ontstát een zekere torsiestabiliteit. Enige stabiliteit wordt alléén bereikt bij dwarse, enkelwoudige fracturen in het isthmusgebied van de schacht. Wanneer de femurschacht over een lang traject is verbrijzeld, zal een Enderpenosteosynthese slechts een gering reponerend effect hebben, watrbij postoperatief altijd extensie of gipsimmobilisat ic noodzakelijk is. Bij distaal gelegen fracturen bestaat tevens het gevalr dat de inslagopening verder splijt tot in het fractuurgebied, watardoor alle stabiliteit verloren gaat. Bovendien is de neiging tot uitzakken van de pennen bij distale fracturen groot. Vergelijkbare technieken als de "Bündelnagelung" volgens Hackethal en de Rush-pen hebben hun zeer beperkte waarde voor de behandeling van dergelijke fracturen. Dit is in het verleden aangetoond (Ehrlich 1965) en deze methoden zijn dan ook verlaten als behandeling van femurschachtfracturen.

\section{Küntscherpen en cerclagedraden}

Bij femurschachtfracturen met een beperkte verbrijzeling kunnen goede resultaten behaald worden met een Küntscherpen in combinatie met cerclagedraden (Tscheme 1968, Kuner 1969, Muhr 1976, Wiendl 1979, Reschauer 1979). Door de cerclagedraden wordt de botcylinder hersteld waardoor driepuntsfixatie en circulaire elastische inklemming van de Küntscherpen mogelijk is. Nadeel van de methode blijft het feit, dat niet altijd voldoende stabiliteit verkregen wordt, zodat 2$8 \%$ van de patiènten met een antirotatiegipslaars of extensie nabehandeld moet worden.

Het leit dat men cerclagedraden aanbrengt, mag dan theoretisch (Stöhrer 1972. Eitel 1976) niet wan invloed zijn op de periostale circulatie. Om de cerclagedraden atan te brengen. moeten verbindingen tussen periost en weke delen los gemaakt worden, hetgeen, zoals Holden (1972) en Whiteside (1978) hebben aangetoond. een nadelige invloed op de fractuurgenezing heeft. Küntscher (1945), Olssen (1949) en Charnley (1974) wezen het gebruik van cerclagedraden af. Zij waren ervan overtuigd, dut dit de fractuurgenezing negatief beinvloedt.

\section{Zickelpen}

De "Trochanternagel" van Küntscher of modificaties daarvan zoals de Zickelpen (abeelding 18b) kunnen toegepast worden bij meerfragmentfracturen in het proximale $1 / 3$ deel van de femurschacht. Voorwaarde is dat de pen distaal voldoende klemt in de mergholte (Zickel 1980). 


\section{Plaatosteosynthese}

De activiteiten van de A.O.-groep (Arbeitsgemeinschaft für Osteosynthesefragen) hebben ertoe geleid dat het aantal plaatosteosynthesen voor femurfracturen de laatste 20 jaar sterk is toegenomen (Tscherne 1977, Lüscher 1978).

Een plaatosteosynthese biedt stabiliteit doordat de plaat als spalk fungeert. Bij enkelvoudige fracturen bestaat tevens de mogelijkheid interfragmentaire compressie te geven, waardoor de stabiliteit nog aanzienlijk toeneemt. Bij meerfragmentfracturen is interfragmentaire compressie niet mogelijk en fungeert de plat uitsluitend als een extramedullaire spalk. Uit biomechanisch oogpunt zijn er aan de plaatosteosynthese in vergelijking met de intramedullaire osteosynt hese een aantal nadelen verbonden (Leitz 1968). De krachtoverbrenging in een gefractureerd pijpbeen, gestabiliseerd met behulp van een plaat, is lang niet zo effectief als bij een fractuur die van een mergpen is voorzien. Door de op het bot geschroefde plat word de axiale last vanuit het midden van de schacht algeleid naar de rand van het bot juist onder de plaat. Wanneer een deel van de schacht ontbreekt, loopt de krachtoverbrenging volledig via de plaat.

Een ander nadeel vormt het feit, dat soms aan de rand van de plaat een zogenaamde brosse breuk in het bot kan optreden. De brosse breuk is een gevreesd verschijnsel in grote staalconstructies, waarbij de constructie plotseling, zonder dat er enige aanleiding lijkt te bestaan, desintegreert. Tegenwoordig is bekend, dat de brosse breuk enerzijds een materiaalkwestie is en anderzijds kan optreden wanneer op een bepaalde plaats binnen de constructie een ruimtelijke spanningstoestand heerst (Leitz 1968). Een plaatosteosynthese biedt deze "gunstige" voorwarden voor het optreden van een brosse botbreuk.

Een derde nadeel is het fenomeen van de stress-protectie. Het is een bekend verschijnsel dat na het verwijderen van platen er af en toe spontaan of na een minimaal trauma refracturen optreden. Uhthoff (1983) toonde experimenteel aan dat het langdurig in situ laten van metalen platen de botmassa reduceert. Hij cleed dit door hondenfemora, waabij een osteotomie werd verricht, te stabiliseren met een plaatosteosynthese. Het verlies aan bot bleek groter natarmate de plaat meer rigicle was (Uhthoff 1971. Tonino 1976). Laftman (1980) sielde dat de tijd die nodig is voordat het bot weer zijn oorspronkelijke sterkte heeft de helft van de periode bedragt dat de platat in situ is geweest.

De resultaten met name bij de behandeling van meerfragmentfracturen illustreren duidelijk de nadelen van de plaatosteosynthese.

Tscherne (1977) zag in zijn verzamelstudie over plaatosteosynthesen bij meerfragmentfracturen van het femur een percentage vert raagde botgenezingen van $34 \%$.

\section{Fixateur externe}

De mogelijkheid femurfracturen te behandelen met een fixateur externe mag bij fracturen met uitgebreid weke delen letsel als alternatief niet onvermeld blijven. De fixateur externe fungeert als een uitwendige spalk. Het gebruik van een fixateur externe in de behandeling van femurschachtfracturen heeft de latatste jaren duidelijk meer toepassing gevonden.

Vanwege de anatomie van het bovenbeen kunnen de pinnen niet op elke plaats ingebracht worden. De meeste externe fixatiesystemen bestaan uit een uitgebreide constructie van pimnen, staven en verbindingsstukken, hetgeen noodzakelijk is om 
voldoende stabiliteit te verkrijgen. Deze uitgebreide constructie laat weinig of geen dynamische compressie van de fractuuruiteinden toe waardoor de botgenezing wrij traag verloopt.

Hofmann (1982) gaf voor met externe fixatie behandelde meerfragmentfracturen een gemiddelde genezingsdur van 6,2 maanden aan, zodat het gebruik van een fixalteur externe voor gesloten femurfracturen in dit opzicht geen voordelen biedt.

Het zogenaamde dynamiseren van de fixateur externe montage is een mogelijkheid om de fractuurgenezing te bespoedigen. Bij een beginnende callusworming wordt de montage stapsgewijze affgebroken. Allereerst worden de pinnen in het sagittale vlak, die het strekapparaat perforeren, verwijderd. Vervolgens wordt het mediale deel van de constructic afgebroken en als laatste stap wordt bij voltooide botgenezing de laterale component verwijderd. Een andere mogelijkheid is om bij een beginnende botgenezing de fixateur externe volledig te verwijderen en de fractuur verder vroeg-functioneel te behandelen.

Een tweede nadeel van de fixateur externe is de perforatie van het strekapparaat van de knie door cle pinnen, waaruit door het optreden van synechiën vaak een beperkte kniefunctie resulteert ( $\mathrm{Klcmm} \mathrm{1983).} \mathrm{Mogelijkerwijs} \mathrm{kunnen} \mathrm{nieuwe} \mathrm{ont-}$ wikkelingen op het fixateur externe gebied, waarbij een laterale montage allén voldoende stabiliteit biedt, met tevens de mogelijkheid het fixateur externe systeem te dynamiseren, genoemde nadelen opheffen. Voor het femur vormt het ver* lengingsapparaat volgens W:aner een goed alternatief voor de A.O.- of Hof fmann externe fixatie systemen, waarbij een ingewikkelde montage noodzakelijk is. Het verlengingsapparat volgens Wagner kan bij open femurfracturen met ernstig weke delen letsel uitstekend als een zogenaamde monofixateur externe worden toegepast (Marti 1982).

\section{Gecombineerde operatieve en conservatieve behandeling}

Met een niet-operatieve behandelingstechniek is het met name bij meerfragmenten etagefracturen soms onmogelijk om de fractuur op lengte te houden of om asafwijkingen volledig te corrigeren. Dit is de reden waarom in het verleden bij deze fracturen vaak gekozen werd voor een combinatie van een operatieve en een conservatieve behandelingstechniek.

Er werd een dume Kuntscherpen ingebracht die de fractur een zekere lengtestabilitei gaf en asafwijkingen voorkwam. Om het ontbreken van enige torsiestabiliteil te compenseren, werd de patient postoperatief gedurende een zestal weken nabehandeld in een gipsbroek of met tractie (Carr 1958, Salem 1961, Kuner 1969. Winquist 1978). Bij deze gecombineerde behandeling loopt de patiënt alle risico's vande operatieve en de conservatieve fractuurbehandeling.

Vele technieken worden toegepast om femurschachtfracturen te behandelen. Conservatieve en operatieve technieken hebben ieder hun voor-en nadelen. Bij de operatieve technieken is het osteosynthesemateriaal vaak niet in staat om bij meerfragment- en etagefracturen voldoende stabiliteit te geven. Sommige osteosynthesetechnieken voegen bovendien een groot additioneel trauma aan de vascularisatie van het bot toe. Met conservatieve technieken is het niet altijd mogelijk een goede repositie van de fractuur te verkrijgen, terwijl de functionele en anatomische resultaten in het algemeen minder goed zijn dan met operatieve technieken en het percentage fracturen met een vertraagde botgenezing aanzienlijk is. 


\section{HOOFDSTUK 5}

\section{OSTEOSYNTHESE, VASCULARISATIE EN FRACTUURGENEZING}

De arteriële doorbloeding van een lang pipbeen bestat uit twee componenten: hnet medullare en het periostale varatsysteem. Het medullare systeem word gevormd door de arteria nutritia en de metaphysaire vaten, die onderling rijkelijk anastomoseren (afbeelding 13) (Trueta 1964, Rhinelander 1968, Brookes 1971 , Holden 1972. Schweiberer 1974, Eitel 1980).

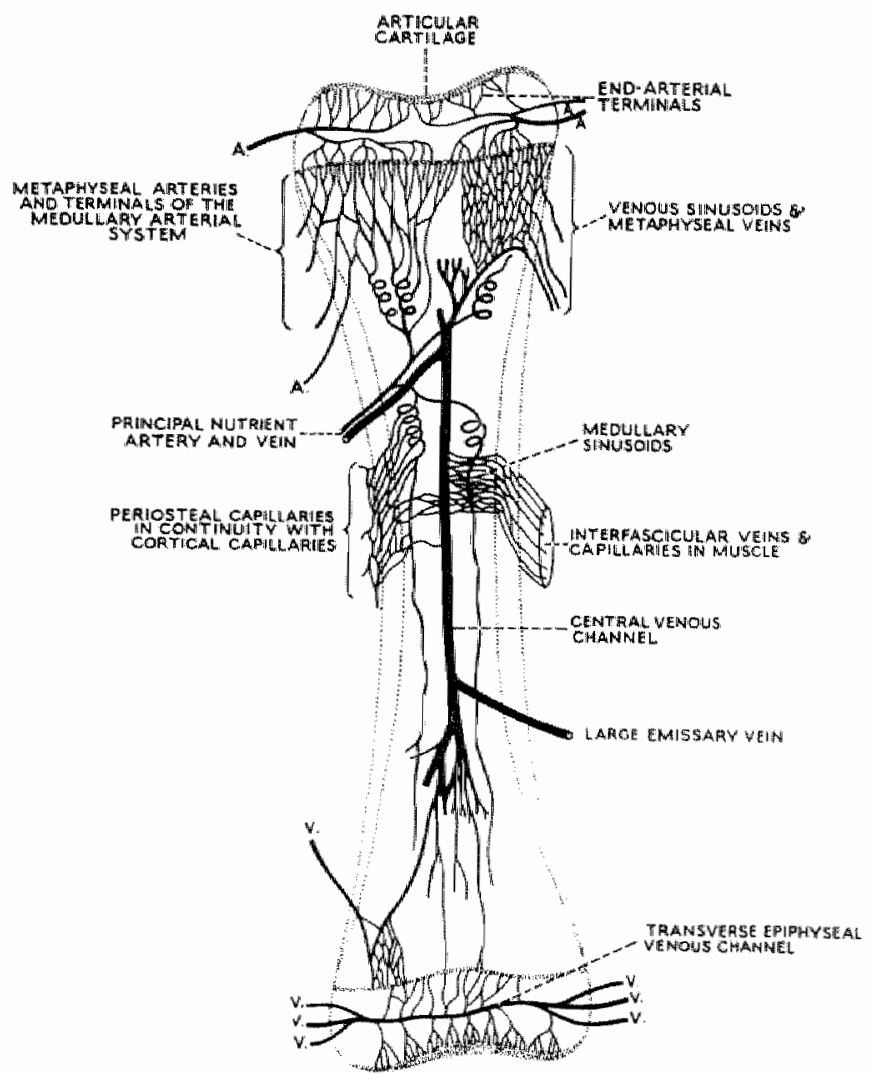

Afly. 13 Vascularisatic wate en pijpben volgens Brookes.

(Uit: Brookes 1968)

De laatste jaren overheerst de mening, dat het medullaire systeem dominant is en de bloedstroom vanuit de mergholte naar het periost gericht is, d. w z. centrifugall Nelson 1960, Rhinelander 1962, Trueta 1964, Dambe 1971. Holden 1972.

Schweiberer 1974, Eitel 1980). Via het medullaire systeem word het binnenste $2 / 3$ deel van de cortex wan bloed voorzien. Alleen de subperiostad gelegen cortex word rechtstreeks door de periostale vaten gevasculariseerd. Vanuit de arteria nutritia en haar zijtakken stroomt het bloed via het capillare systeem van do contex 
naar de capillairen en venen van het periost. Volgens Brookes treed er bij onderbreking wan her medullaire systeem een omkering van de bloedstroom op hetgeen zou betekenen dat er directe verbindingen tussen de medullaire en de periostale cir. culatie bestan (Brookes 1961).

Deze omkering van de stroomrichting kon dierexperimenteel niet bevestigd worden; wel bestat er vanuit het periost een mogelijkheid tot geleidelijke revascularisatie van de cortex (Rhinelander 1962, Trueta 1964, Dambe 1971, Hams 1974,

Hildebrandt 1979. Eitel 1980). De eerste twee tot vier weken treedt er nog geen herstel van de medullaire vaatboom op. De van het periost uitgaande vaten bere:ken pas na twee weken de mergholte en leiden daar tot een beginnende endostale wederopbouw van het vaatsysteem (Höster 1981). Schweiberer e.a. (1973, 1974. 1978) ontkenden op grond van hun onderzoekingen een dergelijke revascularisatie uitgaande van het periost. Dit komt waarschijnlijk ondat zij bij hun onderzoek alleen gebruik maaklen van pennen waarbij de mergholte niet werd opgeboord, zodat het medullaire systeem niet of nawwelijks beschadigd werd. Dambe (1971) zag na het imbrengen van een pen in een niet opgeboorde mergholte een vrijwel intact medullair vatsysteem. Trueta (1964) beschreef dat na onderbinding van de arteria nutritia het medulaire systeem via de amastomosen met de metaphysaire vaten gevuld werd.

Volgens Rhinelander (1980) treed bij een fractuur op drie platsen callusformatie op. Vanuit de mergholte wordt een endostalle callus gevormd. Periostaal ontstat een callus die gevasculariseerd word door het periost. Als derde vormt zich een zogenaamde intercorticale callus, die via de mergholte en het periost gevoed wordt. De grootte van deze callus is a fhankelijk van de ruimte tussen de fragmenten en kan bijeen osteosynthese met een compressieplaat volledig afwezigzijn.

Kessler (1983) toonde aan dat een fragment dat niet anatomisch gereponeend wordt, maar dat men op zijn plaats laat in het fractuurhatematoom zoals bij een gesloten ingebrachte Grendelpen, zeer snel gerevasculariseerd word enerzijd door de nog intacte periostale vaten en anderzijds door nieuwe vaten die vanuit het callusweelsel ingroeien. Deze nicuwe vatingroed revasculariseert het losse fragment sneller dan de intacte periostale vaten dit kunnen doen en is zeer belangrijk voor de lracturigenezing.

Verschillende osteosynthesetechnieken kunnen de revascularisatie ieder op thun eigen wijze nadelig beinvloeden. Een plaat heeft een negatieve invloed op de vascularisatie van de cortex direct onder de plat (Olerud 1968, Rhinelander 1972). Om een plat te appliceren, moet bovendien de weke delen mantel in het fractuurgebied van het periost gesepareerd worden, hetgeen zoals Holden (1972) en

Whiteside (1978) aantoonden een sterk negatieve invloed op de fractuurgenezing heeft. Een platosteosynthese voegt, zoals na opboren van de mergholte voor een pen, geen extra schade toe aan de vaten in de mergholte. Een mergpen, die zonder opboren wordt ingebracht, geeft slechts een geringe beschadiging en drukt de vaten als het ware opzij. Ook een pen met op doorsnede een $V$-vormig profiel geeft minder beschadiging (Schweiberer 1970, van de Berg 1972). Door het opboren van de mergholte treedt $\mathrm{er}$ volgens verschillende auteurs een ernstige beschadiging van de mergvaten op, zodanig dat het binnenste deel van de contex avasculair wordt (Trueta 1955. Göthman 1960, 1961, Dankwardt-Lillieström 1969, 1970, Rhinelander 1974). Pfister (1979), Störmer (1980) an Wesss (1981) lieten exact zien welke effec- 
ten het opboren heeft. Tijdens het opboren ontstaat een druk van $500-800 \mathrm{~mm} \mathrm{Hg}$ in de mergholte met pieken van $1.500 \mathrm{~mm} \mathrm{Hg}$. Door deze enorme drukverhoging raken hef kanaal van de arteria nutritia en de fijne intracorticale kanaalsystemen verstopt met vet en boormeel. De temperatuur loopt in de binnenste cortexlagen op tot $50^{\circ} \mathrm{C}$. Dankwardt-Lillieström e.a. (1970) toonden in een experimentele sludie over de intracorticale circulatie van de tibiaschacht bij konijnen aan, dat de beschadiging beperkt kon worden door het continue afzuigen van de mergholte. waardoor de intramedullaire druk verlaagd word.

Bij een pen met opgeboorde mergholte vindt revascularisatie plaats vanuit de periostale vaten. Pas na zes tot acht weken heelt de medullaire vatatboom zich hersteld en neemt deel aan de revascularisatie van de cortex. Geleidelijk aan neemt het medullaire systeem de doorbloeding van de cortex meer en meer over en in de eindfase van de botgenezing is de bloedstroom weer volledig centrifugaal gericht (Stormer 1.980).

Weiss (1981) toonde aan, dat de instandhouding van het periost bij een meerfragmentiractuur uiterst belangrijk is voor de periostale revascularisatie. Hij veroorzaakte bij honden een gestandaardiseerde 2-etagefractuur van de tibiaschacht. Het intermediaire schachtgedeelte werd verwijderd en daarna weer teruggeplatst. warna aansluitend een osteosynthese van de fractuur plaatsvond met behulp van een Grendelpen. Bij de ene helft fracturen werd het intermediaire schachtgedeelte volledig ontdaan van zijn periostmantel, terwijl bij de andere helft de verbinding tussen bot en periost zorgvuldig werd gespaard. Het bleek dat de botfragmenten. waarbij het periost intact was gelaten, veel sneller revasculariseerden dan de gedeperiosteerde botstukken. Hij bewees hiermee welke grote voordelen de gesloten operatietechniek bij een penosteosynthese heeft tegenover de open operatietechmiek. Bij de gesloten operatietechnick blijft de verbinding van het periost met het bot intact, hetgeen een belangrijke rol bij de periostale revascularisatie speelt. De conclusie van Weiss was dan ook, dat het behoud van de vitaliteit van de losse fragmenten bij een via de gesloten operatietechniek ingebrachte pen, ook al treedt bij een penosteosynthese een vertragde medullaire circulatie op, eerder gegarandeerd kan worden dan na stabilisatie met een plaat.

Schweiberer e.a. (1974) achtten na een stabiele plaatosteosynthese de situatie wat betreft de revascularisatie van de cortex gunstiger dan bij een pen met opgeboorde mergholte, omdat zij dierexperimenteel konden aantonen, dat er bij cen plaatosteosynthese reeds na 2 weken een herstel van de medullaire vaatboom optreedt. Schweiberer e.a. Waren ervan overtuigd, dat revascularisatic van de cortex altijd via het medullaire vaatsysteem plaatsvindt. Deze stelling betekent dat nauwkeurige inpassing van losse fragmenten (via een trekschroef of een platosteosynthese) de beste vooruitzichten zou moeten bieden voor heraansluiting aan de mergvaten. Met experimenteel onderzoek toonden Schweiberer e.a. (1974) echter aan, dat fragmenten die niet nauwkeurig ingepast worden met intact blijven van de periostatle verbindingen veel sneller gerevasculariseerd worden dan gedeperiosteerde en exact ingepaste fragmenten. Schweiberer e.a. verklaarden deze discrepantie tussen hypothese en experimentele bevindingen door aan te nemen, dat er storingen in de intraossale veneuze stroombaan bestaan die een snelle revascularisatic van exact ingepaste fragmenten verhinderen. Een bevredigende weergave van de intraossale veneuze stroombaan is nog niet mogelijk. 
Vergelijkend, experimenteel onderzoek naar de botgenezing van plaat- of penosteosynthese geeft wisselende resultaten. Een snellere botgenezing na plaatosteosynthesen werd gewonden door Gustilo (1964), Braden (1976), Mihula (1973) en Rand (1981). Geen verschil in genezingsduur toonden Reynolds (1954) en Barron (1977) aan. Braden (1973) toonde aan dat de biomechanische kwaliteit van de callus bij een intramedullaire osteosynthese beter is. De verschillende resultaten kunnen verklaard worden door het feit, dat voor de fractuurgenezing niet alleen de vascularisatie maar evenzeer de mate van stabiliteit van de osteosynthese van belang is. Bij teveel instabiliteit (Wang 1981) treedt een vertraagde consolidatie op. Eitel (1981) concludeerde dat bij een plaatosteosynthese instabiliteit tot een vertraagde consolidatie leidt. Dit speelt vooral een rol bij meerfragmentfracturen waar een plaatosteosynthese nooit meer kan zijn dan een adaptatie-osteosynthese. Bij een pen zal eerder de avasculaire binnenste cortex aanleiding geven tot een vertraagde consolidatie. Interessant zijn in dit verband de resultaten van door Hörster (1981) verricht onderzoek naar de revascularisatie van met een osteosynthese gestabiliseerde fracturen bij patiënten die na enkele weken tot maanden ten gevolge van het trauma overleden. Zelfs bij fracturen waarbij de mergholte sterk was opgeboord, bleek na twee weken een revascularisatie van het endost op te treden via de periostale vaten. Bij plaatosteosynthesen trad er geen sneller herstel op van de medullaire circulatie. Mogelijk is de beschadiging van het medullaire vaatsysteem door het opboren van de mergholte niet zo ingrijpend als aan de hand van dierexperimenten verwacht zou kunnen worden. Het aanbrengen van een plaatosteosynthese bij verbrijzelingsfracturen is in principe mogelijk, maar technisch niet eenvoudig. Bovendien bestaat het gevaar dat door het afschuiven van het periost en de weke delen fragmenten avasculair worden. Bij een via de gesloten operatietechniek ingebrachte Grendelpen wordt de vascularisatie van de losse fragmenten behouden via de intacte periostale vaten zodat er geen sequesters ontstaan. Aan het contactoppervlak tussen botfragmenten en callusweefsel vindt een ingroei van nieuwe vaten plaats, zodat het botfragment in korte tijd volledig geintegreerd wordt in het vaatsysteem van de callus.

Samenvattend kan men stellen, dat op experimentele gronden (Weiss 1981, Kessler 1983) juist cen via de gesloten operatietechniek ingebrachte Grendelpen wegens het snelle herstel van de botcirculatie een ideale stabilisatie vormt voor meerfragment-en etagefracturen. 
DEEL II

DE GRENDELPEN 


\section{HOOFDSTUK 6}

\section{DEGRENDELPEN}

\subsection{Historische aspecten en achtergronden}

Het idee om schachtfracturen met intramedullaire technieken te stabiliseren, is reeds oud. Bruns berichtte in 1886 over de behandeling van pseudarthrosen. Hij beschreef de resectie van de pseudarthrose en het spalken van de schacht met een intramedullair ingebrachte ivoren stift. In zijn boek "Die Lehre von den Knochenbrüchen" vermeldde hij, dat ook Heine (1875), Bardenheuer (1875) en Socin (1879) deze methode succesvol toepasten. Bircher (1886) ging nog cen stap verder; hij gebruikte deze techniek om "verse" fracturen te behandelen met name zoals hij het noemde fracturen met "rebellischen Dislocationen", die op de gebruikelijke, conservatieve wijze niet in een acceptabele stand te brengen waren.

Het begrip pen (Duits: Nagel) werd in 1902 door Lejahrs ingevoerd, die erop wees, dat de (ivoren) pen zo lang mogelijk diende te zijn en verder goed moest passen in de mergholte. In 1890 verscheen Gluck's referaat getiteld 'Die Invaginationsmethode der Osteo- und Arthroplastik" "in de Berliner Klinische Wochenschrift. Hierin beschreef hij het gebruik van metalen pennen, die proximaal en distaal van de fractuur aan het bot werden verankerd met behulp van ivoren stiften. Dit was feitelijk een soort Grendelpen, een voorloper van de door Küntscher ontwikkelde "Detensionsnagel", later" Verriegelungsnagel" genoemd.

Tot 1930 werd met diverse materialen geëxperimenteerd als spalk voor de mergholte onder andere ivoor, hoorn, visbeen, lijkenbot, zilver, staal, magnesium en vers autoloog bot. Daarna werden vrijwel uitsluitend nog draden, stiften of pennen van metaal gebruikt. Rehn en Wakbaiasky testten in 1911 stiften gemaakt van hoorn en pasten deze met succes in de praktijk toe. Schön (1913) was een groot voorstander van zilverstiften ter behandeling van antebrachiusfracturen. Hoglund (1916) propageerde hel gebruik van een autologe botspaan als intramedullaire spalk (afbeelding 14) die met autologe botschroeven gefixeerd diende te worden. Hey Groves (1918) gebruikte diverse soorten metalen pennen ter behandeling van femurpseudarthrosen na schotverwondingen. Müller-Meernach (1933) was de eerste die op grote schaal roestvrij staal gebruikte. Hij spalkte de mergholte met behulp van smalle metalen platen. De gebroeders Rush introduceerden in 1937 een dunne metalen pen die later zeer bekend werd als de Rush-pen (afbeelding 15). Deze massieve pen, die lichtgebogen en elastisch was, had het voordeel, dat ze door haar vorm en elasticiteit gemakkelijk te introduceren was. Een nadeel was de geringe stabiliteit die deze vorm van intramedullaire osteosynthese bood.

Het opvullen van de mergholte met een of meer metaaldraden werd door Lambotte (1907) als én der eersten toegepast. Ook na de invoering van de Küntscherpen bleven diverse auteurs (Landelius 1951, Böhler 1966) deze techniek propageren, met name voor fracturen van de onderarm, waar de starre Küntscherpen moeilijk te introduceren was. Hackethal (1961) perfectioneerde deze methode en noemde haar "Bündelnagelung". Het principe bestaat hieruit, dat men zoveel mogelijk staaldraden introduceert on de mergholte te spalken. Bovendien probeert men de stabiliteit te vergroten door de draden zoveel mogelijk te laten uitwaaieren in de meta- 

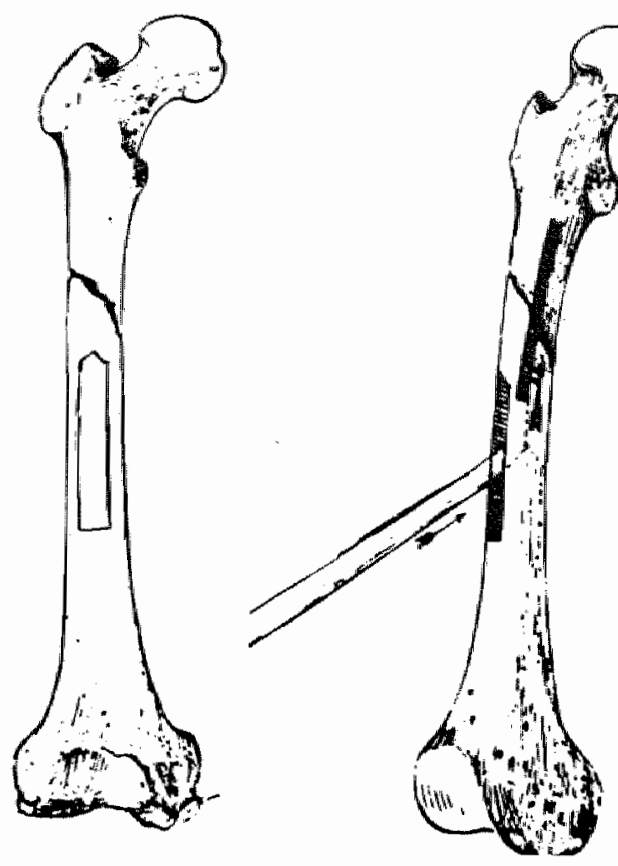

Afb. If Het gebruik van een autologe botspann ter heluandeling van een femurschachtractuur. zoals Hoglund dit propageerde.

(Uit: Hoglund 1916)
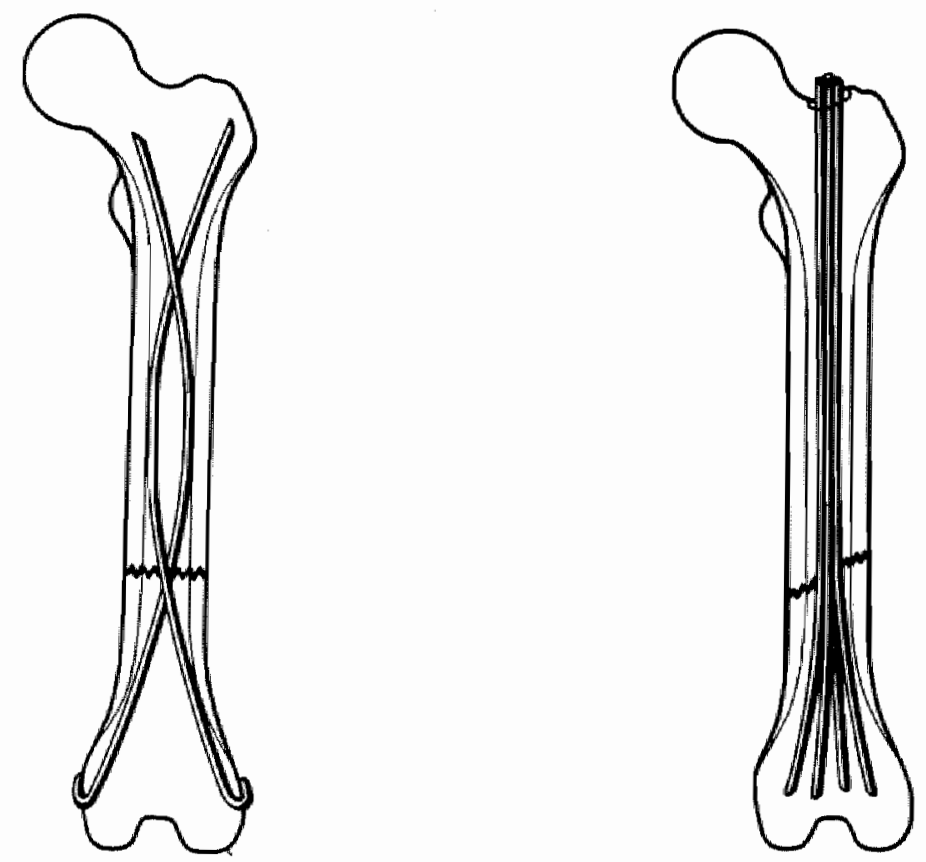

A/b. 15 Stabilisaric van ex femurfractuar met 2 Rush-pennen.

Afb. 16 De "Bündelnagelung" voligens:

Hackethal was bij enkelvoudige dwarse fracturen ook op het femur toepasbat. 
physaire spongiosa. Deze "Bündelnagelung" vormde een compromis tussen het onstabiele spaken van de mergholte met én enkele dunne metaaldraad en de stabiele spalking met een Küntscherpen. De methode heeft nooit veel toepassing gevonden, omdat de stabiliteit vaak te wensen overliet en het indicatiegebied nauwelijks groter wax dun dat van de Küntscherpen. De methode was vooral voor de tibia en de humerus bedacht en was met name bij enkelvoudige, dwarse fracturen ook op het femur toepasbaar (atbeelding 16).

Voor de behandeling van per-en subtrochantere femurfracturen worden de pennen volgens Ender, in het Duits "Federnagel", sinds 1969 op grote schaal toegepast. Via een opening net boven de mediale femurcondyl worden zoveel mogelijk dunne, elastische pennen ingebracht die men in de femurkop laat witwaäeren.

Na uitgebreide dierexperimenten werd door Küntscher in november 1939 de eerste door hem ontwikkelde pen ingebracht bij een 35-jarige scheepsbouwingenieur met een subtrochantere femurfractuur. Hij stelde zijn methode vervolgens in 1940 in het openbaar voor op het Duitse chirurgencongres in Berlijn. Ondanks heftige kritiek van toonaangevende collega-chirurgen vond Küntscher"s methode snel wereldwijde verbreiding. Tijdens de Tweede Wereldoorlog werden er vele, vaak meerfragmentlracturen ten gevolge van schotverwondingen gezien. Nadat Küntscher in 1940 zijn pen had geïntroduceerd, lag het voor de hand dat er tijdens de oorlog chirurgen waren, die Küntscher's methode wilden benutten voor de behandeling van deze fracturen. Er ontstond dan ook onder de Duitse legerchirurgen een levendige discussie omtrent het al dan niet behandelen van deze fracturen met een pen (Westhues 1943, Bauer 1943, Heim 1943, Böhler 1943, Raisch 1943). Als "Oberstabsarzt" stelde Böhler zelfs voor deze fracturen direct op de verbandplaats vanuit de fractuur te pennen zonder röntgenfaciliteiten. Raisch bekritiseerde dit advies ten stelligste en verdedigde zijn stelling met een uiteenzetting over door hem gedane dierexperimenten. Hij stelde voor om eerst een uitvoerig debridement van de wond te verrichten en de fractuur met extensic of gipsbroek te immobiliseren en dan in tweede instantie, bij afwezigheid van enig teken van infectie, een penosteosynthese te doen. Heim deelde deze mening en legde de nadruk op het gesloten, dus nict via de fractuur, inbrengen van de pen.

Küntscher heeft voordurend geprobeerd door wijzigingen van de door hem ontworpen pen het indicatiegebied uit te breiden. De ontwikkeling van flexibele boren door Pohl makkte het mogelijk de mergholte op te boren en zo een dikkere pen te introduceren, hetgeen de stabiliteit ten goede kwam. Küntscher's pen had op dwarsdoorsnede een klaverbladprotiel, dat heden ten dage nog gebruikt wordt (afbeelding 17).

Het idee om met een pen proximale en distale, maar ook etage- en meerfragmentfracturen te stabiliseren, bleef Küntscher fascineren en tot zijn dood heeft hij gewerkt aan de oplossing van dit probleem. In 1940 introduceerde hij de $\mathrm{Y}$-pen voor fracturen in het trochantergebied (afbeelding 18 a en b), warop Zickel later zijn pen baseerde (1980). In 1945 ontwikkelde hij samen met Maatzeen methode om femurschachtfracturen met sterke verbrijzeling te stabiliseren. In de gleuf van de pen werd op de plats van de verbrijzeling een dun, dubbelgevouwen stuk metaal ingebracht dat de hoofdragmenten op lengte diende te houden en tevens de wondranden open hield om voor voldoende drainage te zorgen (albeelding 19). Deze tech- 

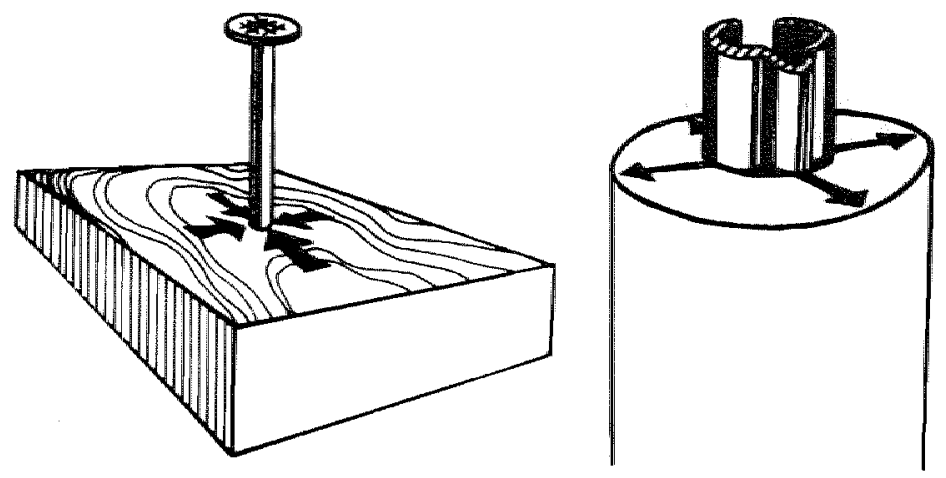

Ah. 17 Deze tekening geeft alan dat de manier watrop een spijker klemt in cen blok hou provies

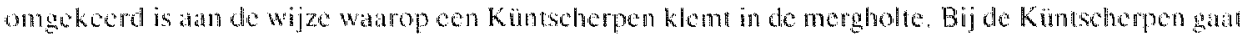
we inklemming wit van de samengedrukte pen en bij de spijker van het samengeperste houl.

(Lit: Kuntscher 1945).
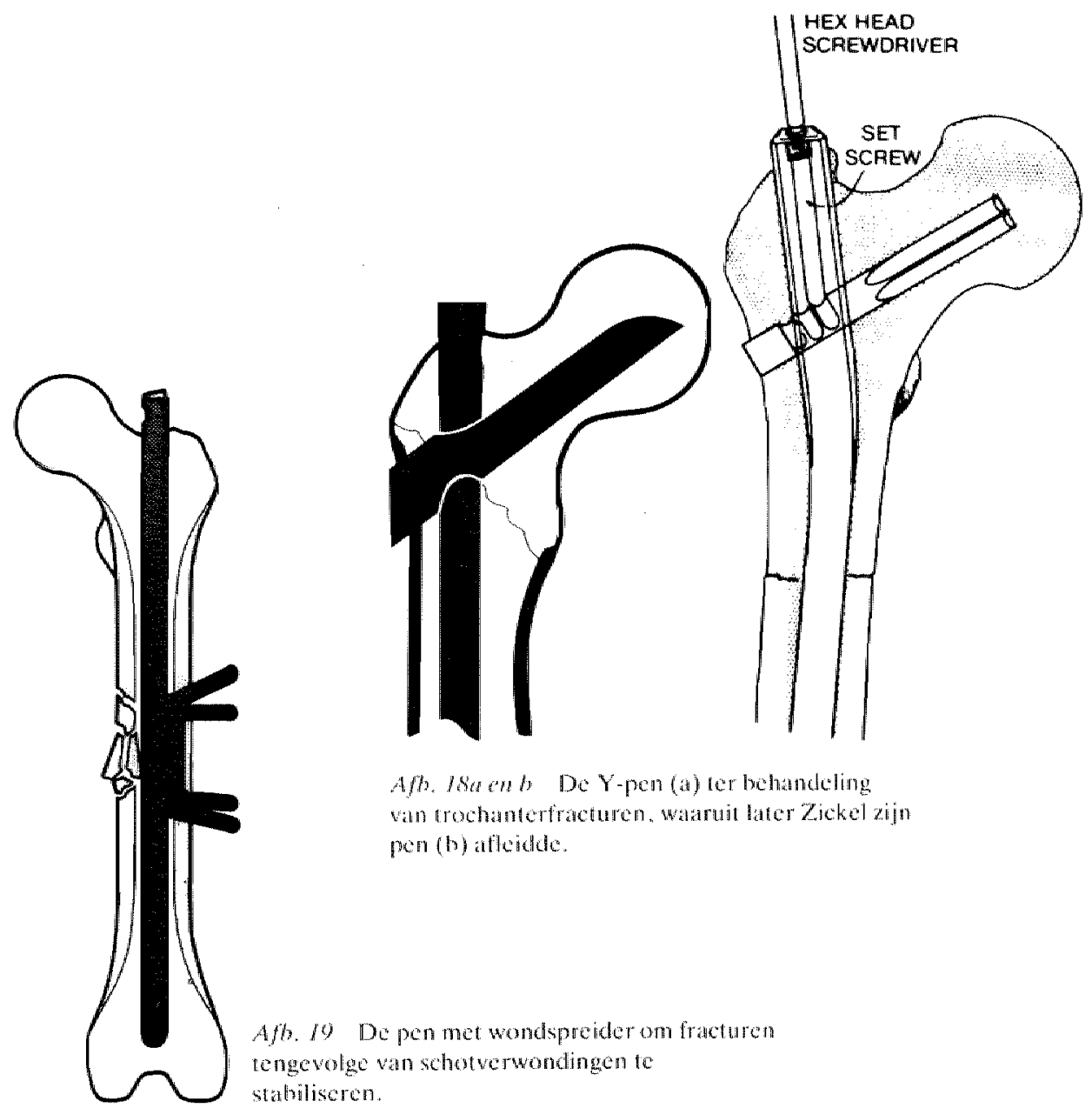

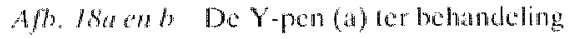
van trochanterfacturen. Watant later Zickel zijn por (h) afloidde.

Afb. 10 De pen met wondspreider om fracturen tengevolge van schotverwondingen te stabiliseren. 
niek werd in de latste jaren van de Tweede Wereldoorlog speciaal ontworpen om fracturen ten gevolge van schotverwondingen te behandelen.

Herzog presenteerde in 1950 zijn publicatie "Verlängerungsosteotomie unter Verwendung des percutan gezielt verriegelten Marknagels" (afbeelding 20). Bij deze techniek werd een van diverse boorgaten voorziene Küntscherpen percutaan met meerder Kirschnerdraden wergrendeld. Door de talrijke boorgaten werd de pen te zeer verzwakt. Ook de vergrendeling was technisch niet eenvoudig en de dunne draden boden te weinig stabiliteit.

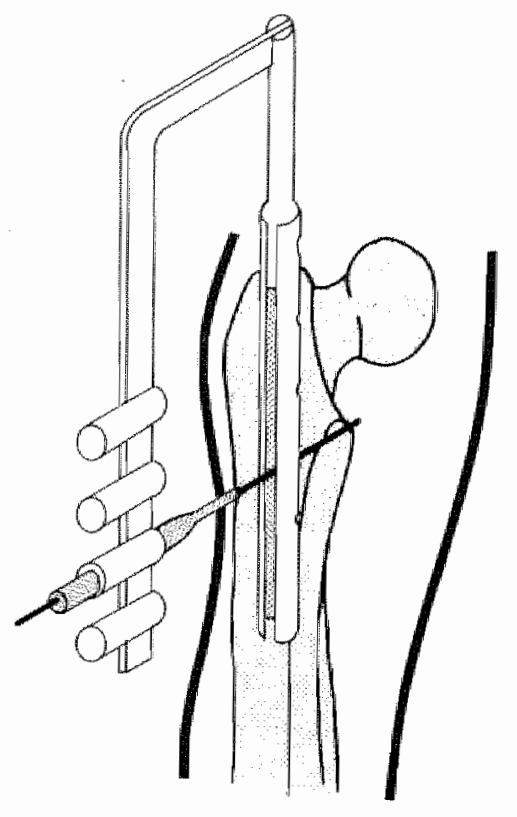

Af). 20 Percitane vergundeling met meerdero

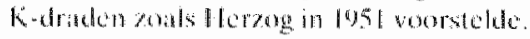

Kuntscher publiceerde in 1960 zijn techniek om meerfragmentracturen met over elkaar geschoven pennen van verschillende lengte en diameter te stabiliseren (afbeelding 21). Deze techniek is nooit boven het experimentele stadium uitgekomen. Het zogenaamde "Distanzblock" werd door hem in 1965 gelanceend. Het idee was eigenlifk hetzellde als bij de pen met wondspreider. Met het "Distanzblock" (afbeelding 22) werd het op lengte houden van beide hoofdragmenten via een gesloten methode bereikt. Nadat de voerdrad was ingebracht, werd een metalen strip intramedullair gebracht. Op deze strip bevond zich een metalen wig, net zo lang als het botdefect. Deze wig werd tussen de beide hoofdragmenten gemanoeuvreerd, zodat de fractuur niet kon inzakken. Hierna werd de pen ingebracht die de wig op zijn plaats hield. De metalen strip was op dwarsdoorsnede licht gekromd, zodat hij goed om de pen paste. Het was mogelijk pen en strip gesloten te verwijderen na consolidatie van de fractuur. Deze metaalstrippen met een wig van variabele grootte zijn nog in productie genomen, mar ook deze methode is geen succes geworden. In 1968 hield Küntscher op het chirurgencongres in München een voordracht genaand "Die Marknagelung des Trümmerbruches" (afbeelding 23). Hierin be- 


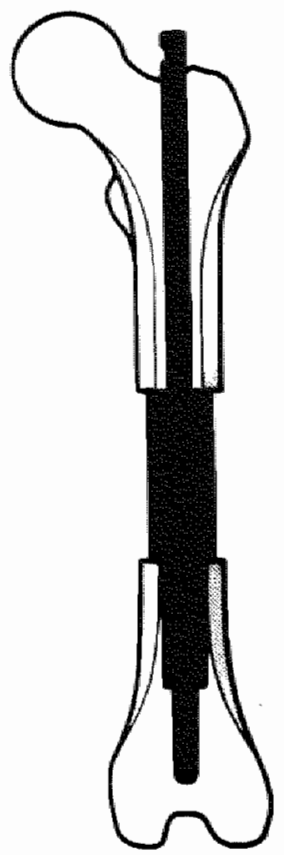

Afb. 21 Mecrdere Kürstscherpennen wan verschillende longte en diameter dic over clkar geschoven werden om de hootdragmenten op afstand to houden.

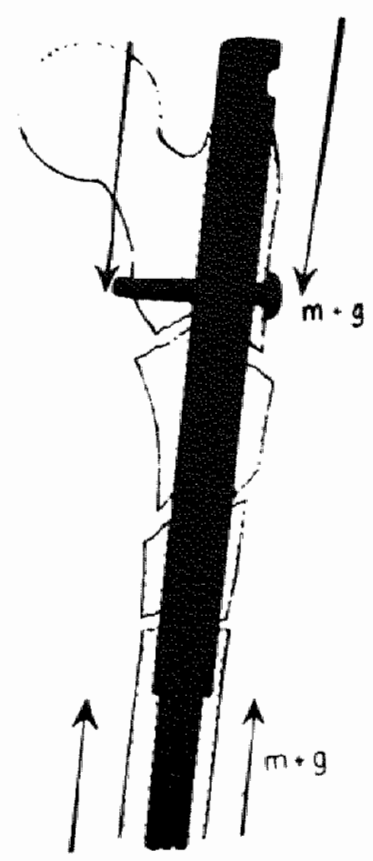

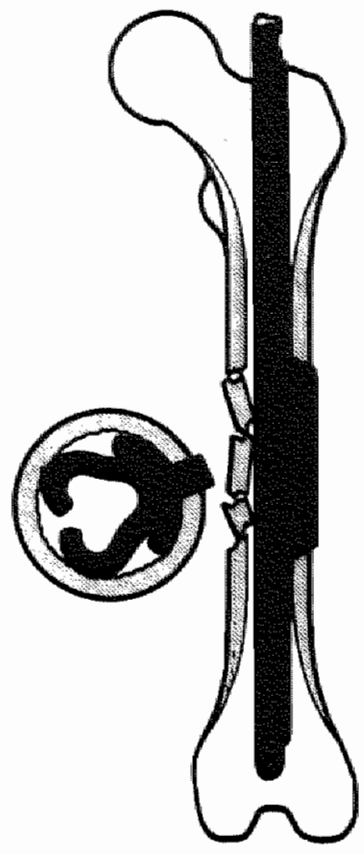

Afo. 22 Künesherpen nue "Distanzblack".

Afb. 23 "Detensionsnagel" natar Küntscher.

(Uit: Kuntseher 1968 ). 
schreef hij de toepassing van een pen, die via schroeven proximaal en distaal aan de femurschacht bevestigd werd. Hif noemde deze techniek zelf "Detensionsnagelung" en gaf de pen de naam "Detensor". Het principe beschreef hij als volgt: "Es ist das Verfahren der Detension, das Ferwhalten aller Kräfte aus dem Buchspalt, die Entspannung".

Klemm en Schelimann namen naar aanleiding van Küntscher's publicatie over de "Detensor" in 1970 contact op mel Küntscher. Gedurende de jaren 1970-1972 ontwikkelden zij de pen verder en on wierpen instrumentarium ter introductie, extractie en vergrendeling van de pen. Tevens werd de pen klinisch getest. De belangstelling van Klemmen Schellmann woor de "Detensor" kwam voort uit het feit, dat zij op zoek waren naar een geschikte methode om (geinfecteerde) pseudarthrosen te behandelen. Na afsluiting van het ontwikkelingswerk en na een eerste klinische toepassing bij 51 patiënten in de Berufsgenossenschaftiche Unfallklinik te Frankfort werd de Grendelpen voor het femur vanaf 1972 seriematig geproduceerd (Ortopedia). In datzelfde jaar werd met toestemming van Küntscher de naam veranderd in "Verriegelungsnagel".

Tijdens de testperiode was gebleken, dat één distale schroef ter vergrendeling te weinig was. Derhalve werd een distale vergrendeling met 2 schroeven ingevoerd. Door de proximale schroef schusin in plaats van dwars in te brengen. kon ook proximaal de verankering verstevigd worden. Ook de schroeven werden aangepast. In het begin werden bouten zonder schroefdraad gebruikt, die vaak loslieten. Door deze bouten te voorzien van een eindstandige zelftappende schroefdraad kon dit euvel grotendeek worden opgeheven.

Grosse en Kempl vervolmakkten in de jaren 1972-1977 hel osteosynthesesysteem (Howmedica "). Er zijn duidelijke verschillen tussen beide systemen die in hoofdstuk 6.5. ter sprake komen.

In 1977 werd door Lafforgue en Grosse en richtapparaat voor de distale vergrendeling ontworpen. Dit richtapparat kan op de C-boog van de beeldversterker worden gemonteerd, waarna men onder röntgencontrole de distale vergrendeling kan uitvoeren.

Al deze technische verbetcringen droegen er essentiè toe bij om de ingreep "Verriegelungsnagelung" routinematig volgens vast protocol toe te passen.

\subsection{Biomechanische eigenschappen}

Een conventionele mergpen fungeert voomamelijk als stabilisatlor doordat zij de botcylinder als krachtdragend element herstelt. De pen verhindert dat de hoofdfrangmenten zijdelings ten opzichte van elkaar verschuiven. Door het verhaken van de fragmenten en door de spierspanning wordt de osteosynthese enigszins tegen rolaticafwijkingen beschermt. Sedert de uiteenzettingen van Küntscher beschouwt men de elastische inklemming van de pen in de mergholte en de driepuntsfixatie in de lengterichting van de lemurschacht als de werkingsprincipes wat betreft de stabiliteit (Küntscher 1962). Doordat de pen in de lengterichting enigszins kan buigen en in dwarse richting vervormbatr is, ontstat er met de binnenzijde van de botcylinder over een groot oppervlak wrijying. Rehm toonde aan dat naarmate het contactoppervlak groter is, de wrijwing tussen pen en corticalis toeneemt, hetgeen een ver- 
betering van de stabiliteit met name tegen torsiebelasting geeft (Rehm 1963).

De stijfheid van de pen (de eigenschap van de pen om buigkrachten te weerstann) neemt toe naarmate de pendiameter toeneemt. Een zekere stijfheid van de pen is nodig, wil de patiënt na de operatie zijn been kumnen bewegen of gedeeltelijk belasten zonder dat de pen vervormt of breekt. Een pen moet ook een bepalde elastische vervormbaarheid bezitten om bij het inslaan van de pen geen problemen te krijgen (spildraai). Bij het ontwerpen van een pen moet men als het ware een compromis sluiten tussen stijheid en elasticiteit van de pen (Brussatis 1975).

Het blijkt uit door Vècsej (1983) verricht onderzok dat het door Küntscher gekozen klaverbladprofiel de grootste buigmomenten kan weerstan (tabel 1).

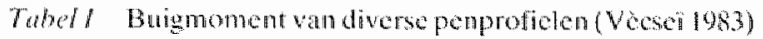

Buigmoment plistische

vervorming (Nm)

$\begin{array}{ll}\text { Klaverbladprofict met gleuf (pendiame ter } 11 \mathrm{~mm} \text { ) } & 56,3 \\ \text { Buisprofici (pendiameter } 11 \mathrm{~mm} \text { ) } & 37 \\ \text { Klaverbladproficl zonder gleuf (pendianeter } 11 \mathrm{~mm} \text { ) } & 53\end{array}$

Met betrekking tot de weerstand tegen torsiebelasting blijkt een buisprofiel de meeste stijfheid te bezitten, gevolgd door een klaverbladprofiel zonder gleuf (tabel 2).

Tohel? Torsicmoment van diverse penprofielen (Vecseï 19k3)

Torsiemonent plastische vervorming $(\mathrm{Nm})$

Kaverbladprofel met gleuf (pendiameter $11 \mathrm{~mm}$ ) 7

Wang (1981) verrichtte experimenteel onderzoek bij gefractureende komijnenlemora met rigide en elastische mergpennen. Hel bleek dal zowel excessieve stijtheid als overmatige elasticiteit een optimale fracturgenezing verhinderen.

Het principe wan de dwarse, elastische inklemming van een pen in de mergholte is discutabel. Küntscher (1962) en Burny (1971) hechtten hier veel watarde aan, terwijl Kempe (1978) aantoonde, dat de rotatiestabiliteit na Küntscherpenosteosynthese slecht is en het opboren van de mergholte om een pen met een grotere diameter te kunnen inbrengen de rotatiestabiliteit alleen mar verslechtert. De meest wezenlijke fixatie van de mergpen is de driepuntsfixatie in de lenglerichting van de schacht, welke ontstaat wanneer men een rechte buis in een gebogen mergkanaal slaat (Kempf 1978).

De beperkte toepasbarheid is het probleem van de conventionele mergpen.

Stapert (1983) heeft aangetoond dat met de Küntscherpen slechts $50 \%$ van alle femurschachtfracturen behandeld kumen worden, vooral de dwarse en korte schuine fracturen in het gebied van de potentiële isthmus (Lemmens 1981). Bij meerfragmentracturen geeft een Küntscherpen een zekere lengtestabiliteit mar geen 
torsiestabiliteit. De Grendelpengarandeert bij alle fracturvormen lengte-en rotatiestabiliteit. Door het gebruik van schroeven die de pen aan de botcylinder verankeren, moet het osteosynthesemateriaal alle axiale lasten opvangen en overbrengen totdat de fractuur geconsolideerd is, terwijl bij een conventionele mergpen het bot zelf vrijwel alle axiale krachten opvangt. Bij een statische vergrendeling wordt het gedeelte van de botcylinder tussen de schroeven mechanisch volledig geneutraliseerd (Hudec 1977).

Kempf (1978) en Vècsei (1983) hebben de belastbaarheid van een statisch vergrendelde pen onderzocht. Wanneer een groot gedeelte van de schacht tussen de schroeven ontbreekt, dient het osteosynthesemateriaal alle krachten op te vangen. Deze situatic is vergelijkbaar met een femurfractuur met uitgebreide verbrijzeling van de schacht. Onder deze omstandigheden is de torsiestabiliteit van een conventionele pen $420 \mathrm{Ncm}$, bij een dynamische vergrendeling $780 \mathrm{Ncm}$ en bij een statische vergrendeling $1560 \mathrm{Ncm}$ (Kempf 1978). Bij een statisch vergrendelde pen is de torsiestabiliteit ten opzichte van een Küntscherpen bijna vier maal zo groot.

Wat betreft de buigbelasting heeft Diehl (1976) berekend dat bij een axiale belasting van $10 \mathrm{~kg}$ de buigbelasting van de femurschacht van proximaal naar distaal $1200-200 \mathrm{Ncm}$ bedraagt. Bij optillen van het been in narcose is de buigbelasting $3600-2500 \mathrm{Ncm}$ en bij volledig belast lopen ( $80 \mathrm{~N}$ ) bedraagt de buigbelasting op het midden van de femurschacht $4000 \mathrm{Ncm}$. Kempf (1978) toonde experimenteel aan dat bij een statisch vergrendeld femur, waarbij het middelste deel van de schacht ontbreekt, een buigmoment van ongeveer $2000 \mathrm{Ncm}$ het complex pen-bot zijn integriteit zal doen verliezen.

Dit betekent voor de praktijk dat bij een meerfragmentfractuur die door een statisch vergrendelde pen is gestabiliseerd, een belasting van het been van $10-20 \mathrm{~kg} \mathrm{di}-$ rect postoperatief geen enkel probleem vormt maar dat een volledige belasting uiteindelijk zal leiden tot penbreuk.

\subsection{Het indicatiegebied}

Het beperkte indicatiegebied van de Küntscherpen is voomamelijk te wijten aan het leil, dat de pen in vele gevallen onvoldoende klemt in de mergholte, omdat door de kromming van het lemur en de wisselende mergholte diameters ook na het opboren de pen maar over een klein traject voldoende circulaire elastische inklemming heeft. Wanneer men op een slechte indicatie toch een Küntscherpenosteosynthese verricht, leidt dit automatisch tot een slecht resultat. Dit gegeven en het feit dat met een plaatosteosynthese alle lemurschach fracturen behandeld kunnen worden, heeft geleid tot een sterke toeneming van het aantal plaatosteosynthesen bij femurschachtfracturen.

De Grendelpen biedt de mogelijkheid on femurfracturen, die niet geschikt zijn om volgens het Küntscherprincipe te behandelen, zoals proximale, distale en comminutieve fracturen, toch te stabiliseren met een intramedullaire osteosynthese. De proximale en distale schroeven, warmee de pen aan het bot wordt verankerd, bieden hiertoe de extra stabiliteit. De Grendelpen biedt de voordelen van een mergpen, terwijl met deze osteosynthesevorm het hele indicatiegebied van de platosteosynthese bestreken wordt. Door de axiale krachtoverbrenging is een vroege belasting mogelijk. Bij de gesloten operatietechniek hoeft het fractuargebied tijdens 
de operatio niet vrijgelegd te worden, zoals bijeen plaatosteosynthese. Door het inbrengen van de schroeven wordt de fractuur op lengte gehouden en neemt de 10 r- $^{-}$ siestabiliteit toe.

In hoofdstuk 2 werd aangegeven, dat fracturen vanaf de trochanter minor $10 t 6 \mathrm{~cm}$ boven de kniespleet met de Grendelpen behandeld kunnen worden. De Grendelpen is eveneens geschikt om pseudarthrosen en pathologische fracturen te behandelen, om arthrodesen van de knie te verrichten (afbeelding 24 ) en om comigerende osteotomiën te stabiliseren (afbeelding 25).

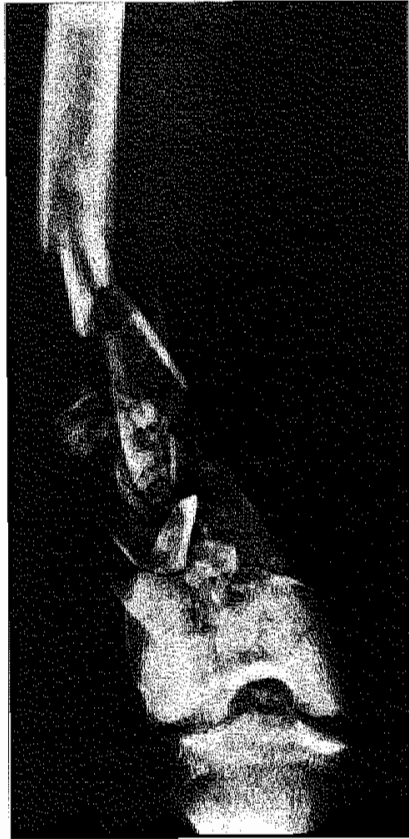

a

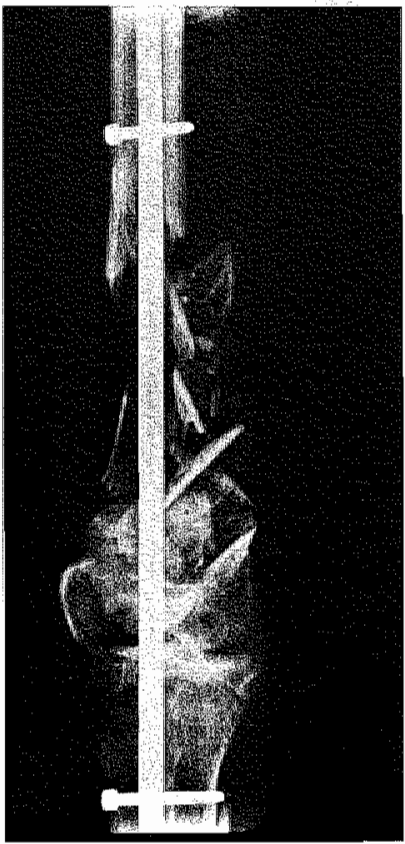

H.

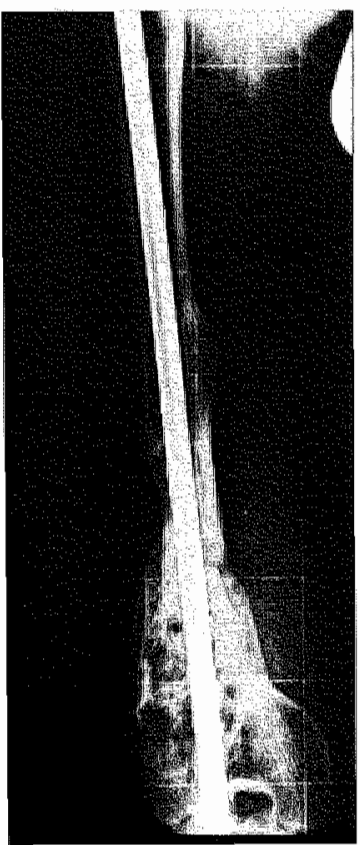

$c$

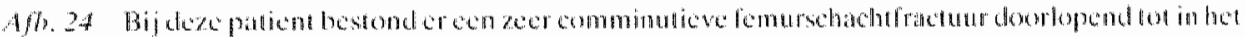
whilentalak.

A. Ronterolonabijopname.

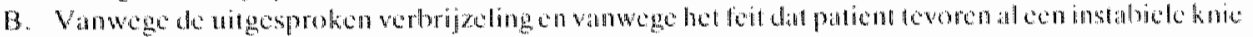
hat. Werd primatr en arthodese vin de knic verrich .

C. Rongunfoto zever jas lat de operatio.

Bij proximale of distale fracturen kan een eenzijdige vergrendeling voldoende zijn (afbeelding 26). Dit wordt een dynamische vergrendeling genoemd. Door belasting wordt het instuiken wan de fractuurstukken bewerkstelligd, waardoor ecn zeer sne le fractururgenezing optreedt. Een dynamische vergrendeling is alleen mogelijk bij enkelwoudige, dwarse fracturen ewentueel met een "Biegungskeil". Deze fracturen zijn in de regel postoperatiel volledig belastbaar. Wanneer men een éenzijdige vergrendeling wiltoepassen, dient men nawkeurig te letten op de vorm en de locallisatie van de isthmus van de mergholte, omdat de pen aan de kant war zij niet vergrendeld wordt, een goede inklemming volgens het Küntscherprincipe dient te heb. ben. 

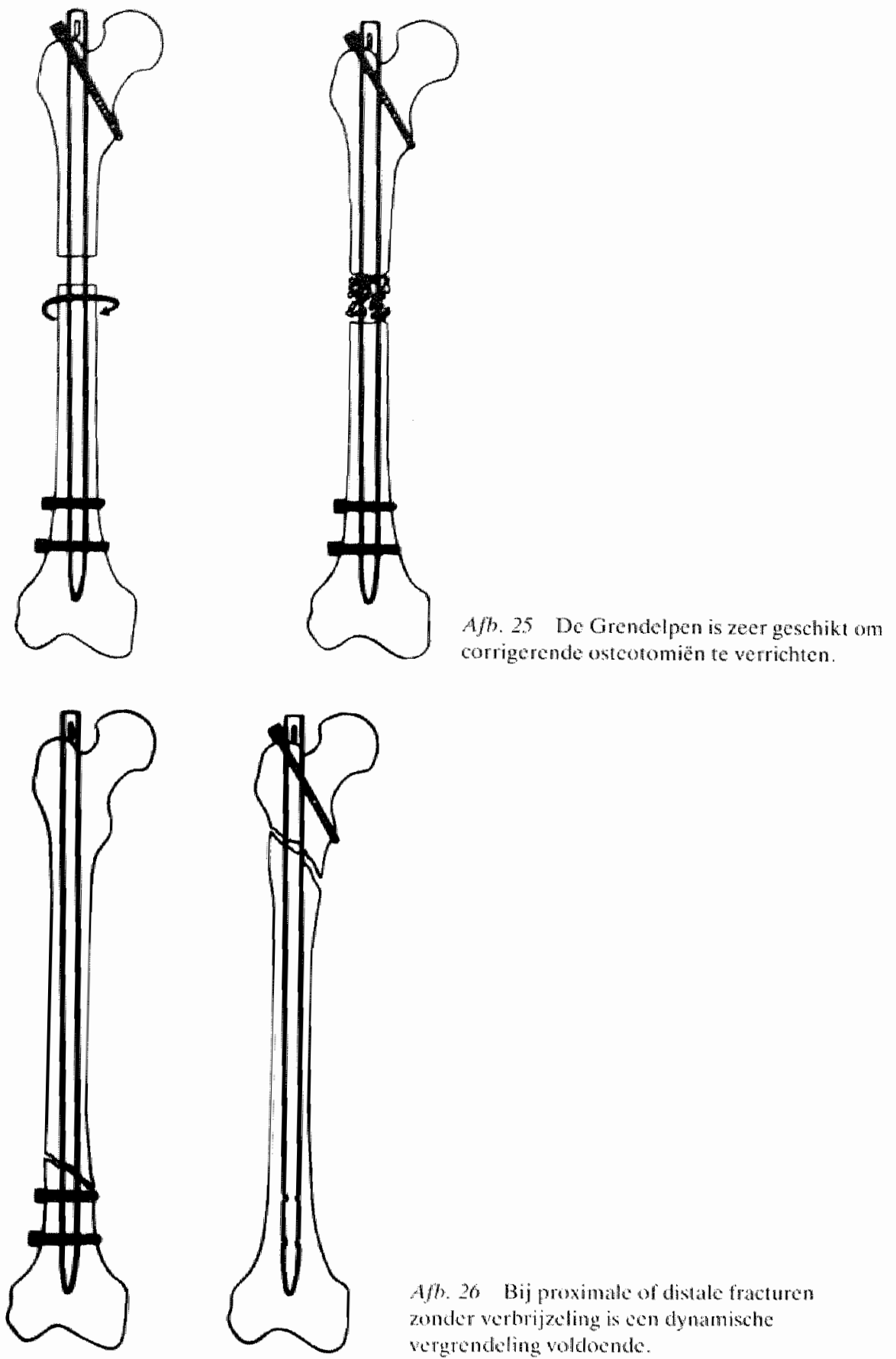
Afb, 26 Bij proximatle of distale fracturem zonder verthrijzeling is cen dynamische vergrendeling voldoends.

Bij schuine of spiraaltracturen en bij meerfragmentfracturen dient de pen aan beide kanten vergrendeld te worden: de zogenaamde statische vergrendeling. Bij statisch vergrendelde fracturen dient het verwijderen van de vergrendeling aan éen kant van de pen bij de eerste callusvorming plaats te vinden om door drukbelasting van 

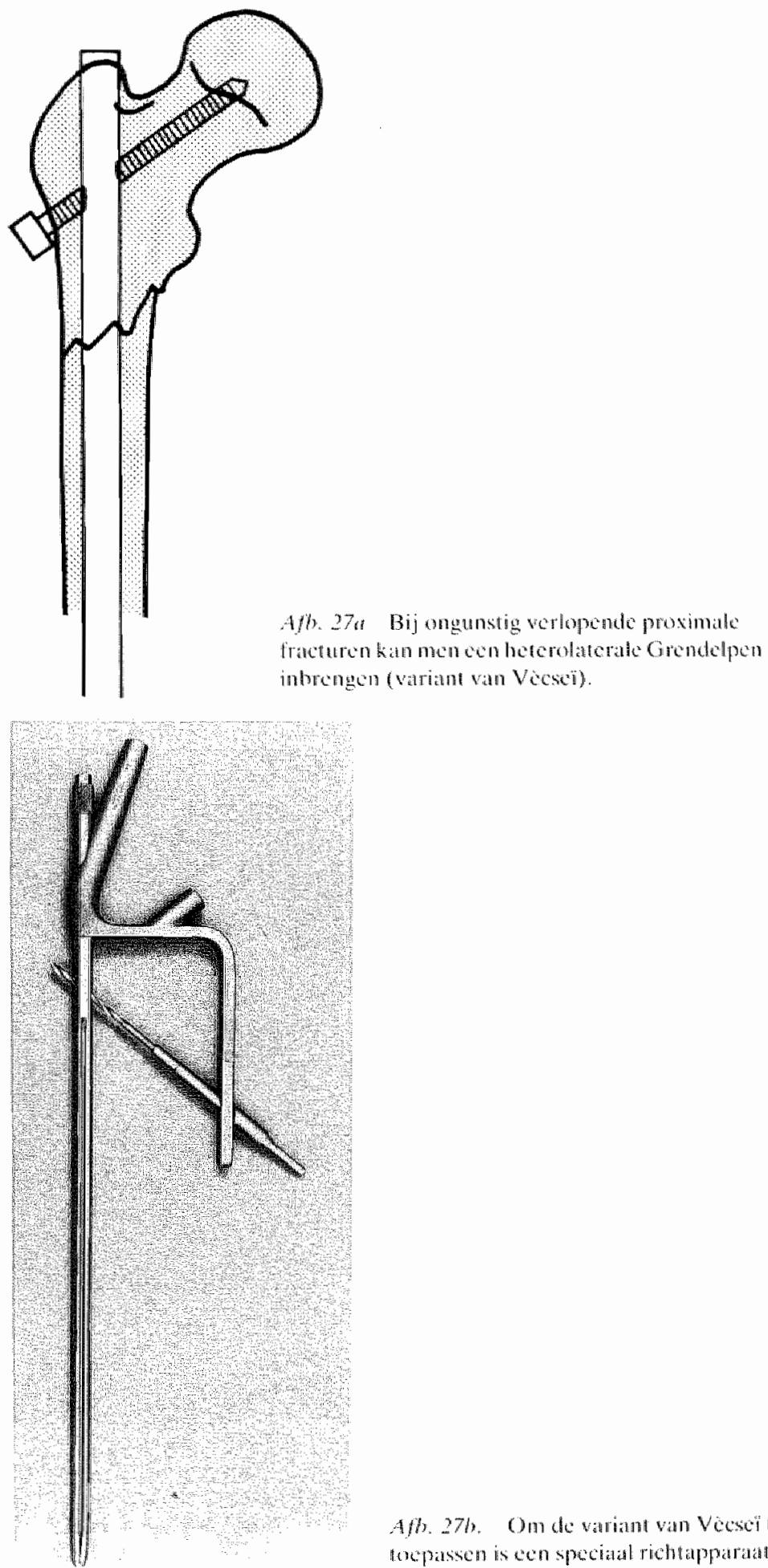

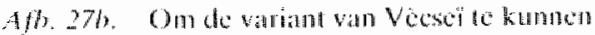
foepassen is ecen speciatich richaparatat noodzalkellik. 
de fractuur de botgenezing te stimuleren. Vaste regels voor dit zogenaande dynamiseren zijn nief te geven. Men dient voor wat betreft de callusvorming op de röntgenfoto af te gaan. Bij een ongecompliceend verloop kan de osteosynthese meestal na 2 a 3 maanden gedynamiscerd worden. De schroeven dienen in principe aan die kant verwijderd te worden, war de pen over een lang traject een goede botgeleiding heeft. Dat betekent dat men bij een distale fractuur de proximale schroef verwijdert en bij een proximale fractuur de distale schroeven (Mock witz 1983).

Er bestaan een aantal "grensindicaties" voor de toepassing van een Grendelpenosteosynthese.

Bij ongunstig verlopende proximale femurschachtfracturen, waarbij de trochanter minor gefractureerd is, maar de laterale cortex intact is, kan soms een variant worden toegepast, die door Vècseï (1978) werd beschreven. Door in plats van een rechter een linker Grendelpen (heterolaterale Grendelpen) te nemen, loopt de proximale schroef schuin omhoog in de richting van de dijbeenhals, in plaats vam schuin omlaag in de richting van de trochanter minor (afbeelding $27 \mathrm{a}$ ). Om de schroef te kunnen introduceren is een speciaal richtapparaat nodig (afbeelding 27b).

Sporadisch komt een femurschachtfractuur voor in combinatie met een dijbeenhalsfractuur of een pertrochantere femurfractuur. Wanneer men de techniek van de Grendelpenosteosynthese beheerst, is het mogelijk om bij cleze combinatie van fracturen toch een Grendelpenosteosynthese uit te voeren door eerst de dijbeen-
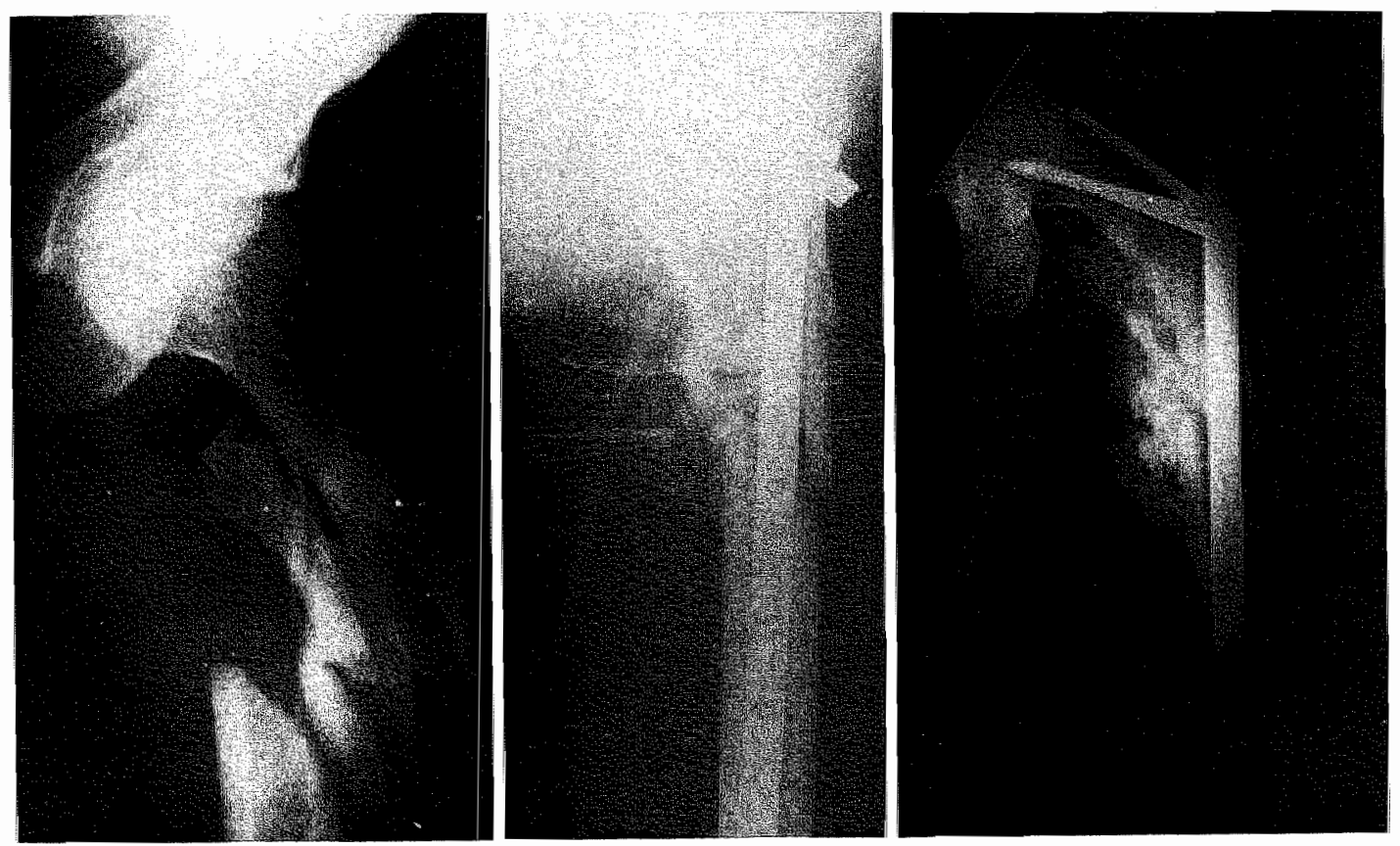

Alb. 3 .

a. Combinatio watn cen proximale femnutractun en con lateralle collumfractum.

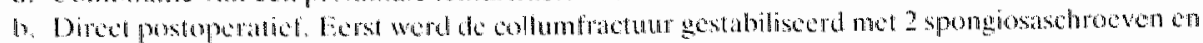
datima ward ale Grendelpon tusien beide schroeven ingebrach.

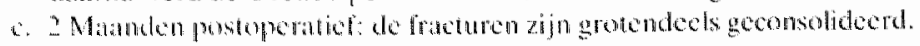


halsfractuur te fixeren met twee spongiosaschroeven en darana tussen beide schroeven door de Grendelpen te introduceren (afbeelding 28). Soms bestar er een fractuur van het condylenblok in combinatie met een femurschachtractutr. Wanneer dit een relatief eenvoudige fractuur is, dan is het een elegante oplossing om eerst de fractuur van het condylenblok met spongiosaschroeven te fixeren en daarna de schachtfractuur van een Grendelpenosteosynthese te voorzien. Een Grendelpenosteosynthese aangevuld met enkele spongiosaschroeven is zeker de minst ingrijpende vorm van osteosynthese voor dergelijke "combinatie" -fracturen. De vroege belastbaarheid van de extremiteit is het grote voordeel van een Grendelpenosteosynthese bij proximale, distale, meerfragment-en etagefracturen. Bovendien is de operatietechniek eenvoudiger en minder traumatiserend dan bijvoorbeeld een hoekplaatosteosynthese.

\subsection{Open versus gesloten operatietechniek}

Bij het thema penosteosynthese komt automatisch de vraag naar voren of de open dan wel de gesloten operatietechniek te prefereren is. Deze discussie wond al vanal de invoering van de Küntscherpen gevoend (Wittmoser 1955, Küntscher 1967. Zimmermann 1967. Marty 1969, Baltersweiler 1975, Kuderna 1975, Wenninger 1975, Bäuerle 1976, Galle 1981). Aan de hand van de literatuur kan men voor-en nadelen wa beide methoden tegenover elkararzetten (tabel 3 en 4 ).

Tabel 3

\section{Voordelen gesloten techniek}

1. Behoud wan het fractuurhaematoom (?) en boormeel (?).

2. Geer deperiostering.

3. Relatief kleive incisie ver vande fractur (beter cosmetisch resultagt)

4. Minder infoctios.

5. Geringer bloedverlies (?)

6. Kortere operatlietijd(?).

7. Nawkentige bepalling wande penlengto mogelijk.

\section{Nadelen gesloten techniek}

1. Extensietafel co beeldversterker noodrakelijk.

2. Repositie moxilijker en soms onnawweutrig

3. Meer rotateafwijkingen en vaker distractie van de fractuut.

4. Tengevolge van de hulpmiddelen loopl de steriluteit gevertr.

5. Röntgomsuralco belasting.

6. Kans op uitbreken ven fragnenten.

Tabed 4

Voordelen open techniet

1. Nomalc operatietatel woldoende.

2. Gombendwerserker moodzakelijk.

3. Repositio envoudigenexat.

4. Geengerata voor rotatie- of distructuatulukingen

5. Mogelijkheid tot uitspoelenvanhes fracturhaematoom en het boomed (?).

\section{Nadelen open techniek}

1. Twee incisios noodrokelijk.

2. Afschuiven van het periost.

3. Langere openatuefigl(?).

4. Slechter cosmenseh resiltant

5. Meerinfectics.

6. Lengle van de pera moet proporatiot bepaald worden. 
Het feil dat bij de gesloten operatietechniek slechts één kleine incisie noodzakelijk is, spreekt voor zich. Dat hierdoor een fraaier cosmetisch resultaat verkregen wordt, is evident. Of het antal infecties hierdoor wordt verminderd, is altijd het grote punt van discussie geweest. Maatz (1983) beantwoordde deze vraag. Hij onderzocht retrospectief 1.996 femurfracturen waarbij volgens vast protocol de gesloten operatietechniek was toegepast en 1.968 fracturen waarbij de pen volgens pro$10 \mathrm{col}$ via de open techniek werd ingebracht. Alleen gesloten fracturen werden in het onderzoek opgenomen. Het infectiepercentage was in beide groepen respectievelijk $13,65 \%$ en $3,4 \%$. Met andere woorden: bij een via de open operatietechniek ingebrachte femurpen is de infectiekans 5 maal zo groot.

De gesloten operatietechniek is afhankelijk van technische hulpmiddelen, zoals een extensietafel en röntgenfaciliteiten. Het gebruik van de beeldversterker heeft als voordeel, dat men peroperatief exact de lengte van de pen kan bepalen. Anders moet men de lengte van de pen vooraf bepalen door een röntgenfoto van het andere femur te laten maken met darop een centimeterverdeling. Dupuis (1977, 1978, 1983). Ewen (1974, 1976) en Fischer (1973) hebben zich intensief bezig gehouden met het meten van de stralenbelasting van patient en operatieteam bij het gebruik van de beeldversterker. De stralenbelasting blijkt zeer gering te zijn. Dupuis mat bij een doorlichtingstijd van 7 minuten op $80 \mathrm{~cm}$ van de stralengang een belasting van $2 \mathrm{mRad}$. De gemiddelde stralenbelasting van de operateur gedurende 1 minuut doorlichting bedroeg boven de loodschort (hoofd, hals en armen) $4,2 \mathrm{mRad}$ en onder de loodschort (dikte $0,5 \mathrm{~mm}$ ) $0 \mathrm{~m}$ Rad.

Volgens het veiligheidsbeshit ioniserende straling (1963) is de maximale bestralingsdosis voor radiologische werkers 60 Rem per jaar voor wat betreft handen, onderarmen, voeten en enkels en 5 Rem per jaar voor wat betreft de ooglens. Dit komt ongeveer overeen met resprectievelijk $60.000 \mathrm{mRad}$ en $5.000 \mathrm{mRad}$ per jaar, indien we ervan uitgaan dat bij het gebruik van röntgenstraling I Rem vergelijkbaar is mel 1 Rad. De gemiddelde doorlichtingstijd voor het inbrengen van de Grendelpen bij een femurfractur bedroeg in de kliniek van Kempt in Straatsburg 3'43". Men dient te bedenken, dat dit een opleidingskliniek is. Door ervaren chirurgen kan deze tijd worden bekort. Het gebruik van een beeldscherm met een geheugen kan de doorlichtingstijd nog eens met $60 \%$ verminderen.

Het veelvuldig optreden van rotatieafwijkingen bij de gesloten operatietechniek wordt door tegenstanders van deze techniek naar voren gebracht. Men dient te beseflen, dat geringe $\left(<20^{\circ}\right)$ rotatieafwijkingen klinisch moeilijk vast te stellen zijn, ondat de patient cleze in het heupgewricht corrigeert. Door het vergelijken van de rotatiemogelijkheid van beide benen kan men wel enigszins een indruk krijgen omtrent een eventuele rotatieafwijking van het femur, maar geringe afwijkingen komen hierbij niet aan het licht. Exacte informatie wordt verkregen wanneer een röntgenopname van het bekken gemaakt wordt volgens Dunn-Rippstein (Dumn 1952. Rippstein 1955. Jäger 1973). Hierbij wordt een opname van het bekken gemakk met de patiënt in rugligging, beide bovenbenen $20^{\circ}$ geabduceerd, heup- en kniegewricht $90^{\circ}$ gebogen en beide onderbenen parallel aan het bovenlichaam. Op deze manicr kan de geprojecteerde anteversie van beide femora berekend en met elkatur vergeleken worden. De nauwkeurigheid van deze meetmethode is ongeveer $5^{\circ}$ (Wolf 1984$)$. 
Na fracturen zijn rotatieafwijkingen van het femur vrijwel altijd exorotatieafwijkingen. Afwijkingen groter dan $20^{\circ}$ zijn klinisch zichtbar omdat een dergelijke afwijking niet bijiedere stap door de endorotatoren te corrigeren is.

De literatuur geeft de volgende informatie omtrent het voorkomen van rotatieafwijkingen bij beide operatietechnieken (de afwijkingen werden aan de hand van klinisch onderzoek vastgesteld) (tabel 5 en 6 ):

Tabels Femurfacturen warbij de pen via de gestoten operat ietechniek werd ingebracth

\begin{tabular}{|c|c|c|}
\hline Clawson (1071) & $46 \mathrm{gevallon}$ & 0 rotatioafwijkingen \\
\hline Brussatis $(1975)$ & 174 gevallen & $9 \quad \cdots$ \\
\hline Rothwell (1978) & longevallen & $*$ \\
\hline
\end{tabular}

Totaal

320 gevallen

16 rotatienfwijkingen

(5\%)

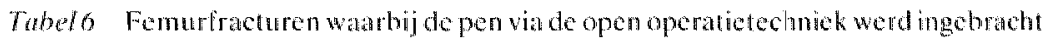

\begin{tabular}{|c|c|c|}
\hline Wambrod (1976) & 236 gevallen & Drotitionfwijkingen \\
\hline $160 j o r(1978)$ & 100 gevallen & 1 \\
\hline Mutar(1976) & 72 gewallen & 0 \\
\hline Totaal & 408 gevallen & $\begin{array}{l}1 \text { rotatieafwijking } \\
(0,29)\end{array}$ \\
\hline
\end{tabular}

De kans op rotatieafwijkingen is bij de gesloten operatietechniek 25 maal zo groot. Als voornaamste oorzaken ziet men het ontbreken van een driepuntsfixatie of het onvoldoende klemmen in de mergholte ten gevolge van een foutieve techniek of een verkeerde inclicatiestelling. Een andere oorzaak is het feit, dat de meeste pennen in zijligging worden ingebracht, waarbij geen exacte vergelijking van beide benen met betrekking tot rotatieafwijkingen mogelijk is. Wanneer men de Grendelpen inbrengt met de pattiënt in rugligging en beide benen gestrekt op de rektafel. dan is er een vrij nauwkeurige controle op rotatiealwijkingen mogelijk.

Bovendien heeft een Grendelpen een veel grotere torsiestabiliteit zodat hel secundair optreden van rotatieafwijkingen, zoals bij een te dunne Kïntscherpen wel werd gezien. is uitgesloten.

Over het optreden van rotatieatwijkingen bij Grendelpenosteosynthesen van het femur zijn nog erg weinig gegevens bekend. In de series die tot nu toe gepubliceerd werden en warbij de Grendelpen vrijwel uitsluitend via de gesloten operatietechniek werd ingebracht, was het percentage erg laag en varieerde van $0-2 \%$

(Mommsen 1983, 42 fracturen; Börner 1983, 103 fracturen; Maroske 1983, 131 fracturen: Trojan 1983,27 fracturen).

Bij de open operatietechniek is de repositie makkelijker en kan op de millimeter nauwkeurig geschieden. Een dusdanig perfecte repositie, die bijeen plaatosteosynthese van wezenlijk belang is voor de stabiliteit, is bij een Grendelpen niet belangrijk: als er maat voldoende rust heerst in het fractuurgebied.

Of er atan thet fractuurhaematoom en het boormeel een osteogenetische potentic moet worden toegekend, is niet duidelijk. Voorstanders van de gesloten operatietechniek menen van wel. Schötle (1978) berekende dat wanneer het femur van een 
volwassene wordt opgeboord van 9 tot $15 \mathrm{~mm}$ er ter plaatse van de fractuur $7,3 \mathrm{~g}$ boormeel uitreedt en ter plaatse van de trochanter major $5,1 \mathrm{~g}$. Hij stelde dat de osteocyten, ook al zijn zij door de hitte-inwerking beschadigd of dood, een osteogenetische potentic bezitten. Hij adviseerde dan ook om de mergholte na het opboren te spoeten me $20-40 \mathrm{~m}$ l Ringeroplossing en tijdens dit spoelen de opening in de trochanter major af te dichten, zodat zoveel mogelijk boormeel in her fractuurhaematoom terecht komt om van daartit ean gunstige invloed op de botgenezing wit re oefenen. De tegenstanders beschouwen het haematoom en het boomeel als een voedingsbodem voor bacterièn.

In hoofdstuk 5 werd uitgelegd warom de open operatietechniek en het daarmee geparard gaande additionele letsel van weke deten en periost een nadelige factor vormon woor de fracturgenezing met name bijmeerframentfracturen.

Baüer (1976) stelde dat bij de gesloten operatietechniek het bloedverlies minder is. Het bewijs hiervoor is niet geleverd. Dezelfde auteur zag de kortere operatietijd bij de gestoten techniek als een woordeel. Waarschijnlijk is die stelling wel juist, maar daar stat legenover, dat het positioneren van de patient op de rektafel, het instelm len van de beeldversterker en de repositie van de lractuur nogal wat lijd vergen. Deze tijd is narcosetijd en verloopt tijdens een fase dat er nog geen operatiewond is.

\subsection{Operatietechniek}

Het tijdstip van operatie is van een aantal factoren afhankelijk. Bij multitraumapatiënten dienen, wanneer de patiënt qua circulatie en respiratie in een stabiele toestand verkeert, zo snel mogelijk alle fracturen van lange pijpbeenderen operatief gestabiliseend te worden ter preventie van "multiple organ failure" (Goris 1982) en om de patient verpleegbar te maken. Met welke vorm van osteosynthese men de fracturen stabiliseert, is op de eerste plats afhankelijk van de mate van het weke deten letsel en van het feit of de fractur open of gesloten is an op de tweede plaats. wan do mogelijkheden van het behandelend team. Bij 2 e en $3 \mathrm{e}$ graads gecompliceorde fracturen is hel, gezien de technische mogelikheden van de moderne fixateur externe systemen, een kunstfout on primair een intrdmedulkuire osteosynthese toe te passen. Een Grendelpenosteosynthese is een moeilije en technisch gecompliceerde ingreep; men dient te alten tijde te beschikken over een O.K.-team (chirurgen, instrumenterenden en personeel dat de beeldversterker bedient) dat avaren is in de loepassing van intramedulaire osteosynthesetechnieken indien men de fracturen van de onderste extremiteiten bij voorkeur a chaud the een Grendelpenosteosymhese wil behandelen. Indien men niet continu over een dergelijk O.K.-team kan beschikken, is het beter om de schachtfracturen van de onderste extremiteiten bij multitraumapatiënten met behuip van andere osteosynthesetechnieken (plaat, fixateur externe) te stabiliseren. Wel dient men, wanneer beide benen gefractureerd zijn, in verband met de revalidatie ernate te steven mimstens aan éen been een belastbare ostcosyn these te platsen.

Femurschachtricturen zonder begeleidende letsels kan men à chaud of na 10 dagen electief opereren. Bij het bepalen van het operatielijdstip speelt enerzijds het feit of men continu de beschiking heeft over een ervaren O.K. - team een belangrijke rol. Anderzijds hoeveel wadrde men hecht an de theorie dat uitgesteld opere- 
ren tot minder complicaties leidt omdat na 10 dagen reeds een uitgebreide revascularisatie van het bot aan de gang is (Charnley 1961 . Smith 1964, Wilber 1978).

Tweede- en derde graads open femurfacturen dienen niet primair met een intramedullaire osteosynthese gestabiliseerd te worden. In dergelijke gevallen is het beter om primair een uitvoerig debridement te verrichten met open laten van alle wonden (eventueel een fixateur externe osteosynthese bij multitraumapatiënten). Bij genezen weke delen kan dan alsnog een Grendelpenosteosynthese verricht worden. Zowel tijdens de Tweede Wereldoorlog (Raisch 1943) als tijdens de oorlog in Korea (Brav 1957) werden met deze behandeling in twee fasen goede resultaten behaald.

\section{Vóór de operatie}

Vóór men een Grendelpenosteosynthese verricht, dient men te controleren of het benodigde instrumentarium compleet is. Het is vanzelfsprekend dat de extensietafel en de röntgenapparatuur goed moeten functioneren. Indien men de patiënt electief opereert, dient men zich vór de operatie ervan te vergewissen, dat deze in goede conditie verkeert. Een infectie of een niet genezen wond in het operatiegebied of elders op het lichaam vormen contraïndicaties voor de operatie.

Het bovenbeen dient zó afgedekt te worden, dat, indien nodig, het hele femur operatief benaderd kan worden. Dit afdekken dient zeer zorgvuldig te geschieden, omdat het manipuleren met de beeldversterker en de richtapparatuur de steriliteit gemakkelijk in gevaar brengt .

\section{DE OPERATIE}

\section{Positie op de rektafel}

De operatie begint niet met het incideren van de huid, maar met het in een goede positie op de operatietafell leggen van de patiënt. Omdat voor het vergrendelen van de pen de beeldversterker absoluut noodzakelijk is, dient men de patiënt op een zogenaamde extensietafel te leggen, daar men anders niet kan manipuleren met de Cboog. Rugligging is de beste ligging, omdat men zo de rotatiestand van het been goed kan beoordelen en de kans op grote rotatieafwijkingen gering is. Het bovenlichaam van de patiënt dient zoveel mogelijk naar de gezonde zijde afgebogen te liggen. zodat er craniaal van de trochanter major in het verlengde van de femurschacht voldoende ruimte is om te werken met de diverse instrumenten die nodig zijn om een Grendelpen in te brengen. Vooral bijadipeuze patiënten is dit van belang.

Het gefractureerde been kan men op twee manieren extenderen. Men kan cen Steinmannpen door het condylenblok boren en wia een extensiebeugel het been opspannen. Hierbij is de knie $90^{\circ}$ gebogen (afbeelding 29). Deze techniek heef het nadeel, dat bij de distale vergrendeling de Steinmannpen met de extensiebeugel in de weg zitten en men niet met het richtapparaat kan manipuleren. Bovendien is het bij zeer distale femurfracturen, indien de knie $90^{\circ}$ gebogen is, in voor-achterwaart- 


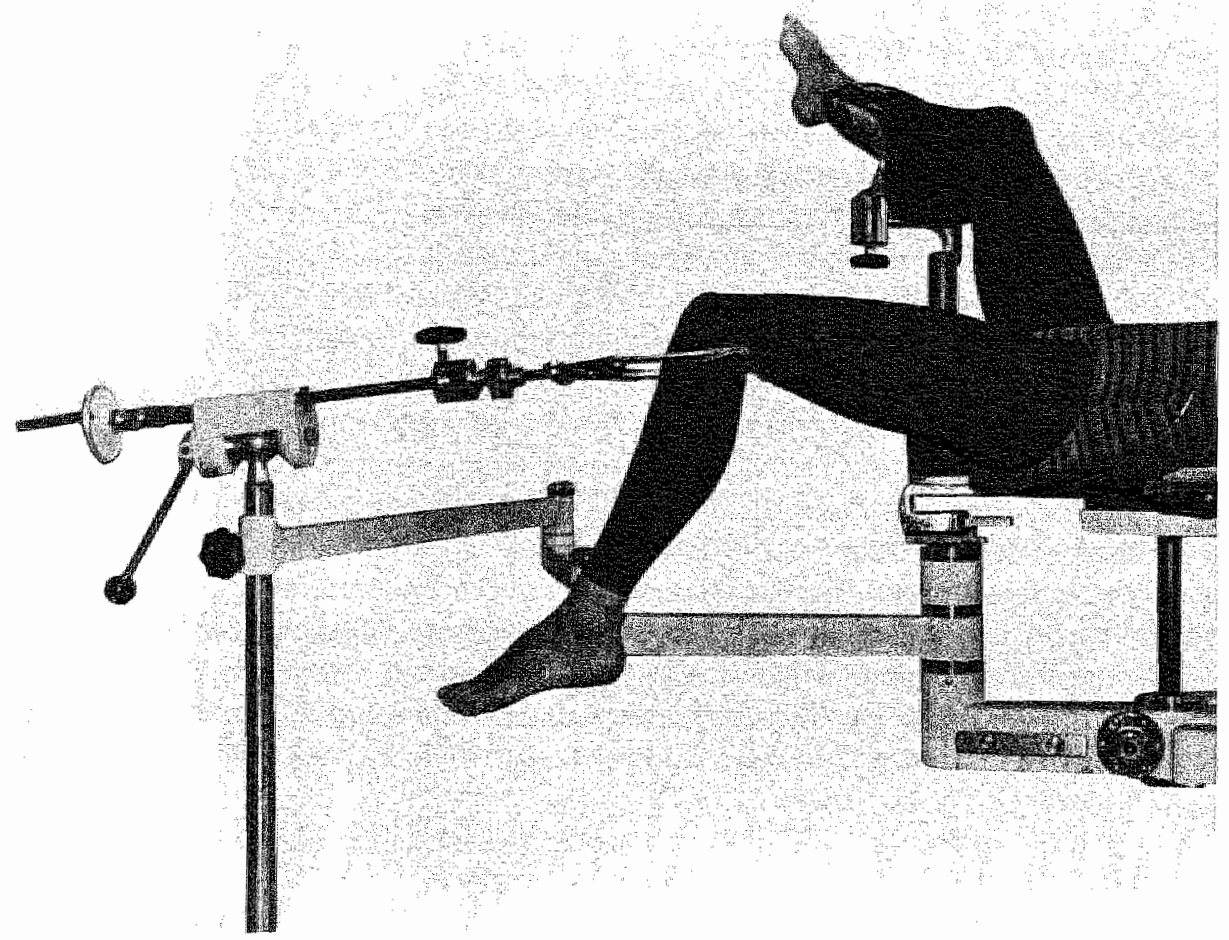

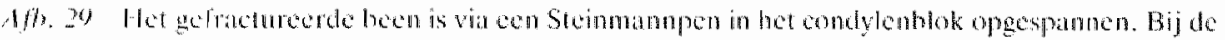

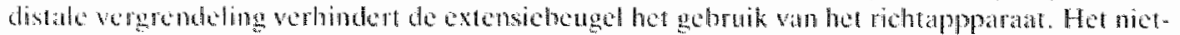

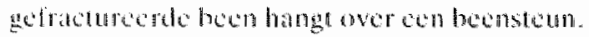

se richting niet mogelijk met de C-boog te werken. Het is dan ook beter om het been gestrekt op te spannen. Men kan dan bij clistale femurfiacturen zonder problemen van de richtapparatuur op de C-boog gebruik maken (afbeelding 30 ).

De ligging van het niet-gelractureerde been kan op een drietal manieren platsvinden. Allereerst kan men het been gestrekt opspannen, zodat men peroperatief de stand van beide benen kan vergelijken (afbeelding 31 ). Een andere mogelijkheid is het been te laten athangen over een beensteun (afbeedling 29). Bij (jonge) patiënton tenslotte met een goed beweeglijk heup-en kniegewricht kan het been met heup en knie maximalal gebogen in een speciale kous opgehangen worden, zodat men bij het gebruik van de beeldversterker total geen hinder van dit been heelt (atbeelding 32 en 33).

\section{De repositie van de fractur}

Wanneer de patiënt goed op de extensietafel lig», wordt getracht onder doorlichting de fractuur te reponeren. De extensiecafel wordt vastgezet in die stand, waarin de repositie zo optimaal mogelijk is. Wanneer de fractuur 1 à 2 weken oud is, lukt het soms wel de fractuur manueel goed te reponeren, maar kan deze repositie door de recls gevormde fibreuze callus met behulp van de rektafel niet gehandhatd wor- 


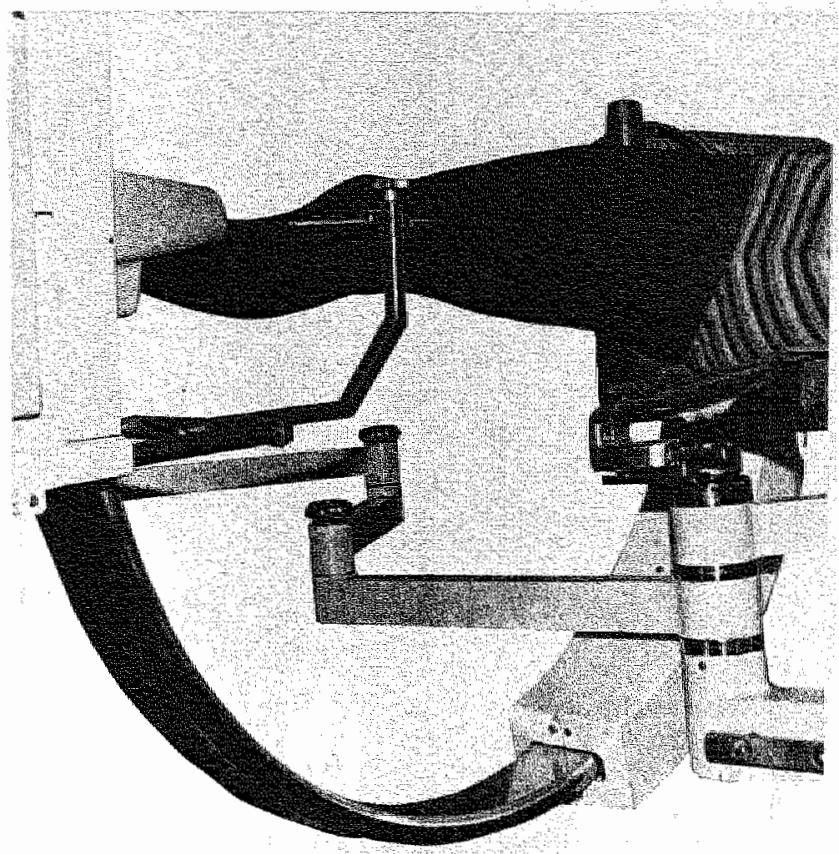

Afb. 30 Wanneer bet gefractureerde been gestrekt word opgespannen, kan men veel beter mei hed op de beoldversterker gemontecerde richtapparatu manipuleren.

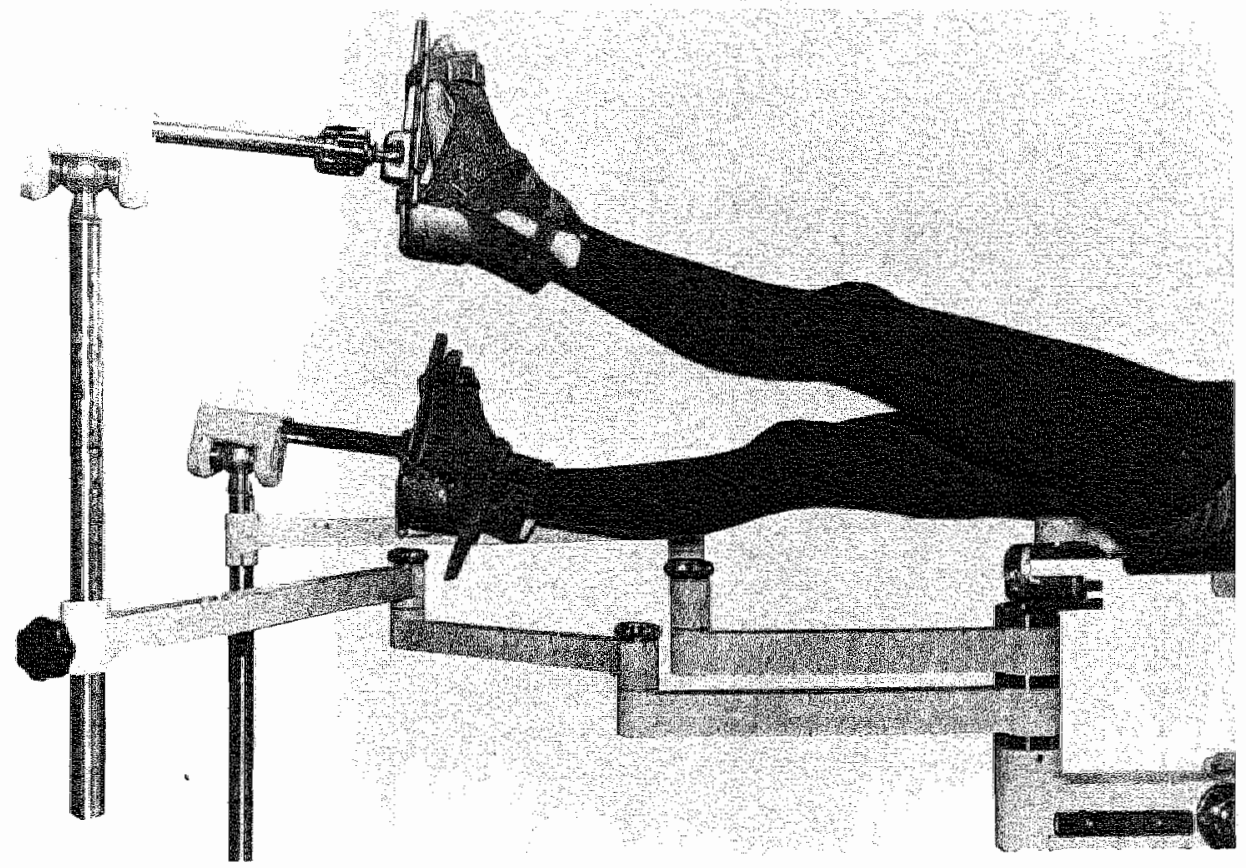

Afk. 9 Wannecr men de benengest rekt opspant kan men peroperatief de rotatic vergelijken. 


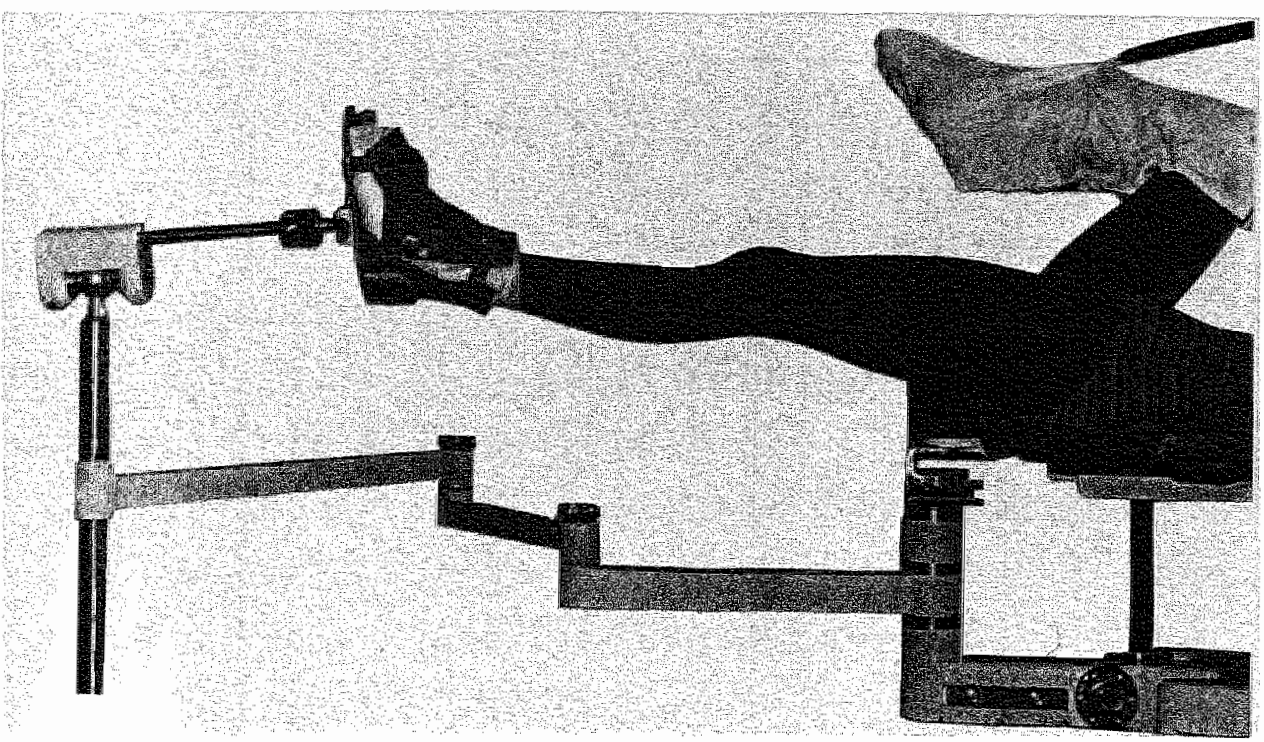

Aft. 32 an 33 Bij patienten met een good beweeglijk heup-en knicgewricht kan men het nict gefretureerde beow in een specialc kous ophangen, zodat men er met de beeldversterker geen hinder wan hestl

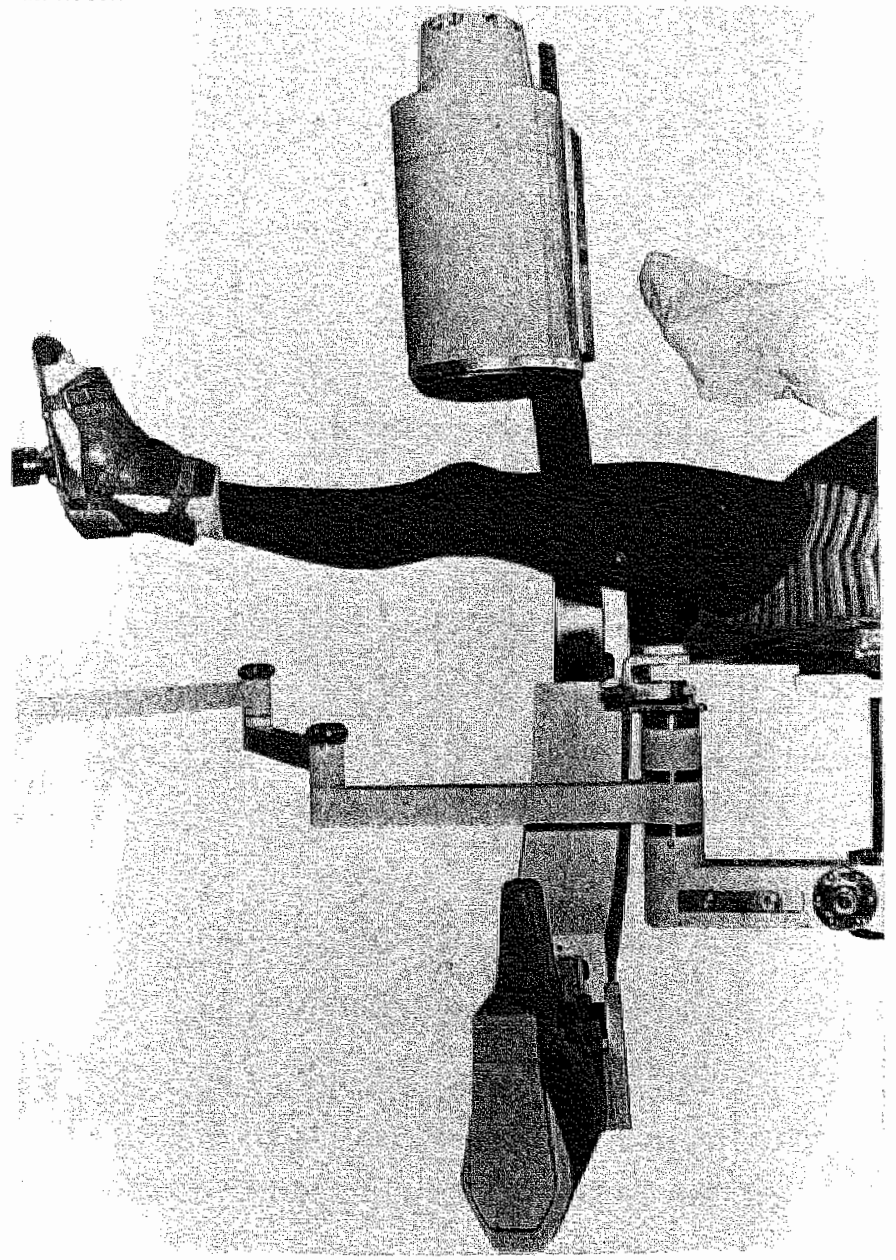


den. In dat geval wordt met de assistent de repositiemanoeuvre enkele malen geoefend, opdat deze dan tijdens de operatie probleemloos verloopt. Wanneer men bij proximale fracturen zonder de fractuur te openen een goede repositie wil bereiken. is het vaak nodig om thet been te abduceren. Dit makt het introduceren van de diverse instrumenten moeilijk. Indien de voerdraad de fractuur is gepasseerd, kan men het been adduceren zonder gevaar voor redislocatie en krijgt men meer ruimte voor het inslaan van de pen en het verrichten van de proximale vergrendeling. Bij distale fracturen kan een sterke adductie gunstig zijn voor het bereiken van een optimale repositie. In deze stand is het manipuleren met de instrumenten geen probleem.

Wanneer men de Grendelpenosteosynthese niet à chaud wil verrichten, maar pas na een aantal dagen, is het zeer belangrijk dat men een lichte distractie in de fractuur bewerkstelligt door voldoende gewicht atn de extensiebeugel te bevestigen. Het is dam beter om de snatartractie niet door het condylenblok maar door de tuberositas tibiac aan te leggen, omdat een Kirschnerdraad door het condylenblok een infectiebron kan betekenen wanneer men ter plaatse van de distale femurschacht moet opereren (distale vergrendeling).

Door een lichte distractie lukt het tijdens de operatie veel beter om te manipuleren met de hoofdfragmenten en wordt men niet gedwongen via de extensiemogelijkheid van de operatietafel, dus met geweld, de fractiur op lengte te brengen met het risico dat door teveel tractie letsels van de $\mathrm{N}$. ischiadicus worden veroorzakk. Bovendien wordt bij een sterke extensie de weke delen enveloppe rond het femur zó strak, dat er nauwelijks nog een mogelijkheid bestaat de fractuuruiteinden ten opzichte van elkaar te verplaatsen wat soms nodig kan zijn om de voerdraad op te kunnen schuiven. Operatietechnisch is de ingreep direct na het ongeval eenvoudiger dan na een aantal dagen, omdat door het ontbreken van een libreuze callus de repositie veel eenvoudiger is.

De operateur dient emaar te streven de Grendelpen via de gesloten operatietechniek in te brengen. Alleen bij irreponibele tracturen is het toegestaan viat een kleine laterale incisie de fragmenten te reponeren. Om een gesloten repositie te bewerkstelligen, kan men soms gebruik maken van de volgende kunstgreep: men boort het proximale hoofdfragment op en brengt een dunne Küntscherpen in de mergholte. Met het uitstekende deel van de Küntscherpen alls handvait kan het proximate hoofdfragment in de juiste positie gemanoeuvreerd worden. Vervolgens kan de voerdraad dóor de durne Küntscherpen in het distale fragment gebracht worden. 
ter major maar craniaal hie rvan in het verrden (afbeelding 34). Bij het bepalen van kening mee te houden, dat er vaak van init de incisie niet te krap mag zijn.

Afl. 34 De huidincisie dient nict over de trochanter major, mar cranial hiervan in het verlengde van de femursehacht gelegd to worden.

kige fascie worden de spiervezels van de $\mathrm{M}$. edius in het vezelverloop gespleten. Met de a trochanter major af om de juiste plats om lierma wordt de mergholte met de priem ge- niet te ver mediaal aan te priemen, omdat flexat femoris of het heupkapsel te laederen. urkopnecrose of een artritis kan resulteren. lateraal loopt men het risico dat de trochanen. In zijdelingse richting gezien, moet men set de punt licht naar vent raal gericht in veran de femurschacht (afbeelding 35 ).

rsterker de positie van de punt van de priem de mergholte is zeer belangrijk om bij het inie worden met een collumfractur bij een te an de laterale proximale cortex bijeen te la- 


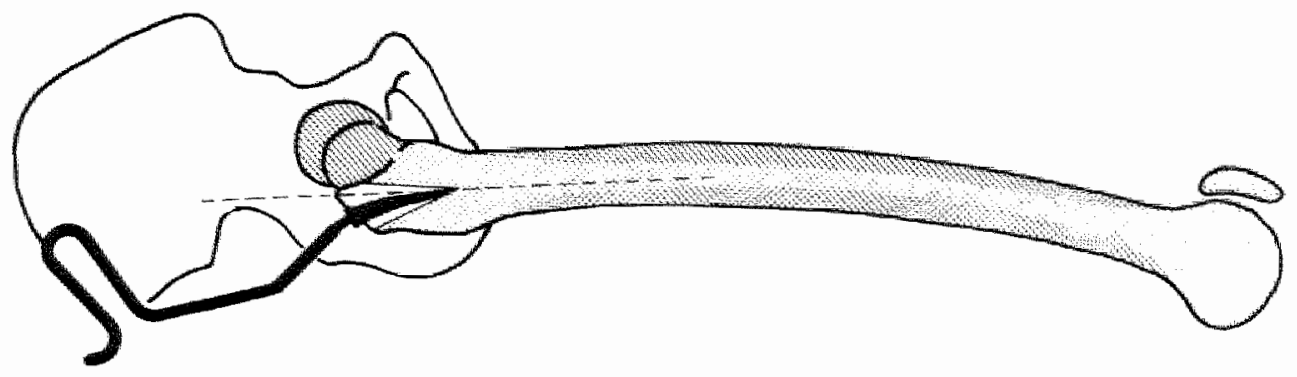

Afb. 35 Bij het inbremen van de prem dent de natumelijke anceurvatie vart de schach gevolged te worden.

\section{Introductie van de voerdraad}

Naclat met behulp van de priem een voldoende grote trechtervormige opening is gemakt, wordt de voerdraad met knopvormig verdikte punt ingebracht. Om het inbrengen en het passeren van de fractuur te vergemakkelijken, kan de punt licht gebogen worden. Als de voerdraad zich in de mergholte bevindt, wordt hij opgesehoven tot aan de fractuur, watana hij onder doorlichting in het distale hoofdragment word gebracht. Dit dient met de beeldversterker in twee richtingen gecontroleerd te worden om vast te stelten of de voerdraad zich distaal in de mergholte bevindt.

De voerdraad wordt zo ver mogelijk natar distaal opgevoerd en dient centratal in de mergholte te liggen om te voorkomen dat er bij het opboren van de mergholte toveel bot aan éên kant wordt weggefreesd.

\section{Opboren van de mergholte}

Indien de repositic geslaagd is, wordt gestart met het opboren van de mergholte mel de $9 \mathrm{~mm}$ boor, warna steeds een $0.5 \mathrm{~mm}$ dikkere boor wordt ingebracht. Het opboren dient gemakkelijk te gaan. Wanneer de boor stokt, boort men of te ver op of de boorkop is verstopt met boormeel. In het latsile geval dient men de boorkop te reinigen en opnieuw in te brengen. Lang doorboren bij cen grote weerstand is gevaarlijk daar het hierbij door de grote hitte kan komen $t o 1$ necrose van de cortcx (Povacs 1979). De mergholte dient $1 \mathrm{~mm}$ verder opgeboord te worden dan de diameter van de gekozen pen. Het passeren van een meerfragmentifactuur dicn met een niet roterende boorkop te geschieden, datar anders de marginale vascularisatio van de zich hierin bevindende fragmenten nog verder wordt beschadigd. Soms bevindt er zich een botfragment in de mergholte. Wanneer het niet mogelijk is dit fragment met enig manipuleren opzij te duwen, kan men de fractuuropenen via cen kleine incisie om zo het fragment te disloceren, in plats van te trachten door cindeloos verder te boren, het fragment als het ware te verpulveren. Bij 2-etagefracturen kan het middelste fragment in de regel normal opgeboord worden. De ervaring leert dat dit segment zeer stevig met de omgevende weke delen is verbonden, zodat er geen gevaar voor meedradien bestat. Uiteraard dient men in zulke gevallen niet tot het uiterste op te boren. 


\section{Keuze van de pen}

Nadat de mergholte is opgeboord, kan men de exacte lengte van de pen bepalen door het uitstekende deel van de voerdraad te meten en af te trekken van de totale lengte van de voerdraad. Bij fracturen met zeer ernstige verbrijzeling over een lang traject kan het moeilijk zijn peroperatief de juiste lengte, die het gefractureerde femur dient te krijgen, in te schatten. In zo'n geval is het beter om preoperatief een röntgenfotomet centimeterverdeling van het heterolaterale femur te maken, opdat men de lengte van de pen tevoren kan berekenen.
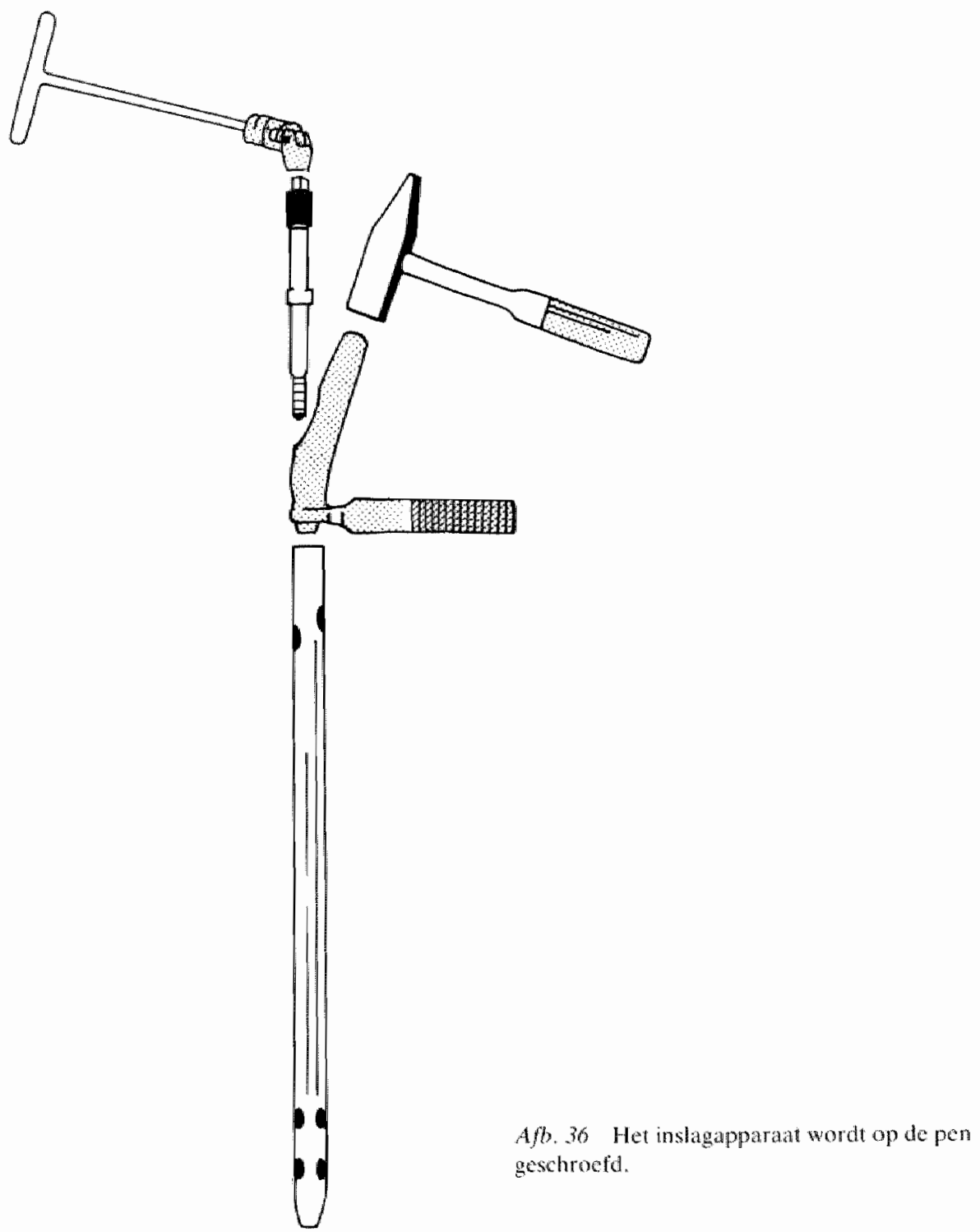
Nadat de Grendelpen met de juste lengte en diameter is uitgekozen (rechtsen links niet verwisselen), wordt het inslagapparaat proximaal op de pen gemonteerd (afbeelding 36). Vóor het inslaan van de pen wordt de voerdraad van de boor vervangen door een $4 \mathrm{~mm}$ dikke voerdraad zonder knopvormig verdikt uiteinde. Deze dikkere voerdraad geleidt de pen tijdens het inslatan en zorgt ervoor, dat de punt van de pen niet vastloopt in de cortex. Het inslaan van de pen moet met geringe weerstand mogelijk zijn. Ontmoet men teveel weerstand, dan dient men verder op te boren of een iets dunnere pen te nemen. Het is immers bij de Grendelpen niet persé noodzakelijk en bij meerfragmentfracturen ook niet mogelijk, dar de pen zowel proximaal als distaal in de mergholte klemt. Met behulp van de proximale en distale schroeven heeft men de mogelijkheid voldoende torsie- en lengtestabiliteit te verkrijgen. Wanneer bij het inslaan van de pen de schacht toch mocht splijten, geeft dit geen grote problemen. Men hoeft dan niet, zoals bij een normale pen zonder vergrendelingsmogelijkheid, over te gaan tot allerlei additionele osteosynthesetechnieken, die vaak tot ernstige complicaties leiden ten gevolge van de uitgebreide devascularisatie van het bot, maar men kan de pen eenvoudig statisch vergrendelen om toch een oefenstabiliteit te bereiken. Dit is ook een van de redenen waarom het voordelen heeft altijd een Grendelpen te nemen in plats van een gewone Küntscherpen. Bij het inslaan van de pen treedt er vaak enige distractie van de fractuur op. Wanneer men deze wil opheffen, dient men eerst distaal te vergrendelen. Met behulp van het uitslagapparaat kan men de pen nu iets terugslaan en zo de distractie opheffen. Bij meerfragmentfracturen zal dit uiteraard zelden of nooit nodig zijn. Het distale deel van de Grendelpen vertoont bij het inslaan ten opzichte van het proximale deel soms de neiging $20-30^{\circ}$ te endoroteren. Bij gewone pennen gebeurt dit ook, maar speelt dit geen rol, omdat er geen vergrendeling hoeft plats te vinden. Men kan deze endorotatieneiging enigszins anticiperen door tijdens het inslaan de pen $10-20^{\circ}$ te exoroteren.

\section{Vergrendeling}

Na het inslaan van de pen $k$ an de vergrendeling plaatsvinden. Op het moment dat de pen nog $\pm 10 \mathrm{~cm}$ boven de trochanter major uitsteekt, dient men het inslagapparat te verwisselen voor bet proximale richtappataat (Howmedical") (albeelding 371). Wanneer de pen te ver is ge introduceerd, is het moeilijk het richapparat op de pen te monteren, omdat vooral bijadipeuze patiënten de weke delen het richtapparatat volledig omhullen. Via dit richtapparaat kan men nu de schroef voor de proximale vergrendeling inbrengen vanuit de trochanter major via de penopeningen natar de trochanter minor. Deze schroef makt een hoek van $130^{\circ}$ met de pen. In de penopeningen is dralad getapt, zodat deze schroef stevig met de pen verbonden is en er geen gevaar voor losraken bestat.

Bij het maken wan het proximale boorkanaal ( $5 \mathrm{~mm}$ boor) (afbeelding 37-3) dicnt geen kracht op de boor uitgeoefend le worden, data deze vanwege zijn lengte enigszins llexibel is waardoor de punt uit de asrichting van het boorkanaal kan raken en zelfs kan breken wanneer hij in contact komt mel de rand van de penopening. Bij een niet geheel zuivere asrichting kan de starre schroef (diameter $6.35 \mathrm{~mm}$ ) do le- 
genoverliggende penopening niet bereiken. Voordat men start met boren, dient men de laterale cortex dan te priemen, zodat de boor niet uitglijdt langs de laterate cortex (afbeelding 37-2). Men moet alleen de laterale cortex perforeren met de priem. Wanneer men de priem te ver inbrengt, beschadigt men de schroefdraad die in de penopeningen is getapt, waardoor het indraaien van de schroef (afbeelding $37-4)$ bemoeilijkt wordt en soms zelfs onmogelijk is.

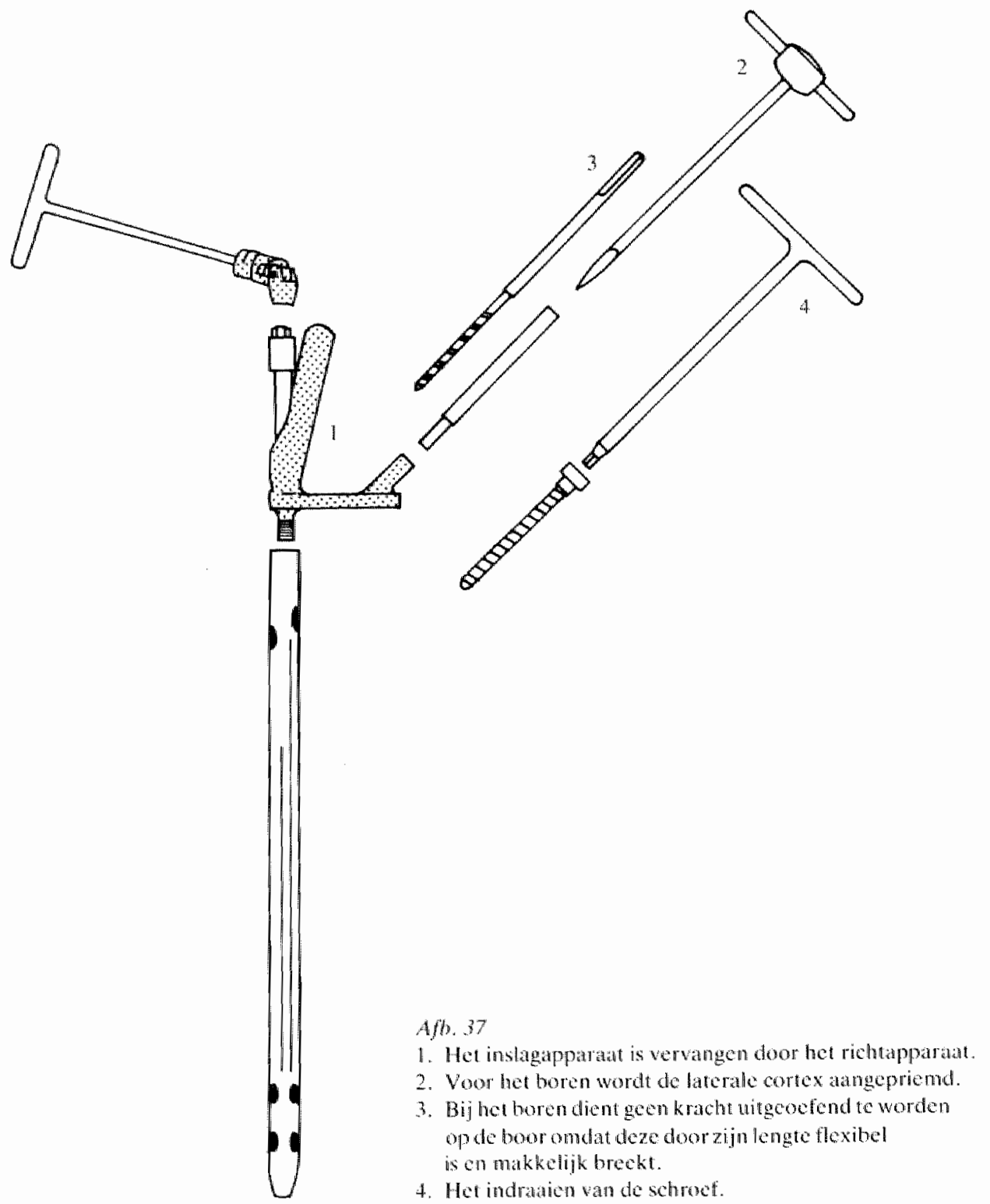


Voor de distale vergrendeling worden allereerst de distale penopeningen loodrecht ingesteld met de beeldversterker. Deze openingen moeten precies loodrecht getroffen worden met de beeldversterker om in de goede asrichting te kunnen boren (afbeelding 38-1). Vervolgens wordt een steekincisie gemaakt aan de laterale zijde van het distale bovenbeen op de plaats waar éen van beide penopeningen zich projecteent. Met de priem wordt nu in de voorste cortex een opening gemaakt ter plaatse van de penopening (afbeelding $38-2$ ). Met de $4,5 \mathrm{~mm}$ boor worden nu beide cortices doorboord (afbeelding 38-3) en aansluitend wordt de voorste cortex opgeboord tot $6 \mathrm{~mm}$ (afbeelding 38-4). Na het meten van de gewenste lengte van de schroef wordt deze ingebracht met de imbusschrocvendraaier (afbeelding 38-5). Op dezelf-

\section{0}

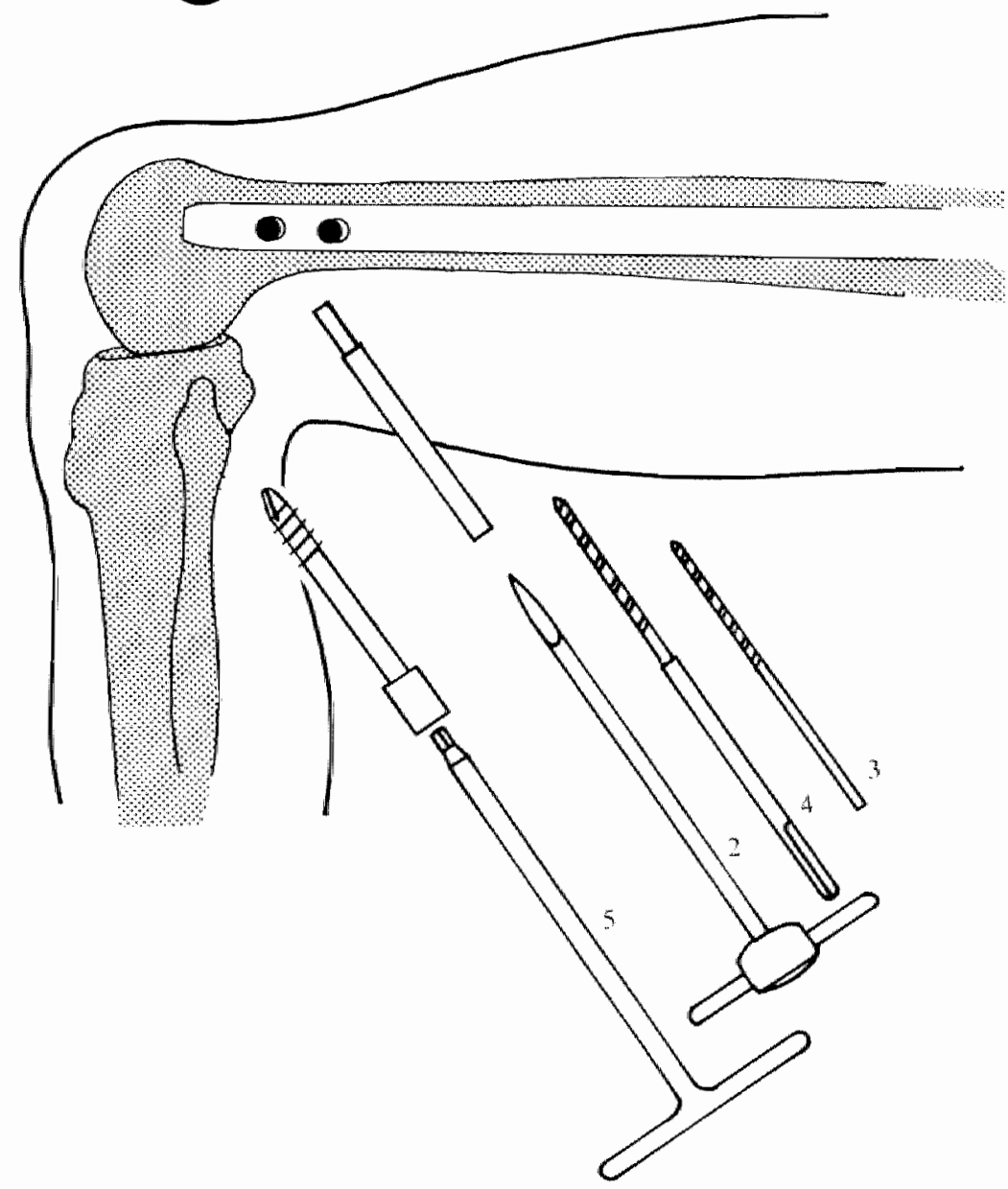

Afb. 38

1. De openingen in de pen noeten met de bockdversterker loodrecht getroffon worder.

2. Het azupriemen van de voorste contex.

3. Doomboren van beide contices met de 4.5 mm boor.

4. Opboren van do voorste cortex tot $6 \mathrm{~mm}$.

5. Inbrengen van de schroet. 
de wijze kan de tweede schroef worden ingebracht. Het is noodzakelijk beide schroeven in te brengen, omdat anders de pen kantelbewegingen kan maken met de schroef als as. Bij de Howmedica'-pennen bevinden deze openingen zich op respectievelijk $2 \mathrm{en} 4.5 \mathrm{~cm}$ van de distale punt. In bijzondere gevallen is het mogelijk de punt nog $1 \mathrm{~cm}$ in te korten, wanneer dit nodig mocht zijn om beide penopeningen distaal van de fractuur te brengen. Om de schroeven een stevig houvast te garanderen, is het noodzakelijk dat zij 3 a $5 \mathrm{~mm}$ uit de tegenoverliggende cortex steken. De schroeven voor de distale vergrendeling hebben een eindstandige zelftappende schroefdrad. Deze schroeven dienen met de schroevendraaier te worden ingedraaid ook wanneer dit moeizaam gaat. Men moet zich niet laten verleiden de schroeven mel ecn hamer in te slaan, omdat fissuren in de tegenoverliggende cortex kunnen ontstaan, waardoor de schroef snel losraakt wanneer de patiènt gemobiliseerd wordt en het systeem voortdurend microbewegingen moet opvangen.

Voor de distale vergrendeling kan men ook gebruik maken van het richtapparaat volgens Lafforgue en Crosse (1978). Dit richtapparat heeft het voordeel dat het op de C-boog van de beeldversterker kan worden gemonteerd (afbeelding 30). Door met de C-boog te manipuleren, kan men de geleidehuls van het richtapparaat en de penopening over elkaar projecteren, waarna men via de geleidehuls kan boren en de schroef kan inbrengen. Een nadeel van dit richtapparaat is, dat de montage op de C-boog niet erg stabiel is, zodat tijdens het inbrengen van de priem of de boor het gevaar bestaat, dat men net een paar millimeter nast de penopening geraakt. Richtapparaten op electromagnetische grondslag, waarmee het mogelijk wordt de distale schroeven zonder röntgendoorlichting in te brengen, worden momenteel klinisch getest en zullen binnenkort in de handel verkrijgbaar zijn.

\section{Verwijderen van een Grendelpen}

Bij de Howmedica ${ }^{\mathrm{T}}$-pennen zijn de proximale $5 \mathrm{~cm}$ van de pen gesloten. Dit heeft het voordeel dat de torsiestabiliteit van de pen wordt vergroot. Aan de bimnenzijde wan het gesloten deel bevindt zich een schroefdraad. Om cie pen te verwijderen, kan hierin een stat worden geschroefd, wataan het extractie-apparaat, bestaande uit een lange staal met een glijgewicht, kan worden bevestigd.

\section{Ortopedia"-systeem}

Natast de Howmedica'-Grendelpen is er nog een Grendelpen van de firma Ortopedia ${ }^{r}$ op de markt (afbeelding 39 ). Beide systemen hebben hetzelfde werkingsprincipe, malar de Howmedica'-pen heeft betere biomechanische eigenschappen en hel instrumentarium is technisch meer geperfectioneerd.

De Ortopediat -pen heef dorsall een spleet over de volledige lengte van de pen, watrdoor de rotatiestabiliteit minder is dan bij de Howmedicar ${ }^{r}$-pen. Om de torsiestabiliteit tijdens het instan te vergroten, word gebruik gemaakt van een inzetstuk, watrdoor het proximale deel van de pen wordt verstijfd tujdens het inslaan van de pen. Voor het inslaan van de laatste centimeters van de pen wordt dit lange inzetstuk vervangen door een kort, omdat anders de proximale schroef niet kan worden ingebracht. Inslag- en richtapparaat zijn bij het Ortopedia'-systeem één en dezelfde. De proximale schroef van het Ortopedia'-systeem maakt een hoek van $150^{\circ}$ met 


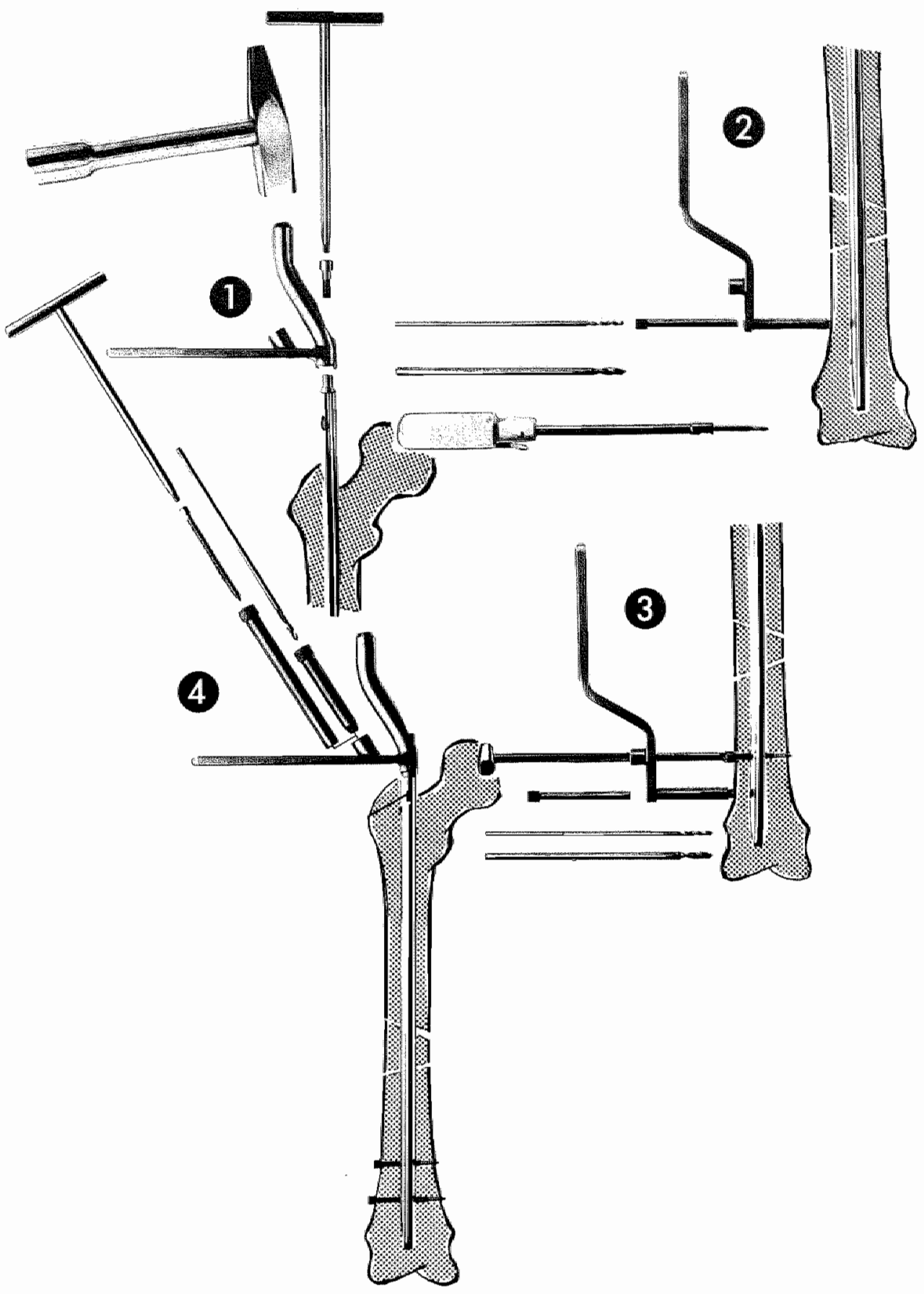

Afo. 39 Het Ortopedia'-syteom.

1. Hel imslan van de pen.

2 en 3. De distale vergrendeling.

4. De proximalo vergrendeling. 
de pen in tegenstelling tot de Howmedica ${ }^{5}$-pen, waarbij deze hoek $130^{\circ}$ bedraagt. Dill verschil is normaliter van geen belang, behalve wanneer men een heterolateralepen wil introduceren (variant van Vecsei). De hoek die de dijbeenhals met de femurschacht maakt, varieert gemiddeld van $120-133^{\circ}$. Wanneer men bij de Ortopedia"pen de variant van Vècseil wil toepassen, wordt men gedwongen om de top van de pen 1 à $2 \mathrm{~cm}$ te verzinken onder het niveau van de trochanter major omdat anders de proximale schroef, die een hoek van $150^{\circ}$ met de pen maakt, uit de dijbeenhals loopt. Daar de Ortopediar -pen een spleet over de volledige lengte van de pen bezit, is het proximale deel van de pen circulair samendrukbaar. Hierdoor kunnen er verschillen ontstaan in de afstand tussen de penopeningen waardoor de proximale schroef wordt ingebracht. Vanwege het feit dat in deze openingen schroefdraad getapt is, kan een variabele afstand tussen beide openingen problemen geven bij het inbrengen van de proximale schroef.

Met betrekking tot de distale vergrendeling is er weinig verschil. De voor de Howmedica ${ }^{r}$-pen beschreven methoden kunnen ook bij de Ortopediar-pen toegepast worden. Het Ortopedia'systeem bezit bovendien nog een eigen richtapparaat (afbeelding 39-2 en 3 ) voor de distale vergrendeling, hetgeen bestaat uit twee geleidehulzen, die $3 \mathrm{~cm}$ van elkara aan een lang handvat zijn bevestigd. Wanneer men de eerste schroef heeft ingebracht, kan men één geleidehuls laten afsteunen op de kop van deze schroef, zodat de tweede schroef wrijwel zonder röntgendoorlichting kan worden ingebracht.

Bij de Howmedica ${ }^{r}$-pen bevinden zich beide distale penopeningen op 2 en $4,5 \mathrm{~cm}$ van de punt. Deze afstanden zijn bij de Ortopediat ${ }^{r}$-pen respectievelijk $4 \mathrm{en} 7 \mathrm{~cm}$, hetgeen tot nadeel heeft dat bij zeer distale fracturen de punt van de pen soms ingekort moet worden, omdat anders de distale penopeningen zich niet distaal van de fractuur bevinden.

De Ortopedia'-pen heeft aan de voorzijde van het proximale pengedeelte een opening. Om de pen te verwijderen, dient men een uitslaghaak door deze opening te steken. Aan deze uitslaghaak kun het extractie-apparaat, bestaande uit een lange stauf met een glijgewicht, worden bevestigd. Wanneer de pen erg vast in de mergholte geklend zit, bestaat het gevaar. dat het "oog" van de pen uitscheurt.

Om dit probleem te vermijden, $k a n$ men beter gebruik maken van een door Schellmamn (1982) ontwikkeld uitslagapparaat dat op de pen geschroetd kan worden. Waaraan dan de slat met glijgewicht bevestigd wordt. Met dit instrument bereikt men een zeer stevige verbinding tussen pen en uitslagapparaat en vermijad men het tuitscheuren van de opening in de pen (afbeelding 40).

De distale punt van de Howmedicat -pen is mooi rond afgewerkt, zodat het gevaar dat de punt tijdens het inslaan vastloopt op de cortex vrijwel nihil is. Bij de Ortopediat ${ }^{r}$-pen is dit niet het geval en moet men zeer goed oppassen dat de punt niet als een holle beitel vastloopt.

\subsection{Revalidatie na osteosynthese}

De revaliditte van de traumapatiënt is een belangrijk onderdeel van de behandeling. Vooral bij multitraumapatiënten is een vroegtijdige samenwerking tussen chirurg en revaliderend team van groot belang. Al tijdens de intensive care fase zijn er 


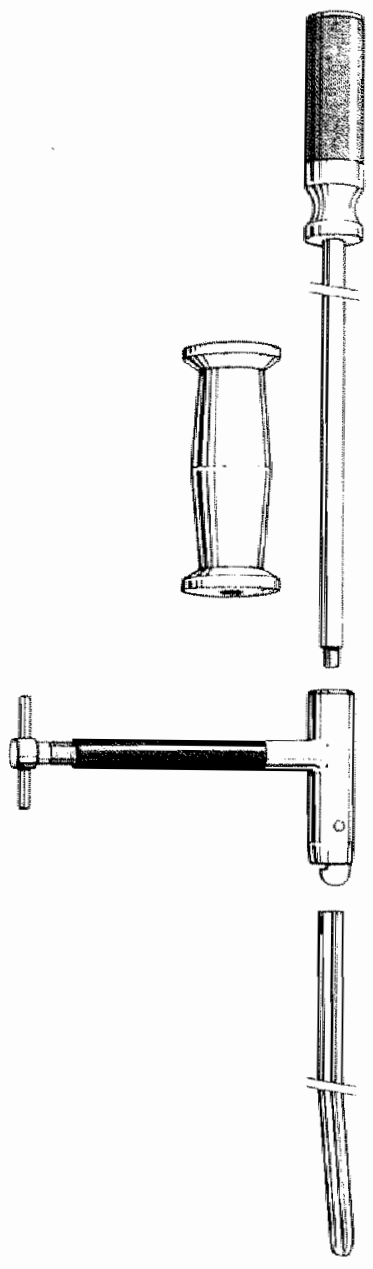

Afb. 40 Het door Schellmann on wikkelde. uistagapparat voor dic Oropediarpen.

voor fysiotherapeut en verpleging duidelijke taken.

Niet gekwetste gewrichten worden bij voorkeur in de zogenaamde 0-positic gebracht, waarin het gewrichtskapsel maximaal ontspannen is. Ter contractuupreventie moeten alle niet getroffen gewrichten regelmatig passief bewogen worden (Schlegel 1971). Tevens dienen er maatregelen genomen te worden ter preventie van thrombo-embolische en pulmonale complicaties en het optreden van decubitus. Bij een multitraumapatiënt dient naast andere ondersteunende therapie oraal en parenteraal hyperalimentatie toegepast te worden (Mühe 1977).

De laatste decennia is bij de fractuurbehandeling de fysiotherapeutische begeleiding intensiever geworden. Waar 40 jaar geleden nog vele femurfacturen mel langdurige immobilisatie werden behandeld (Bonnin 1946), is het tegenwoordig zo, dat de patient de dag na operatie voor de eerste maal zijn gefractureerde been weer kan bewegen. De voordelen van de osteosynthese liggen niet in het feit dat ereen snellere botgenezing optreedt, maar dat wanneer de fractuur geconsolideerd is er niet alleen een belastbare extremiteit aanwezig is, maar dat er weer een normale functic van de aangrenzende gewrichten bestaat zonder dystrophische afwijkingen 
(Tscherne 1971). Een osteosynthese is alleen zinvol. wanneer hierdoor oefenstabiliteit bereikt kan worden (Schauwecker 1972). Aan deze eis voldoet een osteosynthese met een Grendelpen rumschoots.

Patiënten zonder begeleidende letsels met een meerfragment- of etagefractuur van de femurschacht die gestabiliseerd is door middel van cen Grendelpen kunnen in principe de dag na operatie gemobiliseerd worden. Wanneer er begeleidende letsels zijn die een vroegtijdige mobilisatie verhinderen, wordt het been op een Braunse slede geplatst met heup-en kniegewricht in flexiestand. Dit heeft het voordeel dat wanneer de patiënt actief zijn kniegewricht gata bewegen, hij sneller een goede flexiemobiliteit bereikt, dan wanneer het been tevoren enige tijd in strekstand werd geimmobilisecrd (Mülter 1977).

De beweeglijkhcid in het kniegewricht verdient speciaal de aandacht, omdat de distale schroeven valuk de recessus suprapatellaris perforeren, hetgeen tot een prikeling van her kniegewricht kan leiden. Dit kan een verkleven van de recessus veroorzaken tnet een bewegingsbeperking van het kniegewricht. Wanneer patiënt in stat is zelf te oefenen, voldoet de zogenaamde "Frankfurter Bewegungsschiene" goed. Herin kan de patient zijn been passief maar ook progressief actief oefenen.

Patiënten met een dynamisch vergrendelde pen kunnen in principe volledig belasm ten. Bij een statische vergrendeling kan dit gezien de mechanische eigenschappen van het materiaal niet, omdat het osteosynthesemateriaal niet in staat is alle krachten, die op het femur uitgeofend worden, op te vangen. Bij een primair statische vergrendeling vormt een belasting direci postoperatief van 10 à $20 \mathrm{~kg}$ geen enkel probleem. Bij de eerste röntgenologische tekenen van callusvorming $8-12$ weken postoperatief kan dit na dynamsering wan de osteosynthese worden uitgebreid tot volledige belasting. Een dergelijke snelle revalidatie en vooral de mogelijkheid om zo kort na de operatie het been pijnloos te bewegen en er (gedeeltelijk) op te steunen. is natuurlijk ook uit psychologisch oogpunt van enorm belang voor de patiënt.

Vobr het invoeren van de Grendelpentechniek had men bij een lemurfractur met uitgebreide verbrijzeling de keuze uit de niet-operatieve behandelingstechnieken gipsimmobilisatic en tractie en de operatieve behandelingstechnieken plaat-, mergpen-(al dan niet met cerclagedraden) en fixateur externe-osteosynthese.

Vatk ook paste men een combinatie van operatieve en niet-operatieve technieken too. In dergelijke gevallen hebben zowel plat als pen slechts een reponerende lunctic en kan er niet wan een oefenstabiele osteosynthese gesproken worden. De nadelen van het openen van de fructuur, het devasculariseren van het bot en de gevaren van een langdurige immobilisatie, wegen niet op tegen het relatieve voordeel van een betere repositie. 


\subsection{Specifieke complicaties}

Bij een Grendelpenosteosynthese kunnen alle complicaties optreden die inherent zijn aan de intramedullaire osteosynthesetechniek in het algemeen. Deze complicaties zijn door diverse auteurs (Küntscher 1945, 1962. Lemmens 1981, Mataz 1983. Stapert 1983) uitvoerig beschreven, zodat met een kont overzicht volstatan kan worden (tabel 7$)$.

\section{Tubel 7 Complicaties bij de intramedullate osteosynthesetechniek in het algemeen}

1. Fissuren buiten het fractuurgebied niet opgemerkt.

2. Instrumentarium incompleet of defect.

3. Verkeerde ligging van de patiënt.

4. Fontief afdekken van het operaticgebied.

5. Onvoldoende tepositie vande fractunur.

6. Foutieve ligging van de boorgeleider.

7. Vastlopen of breuk van de boor.

8. Het veroorzaken van hittenecrose van het bot.

9. De aanwezigheid van botfragmenten intramedullăr.

10. Het opboten van een verbrijzeld fractuurgebied.

11. Het vastlopen van de pen tijdens het inslaan.

12. Splijten van de femurschacht tijdens het inslaan.

13. Het optreden van rotatiea twijkingen.

14. Pen buiten de mergholte (afbeelding 41).

15. Het breken van de pen.
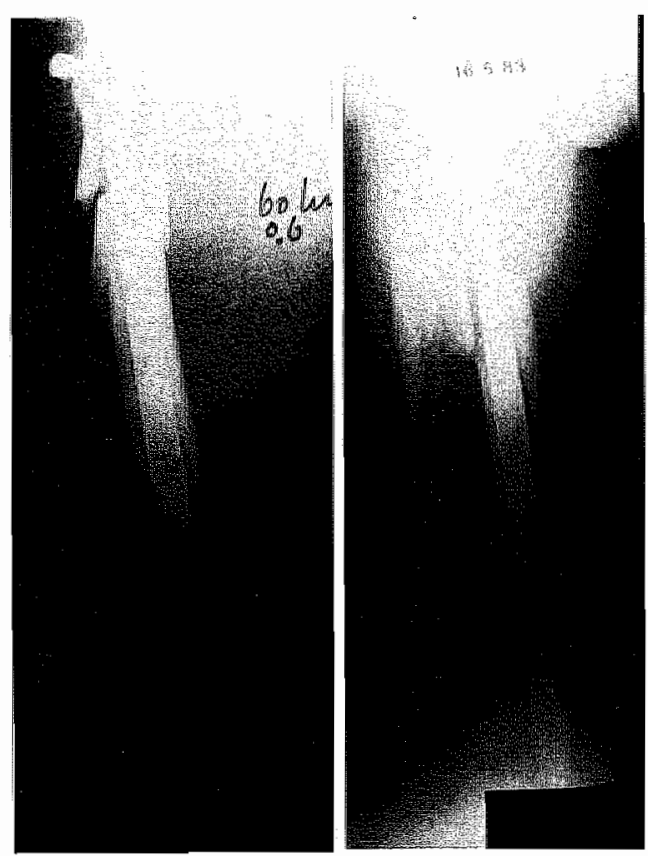

di

b

Afb. 4 Bij deze femurfactuu bleck pas posioperatief dat de pen buiten de mergholie van het proximale hoofdfragment was ingebracht.
a. A.P. röntgenfoto

b. Zijdelingse opname 
Er zijn een antal complicalies lijdens en na de operatie die specifiek zijn woor de Grendelpenosteosynthese (tabel 8).

Voorzover deze nog niet werden besproken in hoofdstuk 6.5. zullen deze complicalies worden toegelicht.

\section{Tothels Complicates specifick voor de Grendelpentechniek}

1. Verwiseling van rechter en linker pen.

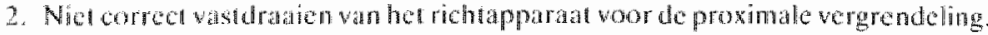

7. Beschadigen mot de priem van de sethoe forad in de proximate penopeningen.

4. Foureve ligging of vahtlopen van de proximale seluroef.

5. Breuk vandespiraboor.

6. A giglijen van de boorlangs de laterale cortex.

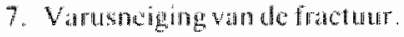

8. Fonticye ligging of nict kunen inbengen wan de dist ale schroeven.

\%. Her inbrengen van stechis ben distale sehroed.

16. Diantass in het fracturagebiod.

11. Dynamisclue in plats van statsiche vergrendeling.

12. Lubrenger ván de distale sehrover via sen mediale incisic

1.6. Het inhrengen van selnowen met cen fout teve lengte.

14. Secundat lostiken wandeschoeven.

15. Het breken wan de pen of de sehrowen.

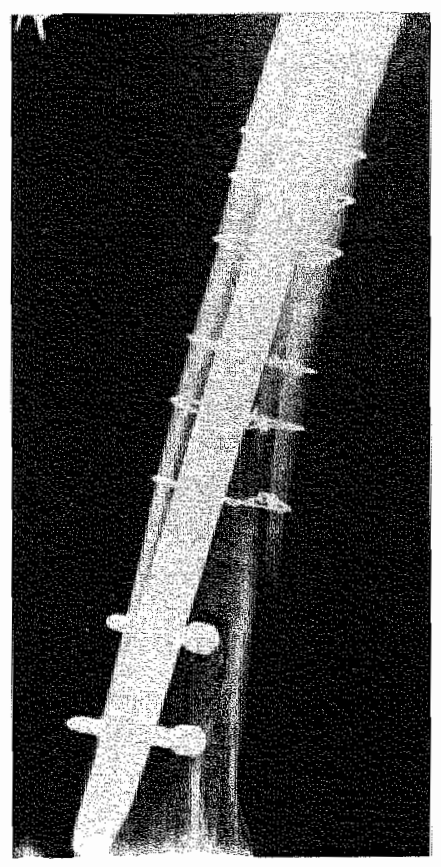

Ajy. 22 Bij deze hathur werden propperatiof de fissuren in de metaphyse niet opgemerkt. Tijdens operatic bleken de distale sonoeven geen enkele extratabilteit aan de osteosynthese te geven. zodat cen zestal cerelages werden aangebrach. 
Men dient bij iedere femurfractuur die men met een intramedullaire osteosynthese wil stabiliseren, röntgenfoto's van heup-en kniegewricht te maken en deze nauwkeurig te bestuderen op de aanwezigheid van eventuele fissuren. Bij een Grendelpen geldt dit in het bijzonder, ondat de schroeven geen functie hebben, wanneer men deze plaatst in een gebied met fissuren waardoor de osteosynthese geen lengteen rotatiestabiliteit heeft (afbeelding 42).

Er bestaan aparte Grendelpennen woor het rechter en het linker femur. Indien men deze verwisselt, is het niet mogelijk de proximale schroef met behulp van het standaard-richtapparaat in te brengen.

Met behulp van het proximale richtapparat is het in de regel zeer eenvoudig de proximale schroef in te brengen. Wanneer dit niet probleemloos gaat, bestaat de mogelijkheid, dat men de schroef vóór of achter de pen plaatst, waarbij iedere stabiliserende functie van de schroef verloren gat (afbeelding $43 \mathrm{at} / \mathrm{md}$ ).

Bij het Howmedical ${ }^{2}$-systeem dient het proximale richtapparat zeer stevig op de pen geschroefd te worden. omdat anders het richtapparat in geringe mate kan roteren met de pen als as watardoor de boor in plaats van dóór de proximale penopeningen vór of achter de pen kan geraken. Vóór men staur met boren, dient men te controleren of het proximale richtapparaat tijdens het inslatn van de pen niet is gaan loszitten. In het laatste geval dient de schroel, watrmee het richtapparaat op de pen is geschroefd, stevig aangedraaid te worden (afbeelding 37-1).

Men dient vóor het inbrengen van de Grendelpen altijd te controleren of de schroefdrad in de penopeningen intact is. Wanneer het ondanks alle voorzorgsmatregelen niet lukt de proximale schroef dóor de pen in te brengen, kan men een andere pen nemen of men kan in plaats van de originele proximale schroef een 4,5 $\mathrm{mm}$ corticalisschroef nemen. Dit laatste dient slechts in uiterste noodzaak te gebeuren daar deze schroef geen vaste verbinding met de pen heeft waardoor de stabiliteit veel minder en de kans op schroefbreuk vele malen groter is (afbeelding 44).

Het boren van het proximale schroeflkanaal dient zeer behoedzatam te gebeuren, ondat de boor door zijn lengte nogal flexibel is en bij contact met de rand van de penopening snel breekt. Wanneer de afgebroken boorpunt niet via de wond geextraheerd kan worden, is het radzaam met behulp van een drevel de boorpunt naar de mediale zijde van het bovenbeen te duwen en deze aan het einde van de operatic via een kleine steekincisie te verwijderen. Er bestat weinig gevaar de arteria of vena femoralis te laederen omdat deze meer ventrall lopen.

Wanneer in het proximale deel van de schacht de mediale cortex ontbreekt ol de mergholte extreem wijd is, heeft de fractuur een sterke varus tendens. Men kan dit voorkomen door de toegang tot de mergholte iets verder mediaal te kiezen dan gebruikelijk en door de stand van de hoofdfragmenten tijdens het opboren en inslann van de pen over te corrigeren in een lichte valgusstand.

De distale schroeven zijn moeilijker in te brengen. De beeldversterker is hierbij nodig om precies de penopeningen te kunnen localiseren. Het kan heel gemakkelijk 


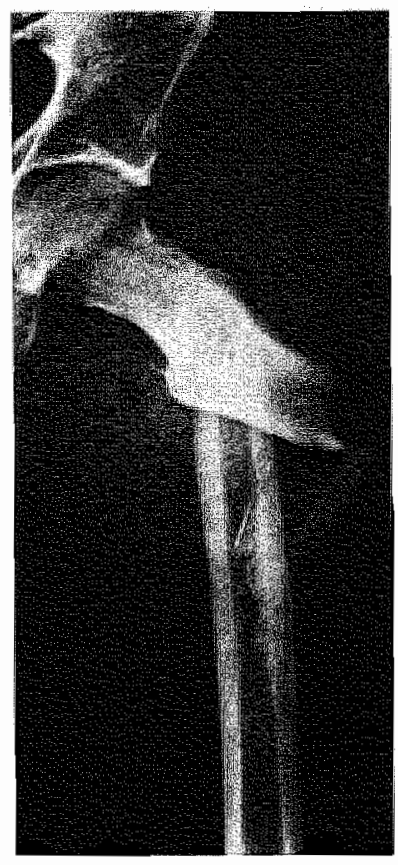

al

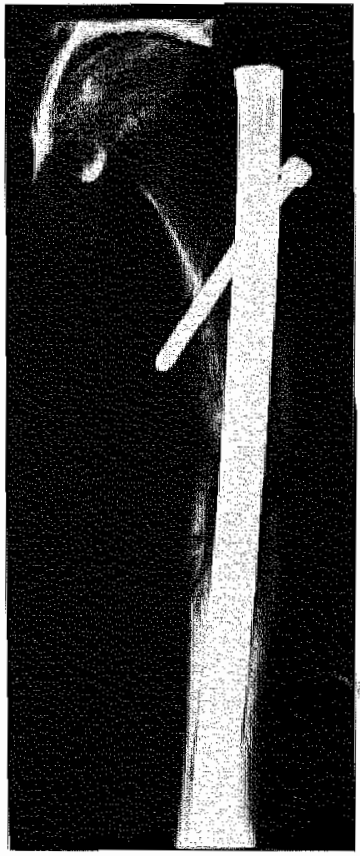

t:
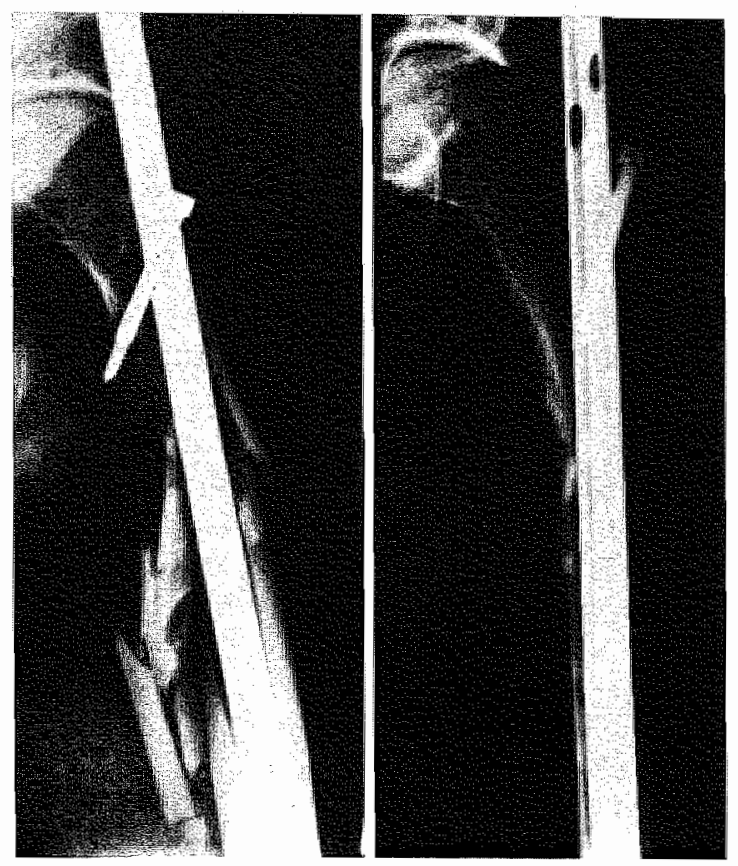

b
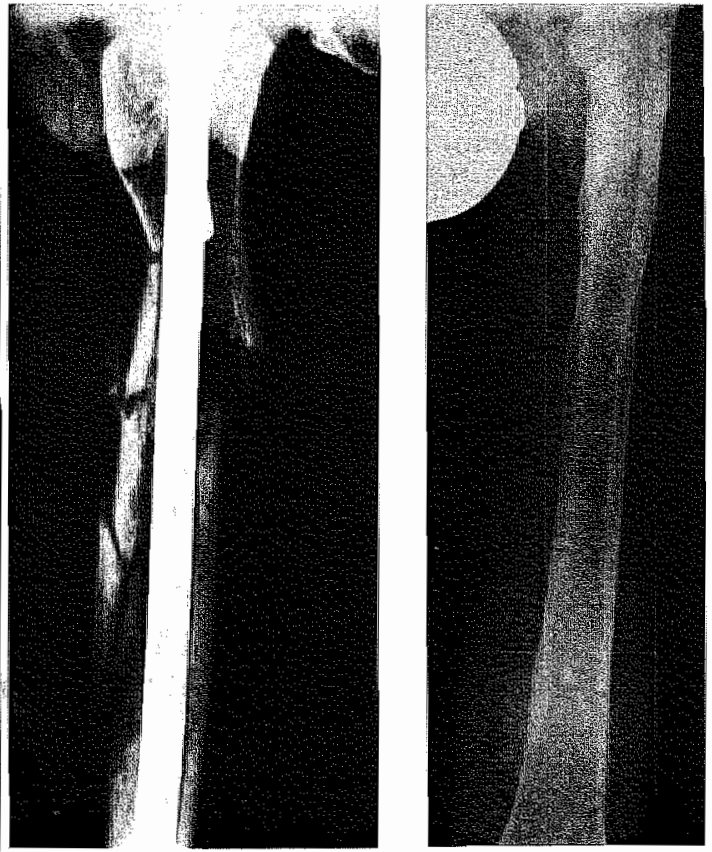

d

Ab. 43 Patient FolO, 27 jaar. a. Röntgenfoto dag van opname. b. Vijf dagen na operatie. De proximate sehroef is ichler de pen geptatst en de fractuar is gecollabecrd. $c$ Veertien dagen na re-osteosynthese. wien jaar ma het ongeval. 


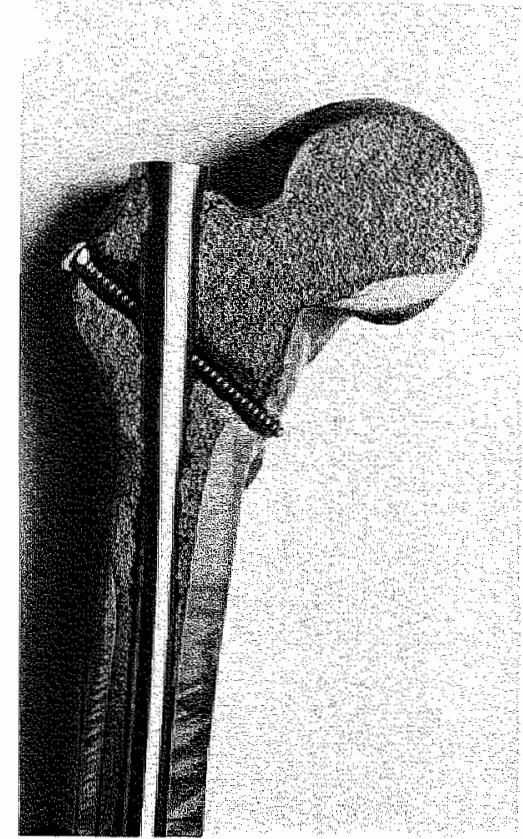

Afo. 44 In witerste noodzatak kan in plakts yan de originele schroel voor de proximale vergrendeling en $4.5 \mathrm{~mm}$ conticalisschroef genomen worden.

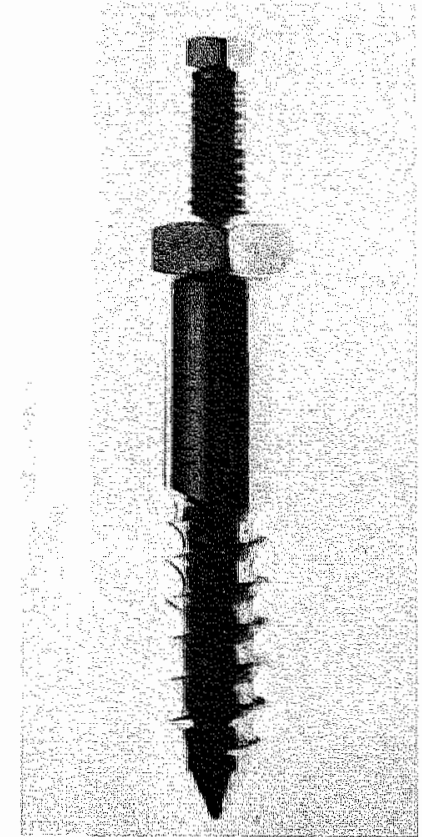

Afo. 45 Wamner de distale sellower onvoldoende houvast heeft, kan men ece doon Vecsei ontwik kelde keillow ("towmedicas") nemen.

gebeuren, dat de schroeven ietwat eccentrisch of niet loodrecht ten opzichte van de pen worden ingebracht. Hierdoor kan de schroefdraad beschadigd worden of wordt de tegenoverliggende cortex onder een schuine hoek getroffen, hetgeen de stabiliteit niet ten goede komt. Wanneer de schroef onvoldoende houvast vindt in de cortex kan men altijd nog een door Vècsei ontwikkelde keilbout (afbeelding 45) nemen (Vècseï 1980). Het voordeel van een keilbout is, dat er een stevige verbinding tussen bout en pen bestaat, waardoor secundair losraken onmogelijk wordt. Het meest eenvoudige om losraken te voorkomen, zou natuurlijk zijn om ook de distale penopeningen te voorzien van een schroefdraad, zodat de schroeven een vaste verbinding met de pen zouden hebben. Dit is niet mogelijk omdat de diameter van de pen wisselt al naar gelang de inklemming in de mergholte waardoor er een metrische discrepantie tussen beide penopeningen bestat. Bovendien dient er enige speelruimte tussen penopening en schroef te bestaan. omdat het onmogelijk is de schroef precies in het midden van de penopening te plaatsen.

Secundair losraken van de distale schroeven kan altijd optreden (afbeelding 46), doordat het systeem voortdurend microbewegingen moet opvangen. Het feit dat er enige speling is tussen de schroeven en de penopeningen bevordert het loslaten (Kuderna 1978). Dit kan ontstaan doordat bij het inbrengen de tegenoverliggende cortex beschadigd wordt in de vorm van fijne fissuren, die ontstaan wanneer men de schroeven wil verankeren door ze er met een hamer in te slaan. Bij een localisatie van de distale schroeven in het condylenblok of de metaphyse zal het houvast minder zijn vanwege het spongieuze karakter van dit bot. Hetzelfde geldt wanneer er een ernstige osteoporose van het bot bestaat. 
losrakers van de distale schroeven.

en toegestan bij vrij dwarse enkelvoudige eratief de rotatiestabiliteil te testen en zonott statische vergrendeling over te gaan.

dynamische vergrendeling tot onvoldoende de rotatiestabiliteit peroperatief testen door $n$ of de femurkop meedratit, wanneer men been in extreme endo-en exorotatiestand

1 van de pen is het optreden wan torsie in de t meesi enge gedeelte van de mergholte pasvarus en antecurvatie wan het femur tot ean thebeweging van de pen neemt toe narmate is. Door een dunnere pen te nemen of verder Jok is het mogelijk om op deze vrijwel obligale deel van de pen te anticiperen door de pen z geven.

tvoerig en noemde het de spildrat. Wanneer formatie ontstam van de pen of van het bot. arilen zo groot is, dat zij geen deformatie toezortex perforeren of de botcylinder doen splij-

distale penopeningen zich in voor-achterwatrEen distale vergrendeling is dan niet aangeweof strekapparaat perforeren hetgeen tot syne- 


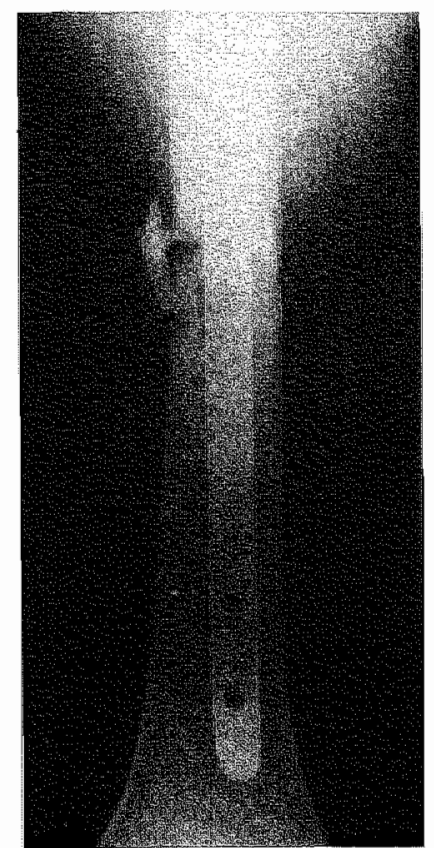

Afb. 47 De punt van de pen heaft een endorotatieabeweging van 90 gemakt, wardoor do gaten in vor-achterwartse riching werlopen. Dit is en typisch voorbedd van een pen die een spillrat heeft gemant. De oorzak ligt in thet feit dat een recht voorwerp door een gebogen kanaal gedneven wordl,

chieën kan leiden. Bij een zeer distale positie van de penopeningen beschadigen de schroeven bovendien het femoro-patellaire gewricht.

Zoals alle osteosynthesemateriaal kan ook de Grendelpen breken of buigen.

Küntscher heeft er altijd op gewezen dat een zo dik mogelijke pen genomen moest worden. Veel complicaties zijn volgens hem te wijten aan het gebruik van een te dunne pen (Küntscher 1945). Onoue (1979) berekende dat een toename van de diameter met $1 \mathrm{~mm}$ de flexiestijfheid met $14 \%$ doet toenemen. Volledige belasting bij verbrijzelingsfracturen, die door een statisch vergrendelde pen zijn gestabiliseerd, is niet mogelijk (Kempf 1978). Wanneer door gebrek aan inzicht een statisch vergrendelde pen bij een verbrijzelingsfractuur toch volledig wordt belast voordat er voldoende callusvorming is, moet dit onherroepelijk leiden tot breken wan de pen. Penbreuk treedt op die platsen op, waar krachten loodrecht op de as van de pen werken. Bijvoorbeeld daar, waar de botcylinder volledig gedesintegreerd is, zoals bij een meerfragmentfractuur of daar waar de flexiestijfheid van de pen minder is, zoals ter plaatse van de schroefopeningen. 


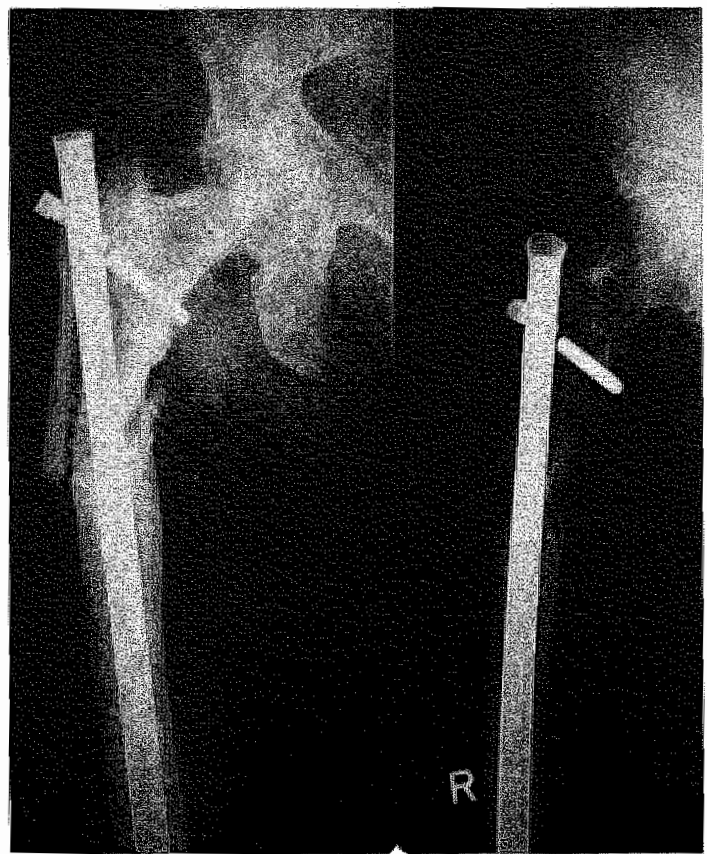

Afb. 48 Na twee maanden trad een breuk wan de proximale schroef op bij een pathologische fractuur die met een staisch vergrendelde pen was gestabiliseerd.

Schroefbreuk is uitermate zeldzaam, maar wordt incidenteel wel eens gezien (afbeelding 48 ).

De Grendelpen, die in 1968 door Küntscher werd gepresenteerd, heeft in de loop der jaren vele technische verbeteringen ondergaan waardoor een Grendelpenosteosynthese tegenwoordig routinematig kan worden uitgewoerd. Desondanks blijft

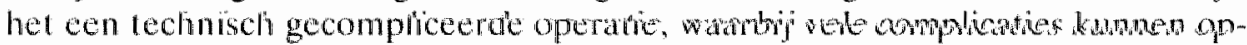
treden. 
DEEL III

HET NA-ONDERZOEK 


\section{HOOFDSTUK 7}

\section{HET NA-ONDERZOEK}

\subsection{Inleiding}

Wetenschappelijk verantwoorde uitspraken ten aanzien van de behandeling van femurschachtfracturen dienen bij voorkeur te geschieden aan de hand van prospectieve onderzockingen, waarbij vergelijkbare patiëntengroepen volgens vast protocol met verschillende technieken behandeld worden.

Met betrekking tot de meerfragment-en etagefacturen van de femurschacht is dit een moeilijke opgave gezien de relatieve zeldzaamheid van deze fracturen en gezien de snelle ontwikkeling van steeds betere osteosynthesetechnieken waardoor het toepassen van één bepaalde techniek gedurende vele jaren om een voldoende grote patiëntengroep te kunnen overzien medisch-ethisch niet te verantwoorden is. Het hoge percentage complicaties bij de behandeling van deze fracturen en de verstrekkende sociale en economische gevolgen hiervan maken retrospectieve studies zeker zinvol.

De patiënten met lemurfracturen uit twee klinieken, te weten het De Weverziekenhuis te Heerlen en de Berufsgenossenschaftliche Unfallklinik te Frankfort, werden vergeleken. Beide klinicken vervullen in hun regio een centrumfunctie wat betreft de opvang van de "zware" tratumatologie door hun meurochirurgische afdelingen. De patiënten stammen uit dezelfde tijdsperiode. Het percentage fracturen ten gevolge wan verkeersongevallen en de aari van de verkeersongevallen is in beide klinieken practisch gelijk. In de organisatiestructuur van de Berulsgenossenschaftliche Unfallklinik ligt het accent geheel op de behandeling van ongevalsletsels. Een dergelijke organisatiestructum bestaat in het De Weverzickenhuis niet, maar ook datar is de behandeling van ongevalsletsels altijd een belangrijk werkterrein voor de aldeling heelkunde geweest. Dit vond zijn oorsprong in de aanwezigheid van de kolenmijnen met hun talrijke ongevallen.

Vanal 1972 werden in de Berufsgenossenschaftliche Unfallklinik alle femurfracturen volgens vast protocol met een Grendelpenosteosynthese behandeld. De patiënten van het De Weverziekenhuis vormen eveneens een gesloten groep waarbij operatieve en niet-operatieve technieken en combinaties van beide door elkatar toegepast werden alhankelijk van de morphologie van de fractuur, het feit of cle fractuur open of gesloten was en de ervaring van de behandelend chirurg. Men dient te bedenken dat wanneer de Grendelpen niet ter beschikking staat het onmogelijk is meerfragment-en etagefracuren te behandelen volgens vast protocol omdat penen platosteosynthesen te kort schieten in hun mogelijkheden.

De resultaten van de Grendelpenosteosynthesen worden vergeleken met de resultaten die met andere technieken werden bereikt.

Vanwege de relatieve zeldzaamheid van deze fracturen worden de resultaten van de verschillende in het De Weverziekenhuis gebruikte behandelingstechnieken in zijn totaliteit vergeleken met de resultaten van de Grendelpenosteosynthesen.

Het is niet de bedoeling absolute uitspraken te doen aan de hand van deze vergelijking. De opzet van dit onderzoek is, te laten zien welke resultaten bij deze fracturen met een Grendelpenosteosynthese behaald werden. 


\subsection{Het opsporen van de patiënten}

De adressen van de geselecteerde patienten werden verkregen via het medisch archief. Alle patiënten ontvingen een brief waarin zij uitgenodigd werden om voor onderzoek naar de polikliniek te komen. Van de patiënten die niet reageerden op deze oproep, werden de adressen gecontroleerd via het bevolkingsregister en deze patiënten werden nogmaals aangeschreven.

Een beperkt zantal patiënten reageerde ook niet op deze oproep. Deze patiënten werden door de auteur telefonisch benaderd of thuis bezocht. Op deze manier konden alle patiënten, op 3 na, ertoe gebracht worden voor onderzoek de polik liniek te bezoeken $(96 \%)$. 6 Patiënten bleken ten tijde van het na-onderzoek overleden te zijn. De ziektegeschiedenis en verdere gegevens van deze patiënten werden zoveel mogelijk gebruikt.

In de periode 1974-1981 werden in het De Weverzjekenhuis te Heerlen 180 patiënten ouder dan 16 jaar behandeld vanwege een femurschachtfractuur. Via het medisch archief werden de namen en geboortedata van alle patiènten, die in deze periode opgenomen waren in verband met een femurschachtfractuur, verkregen. Met behulp van deze gegevens werden de röntgenmappen van al deze patiënten opgezocht. Aan cle hand van de morphologie van de fractuur op de röntgenfoto konden 37 patiënten ( $21 \%$ ) met 38 meerfragment-en etagefracturen geselecteerd worden. In de Berufsgenossenschaftliche Unfallklinik te Frankfort werden in de periode 1973-1981 271 patiënten met femurschachtfracturen behandeld, waarvan $52(19 \%)$ met 55 meerfragment- en etagefracturen. Deze 52 patiënten werden op dezelfde wijze als in Heerlen geselecteerd. Het tijdsbestek tussen ongeval en na-onderzoek voor alle patiënten tesamen bedroeg gemiddeld 5,75 jaar (1-10 jaar). Het patiëntenbestand kan worden opgesplitst in 52 patiënten met 55 meerfragment- en etagefracturen van het femur uit Frankfort, die behandeld werden met een Grendelpen en 37 patiënten met 38 fracturen uit Heerlen, die op diverse manieren, voornamelijk met behulp van platen en conventionele mergpennen, behandeld werden. In het onderzochte patiëntenmateriaal van het De Weverziekenhuis komen geen patienten voor die met een Grendelpenosteosynthese werden behandeld, ondat pais vanaf 1982 de Grendelpen op de chirurgische afdeling volgens vast protocol bij gesloten femurschachtfracturen wordt toegepast.

In deze studie zijn alleen patiënten boven de 16 jaar opgenomen, ondat bij jongere patiënten de groeischijven meestal nog open zijn, zodat een penosteosynthese een contraindicatie vormt vanwege het risico dat cen coxa valga ontstat ten gevolge van beschadiging van de epiphysaire vaten van de heupkop die komend vanuit de arteria obturatoria achter langs de trochanter major verlopen. (Auff'm Ordt 1975, Parsch 1981).

De patiënten werden gecodeerd. De code bestaat uit drie delen: een hoofdletter $\mathrm{H}$ of F (hetgeen betekent dat de patiënt uit Heerlen of uit Frankfort komt) en een hoofdletter die aangeeft welke techniek van behandeling gebruikt werd (Grendelpen, Küntscherpen, Conservatief, Enderpennen en Plaatosteosynthese).

Tussen beide hoofdletters geeft een getal aan om welke patiënt hel gaal. Voorbeeld: patiënt H12P wil zeggen, dat deze patiënt uit de Heerlense patiëntengroep stamt en de 12e patient uit de groep Plaatosteosynthesen is. 


\subsection{De methodologie}

Altereerst werden lijdens cen gesprek de gegewens verkregen uit statussen en polikaartengeverifieerd met de gegevens die de patient zich herinnerde.

Volgenseen vast protocol werd de palent ondervragad over:

- de ongevalstoedracht

- begeleidende letsels

- postoperatieve complicaties

- het tijdstip van partiële en volledige belasting

- de duur van de arbeidsongeschik theid, eventuele omscholing, invaliditeit

- de aanwezigheid van pijnklachten in het gebied van de vroegere fractuur en de aangrenzende gewrichten.

Na het gesprek vond het lichamelijk onderzoek plaats. Hierbij werden beide benen met elkatar vergeleken, waardoor een aantal functionele resultaten van de patienten met dubbelzijdige lemurfacturen niet gebruikt konden worden. De gewrichtsfuncties werden gemeten volgens de zogenaamde "Neutralnullmethode".

Gelet werd op:

- het looppatroon en hel gebruik van krukken, stokken en andere orthopaedische hulpmiddelen

- de stand van het bekken en de vorm van de wervelkolom

- cle beweeglijkheid van heup-enkniegewrichten

- beenlengteverschillen

- dystrophische arwijkingen

- sensibiliteit en motoriek

- rotatieafwijkingen van het femur volgens van Joost (1972)

- artericiecirculatie.

Bijelke patiént vond röntgenonderzoek van beide benen plaats, te weten een voorachterwatrtse opname volgens Spirig (1967), warrop beide benen inclusief heupen enkelgewrichten over hun volle lengte te beoordelen zijn. Bovendien werd van beide lemora een zijdelingse opname gemalkt, warop behalve de femurschacht ook het heup-en kniegewricht afgebeeld werden.

Aan de hand van deze röntgenopnamen werden de lengte van het femur, asafwijkingen in het frontale en sagittale vlak en arthrotische afwijkingen van heup-en kniegewricht bepaald.

\subsection{De overleden en niet na-onderzochte patiënten}

Ten tijde van het na-onderzoek bleken 6 patiënten overleden te zijn. 3 Patienten waren overleden tijdens hun verblijf in het ziekenhuis.

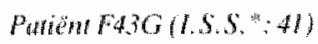

Een 19 -jarige student, die veronge lukte met zijn motor, bleck bij opname een ermstig sehedeltrauma te hebben opgelopen met intracerebrale haematomen alsmede een eerste grabs open femurfracium rechts. De dag van opmane werd de femurtractur met een Grendelpengestabiliseerd en werd patient én dag nabadema. De neurologiscthe toestand wan patiunt verslechterde geleidelijk en de zesde dag postoperaticf overked hij tengevolge van het sehedeltrauma. Bijobduct be bleken er zeer uitgebroide intracerebrale hatematomen te bestaan.

I.S.S. Injury Severity Soore 
Pariẽn $133 G(1, S .5 .41)$

Een 20-jarige motorrijder was frontaal tegen een suto gereden. Bij binnenkonst werd een dubbelzijdige temurf ractutr, een fractur van het rechter onderbeen en een ernstige longcontusie gediagnost isecerd. Alle fracturen werden a chaud voorzien van een Grendelpen en patient werd nabeddemd. Desondanks ontstond er een emstig. ARDS syndroom, waaraan patient de vijfe dag postoperatief overleed. Bij obductie werd de owerlijdensdiagnose bevestigd.

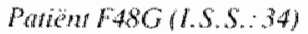

Een 49 -jarge man was als bestuurder betrokken bij een frontale autobotsing en had hierbij het stunt in de buik gekregen. Er werd bijopname cen peritoncale lawge vernicht, die negatiel was. Verder bestond er een contusio cerebri met netrologische symptomen. een open patella fractur rechts en cen gestoten femurfractur a an dezelide kant. Direet na opname werden de fracturen gestabilaseerd. Postoperatice ontstond het beeld van een pancreat tis, wa raan patiëntén week na opname overleed.

\section{Pation 1260 (1.5.5.: 16)}

Een 45-jarige wrachtwagenchauffeur reed met zijn vachtauto achter op cen andere vrachtauto. Een fomurschachtractur en een proxinale cruristraetuar beiden links werden gediagnostiseed. De dag van opname werden deze fracturen met een Grendelpen gestabiliseerd. Na 48 utur ontstond er cen ischaemic van het linker onderbeen. De gemakkte arteriografie toonde een stop ter hoogte van de arteria poplitea. Bij operatic bleek er een intimalaesie met thrombosering te bestaan. De thrombusmassa werd verwijderd en er werd een watplastiek met behulp van een veneuze patch werricht. Desondanks kon de vitatiteit van het onderbeen niet behouden worden en wond 5 weker na het ongeval cen open onderbensamputatic plats. De consolidatie van de femurschachafractuar venlicp probleemloos. De revalidatie verhiep i.w.m. de onderbeensprothese traag. zodat hij pas na 8 manden uit het ziekenhuis ontslagen kon worden. Drie maanden later overleed patient thuis. Bij obductie bleck hij onder invloed van alcohol gestikt te zijn in een grote bolus voedselresten.

\section{Paiènte HO2P (I.S.S.: 16)}

Deze wouw viel op 77-jarige leeftijd tegen de stoeprand. warbij zij ecn sterk comminutieve femurschachtfractur opliep (type C. 3.) zonder begeleidende letsets. Osteosynthese vond platuts met behulp van cen lange plaat zonder spongiosaplastiek. Na 12 maanden was het been volledig betastbaar en had patiente geen klachten meer zodat zij uit de poliklinische controle ontslagen kon worden. 5 Jaar later overleedzij.

\section{Pattërnt H14P(I.S.S.: 16$)$}

Met kegellen vicl deze man ( 56 jara) waatbij een comminutieve femurfactuur ontstond. Er werd een platostcosynthese verricht zonder spongiosaplastick. 6 Manden later presentec de patient zich op de E.H.B.O. met en refractur met platatbreuk. Er werd opnieuw een platkstcosynthese verticht, nu wel met een spongiosaplastick. Na 2 jaar werd de plat verwijderd. 2 Weken lister ontstond ten gevolge van een gering trauma een refractuur. Wederon vond een plattosteosynthese net spongiosaplast ick phats. De fractur consolideerde in 8 manden. 2 Jaar later overleed patient an een hartinfaret.

\section{Drie patiënten konden niet worden na-onderzocht:}

\section{Pathent F3/G(I.S.S.: (6)}

Deze 28-jarige man uil India werkte als gastarbeider in de bouw. Hij kwam tijdens hot werk onder een stapel stenen terecht watabij een 2-etagefractutr wan het linker femur ontstond met crnstige "crush" verschijuselen. Osteosynthese vond plats met een statisch vergendelde pen. Postoperatief waten er geen prothlemen en na 2 maanden liep patiënt volledig belast. Een jaar na het ongeval werd patient gekeurd, warbij er een goed geconsolideerde fractur met normate funclies van de aangrenzende gewrichten bleck te bestatan. Patient was ten tijde van deze studie Heruggekederd naar India.

\section{Pariante HIIP(I.S.S.: 45)}

Op 17 -jarige feeftijd werd deze vrouw als brombetsherijdster overeden door cen vrachtiuto. Nabast een

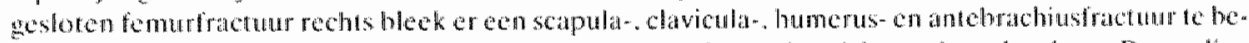
stäan alsmede een plexus brachialislacsic. Al deze letsels bevonden zich ann de recthterkant. Bovendien was er een bek kenfractuur met luxatic van het rechter sacro-ilacale gewricht en een subtotale ampulat te 


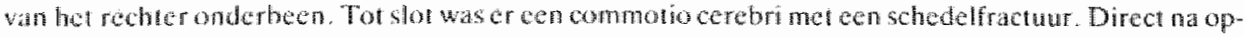
name vond amputate van het recher onderben plats en werd de fomurfractutr met een 14-gats-plaat gestabiliserd. Postoperatief ontstond er een infoctie van de operatiewond van het recher bowenbeen. Mat een productieve fistel in het littekengebied werd patiente na 2 manden mat reen revalidatickliniek owergeplaats. 9 Manden naperatie werd de plat verwijderd en werd es natologe spongosaplastiek verricht. Aarsslutend werd 2 manden tractiegegeven. Na 1 jaar was fle fractur geconsolideerd. Ondanks huisbezock weigerde patiente haar medewerking aan het nawonderzock.

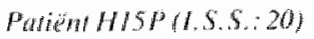

Als jongenin wan 23 jaar werongelukte deze pancon met zijn bromficts. Naust exn schedelfracturur bleek er een femurschachtfractum rechts te bestadn in combinatie met een pertrochantere fermurfractur aan dezelfle kant. De pertrochantere fractur werd met een hoek plaat gestabiliseerd en de schachtractuur met een 12-gatsplatat zonder spongiosaplastick. Na 3 maanden was de pertrochantere fracturur geconsoli-

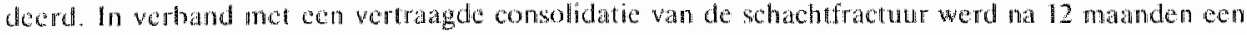
spongiosaplastick verticht, watro ook dea fractur snel consolideerde. Pariènt weigerde iedera medewerking an het na-onderzoek wit angst dat zijn W. A.O.-uitkuring hierdoor verninderd zou kunnen workten. 
DEEL IV

ANALYSE VAN HET PATIENTENBESTAND 


\section{HOOFDSTUK 8}

\section{ANALYSE VAN HET PATIENTENBESTAND}

Het patientenbestand werd gevormd door 52 patiënten uit Frankfort met 55 fracturen die allen met de Grendelpen werden behandeld en 37 patiënten uit Heerlen met 38 fracturen die met verschillende technieken werden behandeld.

\subsection{Verdeling naar leeftijden geslacht}

De leeftijdsopbouw van beide groepen was vrijwel gelijk (tabel 9 ).

In de groep behandeld met een Grendelpenosteosynthese (Frankfort) was $78 \%$ in de leeftijd 16-35 jaar. In de groep die niet met een Grendelpen werd behandeld (Heerlen) was dit percentage $70 \%$.

Tabel9 Leeftijdsverdeling

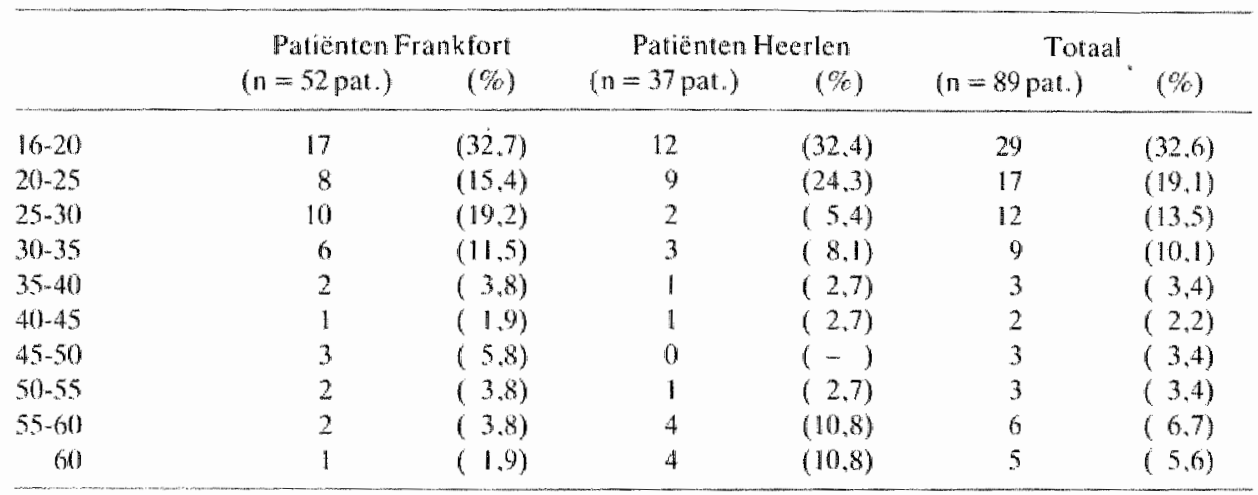

Bij de patiënten die behandeld werden met een Grendelpen was de verhouding mannen: vrouwen $81: 19 \%$. In de niet-Grendelpengroep was deze verhouding $78: 22 \%$

\subsection{Ongevalstoedracht}

De ongevalstoedracht is weergegeven in tabel 10.

Tobel lo Ongewalstoedrache

$$
\begin{array}{ccc}
\text { Patienten Franktort } & \text { Patienten Heerlen } & \text { Totaal } \\
(n=52 \text { pat. }) & (n=37 \text { pat. }) & (n=89 \text { pat. })
\end{array}
$$

Verkeer:

- auto

- motor, tromfinets

- fiets

- voctganger

Bedrijfsongeval

Ongeval thuis

33
9
0
2
5
3

11
16
1
5
1
3


$48 \mathrm{Maal}$ was het rechter femur gefractureerd en 45 maal het linker. Het percentage ongevallen bij motor-en bromfietsberijders was met $28 \%$ hoog, mar niet onverwacht. Vanaf het begin van de zeventiger jaren is er een duidelijke hausse in het motor-en bromfietsrijden. In de Verenigde Staten zette deze trend al 10 jaar eerder in (Deaner 1975, Drysdale 1975. Feldkamp 1977, Suren 1980, Böner 1982). Daar steeg van 1956 - 1976 het aantal geregistreerde motorvoertuigen op twee wielen van 400.000 naar meer dan 5 miljoen. In Nederland steeg dit aantal van 150.000 in 1950 naar 797.000 in 1982 (Centraal Bureau voor de Statistiek). De berijders van deze voertuigen zijn in het algemeen jeugdig (in deze studie gemiddeld 25 jaar).

In de series van Stapert (1983) en Kootstra (1973) waren respectievelijk $81 \%$ cn $74 \%$ van de patiënten het slachtofer van een verkeersongeval. In deze studie was dit percentage $87 \%$, daar alleen meerfragment-en etagefracturen werden meegerekend.

\subsection{Open en gesloten fracturen}

Wanneer we de fracturen verdelen in open en gesloten fracturen kunnen we naar de ernst drie gradaties onderscheiden (Müller 1977) (tabel 11).

Tabelll Openfracturen

\begin{tabular}{ccccccc}
\hline & \multicolumn{2}{c}{ Grendelpen } & \multicolumn{2}{c}{ Anderetechnicken } & \multicolumn{2}{c}{ Totabl } \\
& $(\mathrm{n}=55 \mathrm{fr})$ & $(\%)$ & $(\mathrm{n}=38 \mathrm{fr})$ & $(\%)$ & $(\mathrm{n}=93 \mathrm{fr})$. & $(\%)$ \\
\hline legrads open & 11 & $(20)$ & 3 & $(7,9)$ & 14 & $(15,1)$ \\
2e gratadsopen & 4 & $(7.3)$ & 2 & $(5,3)$ & 6 & $(6,5)$ \\
3e gradsopen & 1 & $(1.8)$ & 0 & & 1 & $(1.1)$ \\
\hline & 16 & $(29,1)$ & 5 & $(13,2)$ & 21 & $(22,6)$ \\
\hline
\end{tabular}

Het percentage open fracturen was bij Dencker (1968) 5,7\%, bij Kootstra (1973) $14,6 \%$ en bij Stapert (1983) $9 \%$. Kootstra (1973) toonde aan dat dit percentage gecorreleerd is aan het type ongeval. Veruit de meeste open fracturen ontstaan in het verkeer, vooral bij de berijders van tweewielige voertuigen. Daar $87 \%$ van de fracturen uit deze studie in het verkeer ontstond, is het niet verwonderlijk dat $22,6 \%$ van de fracturen open was. 


\subsection{Fractuurvormen}

De fracturvormen volgens Müller's indeling (afbeelding 6) zijn weergegeven in tabel 12 .

Tabel H Verdeling vande fractuturomen $(n=93$ tracturen $)$

\begin{tabular}{|c|c|c|c|c|}
\hline & $\begin{array}{l}\text { Grendelpen } \\
(\mathrm{n}=55 \mathrm{fr} .)\end{array}$ & $\begin{array}{l}\text { Andere technicken } \\
\qquad(n=38 \mathrm{fr})\end{array}$ & $\begin{array}{c}\text { Total } \\
(n=93 \mathrm{fr})\end{array}$ & $(\%)$ \\
\hline Type B.3. & 10 & 15 & 25 & $(26.9)$ \\
\hline Type C.1. & 15 & 3 & 18 & $(19.4)$ \\
\hline Type C.2. & 10 & 11 & 21 & $(22.6)$ \\
\hline Type C. 3 & 20 & 9 & 29 & $(31.2)$ \\
\hline
\end{tabular}

\subsection{Begeleidende letsels}

Om een fractuur van het femur te veroorzaken zijn grote krachten nodig. Het ligt darom voor de hand dat het aantal begeleidende letsels hoog was. Voor de Grendelpenpatiënten was de gemiddelde Injury Severity Score (I.S.S.) (Baker 1974, Bull 1982, Goris 1983) 28,7 (tabel 13). Dit is hoger dan de gemiddelde score van 14,6 in Stapert's studie (1983).

Tabel 13 Gemiddelde Injury Severity Score

Grendelpengroep $(n=52$ patiënten $)$ :

Bij $73 \%$ van de patiënten $(n=65$ patiënten) waren er begeleidende letsels; $27 \%$ van de patiënten ( $n=24$ patiënten) had geen begeleidende letsels (tabel 14). Dit percenlage is hoger dan in de series van Dencker (1963) en Kootstra (1973), waar respectievelijk $23 \%$ en $45 \%$ van de paliënten begeleidende letsels had.

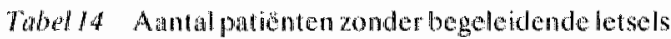

Grendelpongroep $(n=52$ pationten $)$ :

Nict.Grendelpengroep ( $\mathrm{n}=37$ patienten):

$12 \quad(32,4 \%)$

Totaal (n $=89$ patianten)

$24(26,9 \%)$

De begeleidende letsels kunnen in algemene letsels en in letsels van het homolaterale been onderverdeeld worden (tabel 15 en 16). 


\begin{tabular}{|c|c|c|c|c|c|c|c|}
\hline \multirow[b]{2}{*}{ Sehedel-hersentrama } & \multicolumn{2}{|c|}{$\begin{array}{r}\text { Grendelpen } \\
\text { groep } \\
(11=52 \text { pat }) \\
(4)\end{array}$} & \multicolumn{2}{|c|}{ 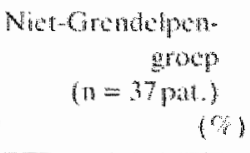 } & \multicolumn{2}{|c|}{ 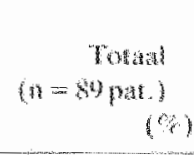 } & \multirow{2}{*}{ 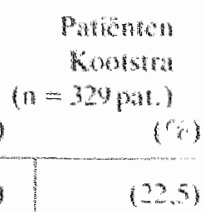 } \\
\hline & 22 & $(42,3)$ & 15 & $(40.5)$ & 37 & $(4,6)$ & \\
\hline Alodimminallotsel & $y$ & $(17.5)$ & 7 & $(18,5)$ & 16 & $(1 \times 6)$ & \\
\hline Anngezichtsfacturon & 4 & $(7.7)$ & 7 & $(1 \times 4)$ & B & $(12.4)$ & $(12.1)$ \\
\hline 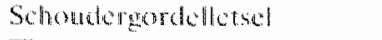 & 2 & $(3 \times)$ & 3 & $(3.1)$ & 5 & $(56)$ & $(10,0)$ \\
\hline Theroxtramal & $x$ & $(15,4)$ & 6 & $(36.2)$ & $H$ & $(15,7)$ & $(10,3)$ \\
\hline Letsel howenarm-clleboge & 8 & $(15.4)$ & 1 & $(2.7)$ & 9 & $(16,3)$ & $(5,8)$ \\
\hline Lotsoloneteram-harad & 9 & $(17.3)$ & $\$$ & $(21.6)$ & 17 & $(10.1)$ & $(4.7)$ \\
\hline Heup-bokkentatsel & 11 & $(21.2)$ & 2 & $(5.4)$ & 13 & $(14.6)$ & $(7.4)$ \\
\hline 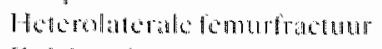 & 9 & $(17.3)$ & 1 & $(2.7)$ & 10 & $(1,2)$ & $(1.8)$ \\
\hline Knicletsel & 7 & $(1.35)$ & 4 & $(10,8)$ & $\|$ & $(12,4)$ & $(+5)$ \\
\hline Onderbeconficturer & 11 & $(21.2)$ & 15 & $(10.5)$ & 26 & $(29,3)$ & $(3 \ldots)$ \\
\hline Enkel-routcotsel & $\|$ & $(21,2)$ & + & $(10.8)$ & 13 & $(6,9)$ & $124)$ \\
\hline
\end{tabular}

Wanneer deze getallen met die van Kootstra (1973) vergeleken worden. blikt dat de patiënten met meeriragment- en etagefacturen meer ongevalstetsels vertoonden. (Alleen die patienten werden beschouwd als patiënten met een schedeltrauma, waarbij schedelfracturen en/of bewustzijnverlies en/of neurologische uitvalsverschijnselen waren opgetreden. Wanneer een laparotomie gedann werd of wanneer met radiologische technieken een intra-abdominall letsel werd vastgesteld. werd dit meegeteld als een abdominaal letsel. Onder thoraxtrauma werd verstan sternum- of ribfractu(u)r(en), haematothorax, pneumothorax, longcomusic, diafragmaruptuur, open thorax-verwonding en letsels van de medistinale structuren.

\subsection{Begeleidende letsels van het homolaterale been}

Het is bekend, dat bij een verkeersongeval of bij een val van grote hoogte ketenfracturen van het been kunnen optreden (Viernstein 1971. Voorhoeve 1973. Cusey 1979. Alho 1980). In deze studie was hel aantal begeleidende letsels van het homohaterale been anzienlijk (abel 16). In $23,6 \%$ van de gevalien was or een begeleidende homolaterale onderbeenfractur.

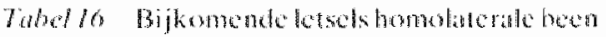

\begin{tabular}{|c|c|c|c|c|c|c|}
\hline & \multicolumn{2}{|c|}{$\begin{array}{r}\text { Grandeben- } \\
\text { grocep }\end{array}$} & \multicolumn{2}{|c|}{$\begin{array}{r}\text { Nictorendelpen } \\
\text { prace }\end{array}$} & \multicolumn{2}{|l|}{ Tolatiol } \\
\hline & $n=55 p$ & $1+3$ & $(n=38$ prat $)$ & $(\%)$ & $\left(n=4 / p_{a i d}\right)$ & $\left(r^{\prime}\right)$ \\
\hline Acettahuhumfractur & $\|$ & $(1, x)$ & 0 & & 1 & $(1.1)$ \\
\hline 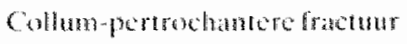 & 3 & $(5.5)$ & 2 & $(5+2)$ & 5 & $(5+)$ \\
\hline Palcuminacturar & 2 & $(7,7)$ & 3 & $(7.9)$ & 5 & $(5,4)$ \\
\hline Fonderandlotso & 1 & $(1.8)$ & 1 & $(2.6)$ & 2 & $(2.2)$ \\
\hline Onderbeantrattur & ध & $(16,4)$ & 13 & $(34.2)$ & 22 & $(2,7)$ \\
\hline Enkelfrachent & 3 & $(5,5)$ & 3 & $(7, y)$ & 6 & $(6,25)$ \\
\hline Vouthatum" & 4 & $(7.3)$ & 1 & (2.6) & 5 & $(5.4)$ \\
\hline
\end{tabular}




\subsection{Localisatie en uitbreiding van de fracturen}

Om de plats van de fractuur aan te geven, werd de femurschacht in drie segmenten verdeeld (afbeelding 7). Wanneer de fractuar meer dan én segment bestreek, werden beide segmenten meegeteld (tabel 17).

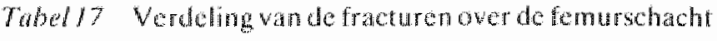

\begin{tabular}{|c|c|c|c|}
\hline & $\begin{array}{c}\text { Grendelpen } \\
\text { groep } \\
\text { un }=55 \text { fracturen })\end{array}$ & $\begin{array}{l}\text { Nat-Grendelpen- } \\
\text { groep } \\
(n=38 \text { Fracturen })\end{array}$ & $\begin{array}{c}\text { Total } \\
(n=93 \text { ractument })\end{array}$ \\
\hline Proximalc sogmena & 28 & 19 & 47 \\
\hline Middelisto segment & 46 & 28 & 74 \\
\hline Distalo sesment & 22 & 14 & 36 \\
\hline
\end{tabular}

Vrijwel alle fracturen breidden zich over meer dan één schachtsegment uit. Het middelste segment participeerde het meeste in alle fracturen.

\subsection{Opnameduur}

De gemiddelde opnameduur wordt in tabel 18 weergegeven. (De patiënten die tijdens hun verblijf in thet ziekenhuis overleden, werden niet meegerekend.) In de Unfallklinik te Frankfort werden in principe alle fracturen a chaud geopereerd en vond een groot gedeelte van de revalidatie in de klinick plaats. In Heerlen werden de femurfracturen bij voorkeur na 7 à 10 dagen geopereerd in de overtuiging dat het aantal complicaties geringer is dan wanneer men à chaud opereert (Charnley 1961, Smith 1964, Wilber 1978). De revalidatie vond bij voorkeur poliklinisch of in een revalidatie of verpleegkliniek plaats.

Tobed 18 Gemiddelde opnameduur

\begin{tabular}{|c|c|c|c|c|}
\hline & \multicolumn{2}{|c|}{ Grendelpengroep } & \multicolumn{2}{|c|}{ Niet-Grendelpengroep } \\
\hline & $\begin{array}{l}(n=49 \\
\text { patienten })\end{array}$ & $\begin{array}{l}\text { gemidd. } \\
\text { opnamedur }\end{array}$ & $\begin{array}{l}(n=37 \\
\text { patienten })\end{array}$ & $\begin{array}{l}\text { gemidd. } \\
\text { opnameduu: }\end{array}$ \\
\hline $\begin{array}{l}\text { Patticnten met goiso- } \\
\text { lecrde fomurtracturen }\end{array}$ & 12 & 27 dingen & 12 & 61 dager \\
\hline Multit roumapaticinten & 37 & 77 dagen & 25 & 90 diagen \\
\hline Totanal & 49 & 65 dagen & 37 & 81 diggen \\
\hline
\end{tabular}

De gemiddelde opnameduur van de patiënten zonder begeleidende letsels in de Grendelpengroep was 27 dagen. Bij de patiënten die met andere technieken werden behandeld, was deze periode 61 dagen. Dit is een wel zeer opvallend verschil in opnameduur ten gunste van de groep Grendelpenosteosynthesen. 


\subsection{Tijdsduur tussen opname en operatie}

In Frankfort werden alle fracturen, wanneer de patiënt in een stabiele toestand verkeerde, direct geopereerd. Dit was bij $44 \%$ van de patiënten $(n=23$ patiënten) het geval. Bij $56 \%$ van de patiënten $(n=29$ patiënten) was dit om diverse redenen niet mogelijk. Wanneer we de patiënten, die van elders overgeplaatst werden $(n=11$ patiënten), niet meerekenen dan was de gemiddelde duur tussen opname en operatie 2,9 dagen $(n=49$ patienten). In Heerlen was deze periode gemiddeld 9,2 dagen $(\mathrm{n}=32$ patiënten). (De patiënten waarvan de femurfractuur conservatief werd behandeld en én patiënte die van elders werd overgeplaatst, werden buiten beschouwing gelaten.)

\subsection{Samenvatting}

De patiënten uit Heerlen en Frankfort zijn qua leefijdsverdeling, ongevalstoedracht, fractuurvormen en begeleidende letsels goed vergelijkbaar.

Er is een duidelijk verschil wat betreft het percentage open fracturen. In Heerlen was $13,2 \%$ van de fracturen open tegen $29,1 \%$ in Frank fort. Het meest opvallende is het grote verschil in gemiddelde opnameduur. De gemiddelde opnameduur van de patiënten zonder begeleidende letsels was in de Grendelpengroep 27 dagen en in de groep die met andere technieken werd behandeld 61 dagen. 


$$
\text { . }
$$


DEEL $V$

RESULTATEN VAN DE GRENDELPENOSTEOSYNTHESEN VERSUS

DE ANDERE TECHNIEKEN 


\section{Problemen met de proximale vergrendeling}

Eénmaal lukte het slechts met zeer veel moeite om de proximale schroef in te brengen en uiteindelijk bleek deze verbogen te zijn (patient F04G: appendix casus 3). Eén keer werd de schroef niet dóor maar achter de pen geplaatst (afbeelding 43 a $t / \mathrm{m} \mathrm{d}$ ). Dit werd tijctens de operatie niet opgemerkt. Toen de patiënt het been ging belasten, trad er een verkorting op van het fractuurgebied, zodat reoperatie nodig was om de verkorting op te heffen en de schroef alsnog correct dón de pen in te brengen.

\section{Optreden van extreme spildraai}

Driemaal trad een extreme spildraai op, waardoor de distale penopeningen niet in het frontale maar in het sagittale vlak verliepen. Bij patiënt F35G (appendix casus 14) kon dit worden opgelost door een dunnere pen in te brengen. De Grendelpen bij patiënt F26G kon met veel moeite toch distaal vergrendeld worden; de schroeven werden in het sagittale vlak ingebracht en perforeerden het strekapparaat. Bij patiënt $\mathrm{F} 45 \mathrm{aG}$ vond geen vergrendeling plaats.

\section{Onvoldoende stabiele osteosynthese}

Uit de casuistiek van de patiënten F24G en F39G (appendix casus 17) blijkt, dat men de röntgenfoto's vór de operatie nauwkeurig dient te bestuderen op de aanwezigheid van fissuren in het gebied waar de schroeven worden geplaatst. In beide gevallen bleken er in het distale femur fissuren aanwezig te zijn, die praeoperatief niet waren opgemerkt. Het verlies atan stabiliteit kon worden opgelost door bij patiënt F39G na het inbrengen van de Grendelpen het gespleten condylmassief met behulp van 2 spongiosaschroeven te stabiliseren. In het geval van patiënt F24G, waar de distale schroeven door een gebied met diverse fissuren liepen en zodoende geen houvast hadden, trachtte de operateur dit op te lossen door een zestal cerclages aan te brengen (afbeelding 42).

\section{Optreden van extra fracturering}

In twee gevallen waren er problemen ten gevolge van het niet exact kiezen van de toegang tot de mergholte. Door te zeer lateraal kiezen van de toegang ontstond bij patient $\mathrm{F} 34 \mathrm{G}$ tijdens het inslaan van de pen een fractuur van de laterale cortex. Omdat de toegang te veel naar mediaal lag, liep bij patiënt F48G de punt van de pen vast op de mediale cortex. Dit werd tijdens de operatie bemerkt. Wanneer men geprobeerd zou hebben de pen met geweld toch in te brengen, zou waarschijnlijk een collumfractuur het resultaat geweest zijn. 


\begin{tabular}{|c|c|c|}
\hline & $\begin{array}{c}\text { Aantal } \\
\text { asteosymthesen }\end{array}$ & $(\%)$ \\
\hline Probiemen met de proximale vergrendeling & 2 & $(3,6)$ \\
\hline Optreden van extreme spild háali & 3 & $(5,5)$ \\
\hline Onwoldoende stabiede osteosynthese & 2 & $(3.6)$ \\
\hline Optredew van cxtra fracturering & 2 & $(3.6)$ \\
\hline Toutaal & 9 & $(16,4)$ \\
\hline
\end{tabular}

Slechts in 3 gevallen $(5,4 \%)$ konden de operatietechnische problemen niet peroperatief opgelost worden en waren zij van blijvende invloed op de stabiliteit van de osteosynthese.

\subsection{Grensindicaties voor de Grendelpenosteosynthese}

In total was bij 10 fracturen $(18,2 \%)$ een aanvulling op de Grendelpenosteosynthese nodig.

\section{Femurschachtfractuur en heupfractuur}

De combinatie femurschachtfractuur met collum- of pertrochantere fractuur kwam driemaal voor (patiënt F18G: appendix casus 8, F50G: appendix casus $23, F 52 \mathrm{G}$ ). Dit zijn osteosynthesetechnisch moeilijke fracturen wanneer men de schachtfractuur met een Grendelpen wil stabiliseren. Als osteosynthese-mogelijkheid voor de collumfractuur kan men dan alleen een aantal Kirschnerdraden of spongiosaschroeven inbrengen langs de pen. Met het Grendelpensysteem kan men een heterolaterale pen nemen, waardoor de proximale schroef schuin omhóóg in de dijbeenhals gebracht kan worden, waardoor zowel de schachtfractuur als de collumfractuur gestabiliseerd worden. Deze éne schroel biedt onvoldoende rotatiestabiliteil, maar vormt in combinatie met één of twee spongiosaschroeven een ideale osteosynthese voor dit soort gevallen.

\section{Grendelpen met cerclagedraden}

Het aanbrengen van cerclagedraden is niet in overeenstemming met het idee van de Grendelpen, maar is soms noodzakelijk bij onvoldoende stabiliteit van de osteosynthese of ter correctie van een sterke varusafwijking van de heup bij fracturering van de proximale mediale cortex (patiënt F23G: appendix casus 10 ).

\section{Vergroten distale bereik}

Indien men het distale bereik van de Grendelpen wil vergroten, kan men dit doen door extra openingen in de pen aan te brengen (patiënt F02G: appendix casus 1, F06G, F41G: appendix casus 18) of door de punt van de pen in te korten. Men dient elke opening te voorzien van een schroef omdat de openingen een verzwakking voor de pen betekenen. 


\section{Femurschachtfracturur en condylfractuur}

Wanneer een combinatie van een femurschacht fractuur en een eenvoudige fractuur van het condylmassief bestaat, kan men de condylfractuur met enkele schroeven stabiliseren en daarna een Grendelpen inbrengen voor de femurschachtfractur.

\subsection{Belasting van het been postoperatief}

Bij een statische vergrendeling kan het been direct postoperatief partieel belast worden. Berekend werd hoeveel dagen na operatie een belasting van $20 \mathrm{~kg}$ plaatsvond (het tijdstip werd alleen berekend bij die patiënten, waarbij begeleidende letsels, praeëxistente ziekten en locale of algemene complicaties geen invloed hadden op de belasting van het been). Deze periode bleek gemiddeld 18 dagen te zijn $(\mathrm{n}=$ 12 fracturen). Een volledige belasting van het been was bij deze 12 fracturen gemiddeld na 72 dagen mogelijk. Indien volledige belasting mogelijk was zonder krukken en zonder pijnsensatie werd de fractuur als geconsolideerd beschouwd overeenkomstig het voorstel van Rokkanen (1969). Röntgenologische criteria werden niet gebruikt ter bepaling van het tijdstip van consolidatie van de fractuur. Enerzijds omdat de op de röntgenfoto zichtbare callus de zogenaamde secundaire benige callus is die pas zichtbaar wordt nadat de fractuur klinisch al geconsolideerd is. Anderzijds omdat bij de met een plaatosteosynthese behandelde fracturen soms helemal geen benige callus zichtbaar wordt ondat een primaire botgenezing plaatsvindt (Wieser 1964).

\subsection{Tijdstip van dynamiseren}

39 Van de 51 statisch vergrendelde pennen werden gemiddeld na 104 dagen gedynamiseerd. Bij 12 patiënten werd de osteosynthese om verschillende redenen niet gedynamiseerd. Driemaal omdat de patiënten overleden waren (F33G, F43G, F48G), énmaal omdat de patiënt paraplegisch was en toch niet kon belasten (F24G) en bij 5 patiènten (F02G: appendix casus 1, F07G, F18G: appendix casus 8 . F25G, F40G) was er $z 0$ 'n voorspoedige fractumgenezing, dat dynamiseren overbodig was. Driemaal was vór het tijdstip van dymamiseren een re-osteosynthese noodzakelijk wegens een verbogen of gebroken pen ( $F 05 G, F 20 G, F 35 G$ : appendix casus 14).

Het tijdstip van dynamiseren is een gradameter voor de fracturigenezing: wanneer de osteosynthese gedynamiseerd kan worden, is röntgenologisch de genezing zo ver voortgeschreden, dat het been volledig belast kan worden.

\subsection{Complicaties}

\subsubsection{Zenuwletsels}

Bij 4 patienten ( $8 \%$ ) werd postoperatief een zenuwletsel vastgesteld: driemaal cen N. peroneusletsel (patiënten F26G, F39G en F50G) en éenmal (patiënt F14aG) 
een partiele laesle van de $N$. schiadicus. Twee zenuwletsels herstelden spontaan. zodat twee permanente letsels bij 50 fracturen (4\%) resteren (de kort na de operatic overleden patiönten, de dwarslaesie-patiënt en éen patiënt met een onderbeensamputatie werden niet meegeteld). Retrospectief is het moeilijk tot ommogelijk om uit te maken of deze zenuwletsels zijn ontstaan door het ongeval, tijdens de operatie of in de postoperatieve periode. Bij multitraumapatienten met dergelijke fracturen is het valk niel mogelijk om praeoperatief exact na te gaan of er een zenuwletsel bestat. De patienten werden geopereerd op de rektafel zodat door teveel tractie letsels kunnen optreden. N. peroneusletsels kunnem ook postoperatief ontstaam; voorall wanneer het been wordt vastgebonden op een slede met heup-en kniegewricht in 90 flexie is de kans op het ontstatan van een $\mathrm{N}$. peroneuslaesie ten gevolge van locale drukgroot.

\subsubsection{Posttraumatische osteïtis}

In plats van de term "diepe" infectie (Kootstra 1973, Stapert 1983) wordt in deze studie het begrip postraumatische ostejtis gehanteerd. Dit is een klinisch syndroom en als zodanig niet in enkele woorden te definiëren. Een onderscheid tussen de acute en de chronische verschijningsvorm is in deze studie niet zinvol daar beide verschijningsvormen soms niet duidelijk van elkaar te onderscheiden zijn. Vooral bij het gebruik van antibiotica kan de acute vorm geleidelijk in de chronische vorm overgaan. Het klinische beeld van de (acute) posttraumatische osteitis wordt gekenmerkt door hef optreden van algemene symptomen als koorts, leucocytose en cen verhoogde BSE en de klassieke, locale tekenen van ontsteking ter plaatse van de fractur zoals roodheid, zwelling, pijn en hyperthermie. Het duurt zeker $10-14$ dagen voordat op de röntgenfoto verancieringen van het bot, zoals ophelderingen in het gebied van het osteosynthesemateriaal en periostale reacties, zichtbaar worden. Hel belangrijkste is de bacteriologische diagnostiek. Positieve kweken uit het fractuurgebied bevestigen samen met de algemene en locale symptomen en de afwijkingen op de röntgenfoto de diagnose posttraumatische osteïtis.

Bij 4 Cirendelpenosteosynthesen $(n=52$ fracturen) trad een posttramatische osteit is op. Dit koml overeen met een percentage van $7.7 \%$ (Niet meegerekend werden de fracturen van de kort na de operatie overleden patiënten). Dit getal is hoog. Wanneer we dit percentage vergelijken met het infectiepercentage van $8.8 \%$ uit Tscherne"s serie verbrijzelingshacturen (Tscheme 1977) dan is er geen verschil. In die studie was het infectiepercentage voor alléén de platosteosynthesen $(n=127$ fracturen) $10,2 \%$. Het intectiepercentage van de Grendelpenosteosynthesen is in vergelijking met de $5,8 \%$ van Stapert (1983) bij 139 intramedullaire osteosynthesen en de $3.5 \%$ van Kootstra (1973) bij 215 operatief behandelde femurfracturen niet slecht. Men dient namelijk te bedenken dat in deze studie alleen meerfrägment-en etagefracturen werden meegeteld, warbij het weke delen trama in vele gevallen uitgebreid was en he percentage open fracturen $29,1 \%$ bedroeg. De ziektegeschiedenissen van de patiënten met een posttraumatische osteïtis waren als volgt:

1. Pattënte $\mathbf{2 3 0}$ (appendix casus 10$)(1.5 .5$ : 48$)$, cen vrouw vam 30 jata. werd als voetgangster angereden dwor ten auto. Zij hep een dubbelzijdige bekkenring tractuur op alsmede cen blatsuptuur. cen commotio cerebri on ecn cersto graads open 2 etagefractur van het linker femur. Na éca dag werd zij owergeplantst natr de Unfallklinik te Frankfort. De blastuptuar was gering en kon conser- 


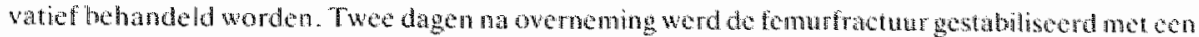
statisch vergrendelde pen en 4 cerclagedraden. 18 Dagen postonerat tief werd cen wondabees gedril neerd (Staph. aureus) in het operatiegetied. 36 Dagen postoperathef vond een sequesterctomic plats on werd ben cerclagedratad verwijerd. Een tweede sequesterectomie was 92 dagen later noodzakelijk warbj de drie resterende cerclagedraden werden verwijderd. Wegenseen vertangde botgenezing werd aa 148 dagen cen autologe spongiosaplastick verricht. In verband net can herop-

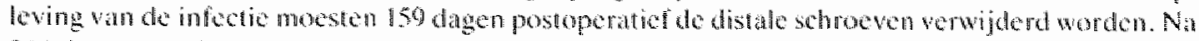
264 dagen werd opmicuw ecm autologe spongiosaplastick verticht. 15 Manden postoperatiof werd

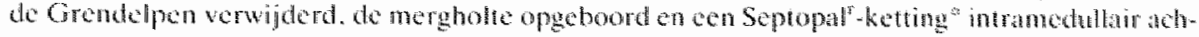
tergelaten. Ondat de callusvorming nog seeds gering wasen cen refractur dreigde. He rd cen lixateur externe angebracht en tevens voor de derde mal cen spongiosaplastick verricht. A Marandin

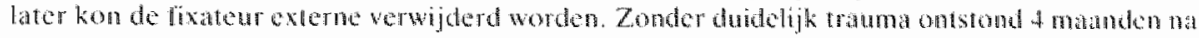
het verwijderen val de fixateur externe en refractutr, zodat opnicuw een lixateur externe yeplatst moest worden. Een half gat later kon deze worden verwijderd nadat de fractur met cen gocde callusvorming was genezen. Patrënt heeft danna geen tekenen van osteitis meer getoond.

2. Patient F20G, (appendix casus 13) (I.S.S.: 34), cen 17-jarige man, reed met zijn moror frontat tegen een anto. Hij bleck bij birnenkomst in het zekenhuis derdegraads open fraeturen wan rechter boven-en onderbeen opgelopen te hebben alsmede een "deglovement" verwonding van de reeluer hiel. De wonden werden behandeld en opengelaten en aansluitend werden boven en onderbeen gestabiliseerd met oen fixateur exteme. Postoperatief werd wegens tekenen wan ischacmic een arterion. grafie van het rechter been gemaakt, watrop geen afwijkingen zichtbaar waren. Enkele dagen later werden de voet en her distale onderbeen gangraeneus, zodat na zes dagen een open amputate van het onderbeen werd uitgevoerd. De wonden a het bevenbeen genazen voorspoedig. Daar pattient met een fixateur exterve op het femur geer prothese angemeten kon krijgen. werd besloten de fixateur externe te verwijderen en de fractuur te stabiliseren met een statisch vergrendelde pen. Dit wond 36 dagen na opname plaats. 6 Dagen postoperatief werd op verdenking van infectie de wond geopend. Er kon geen manifeste infectie worden vastgesteld zodat de wond over een Sepropal'-ketting werd gesloten. Na 5 manden werd patiènt heropgenonen voor het verwijderen van de distale schroeven. Deze bleken ten gevolge van een "low-grade" infectie los te zitten. De distate schroeven werden verwijderd en de wond werd gesloten over een Septopal ${ }^{\mathrm{T}}$-ketting. De Grendelpen kon na 10 maanden verwijderd worden. Na genezing van de wond werd 2 maanden later een spongiosaplastick verricht. Patient heeft tot op heden geen recidief osteit is doorgemaakt. Retrospectief lijkt het niet raadzaam om direct na het verwijderen van en fixateur externe een Grendelpen in te brengen, ondat er in de pin-track's van de pennen een "low-grade" infectie bestaat. In zo"n geval is hel beter na het verwijderen van de fixateur externe enkele weken te wachten totdat de boorkanalen rustig zijn. De pattient dient dan onder uitgebreide amibiotische prophylaxe geopereerd te worden (Ahlers 1983).

3. Patient F35G (appendix casus 14) (I, S.S.: 29), cen jongeman wan 18 jatar, was als bestutuder van con auto betrokken bij een frontale botsing. Hij werd opgenomen met cen tweedegradis open femurfractuur links, een commotio cerebri en een kniebandle tsel rechts. De day van opneming werd de fomurfractuurgestabiliseerd, waabij een statisch vergrendelde pen werd ingebracht. Dric gedevitaliseerde botfragmenten werden bij de operatic verwijderd. Na b dagen werd ecn geinfectecral hasematoom ontlast en werd cen Septopal' "ketting ingebracht waarna het wondgebied tot rust $k$ wam. 25 Dagen postoperatief was een spongiosaplastick gepland. Bij operatic toonde het wondgebied nog tekenen van intectic, zodat een nieawe Septopal ${ }^{5}$-kettiog werd ingebracht. De geplande spongiosal plastiek vond 7 manden later plats. Na 1.3 maanden werd patient heropgenomen omdat de Grendelpen op rwee platatsen gebroken was en ereen hyperthrophepseudarthrose was ontstatan. Een dikkere Grendelpen werd ingebracht, die dynamisch vergrendeld werd: bovendicn werd cen autwoge: spongiosaplastick verricht. $1 \%$ Jaar nad deze laatste operatic was de fract tur in goede stand geconsolideerd.

4. Patient F38G (appendix casus 16) (I.S.S.:29), een 27 jatrige marn, reed met zijn auto frontaal legen een muur. Hij liep hierbij een gesloten femurfractuar rechts op. alsmede cen commotio cerchi de n thoraxtrauma met ribfracturen en een pneumothorax aan de rechter kant. Hij werd meteen geopereerd watarbij via de gestoten operatietechniek een statisch vergrendelde pen werd ingebracht. 2u Dagen postoperatiof werd een wondabces in het operatiegebied gedramecrd, watra een fistel ont-

* Septopal $=$ gentamycine $\mathrm{PMMA}$ 
stond. 3 Manden bater werd een sequesterectomic en een spongiosaplastiek verricht. 2 Maanden daarna wend de Grendetpen verwijderd, de merghole opgeboord en werd een Septopal' keming intramedullair achtergctaten. Zondef adequat trăuma kreeg patient 3 maanden na het verwijderen wan de pen een refractur die met een heupspica wan gips werd behandeld, warna de fractuur in 4 maranden consolideerde.

Bij deze 4 patiënten met een posttraumatische osteitis was er tweemaal sprake van een vertraagde botgenezing. 14 Extra ingrepen waren bij deze 4 patiënten nodig om de fracturen tot consolidatie te brengen, te weten: $7 x$ abcesdrainage, $4 x$ spongiosaplastiek, $1 x$ sequesterectomie en $2 x$ een re-osteosynthese.

De posttraumatische osteit is kon bij deze patiënten tot genezing worden gebracht voorzover men tenminste bij een posttraumatische osteittis van definitieve genezing mag spreken. Ten tijde van het na-onderzoek waren bij geen van de 4 patiënten tekenen van een chronische posttraumatische osteitis aanwezig.

\subsubsection{Reïnterventies}

Bij 4 van de 52 osteosynthesen $(7,7 \%)$ was een re-osteosynthese noodzakelijk (tabel 21) (Niet meegerekend werden de fracturen van de kort na de operatie overleden patiënten). Tweemaal was een re-osteosynthese noodzakelijk omdat de Grendelpen verbogen was na een val. Bij deze patiënten werd énmaal een re-osteosynthese verricht met een Grendelpen (patiënt F20G) en éenmaal met een Küntscherpen (patiënt $F 05 \mathrm{G}$ ). Bij patiënt $\mathrm{F} 23 \mathrm{G}$ (appendix casus 10 ) werd in verband met een post traumatische osteit is de Grendelpen vervangen door een fixateur externe. Wegens een pseudarthrose met penbreak werd bij patiënt F35G (appendix casus 14) een nieuwe Grendelpen ingebracht en een spongiosaplastiek verricht. Patiënt F02G (appendix casus 1) onderging niet direct een re-osteosynthese maar vanwege een verkorting van $6 \mathrm{~cm}$ werd een verkortingsosteotomie van het andere been uitgevoerd. Patiënt F38G (appendix casus 16) met een posttraumatische osteïtis liep nat her verwijderen van de Grendelpen een refractuur op welke met een bekkengips werd behandeld.

Tabel2l Reinterventies na Crendelpenosteosynthesen $(n=52$ fracturen)

1. Patient F05G:

Grendelpen verbegen

2. Patien Pog:

Grendetipen verthogen

3. Pationt Fas:

postraumatische osteints

4. Pation F2\%:

postramanitischeosicitis

5. Parition F35:

posttraumatische osteitis

$\rightarrow$ re-nsteosynthese: Küntscherpen

$\rightarrow$ re-osteosynthese: Grendelpen.

$\rightarrow$ pseudarthrose $\rightarrow$ re-osteosynthese: fixateur cxtome + spongiosaplastick.

$\rightarrow$ vertrangde consolidatie $\rightarrow$ spongiosapliastiek.

$\rightarrow$ vertragde consolidatie $\rightarrow$ spongiosiaplastiek $\rightarrow$ pseudarthrose + penbreuk $\rightarrow$ re-osteosynthese:

Grendelpen + spongiosaplastiek.

6. Palienat F3gG:

postraumatische osteit is

$\rightarrow$ vertraigde consolidatic $\rightarrow$ sequesterectomie + spongiosaplastick. 
In de groep Grendelpenosteosynthesen was de primaire operatie 6 man $(11,5 \%)$ niet voldoende om de fractuur tot consolidatie te brengen.

\subsubsection{Vertraagde botgenezing}

Wat betreft het percentage fracturen met een vertraggde botgenezing in een bepaalde serie speelt het beleid ten aanzien van de open fracturen een belangrijke rol: behandelt men deze fracturen al dan niet met een penosteosynthese en zo ja, doet men dit dan à chaud of pas na genezing van de weke delen? Men dient zich bij do primaire behandeling te allen tijde te realiseren, dat een fractuur met en vertragde botgenezing ten gevolge van een infectie uitermate moeilijk te behandelen is en een zeer lange lijdensweg voor de patiënt betekent (Klemm, Junghans 1976). Eenderde deel van de geinfecteerde femurpseudarthrosen uit het materiaal van Müller (1979) was terug te voeren op open femurfracturen. De periode vanaf het ongeval tot de genezing van de pseudarthrose was gemiddeld 27 maanden welke periode de patienten grotendeels in het ziekenhuis doorbrachten en gedurende welke periode gemiddeld 5,2 ingrepen verricht werden (Müller 1979).

Evrard (1971) berichtte over de behandelingsresultaten van 55 geinlecteerde femurpseudarthrosen. In 19 gevallen moest worden overgegaan tot amputatie van het been. Bij de uiteindelijk genezen pseudarthrosen resteerde meestal ernstige schade aan de weke delen met sterk functieverlies van heup-en kniegewricht.

In deze studie trad bij 4 patiënten, die met een GrendeIpen behandeld werden, een vertraagde botgenezing op ten gevolge van een posttraumatische osteitis. Bij 3 van de 4 patiënten bestond er een open fractuur. Van ongeval tot genezing duurde gemiddeld 23,8 maanden (16-29 maanden). Tsicherne (1977) sprak van een vertraagde botgenezing wanneer de fractuur na 24 weken nog niet geconsolideerd was. Wanneer dit na 8 maanden nog niet het geval was, sprak hij van een pseudarthrose. In de moderne operatieve fracturbehandeling is er geen duidelijk verschil tussen de begrippen vertraagde botgenezing en pseudarthrose behoudens de tijd die verstreken is vanaf de operatie, omdat bij een vertragde botgenezing tegenwoordig al snel operatief wordt ingegrepen en men niet wacht totereen "klassieke" pseudarthrose met pen-of platbreuk is ontstan. Het is derhalwe niet zinvol in het kader van deze studie een onderscheid te maken tussen beide begrippen. Wanneer de fractuun na 24 weken niet is genezen, wordt dit beschouwd als een vertraagde botgenezing.

In deze studie was er bij alle 4 tracturen, waabij een postraumatische osteïtis (patienten F23G, F25G, F35G, F38G) optrad, sprake van een vertragde botgenezing. De fracturen van de patiënten F05G en F20G, waarbij de Grendelpen verbogen was, toonden beide na de re-osteosynthese een voorspoedige fractuurgenezing binnen 24 weken vanaf het ongeval. Het percentage fracturen met cen vertragde botgenezing was met 4 uit 52 fracturen $7.7 \%$ (Niet meegerekend werden de fracturen van de kort na de operatie overleden patiënten). Bij de Grendelpenosteosynthesen zonder posttraumatische osteit is trad geen vertragde botgenezing op. Slapert (1983) vond in zijn studie ( $n=139$ intramedullaire osteosynthesen) in $3,5 \%$ van de gevallen een vertragde botgenezing. In Tscherne's (1977) serie verbrijzelings fracturen was dit percentage $28,1 \%(n=160$ osteosynthesen $)$. Voor do platosteosynthesen $(n=127$ plaatosteosynthesen) was dit percentage in die serie $34,6 \%$. Men 
kan hieruit concluderen dat uit oggpunt van pseudarthrose-"preventie" de Grendelpentechniek duidelijk voordelen biedt boven de platosteosynthese. Het percentage van $7,7 \%$ fracturen met een vertraagde botgenezing in deze studie is erg laag in vergelijking met de percentages die in de literatuur worden opgegeven bij de behandeling van femurfracturen met conventionele mergpennen. Deze percentages variëren namelijk van $0,6 \%$ tot $31 \%$ (Eid 1980 ).

\subsection{Samenvatting}

Resumerend blijkt dat $43,6 \%$ van de Grendelpenosteosynthesen via de open operatietechniek werd verricht en $56,4 \%$ via de gesloten operatietechniek.

In $92,7 \%$ van de gevallen vond een statische vergrendeling plaats tegen $7,3 \%$ dynamische osteosynthesen.

Tijdens $16,4 \%$ van de operaties traden technische problemen op, die van invloed waren op de stabiliteit of de repositie, zoals problemen met de proximale vergrendeling, het optreden van een extreme spildraai van de pen, het niet bereiken van een voldoende stabiele osteosynthese en het veroorzaken van extra fracturering. $10,9 \%$ Van deze technische problemen konden tijdens de operatie opgelost worden of waren niet van invloed op de stabiliteit.

De patiënten zonder begeleidende letsels konden het been gemiddeld na 18 dagen partieel en na 72 dagen volledig belasten.

Na gemiddeld 104 dagen werden de statische osteosynthesen gedynamiseerd.

Postoperatief waren er $8 \%$ zenuwletsels, waarvan $4 \%$ reversibel bleek.

In $7,7 \%$ van de gevallen ( 4 osteosynthesen) was er sprake van een posttraumatische osteïtis. Deze vier osteïtiden konden met 14 extra operaties tot genezing worden gebracht.

Bij 6 osteosynthesen $(11,5 \%)$ was de primaire operatie niet voldoende om de fractuur tot consolidatie te brengen: 4 maal i.v.m. een posttraumatische osteïtis en 2 maal wegens een verbogen pen.

Bij alle 4 fracturen met een postraumatische osteitis was er sprake van een vertraagde botgenezing. De overige osteosynthesen toonden geen vertraagde botgenezing.

\subsection{Appendix}

Het verloop van de fractuurgenezing bij 23 patiënten aan de hand van de röntgenfo10 s. 


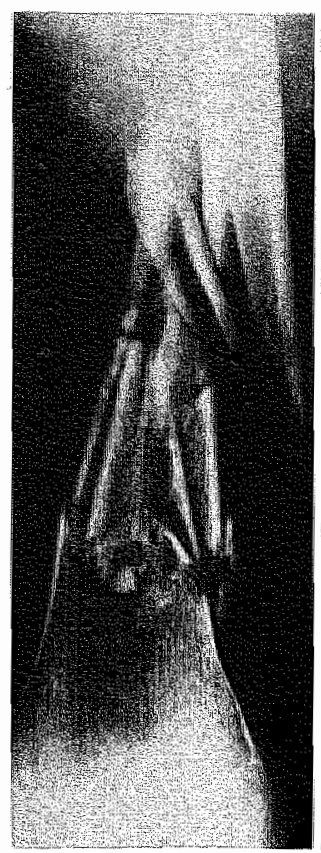

a
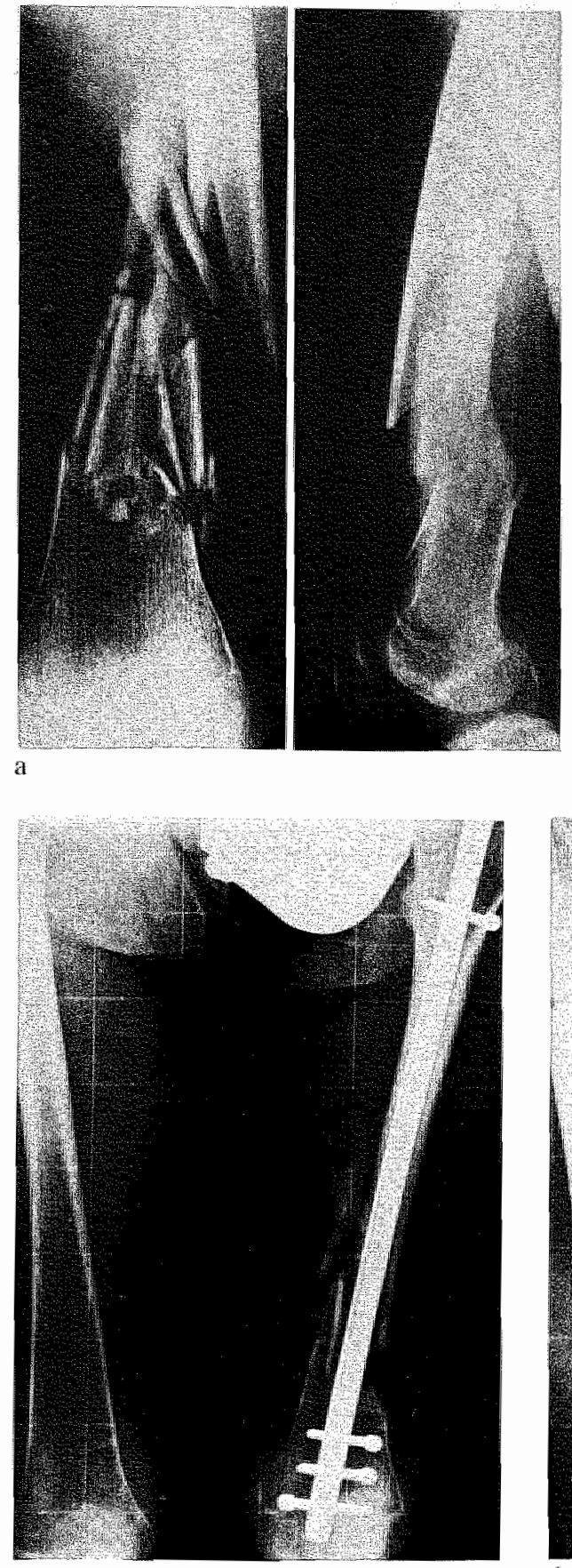

c

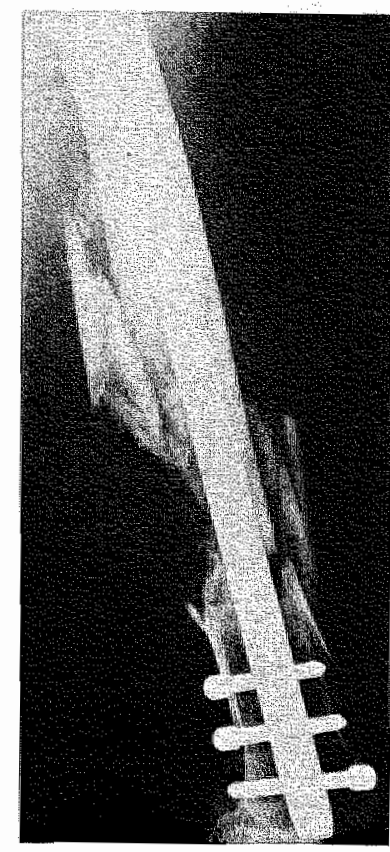

b

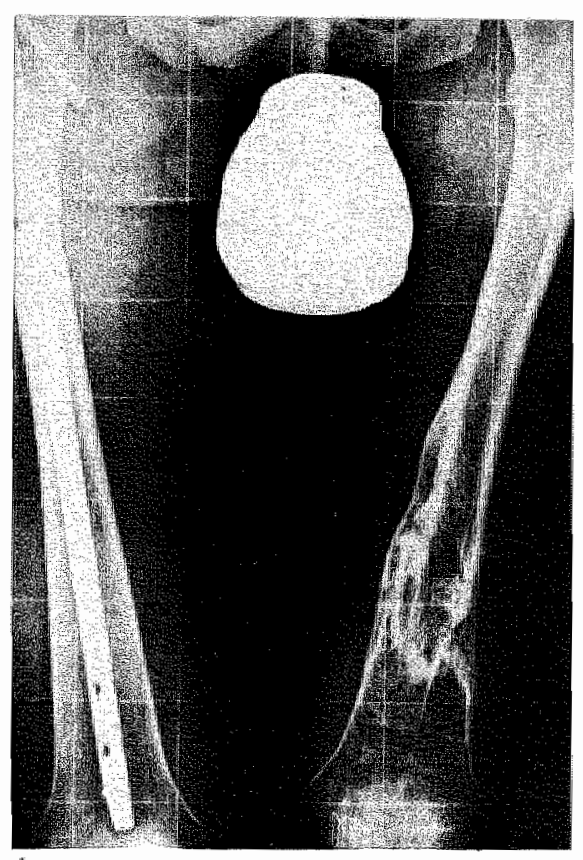

d

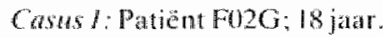

Twedegrads open femurfracturlinks, type C.3., ren gevolge wan ecn mororongeval.

a. Röntgentoto s bijopname.

b. Eon week napopratie.

c. Eén mand na operatie. Op deze foto is te zien dat ten gevolge van de osteosynhese exn exheme verkorting van thet linker femur is opgetreden.

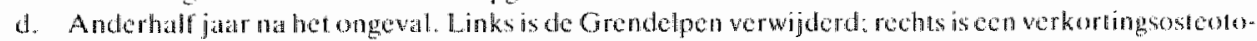
mie werioht. 


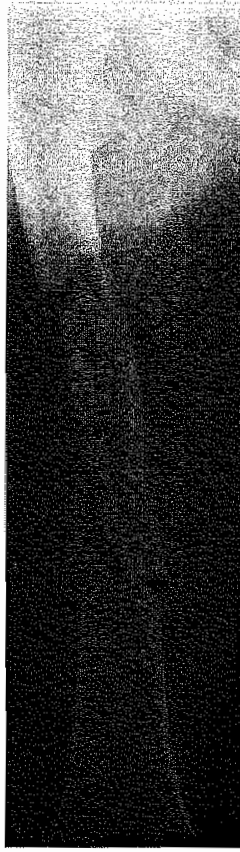

a

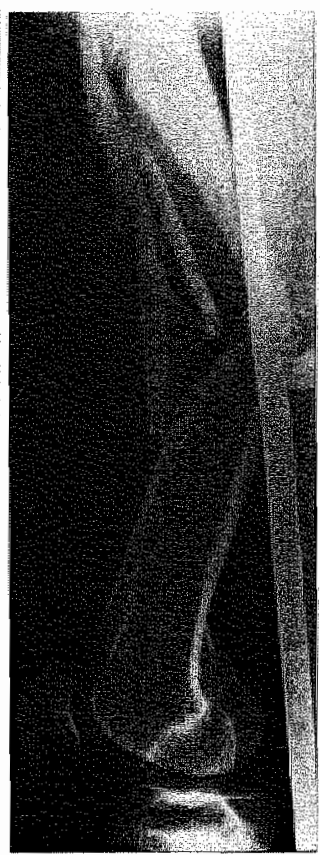

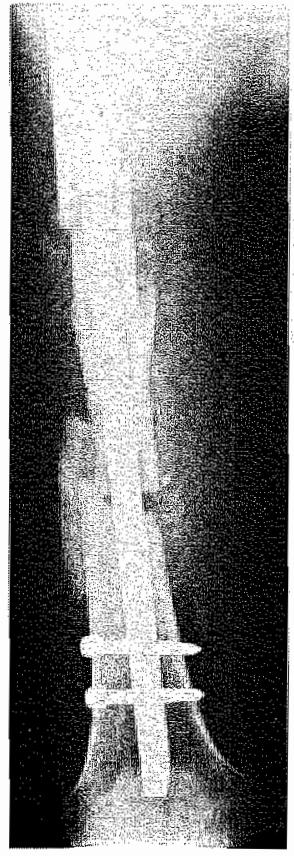

b)

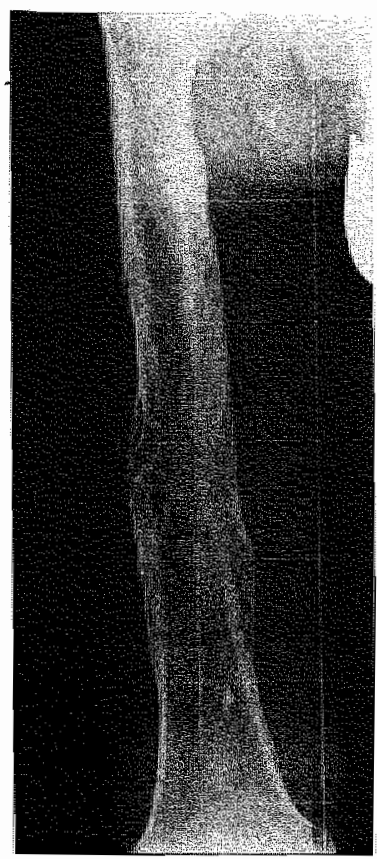

c

Custh 2: Palient F030; 29 jant.

Gesloten femurfracteur rechts, type C. 3 , ontstan doordat een boom op het been was gevallen.

i. Röntgenfoto simjopnane.

b. Eénmand na operatie.

c. Röntgenfoto naverwijderen van het osteosynthesematerial twee jan postoperatief. 


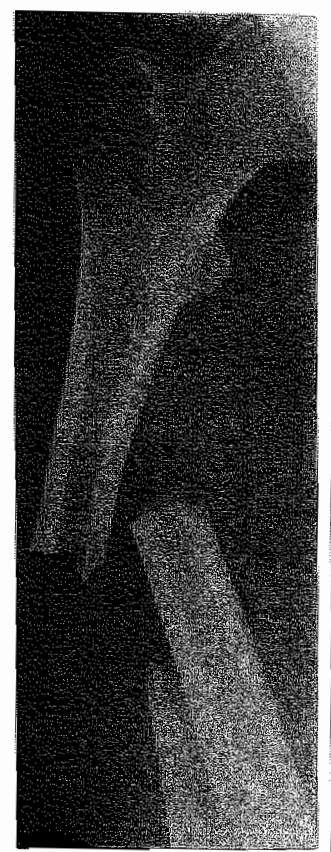

a

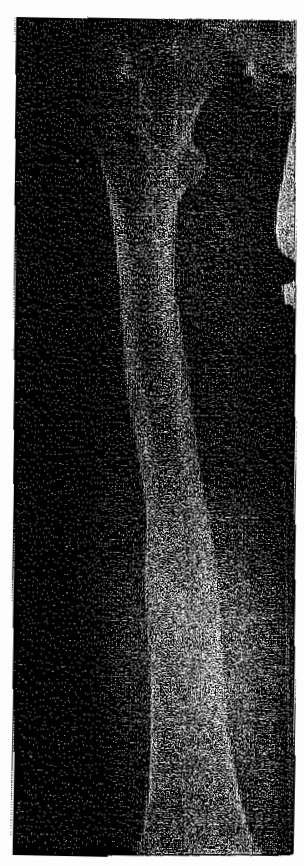

c
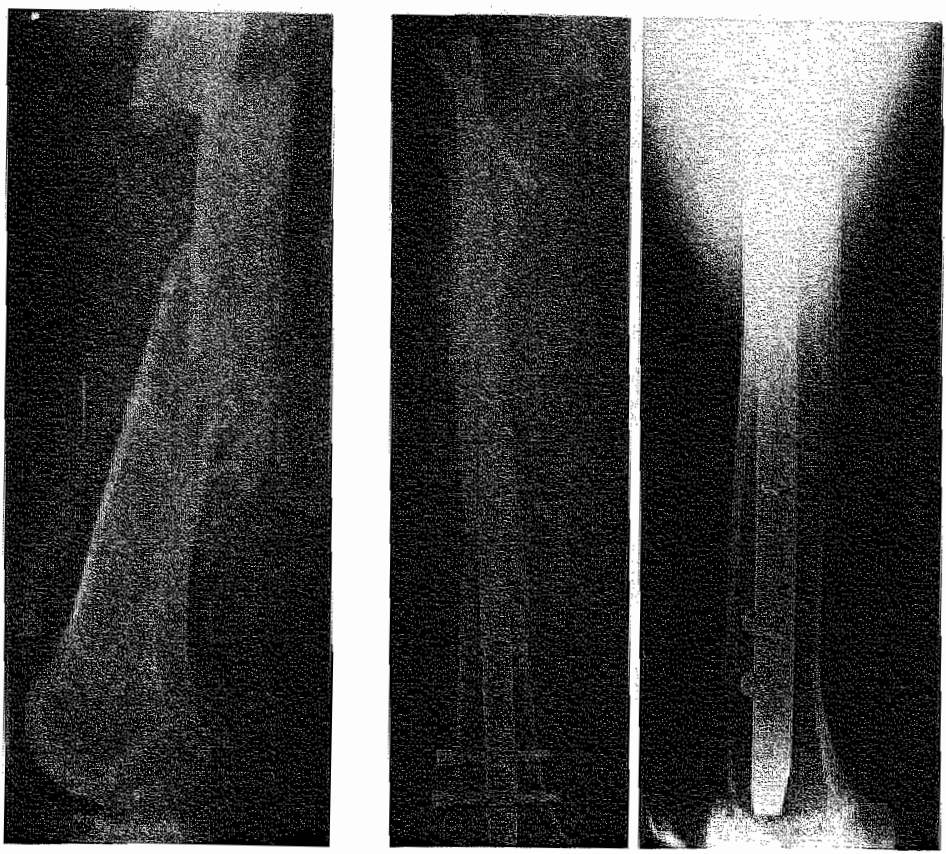

b

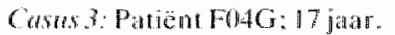

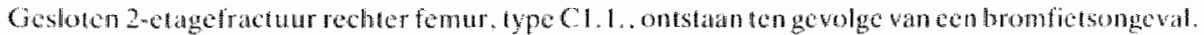

a. Rombenfoto's bijopnana.

b. Twe wekenpostoperatief.

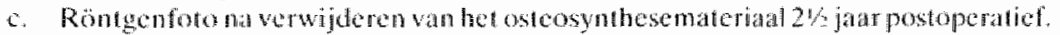




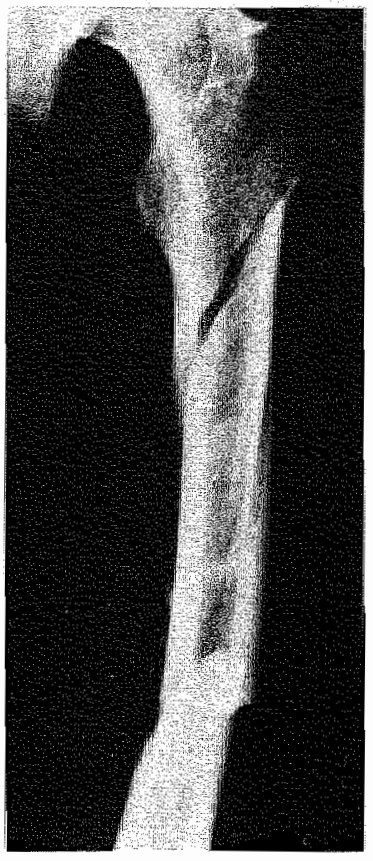

dil

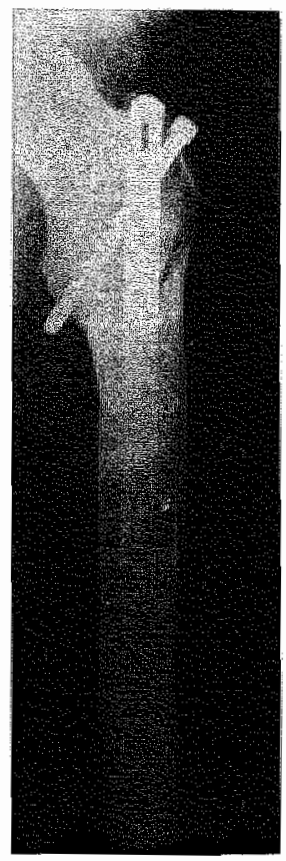

b

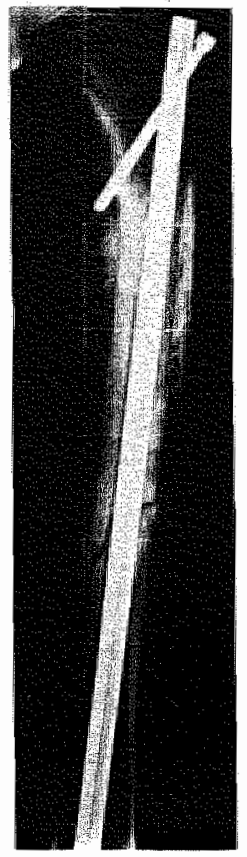

0

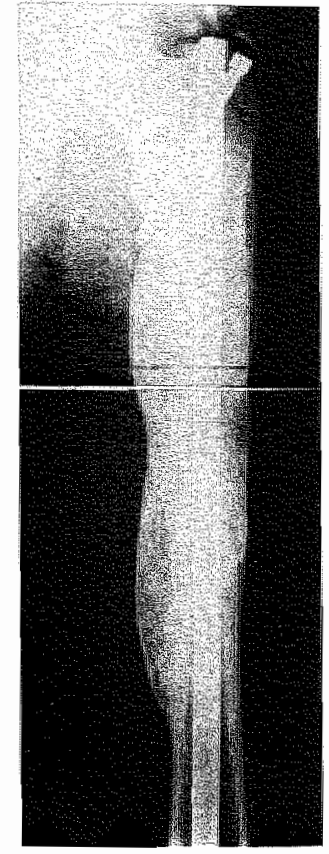

d

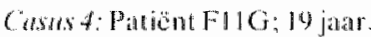

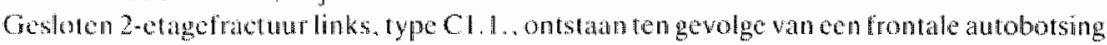

i. Röntgenloto bijopname

b. Ditectpostopetaticer.

c. Two matadon postoperatice.

c. Een jäa postoperitiof. 


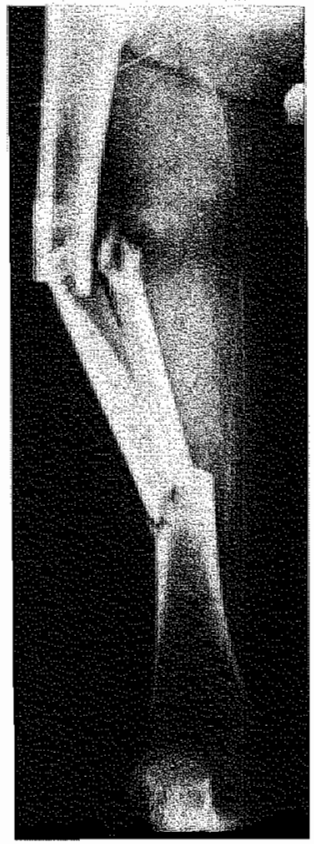

a)
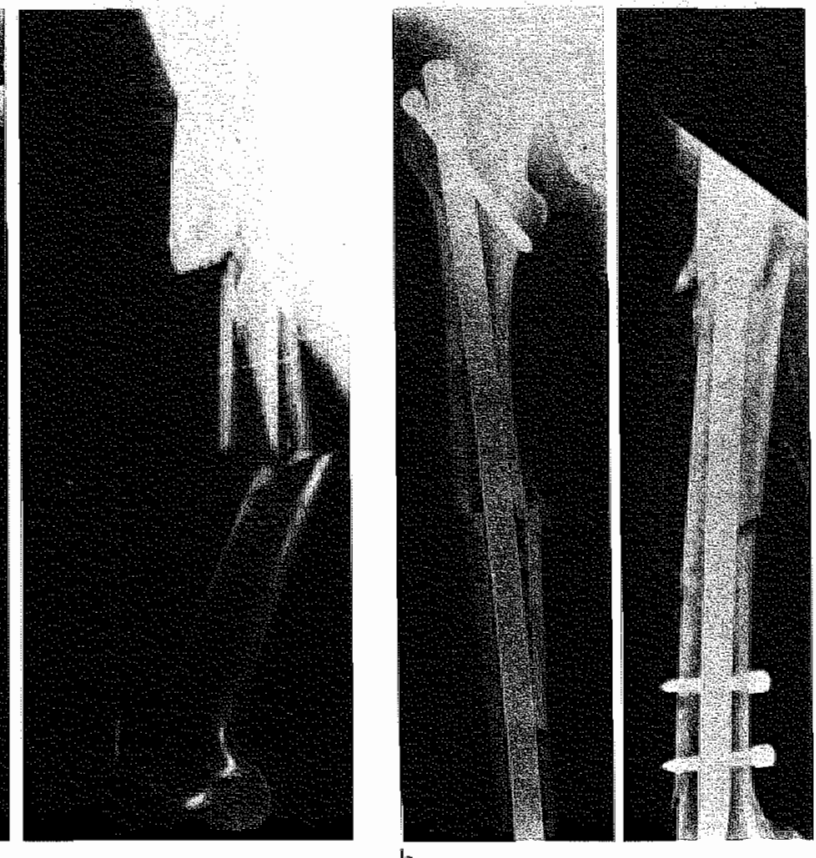

b
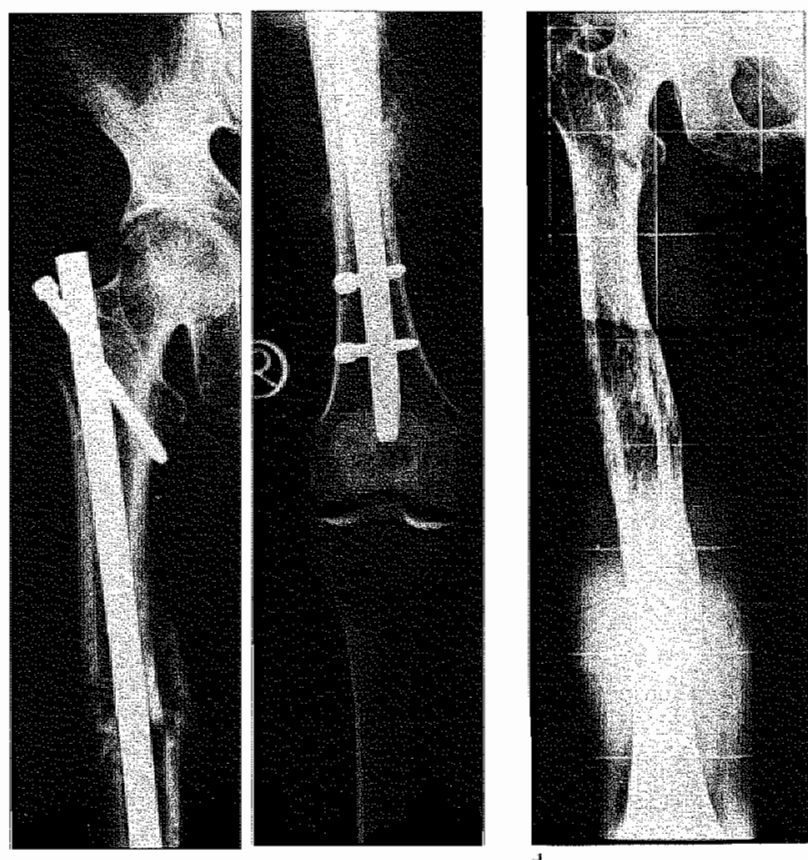

c

$d$

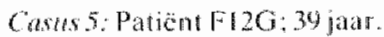

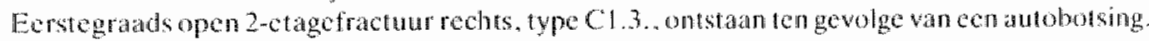

a. Rontgenfotosbijopname.

b. Direct postoperattief.

c. Vijf manden postoperatiol

d. Zeven jasr postoperatiof. 


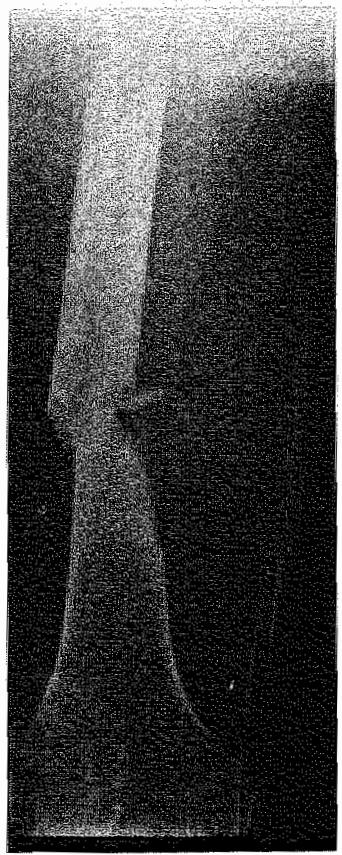

tit
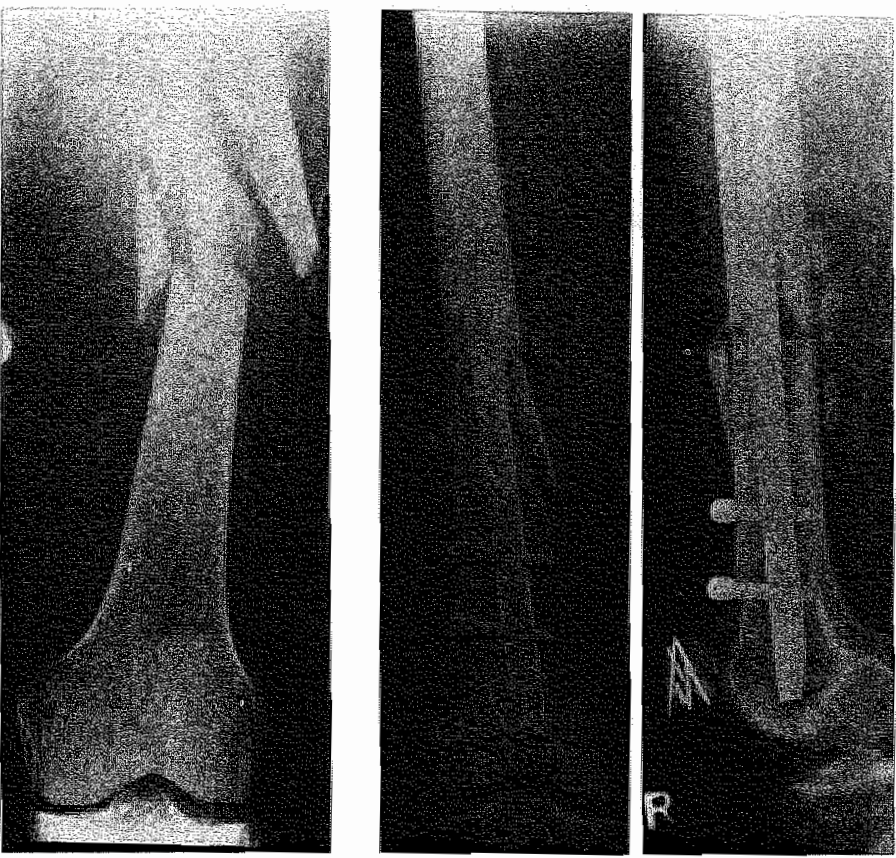

b

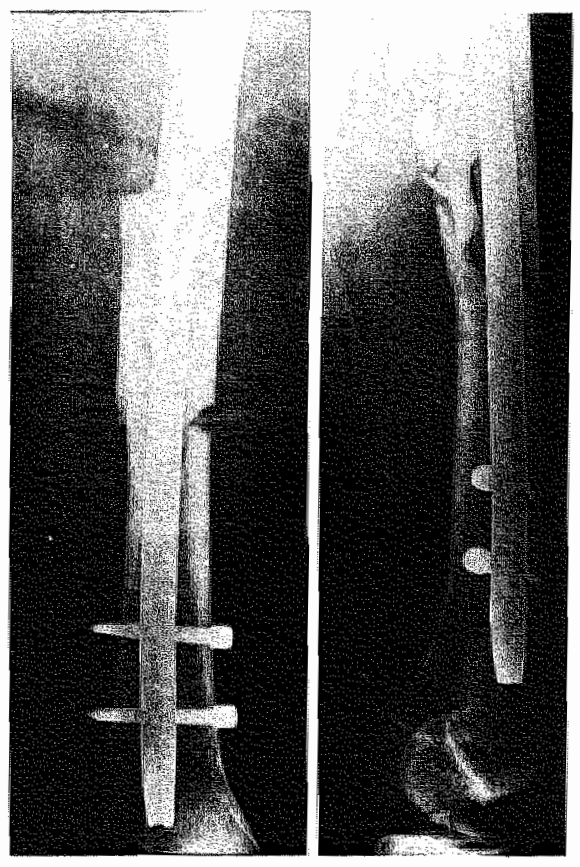

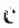

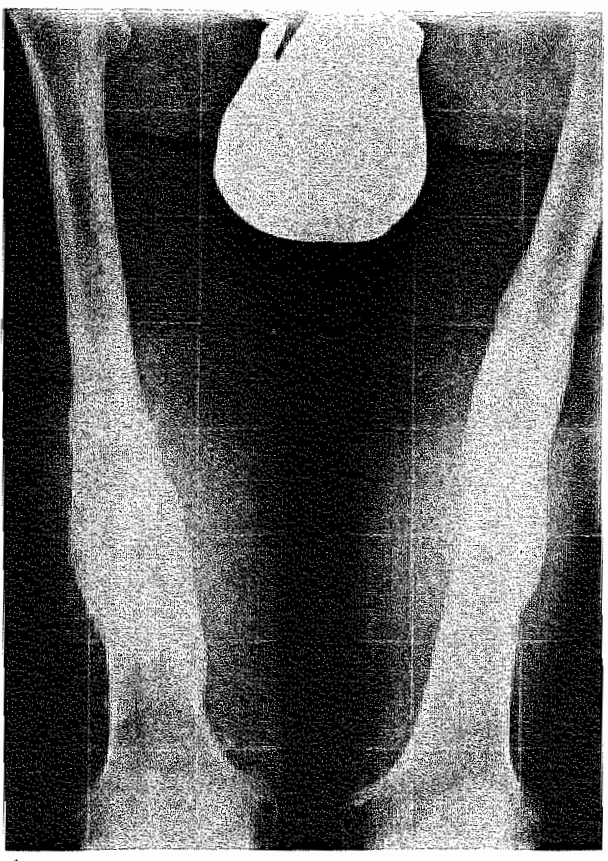

d

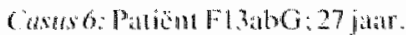

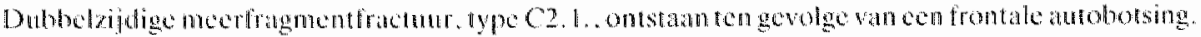

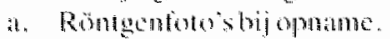

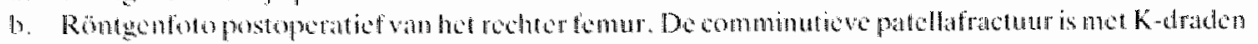
golixicun.

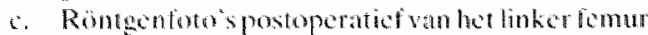

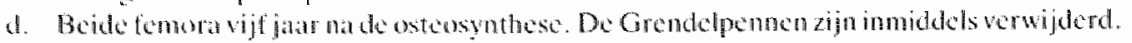




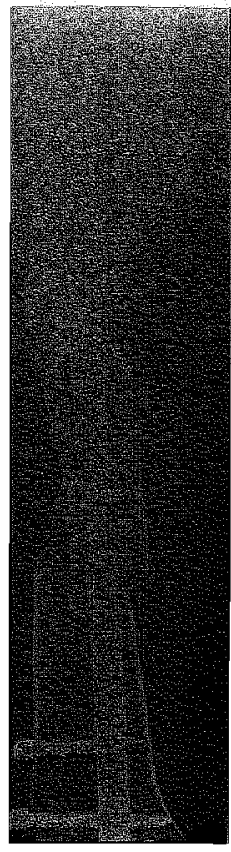

a

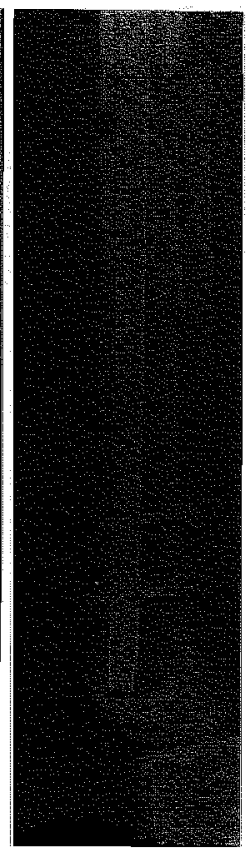

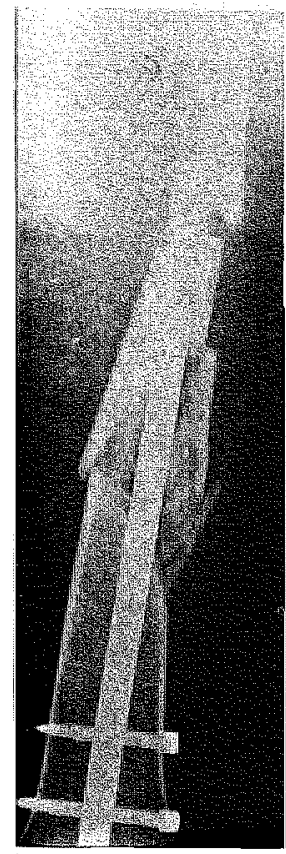

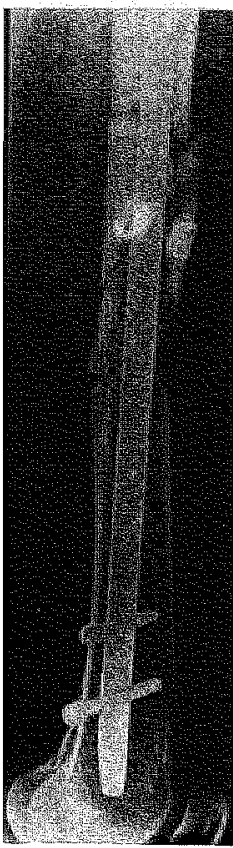

b
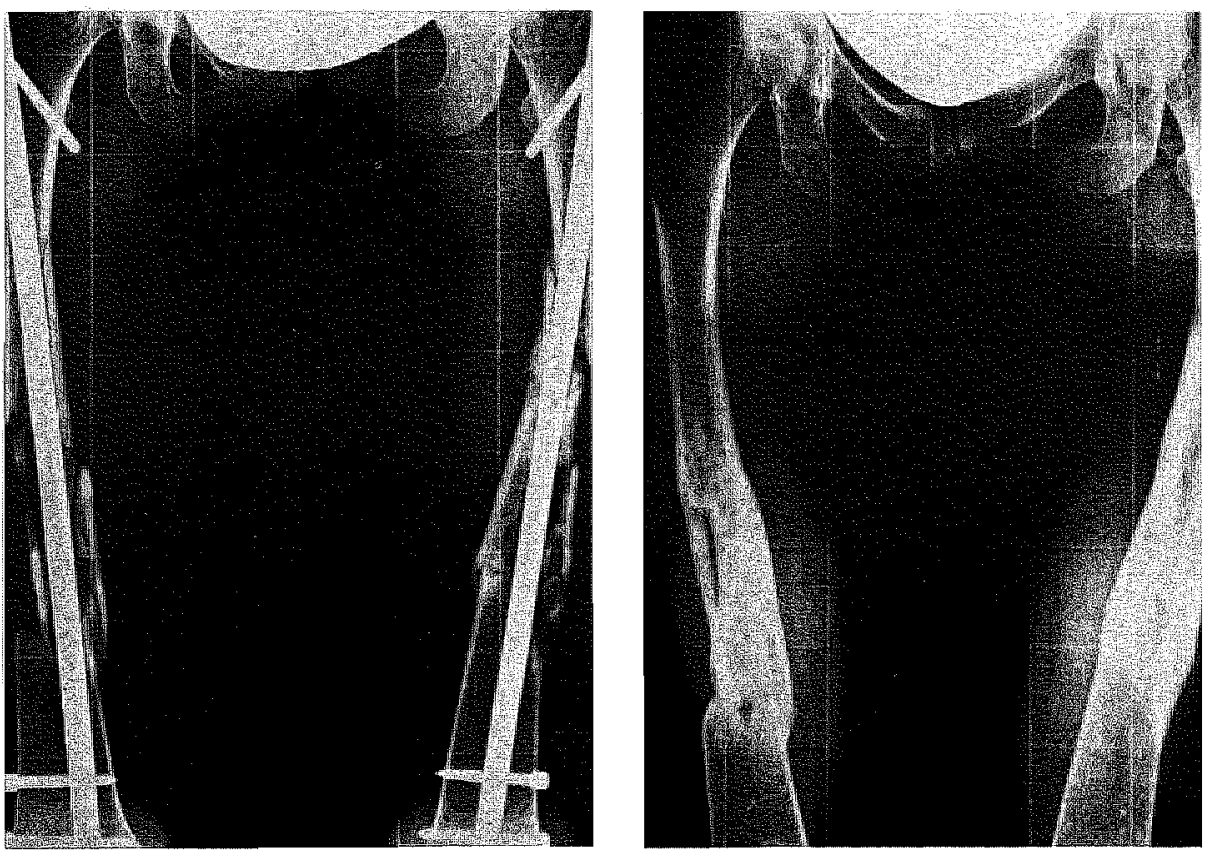

(1)

Casus 7: Pattënt F14abG; 19 jaar.

Dubbelzijdige mecrfragmentractuur. type C3.2., ontstatan ten gevolge van een frontale autobotsing.

a. Rechter femur direct postoperatief.

b. Linker femur postoperaticf.

c. Beide femora drie manden postoperatief.

d. Beide femora zes jaar na het ongeval. De Grendelpennen zijn verwijderd. 

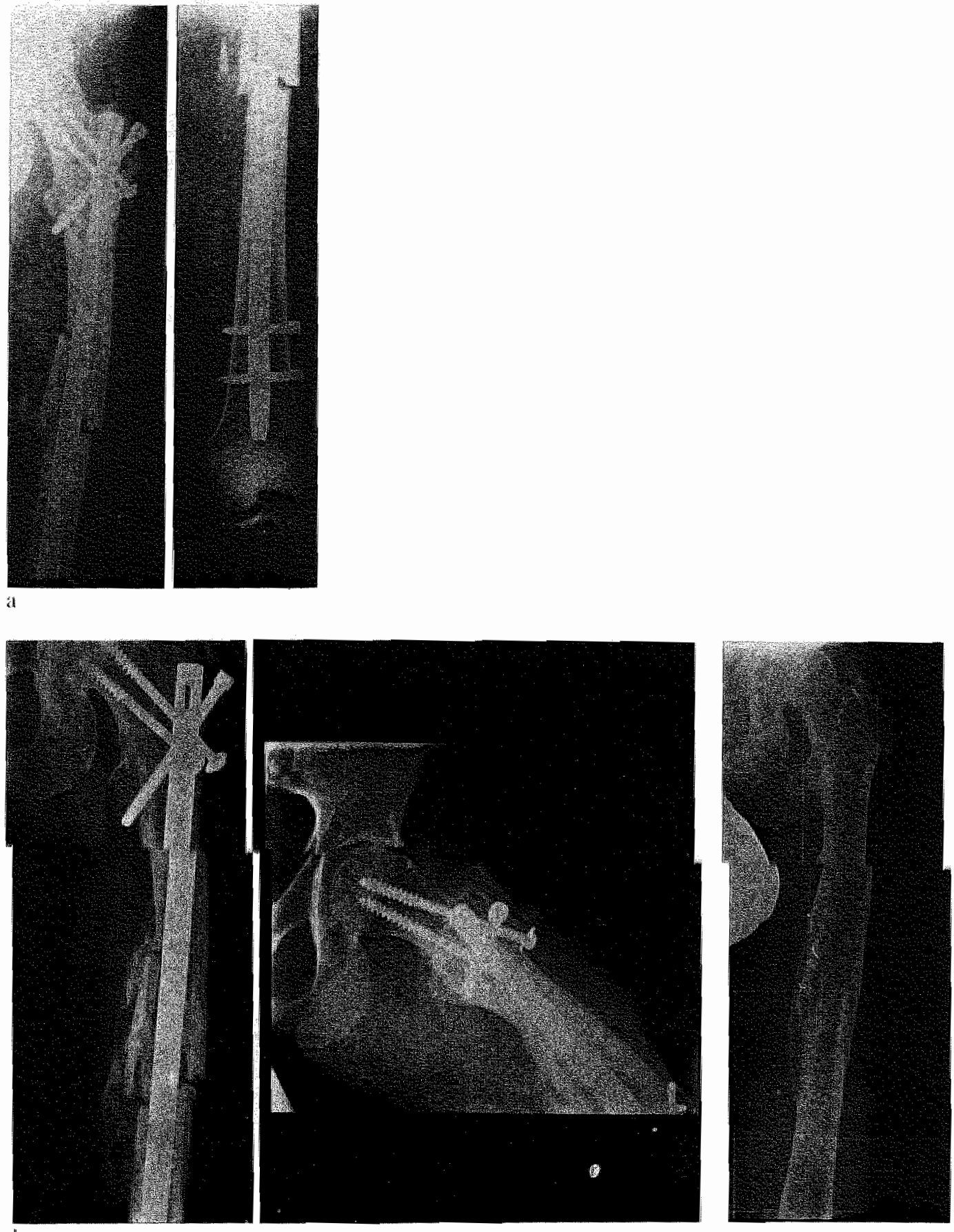

$b$

$c$

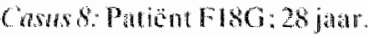

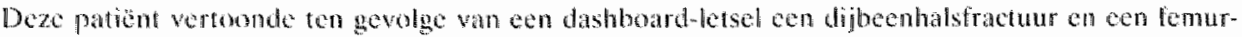

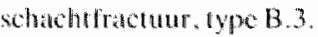

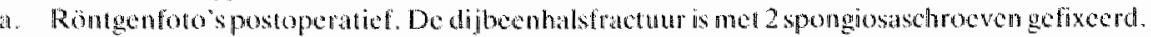

1. Viermanden postoperatiet.

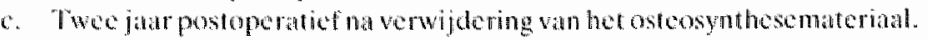



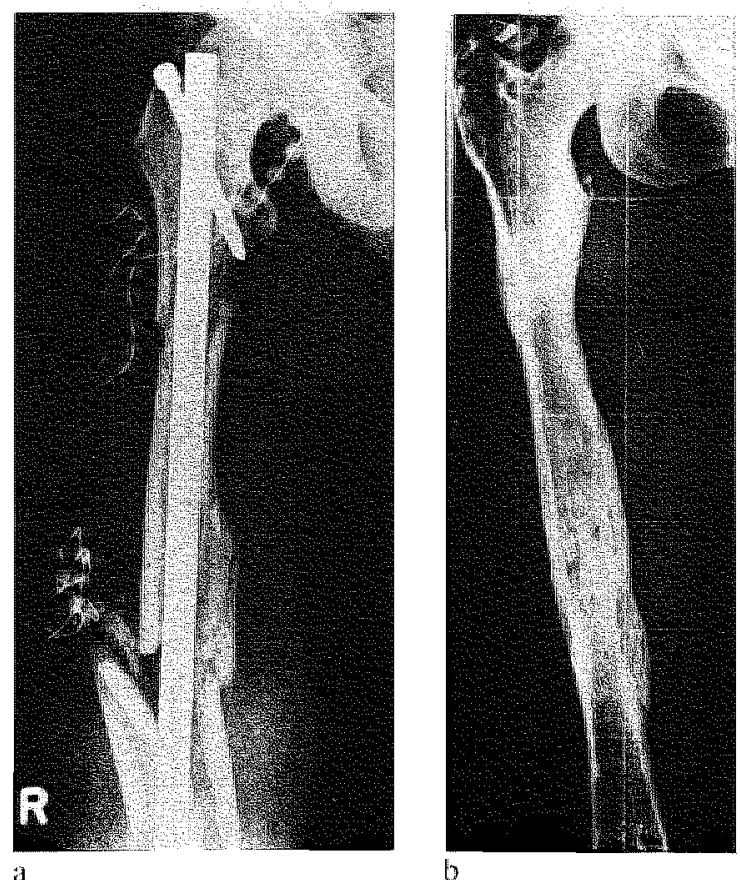

a

b

Casus 9: Patient F22G: 25 jaar.

Eerstegrands open femurfracture techts ten gevolge van ech anto-ongeval, wye C3.2.

a. Röntgentoto direct postoperatief. Een annal Septopal -kettingen zijn ingebrachi ats intectioprophyllaxe.

b. Femur zes jaar na operatic. Twee jaar postoperatief werd de Grendelpen verwijerd. 

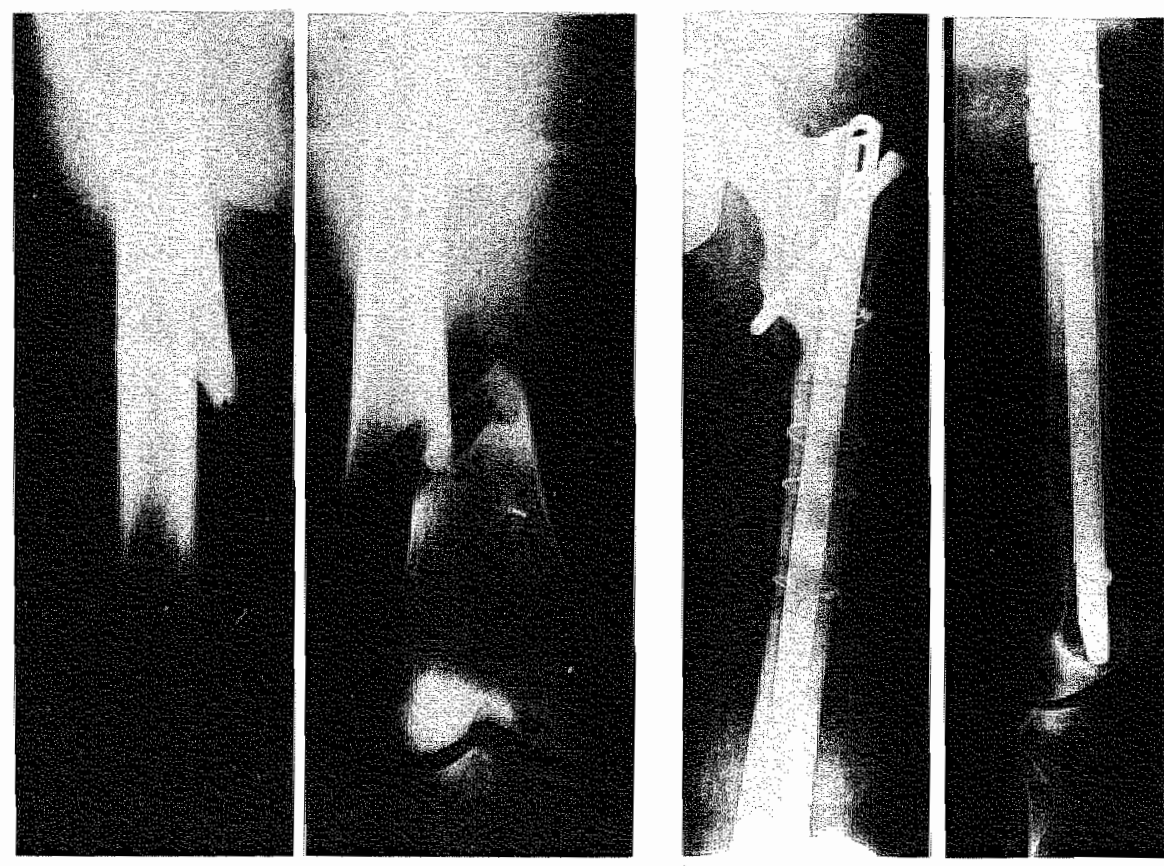

il

()
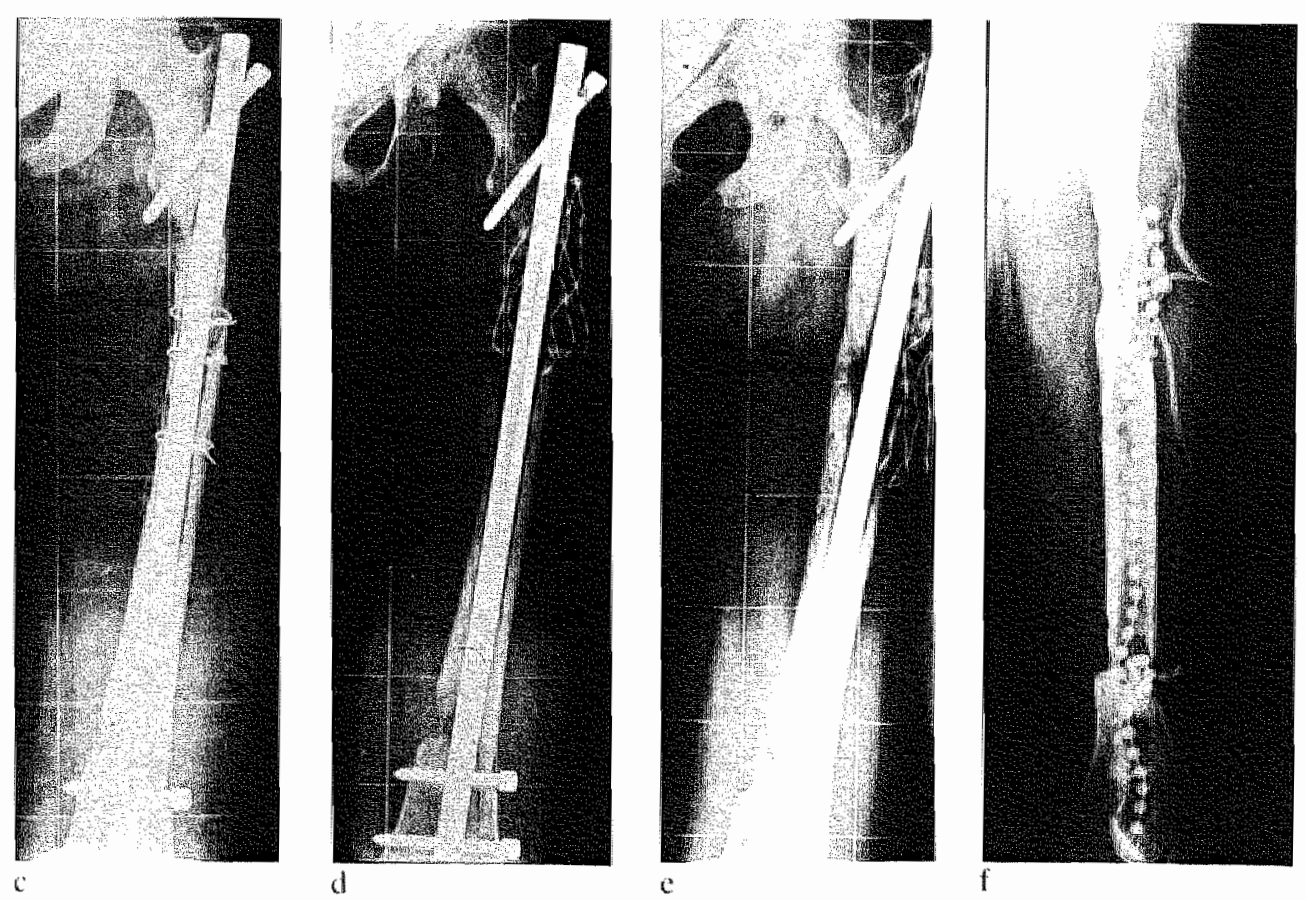


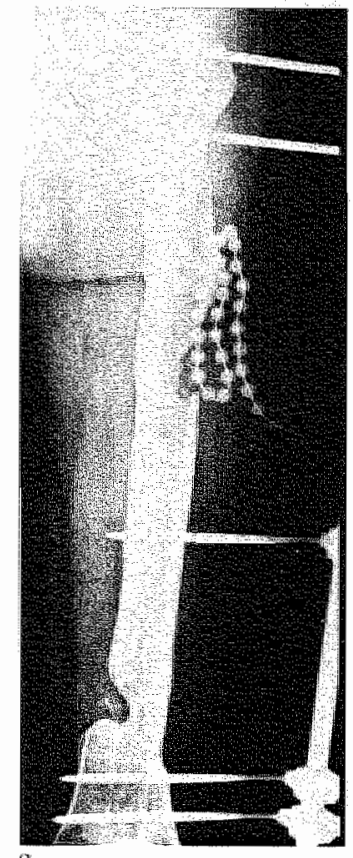

$\mathrm{g}$

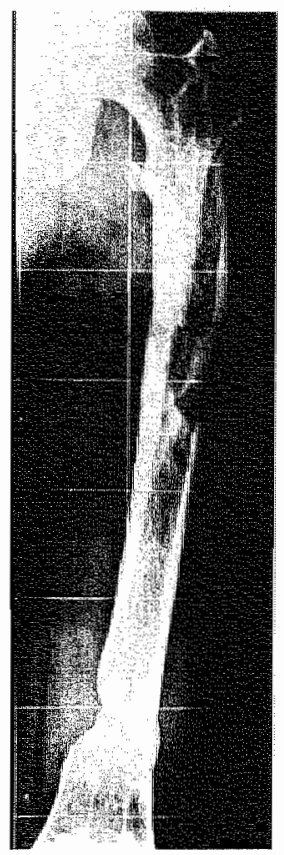

h

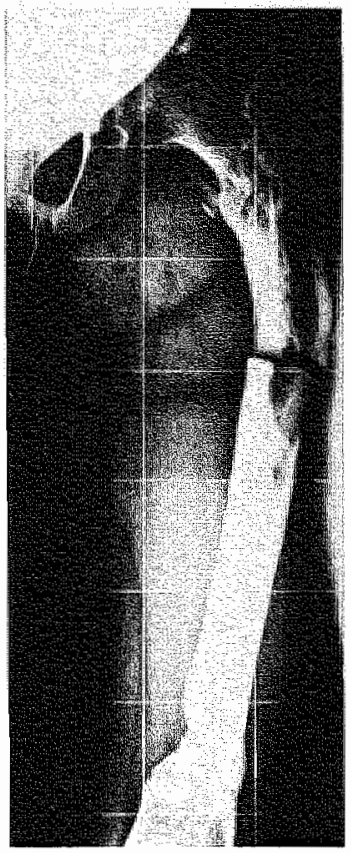

i

Caws 10: Pantiente F23G; 30 jaar.

Eerstegrads open 2-etagefactum, type Cl.1. Patiente werd als voetgangster angereden doon ecen aluto.

a. Röntgenfoto's bijopname.

b. Direct postoperatiof.

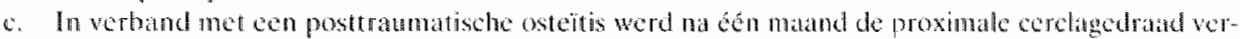
wijderd: fevens vond een sequesterectomie plats.

d. Drie manden postoperatiel werden de resterende ecrelagedraden werwijderd en werd nogmands exn seyuesterectomie verricht. Om de infectio te bestrijden. Werden Septopal"keningengeimplantererd.

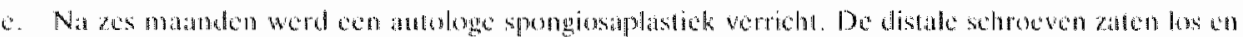
werden verwijderd.

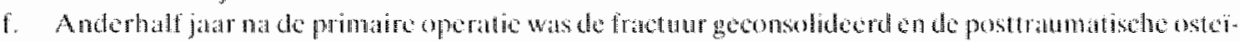
tis onder controle. De pen werd werwijdenal.

g. Uit angst voor en refractur werdecn fixateur externo a angebracht.

h. Vier matanden bater was er voldoende botgenezing en kon de fixateur exterae verwijderal worden.

i. Desondanks trad vier matuden nat het verwijderen van de fixateur exferne cen rofracturir op tongevalge van een gering tratuma. 


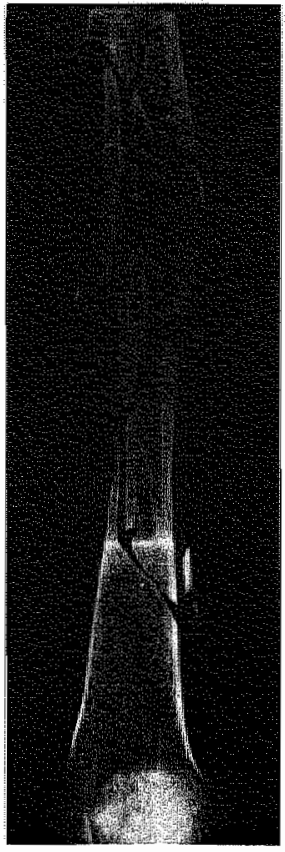

a

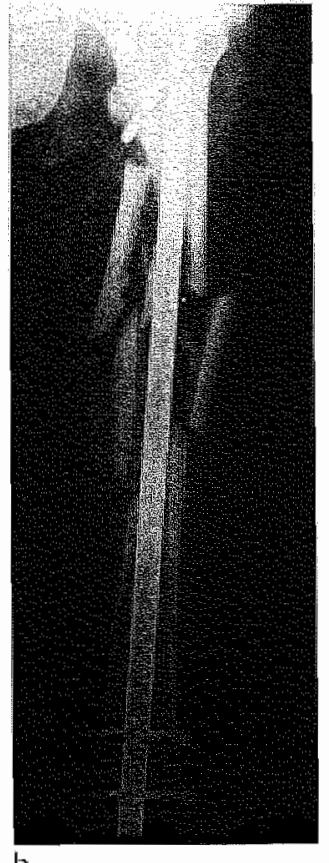

b

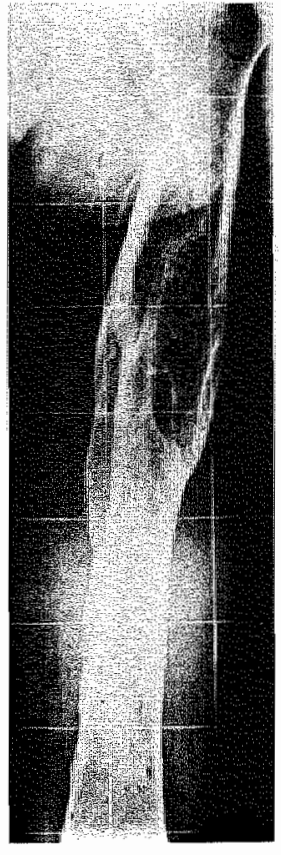

$c$

Censult: Puticnt F27G; 52 jaktr.

Gosloten fonumfraetuur links, type C3.2., ontstan ten gevolge van cen at to-ongeval.

4. Röntgentolo bijopname.

b. Direct postoperatief.

c. Drie fatar na hett ongeval. 


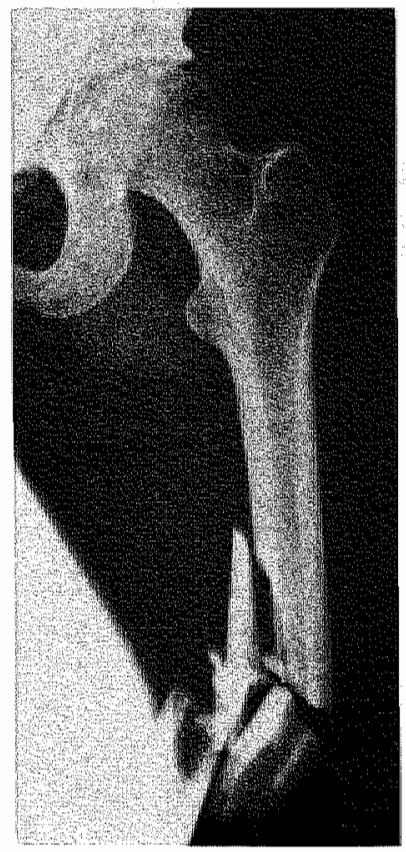

a

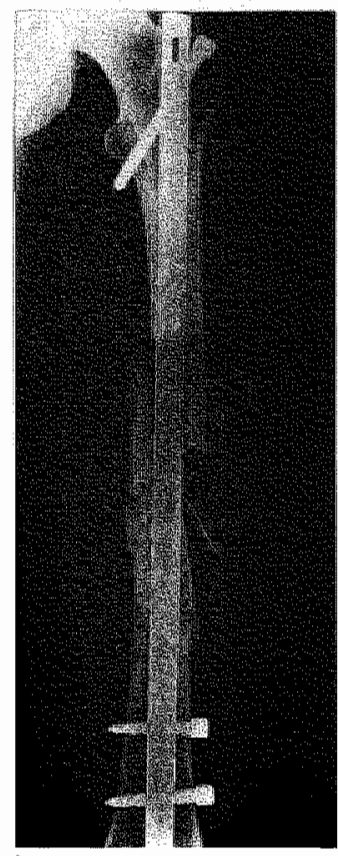

b

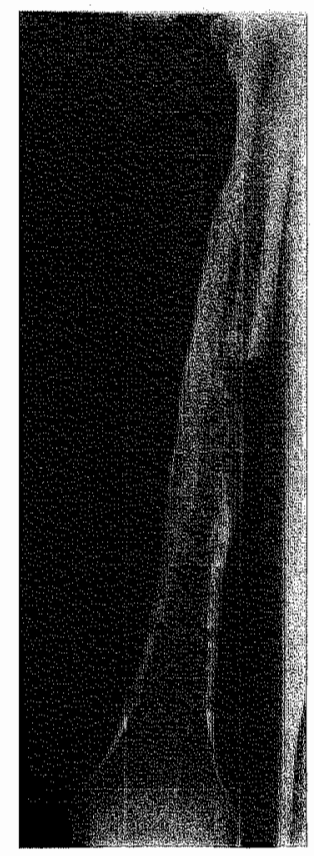

c

Cusus 2: Patiënte F28G; 21 jaar.

Tweedegraads open fenurfactur links, type C2.1. Deze patiënte werd, terwijl zij haar auto besturde. van links door een tram aangereden.

a. Röntgenfoto bijopname.

b. Direct postoperatief. Er werd een debridement van de wond verricht, watrna deze over een Septopal'-ketting primair we rd gesloten.

c. Röntgenfoto 2 jaar na operatie. 

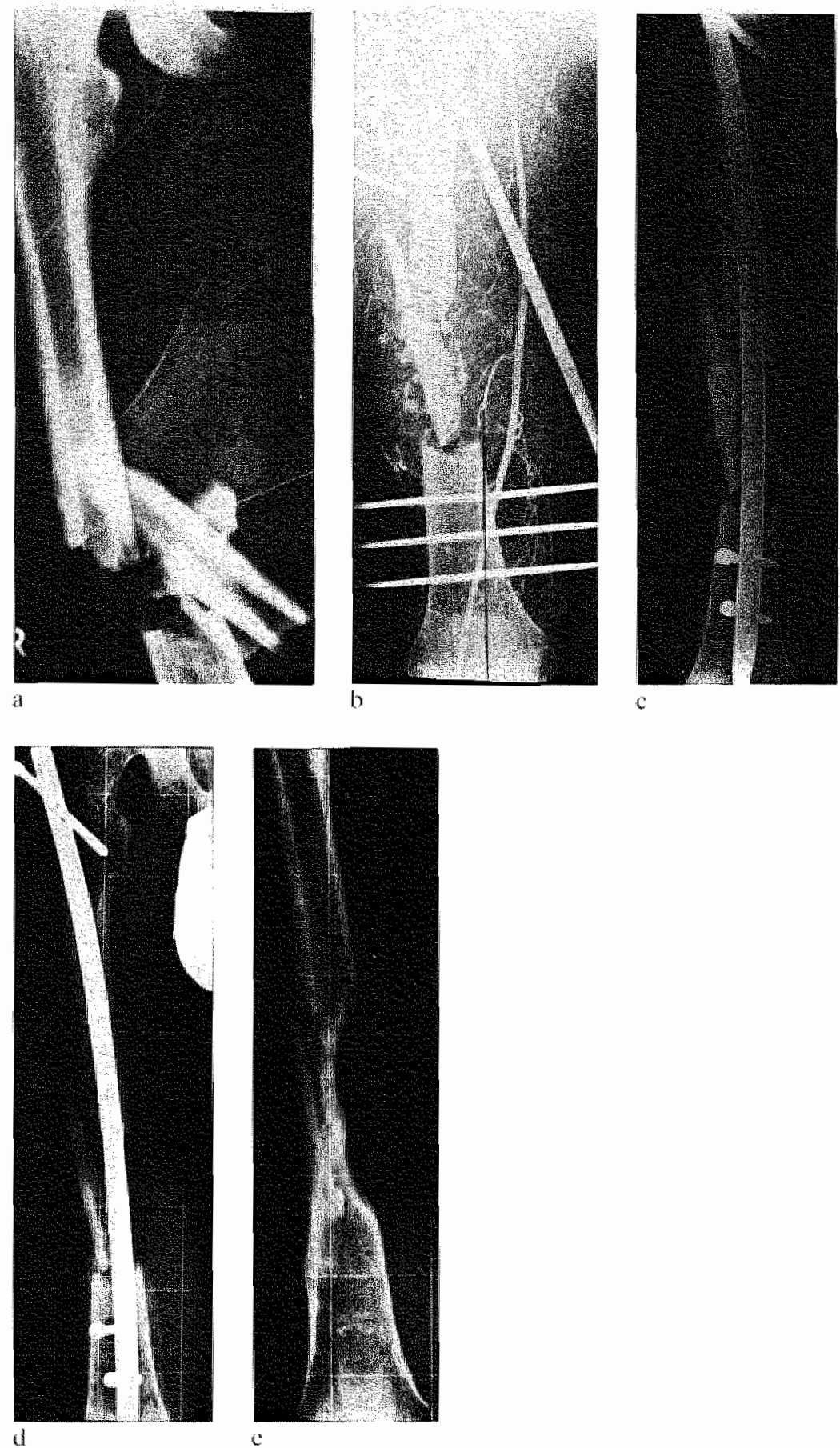
Casus 13: Patient F29G: 17 jaar.

Derdegraads open femurfactuur rechts, rype B.3. ten gevolge van een motorongeval.

a. Röntgenfoto bij opname.

b. Arteriografie twee dagen postoperatief in verband met ischamie van let rechter onderbeen. De fomurf ractutr is gestabiliseerd met een fixateur externe.

c. Na eén maand werd de fixateur externe vervangen door cen Grendelpen, waama zich een post taamatische osteitis ontwikkelde.

d. Vijf maanden na de re-osteosynthese: er is weing of geen callusvorming en de distale schroeven zijn ten gevolge van de infectic losgeraakt.

e. Vijf jaar na het ongeval. Patient loopt met een prothese in verlxand met zijn onderbecnsamputatio en belast het rechter femur volledig. 


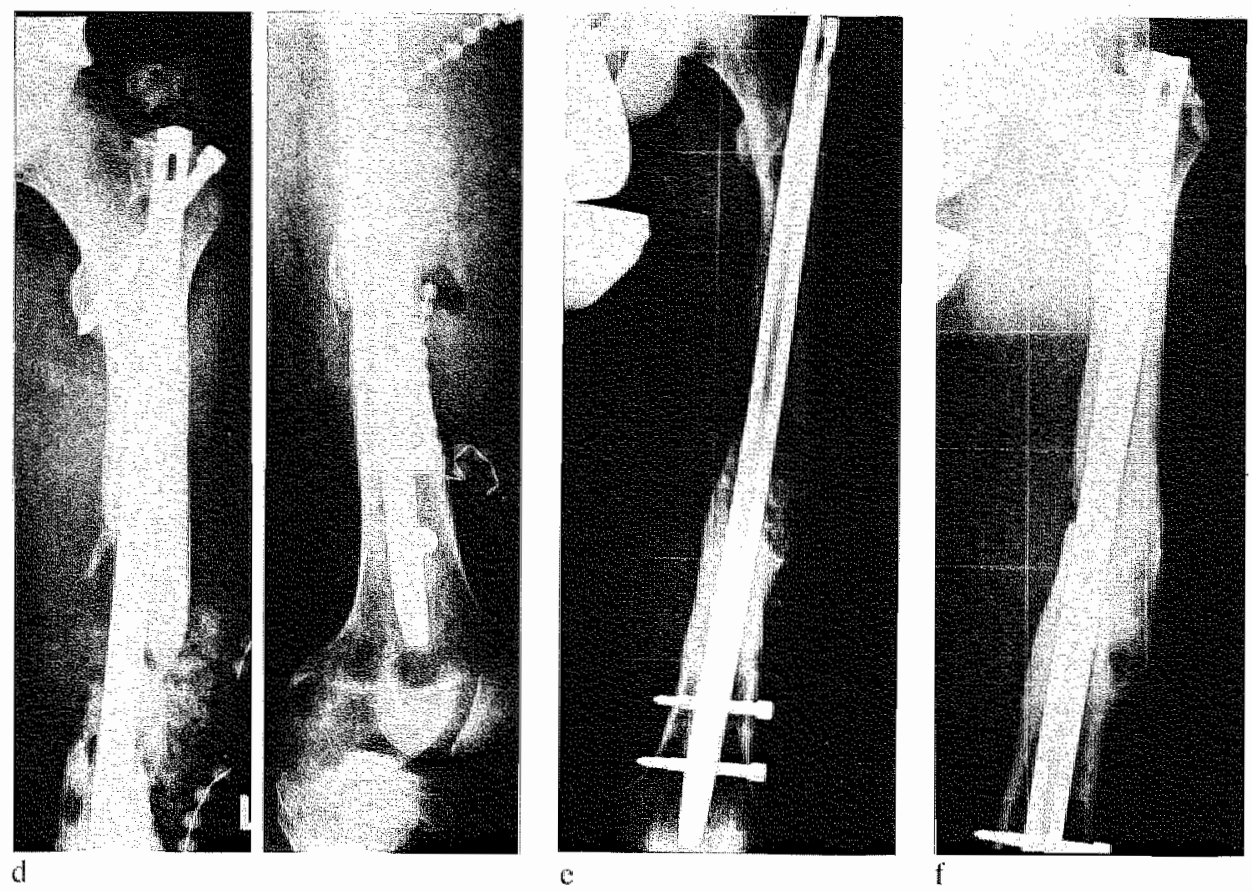

Casus /4: Patient F350:18 jaar.

Twee degraads open femurtiactuu links, type B.3., ontstaan ten gevolge van cen frontale aubobotsing.

a. Röntgenfoto's bijopname.

b. Direct postoperatief. Een driatal avitale fragmenten werden door dic operateur verwijderd.

Septopal'-kralen werden als infectieprophylaxe ingebracht. Desondanks trad een postraumatiselue osteït is op.

c. Na 20 matnden was er econ psendarthrose met penbrenk nanwezig.

d. Er werd een re-osteosynthese verricht met een Grendelpen. Tevens werd cen atologe spongiositplastiek verricht.

c. Vier mataden na de re-ostengythese was er en beginnende consolidatio zodiu do proximalle schrof verwijerd kon worden.

f. Twee jatar na de reostcosynthese de psendarthrose is vollediggeconsolixdeced. 


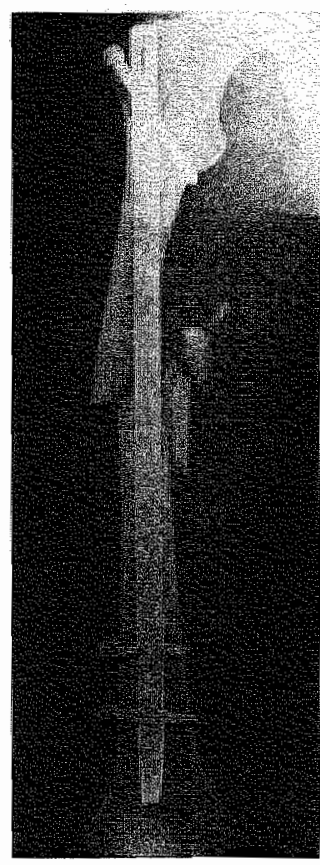

it

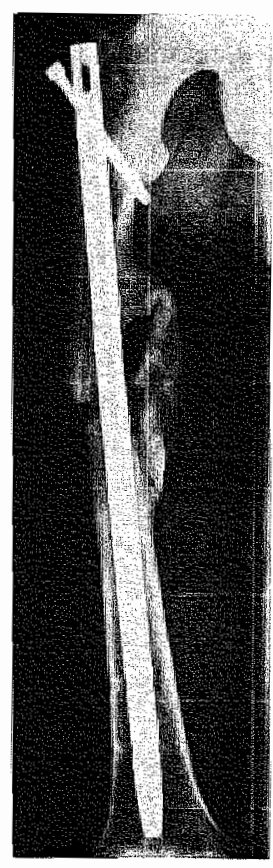

c
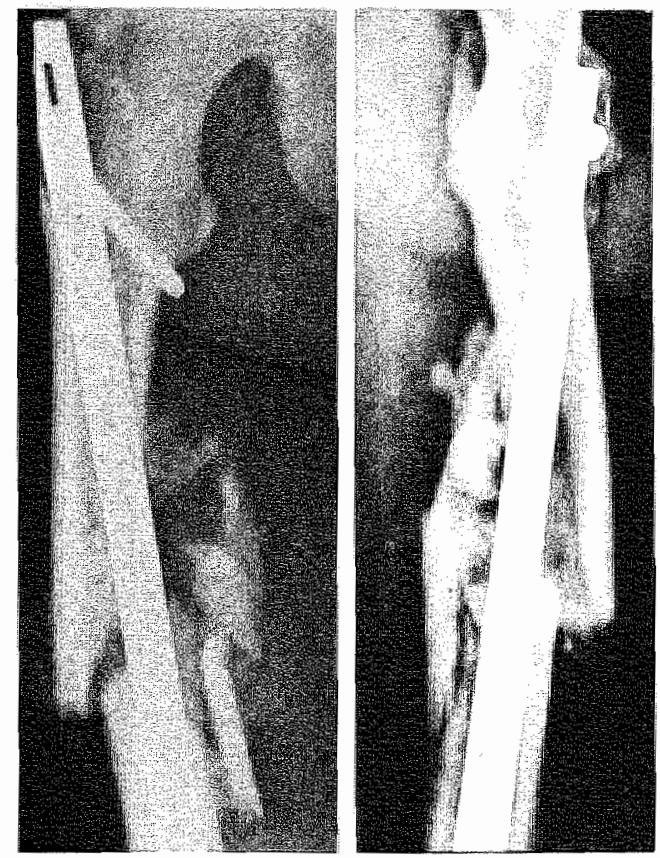

b
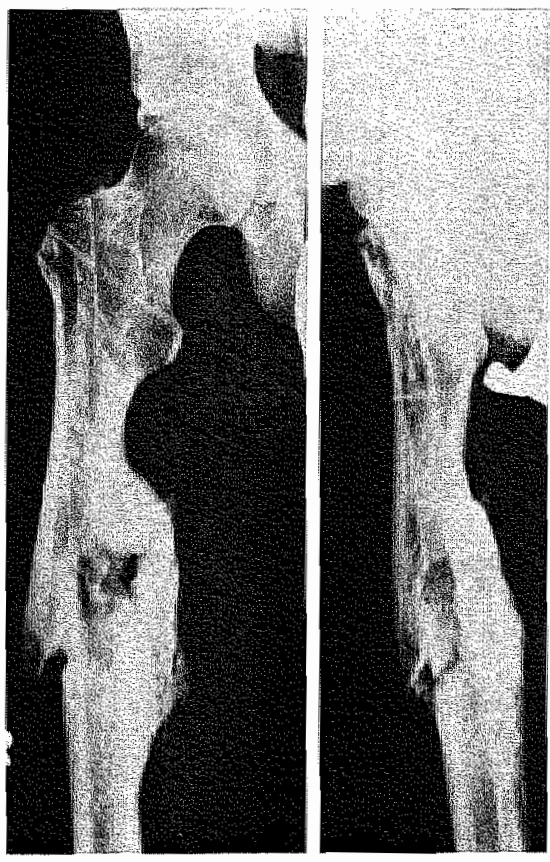

d

Cans 15 : Pationt F $370 ; 21$ jater.

Gexhoten femurbatun rechts, type C.3, ontstan ten gevolge van een motorongeval.

it. Rinntgontoto s dircot postoperatiet.

b. Een matma na operatic: duidelijk is de antecurvatie-en varusafwijking vande fractur zichtbar.

6. Drie mataden postoperatiet; $\mathrm{r}$ is cen beginnende botgenezing.

d. Twe juar postoperatief na werwijdering wan Ge Grendalpen. 


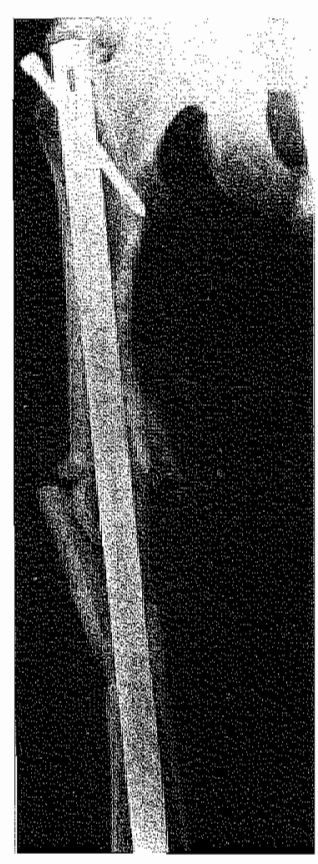

al
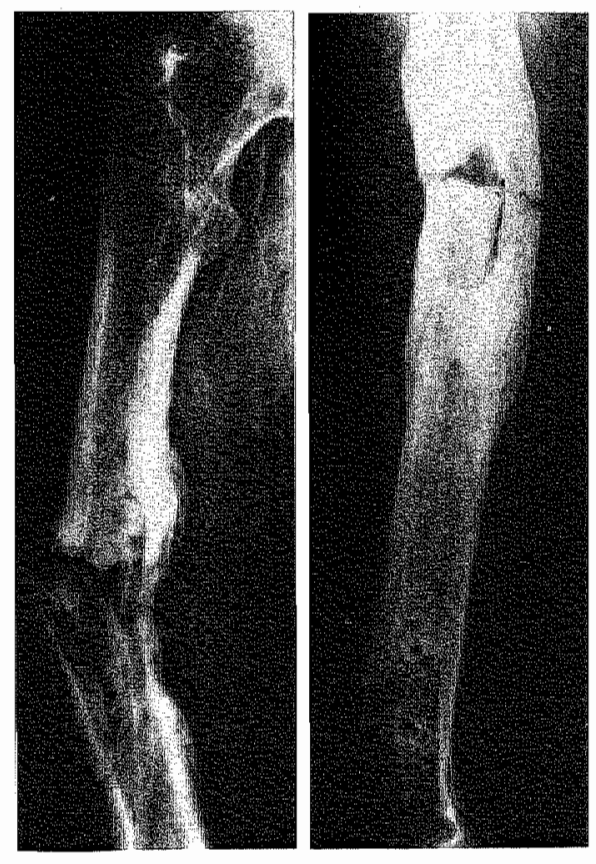

c

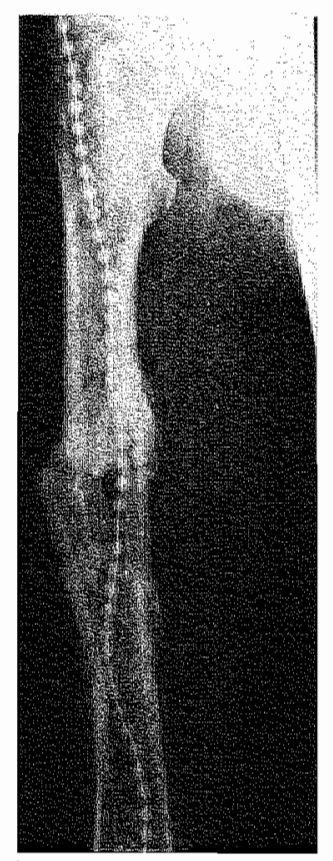

b

Caws /6: Patient F38G; 27 jaar.

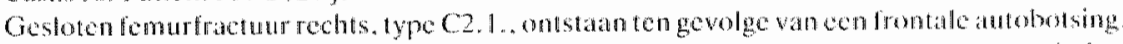

a. Röntgenopname én matand na operatic. Postoperatic ontstond cen posturatumatische ostëlis die onder fistelvorming tot rust kwam.

b. Na vijf maanden werd de Grendelpen verwijderd.

c. Drie matanden later trad en refractun op. Met vier mataden immobilisatie in een gipstyrock consolideerde de refractur voorspoedig.

d. Röngenfoto dric gatar na het ongeval. 

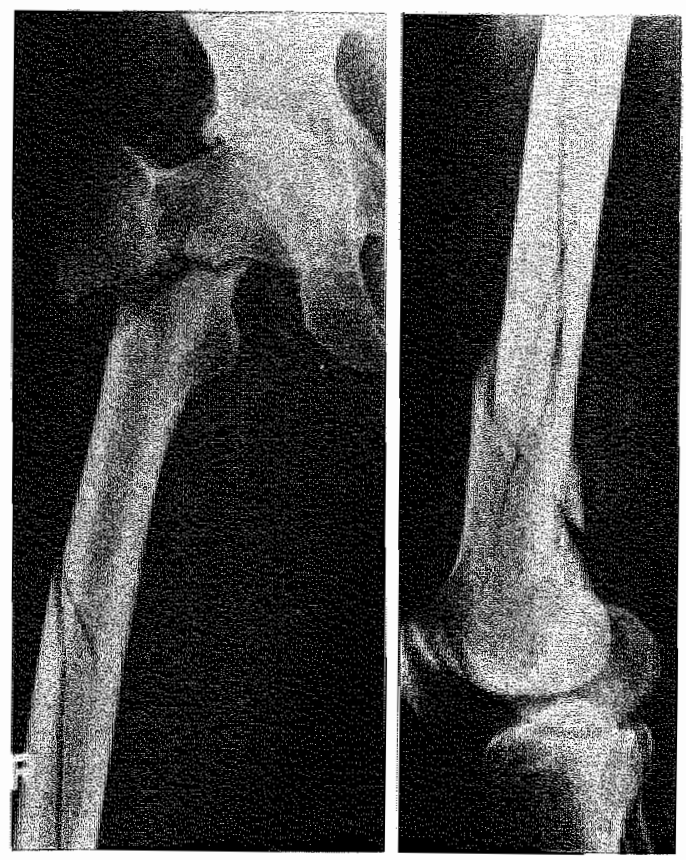

a
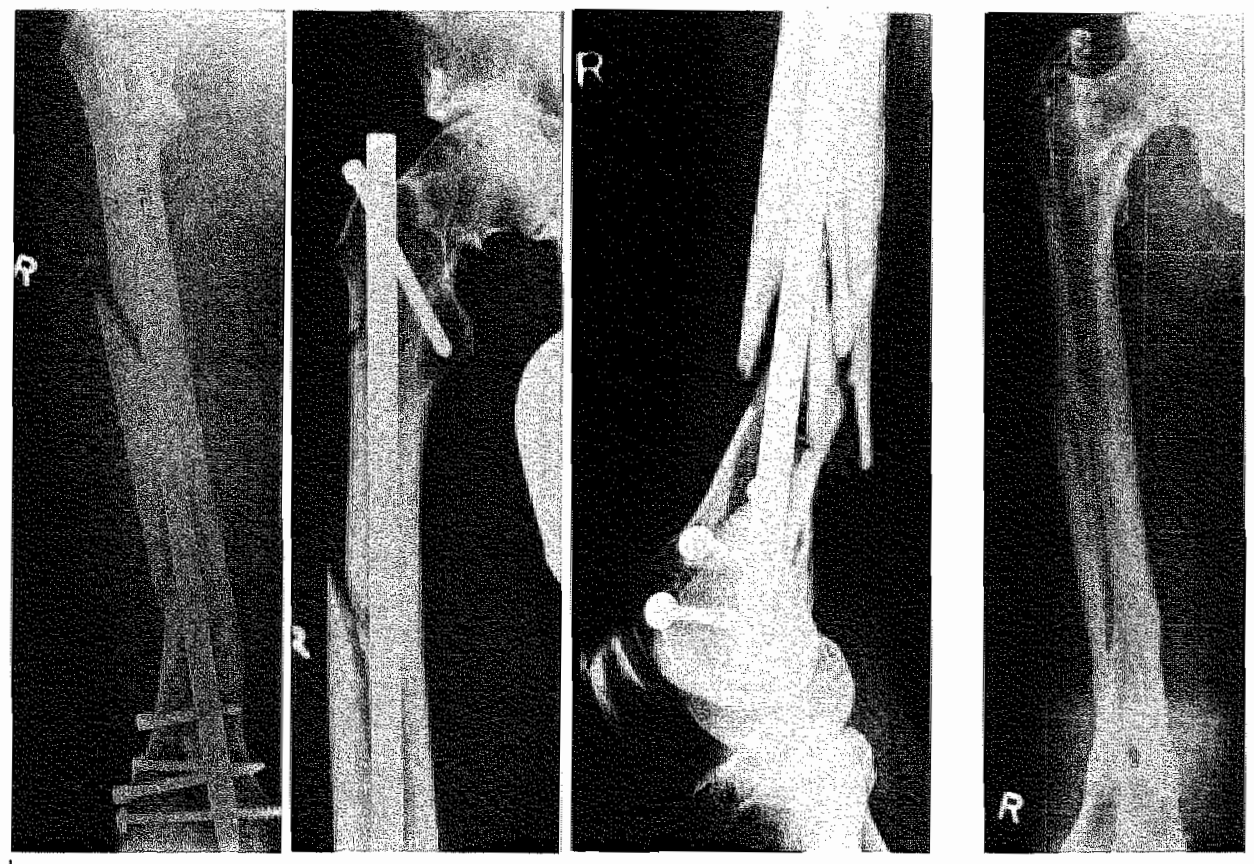

b

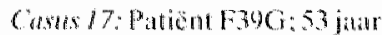

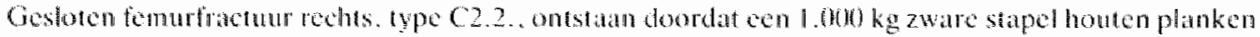
ophet been vanpatient viel.

a. Röntgenfoto's bij opnamu. Hierop zien we cen zogenalamde "reversed" pentrochantere fractuur in combinatio met en comm inutieve femurselhach fractutu die zich uit breidi tot supracondlylair.

b. Röntgentotos ben dag na operatic: tijetens het inslatu van de Grendelpen splect de supracondylaire tracturur tot in het condylmassief. Met 2 sponghosaschroeven kon de fractuur van her condylmassief wardengefixerert.

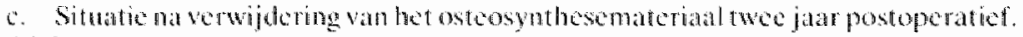




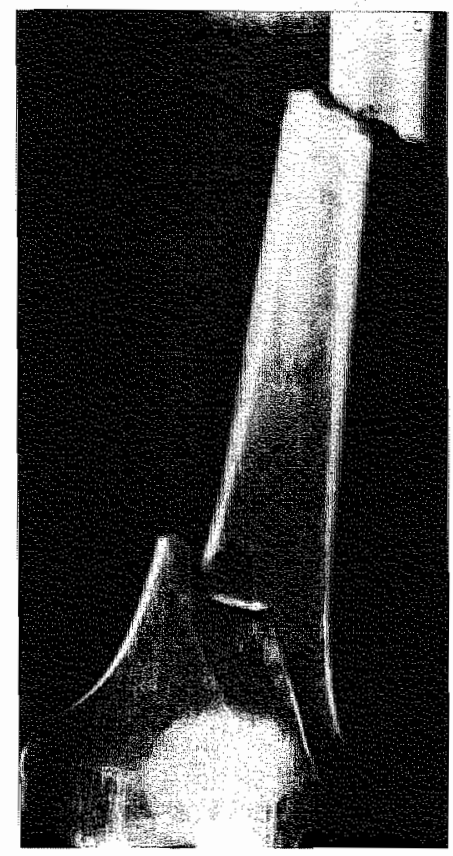

a
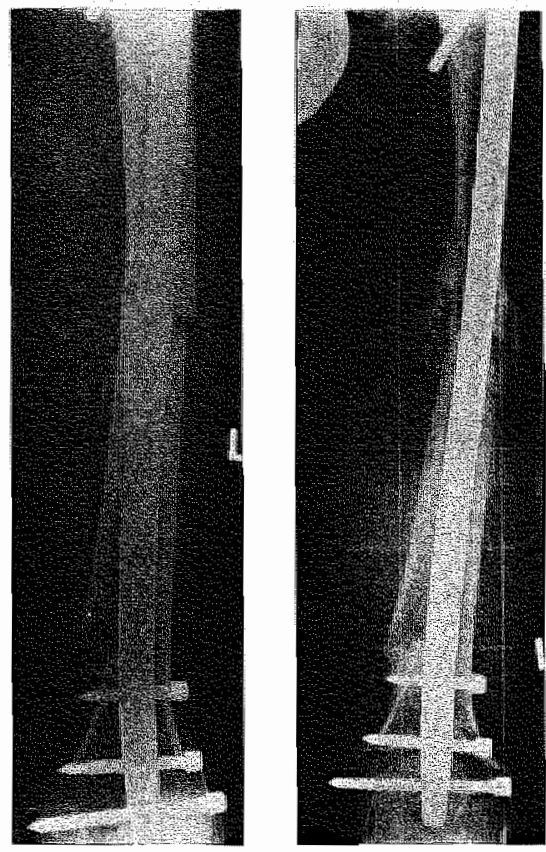

b.

C

Coster 18 : Patent F41G;39 jad

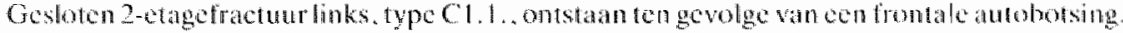

a. Röngentolobijopnane.

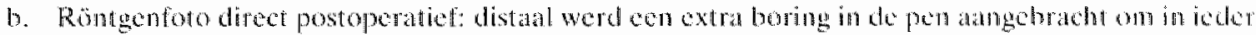
geval twee schroeven onder do meest distale tractur te kumnen inbengen.

c. Vifimataden postoperatief: beide fracturen zing geconsolideced. 

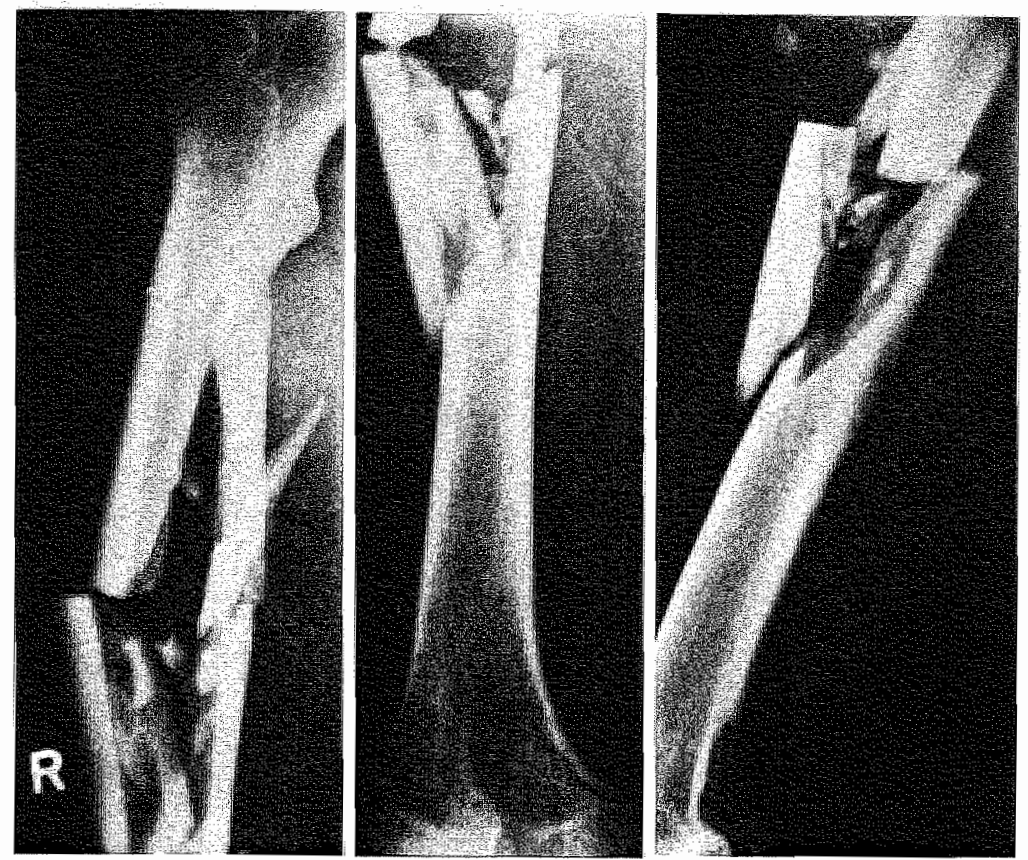

ail
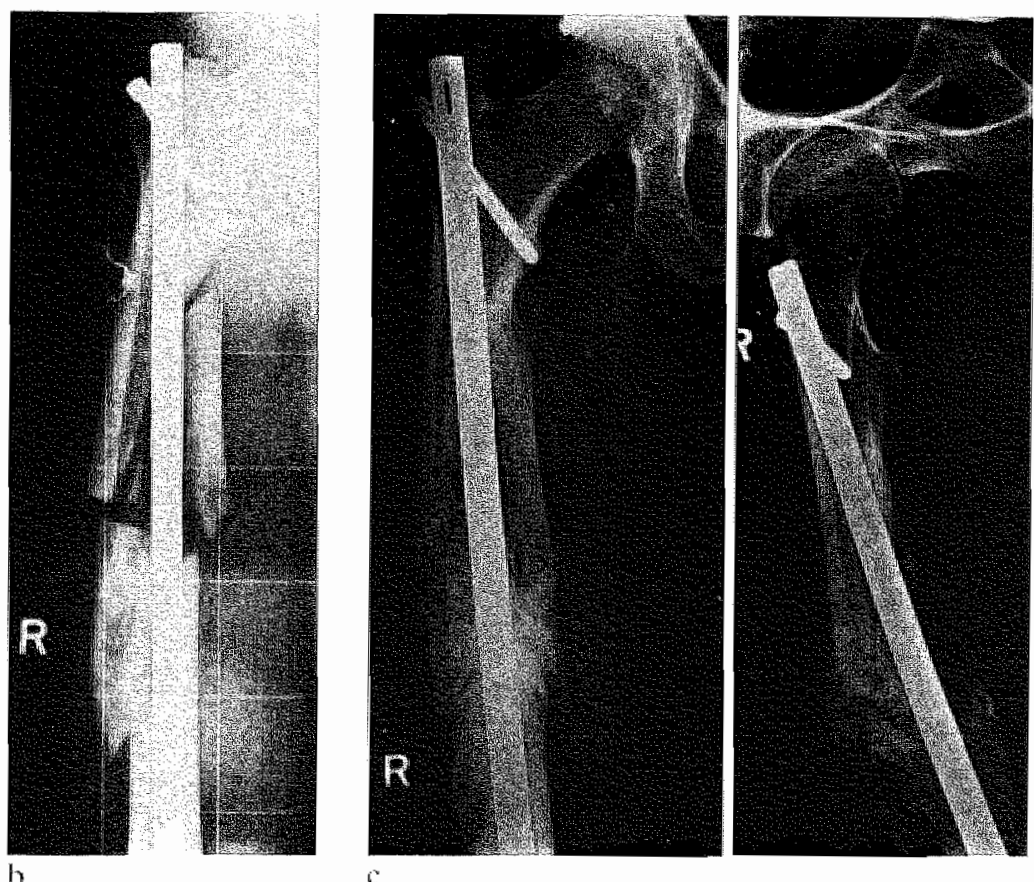

ly

i.

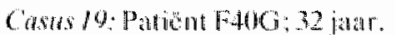

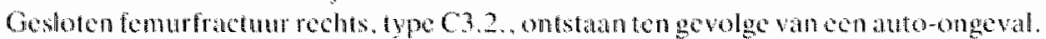

a. Röngentolos bijopname.

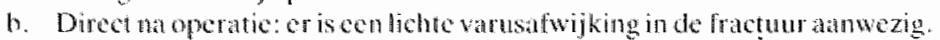

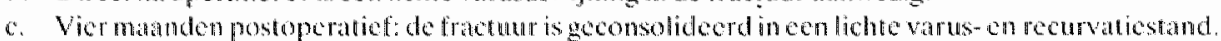




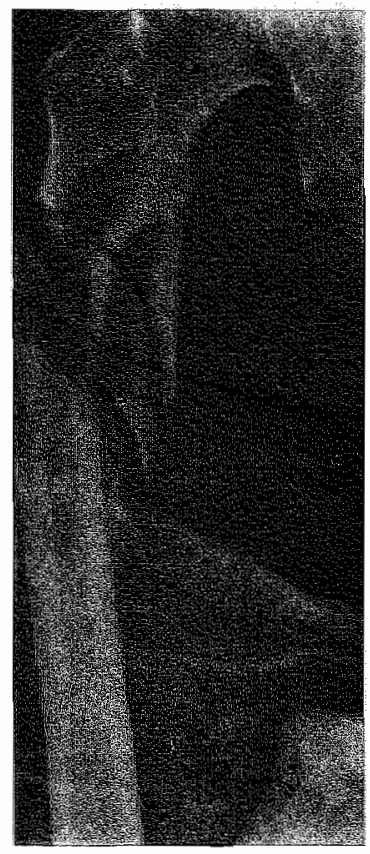

a

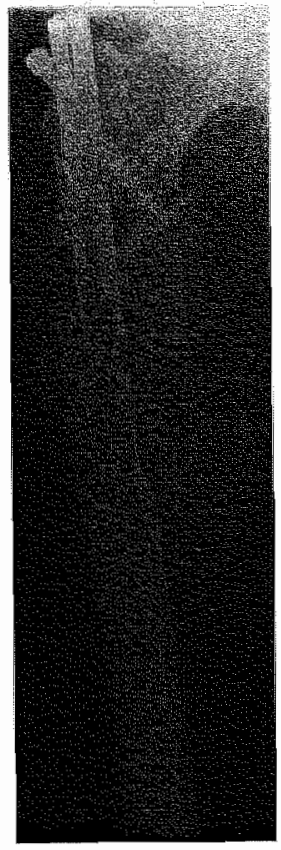

b
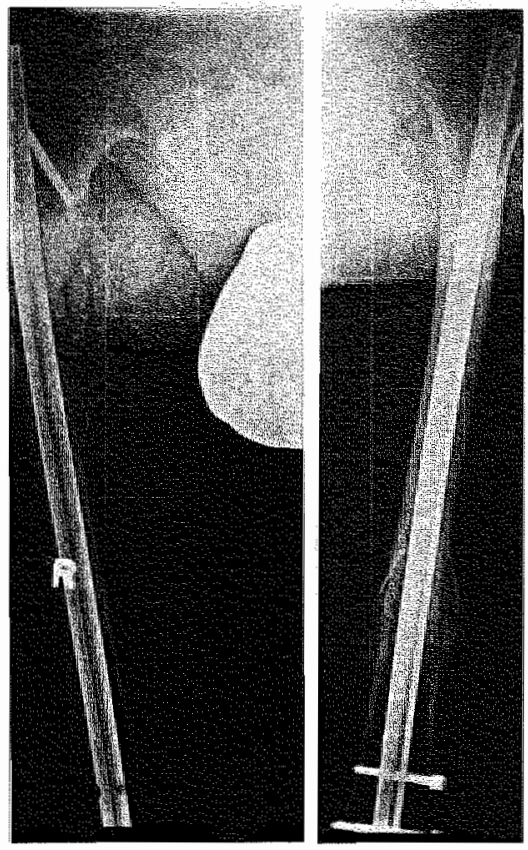

Cuscts $20:$ Patient $\mathbb{F} 42 \mathrm{G} ; 27$ jatar.

Gesloten femurfractur rechts, type B.3., ontstan ten gevolge van een auto-ongeval.

a. Röntgentorobijopname.

b. Drie weken postoperatiof.

c. Vier madnden postoperatief: de consolidatie is wrijwel compleet, cen lichte varnsafwijking van de dijbeenthals in vergelijking met links is zich baar. 


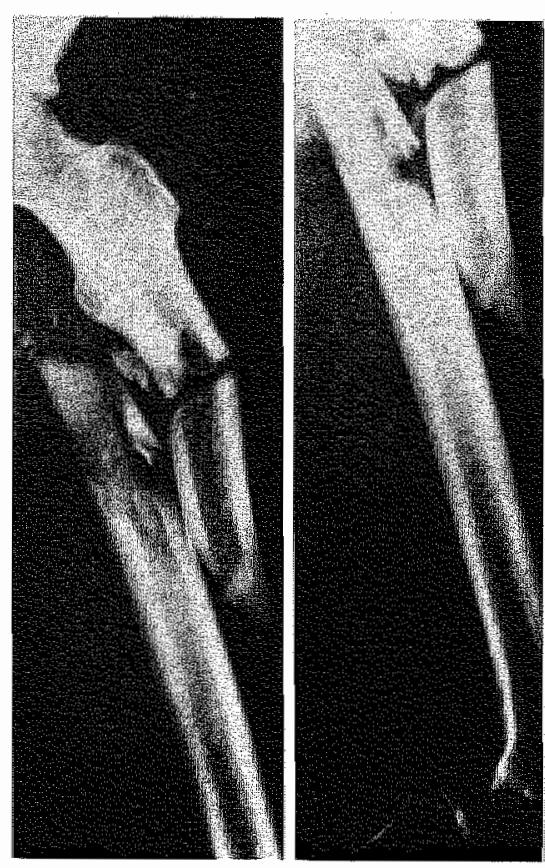

d.

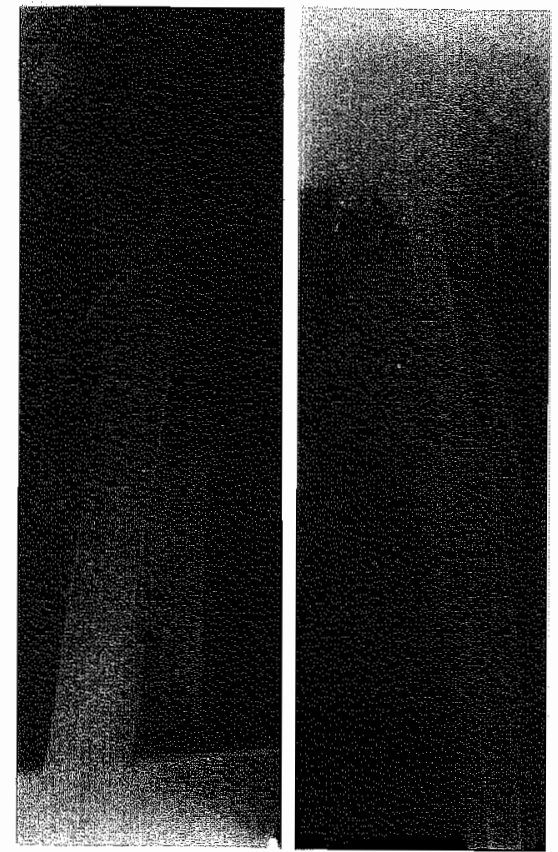

b

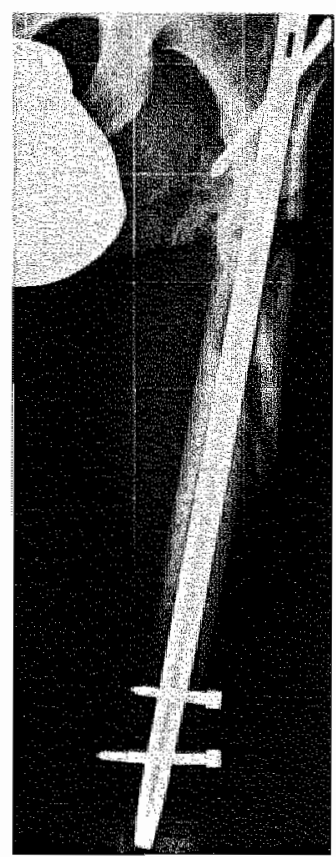

c

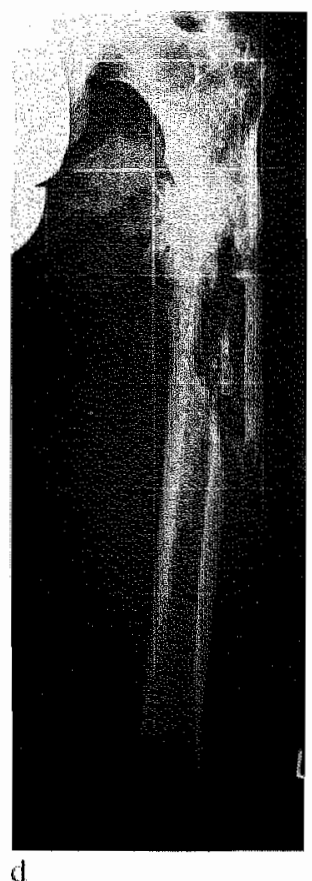

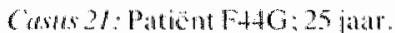

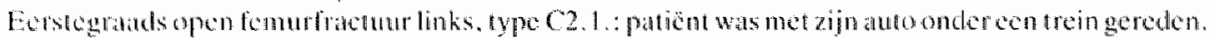

a. Renticonfolo"s bijoprame.

b. Dircet postoperatiot.

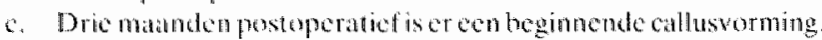

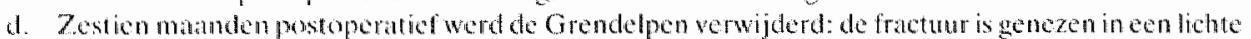
varusciand. 


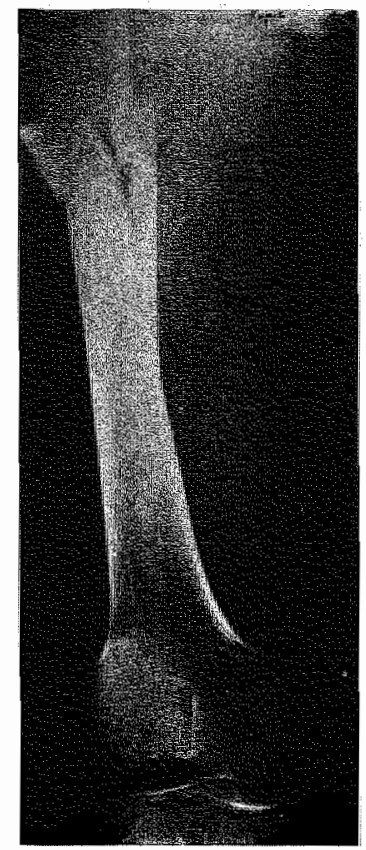

at

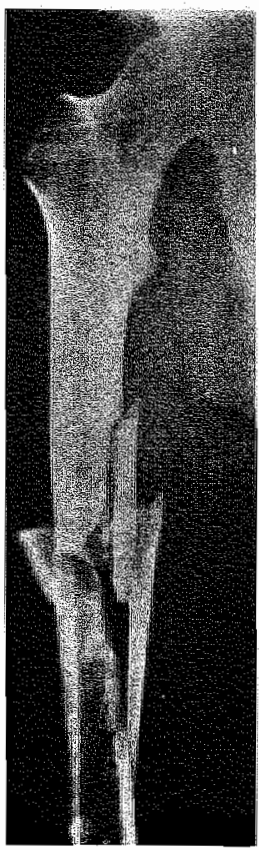

Coswas 22: Patient F47G; 35 jadt.

Gesloten femurfractur rechts. type C2.1. Patient werdonderedn stapel stenen bedolven.

a. Röntgentoto's bijopname.

b. Eén ruand postoperatief.

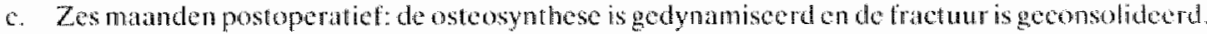




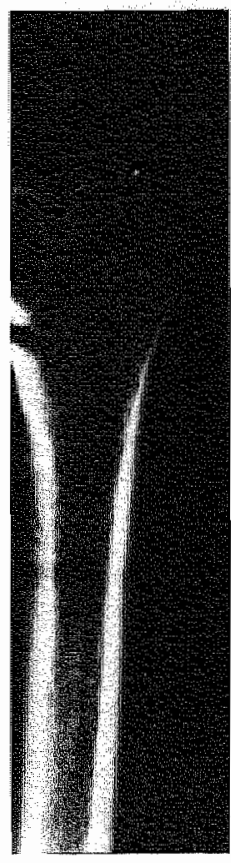

a

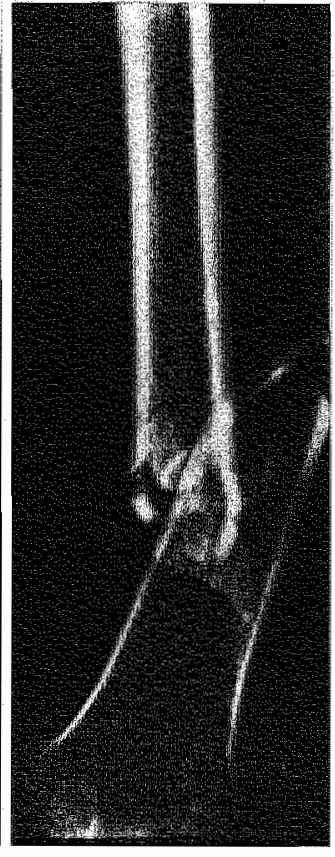

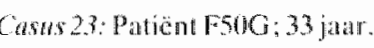

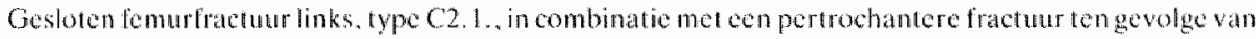
econatorongewal.

a. Röntgenfoto"s bijopmanu:

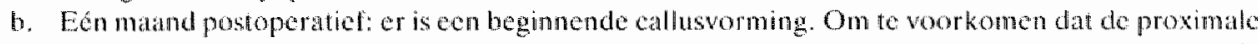
schroel uh de dijbeenhals liep. moest de Grendelpen bij de operatle 2 cm onder het riveau van de trochanter matjor verzonken wordery.

c. Vietenhalve mand postoperatief: beide fracturen zijn geconsol idecerd. 


\section{RESULTATEN VAN DENIET-GRENDELPEN- \\ GROEP IN VERGELIJKING MET DE \\ GRENDELPENOSTEOSYNTHESEN}

Uit de gegevens van hoofdstuk 8 blijkt dat de patiëntengroepen wit Frankfort en Heerlen goed vergelijkbaar zijn. In dit hoofdstuk worden de resultaten beschreven van de patıenten uit Heerlen bij wie de femurfracturen met diverse technieken werden behandeld.

\subsection{Behandelingstechnieken}

De behandelingstechnieken, die in het De Weverziekenhuis werden toegepast, zijn weergegeven in tabel $22(n=38$ fracturen $)$.

Tabel22 Mectrigment-enetagefracturen De Weverzickenhuis

$(n=38$ tratctures $)$

Plantosteosynthesion
Consertatiof (tractie)
Kantscherpen (net cerclages)
Enderpennen

17

4

$16(10)$

I

\subsection{Osteosynthesetechnieken in relatie tot de fractuurvormen}

In tabel 23 is de relatie tussen de fracturvorm en de osleosynthesctechnick aragegeven.

Tebo 33 For

\begin{tabular}{|c|c|c|c|c|c|c|}
\hline $\begin{array}{c}\text { Practume } \\
\text { vorm }\end{array}$ & (totan) & $\begin{array}{c}\text { Platostoo- } \\
\text { synthese }\end{array}$ & $\begin{array}{c}\text { Künischer- } \\
\text { pen }\end{array}$ & $\begin{array}{l}\text { (mel } \\
\text { cerclages) }\end{array}$ & $\begin{array}{c}\text { Conscit- } \\
\text { vatiol }\end{array}$ & 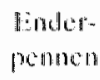 \\
\hline B.3. & $(n=14)$ & 5 & 9 & $(5)$ & fi & 0 \\
\hline$C .1$ & $(n=3)$ & 1 & 2 & $(1)$ & (1) & (i) \\
\hline$C .2$ & $(n=12)$ & 6 & 4 & (4) & 1 & 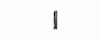 \\
\hline C.3. & $(n=9)$ & 5 & 1 & (ii) & 3 & 0 \\
\hline
\end{tabular}

Het blijkt dat narmate de verbrijzeling untgebreider was (fracturvonnen C.2. en C.3.) de plaatosteosynthesen meer gebruikt werden. Het is technisch immers onmogelijk fracturen van het type C. 3. met een Küntscherpen te behandelen. In de groep van 17 plaatosteosynthesen kon 12 mal volstad worden met een platosteosynthese allén. 2 Maal warer cerclagedraden noodzakelijk om de osteosynthesc voldoende stevigheid te geven en 3 mal werd gebruik gemakt van 2 platen vanwege de lengte van het lractururgebied. 
Opvallend is dat ar geen primaire spongiosaplastieken werden verricht, hetgeen de ladste jaren bij iedere femurfractuur, die met een plaat wordt gestabiliseerd, als obligat beschouwd wordt (Müller 1977). Bij 10 van de 16 Küntscherpenosteosynthesen werden cerclagedraden gebruikt om de stabiliteit van de osteosynthese te vergroten.

\subsection{Operatietechnische problemen}

Omdat platen, Küntscherpennen en Enderpennen uir biomechanisch oogpunt minder gexchikt zijn om meerfragment-en elagelracturen te stabiliseren, ligt het voor de hand dat het anatal technische problemen hoog was (tabel 24).

Fob 24 Operabetechnische problenen $(\mathrm{n}=34$ (racturen)

\begin{tabular}{|c|c|c|c|}
\hline & $\begin{array}{l}\text { Pidatoseosynthesen } \\
\qquad(n=17)\end{array}$ & $\begin{array}{c}\text { Kupernous } \\
(n=16)\end{array}$ & $\begin{array}{l}\text { Enderpenoen } \\
\qquad(n=1)\end{array}$ \\
\hline 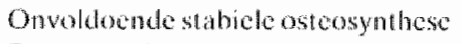 & 2 & 3 & 1 \\
\hline Diaslase in het fracturgebied & 3 & - & - \\
\hline
\end{tabular}

De technische problemen waren in deze groep in vergelijking met de Grendelpenosteosynthesen van geheel andere ard. Bij de Küntscherpenosteosynthesen die in Heerlen principieel via de open operatietechniek werden verricht, waren er geen problemen wat betreft het inbrengen van het osteosynthesemateriaal. De technische problemen zowel bij de plaatu-als bij de Küntscherpenosteosymthesen waren vooral te wijten aan de beperkingen van het beschikbare osteosynthesemateriaal om bij dit soort fracturen een voldoende stabiele osteosynthese te bereiken.

Bij de Grendelpenosteosynthesen werden de technische problemen veroorzaakt door het feit, dat de verschillende operatieve fasen grotendeels via de gesloten operatietechniek verricht dienden te worden en door het optreden wan een spildraai in de pen wardoor de distale penopeningen zich niet in het frontale vlak presenteerden.

In de groep Küntscherpenosteosynthesen bleek de osteosynthese 3 maal zó instabiel dat postoperatief tractie noodzakeljik was (patiënt H07K, H08K, HOK). De Enderpenosteosyn these bood eveneens niet de gewenste stabiliteit zodal ook in dit geval postoperalief tractie vereist was. In totad waren er bij 34 osteosynthesen 9 maal $(26,5 \%)$ operatietechnische problemen. Van de 17 intramedullaire osteosynthesen moesten or $4(23,5 \%)$ met tractie nabehandeld worden. In de groep Grendelpenosteosynthesen ( $\mathrm{n}=55$ fracturen) was slechts in één geval (patiënt F45-aG) postoperaticf tractio nodig $(1,8 \%)$.

Bij de 4 conservatief behandelde fracturen waren er ondanks de lange duur van de tractie geen problemen wat betreft het handhaven van de repositie en traden er geen complicaties op ten gevolge van de draadextensie.

\subsection{Belasting van het been postoperatief}

Een vartiële belasting was gemiddeld na 77 dagen mogelijk ( $=12$ fracturen). (Alleen de patiënten zonder begeleidende letsels, zonder prae-existente ziekten en 
zonder locale of algemene complicaties die van invloed zijn op de bellasting van het been werden in deze berekening meegeteld.) Een volledige belasting was bij deze patiënten gemiddeld na 256 dagen mogelijk. In de groep Grendelpenosteosynthesen zonder begeleidende letsels was een partiële belasting gemiddeld na 18 dagen en een volledige belasting na 72 dagen mogelijk. In vergelijking met de andere behandelingstechnieken is dit een verschil van respectievelijk 59 en 184 dagen voor wat betreft partiele en volledige belasting ten gunste van de Grendelpenosteosynthesen.

In tabel 25 is het tijdstip van partiele en volledige belasting voor beide groepen weergegeven wanneer we geen rekening houden met begeleidende letsels en locale of algemene complicaties die invloed hebben op de mobilisatie en de belasting. Ook dan blijkt er een duidelijk verschil wat betreft het tijdstip van partiële en volledige belasting tussen de groep Grendelpenosteosynthesen en de groep overige behandelingstechnieken te bestaan. (In de groep Grendelpenosteosynthesen werden de fracturen van 3 kort na de operatie overleden patienten en van I paraplegische patiënt niet meegerekend.)

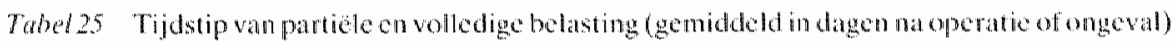

\begin{tabular}{lcc}
\hline inclusief begeleidendeletsels & $\begin{array}{c}\text { Partiölic } \\
\text { belasting }\end{array}$ & $\begin{array}{c}\text { Volledige } \\
\text { belasting }\end{array}$ \\
\hline Grendelpengroep $(n=51$ fricturen $)$ & 44 & 115 \\
Niet-Grendelpengroep $(n=38$ fracturen $)$ & 95 & 308 \\
\hline & Partiele & Volledige \\
exclusief begeleidende letsels & belasting & belasting \\
\hline Grendelpengroep $(n=12$ fracturen $)$ & 18 & 72 \\
Niet-Grendelpengroep $(n=12$ fracturen $)$ & 77 & 256 \\
\hline
\end{tabular}

\subsection{Complicaties}

\subsubsection{Zenuwletsels}

3 Maal $(7,9 \%)(n=38$ fracturen) werd een zenuwletsel geconstateerd. 2 Maal een $\mathrm{N}$. ischiadicusletsel (patiënt H06K, H07K) en één $N$. peroneusuitval (patiënt H10K). Eén N. ischiadicusletsel herstelde niet volledig. Procentueel is er geen wezenlijk verschil tussen de Grendelpengroep met $8 \%$ zenuwletsels en de niet-Grendelpengroep met $7,9 \%$ zenuwletsels.

\subsubsection{Posttraumatische osteïtis}

Bij 6 geopereerde fracturen $(n=34$ fracturen) trad postoperatief een osteit is op $(17,6 \%) .3$ Platosteosynthesen en 3 Küntscherpenosteosynthesen infecteerden (patienten H01P. H08P, H1IP, H05K. H10K. H14K). In vergelijking met hel op zich al hoge percentage van $7,7 \%$ in de Grendelpengroep is $17,6 \%$ hoog te noemen; vooral wanneer we in aanmerking nemen, dat er in de Grendelpengroep $29,1 \%$ open fracturen waren tegen slechts $13,2 \%$ in de niet-Grendelpengroep. Bij de 4 
fracturen die conservatief behandeld werden, trad geen post traumatische osteitis op. Wanneer we de 4 conservatief behandelde fracturen meerekenen in de nietGrendelpengroep dan is het percentage fracturen, waabij een postraumatische osteitis optrad, in deze groep $15.8 \%(n=38$ fracturen $)$.

\subsubsection{Aanvullende (operatieve) maatregelen tot consolidatie van de fracturen}

In totaal waren 8 re-osteosynthesen noodzakelijk bij 5 patiënten. Bij 2 patiënten werd geen re-osteosynthese verricht, maar werd wan operatieve naar conservatieve behandeling overgeschakeld. Eénmaal was een spongiosaplastiek voldoende om de fractuur tot genezing te brengen. Bij 8 van de 34 operatief behandelde fracturen $(23,5 \%)$ was de primaire operatie niet voldoende on de fractuur tot genezing te brengen (tabe 26$)$. Tn de Grendelpengroep was dit percentage $11.5 \%$.

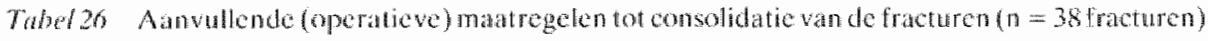

1. Pathent Hosp: intertio

2. Putrom Howp: psedianthase

3. Pation HIIP: intocio

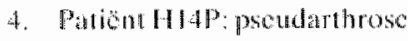
+ platoreuk

5. Patient H1.5P: vertragde consolidatic

6. Pintiont Hok: infectic

7. Parient H1/K:K-penverbogen.

8. Paron HIK: inferte $\rightarrow$ plate $\uparrow \rightarrow$ re-osteosymblhese: fixateuremerne $\rightarrow$ chronische postranmatische osteitis.

$\rightarrow$ plat $\uparrow \rightarrow$ fe-osteosynulrese: $\mathrm{K} \cdot \mathrm{pen}+$ spongrosaplastick.

$\rightarrow$ phat $t \rightarrow$ spongiosaplastick + tactio.

$\rightarrow$ merosteosynthese: plat +sponguosaplastick $\rightarrow$ vertragede consolidatic + platabreuk $\rightarrow$ rem osteosynthose: plad * spongiosaplastick.

$\rightarrow$ spongiosaplastick.

$\rightarrow \mathrm{K}-$ pen $\uparrow+$ heupspica $\rightarrow$ chromisethe postresumethehe osteitis.

$\rightarrow$ reastoosynthese: K-pen

$\rightarrow$ Kopen $\mathbb{l} \rightarrow$ re-osteosynthes: plat $\rightarrow$ intectic med losmatory

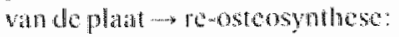
plase of fixmeur comerne? $\rightarrow$ veriragdo oonsolidatio $\rightarrow$ fixatetirexterne " t pongiosatplatstiok + tractic $\rightarrow$ duronische

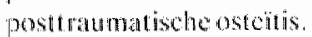

3 Van de 6 geinfecteerde osteosynthesen hebben geleid tot een chronische post traumatische osteilis. In de Grendelpengroep konden daarentegen posttraumatische ostertiden tot genezing gebracht worden.

\subsubsection{Vertraagde botgenezing}

In 11 gevallen ( $\mathrm{n}=38$ fracturen) was er sprake van een vertraagde botgenezing $(28.9 \%)$. In de Grendelpengroep trad slechts bij $7,7 \%(n=52$ fracturen) een vertraagde botgenezing op. 


\subsection{Samenvatting}

Bij de Heerlense osteosynthesen traden in $26,5 \%$ van de gevallen operatietechnische problemen op die voornamelijk te wijten waren aan de beperkingen van het osteosynthesemateriaal. Bij de Grendelpenosteosynthesen bleef het percentage operatieve problemen beperkt tot $16,4 \%$.

Opvallend is dat een patiènt met een Grendelpenosteosynthese zonder begeleidende letsels het been 54 dagen eerder partieel en 184 dagen eerder volledig kon belasten dan een vergelijkbare patiënt uit de Heerlense groep.

Helt posttraumatische osteittis percentage was in de Grendelpengroep met $7.7 \%$ duidelijk lager dan in de niet-Grendelpengroep met $17,6 \%$.

Vaak $(23,5 \%)$ was de primaire operatie bij de fracturen uit Heerlen niet voldoende om deze tot genezing te brengen. Voor de Grendelpenosteosynthesen lag dit percentage op $11.5 \%$.

$28.5 \%$ Van de Heerlense fracturen vertoonde een vertraagde botgenezing tegen slecht $7,7 \%$ van de Grendelpenosteosynthesen. 



\section{HOOFDSTUK 11}

\section{FUNCTIONELE EN ANATOMISCHE RESULTATEN}

\subsection{Looppatroon}

Bij het na-onderzoek werd gelet op het looppatroon en op het gebruik wan krukken, stokken en orthopaedische hulpmiddelen als loopapparaten, special schoejsel, hakwarhogingen etc. De patienten werden verzocht een stukje te lopen. warbij gelet werd op de symmetrie van het looppatroon (gelijke staplengte, verticale lichammsas), trekken met het been en het gebruik van een kruk of een stok. Wannear de patient zich bediende van halpmiddelen als kruk of stok of wameer het looppatroon niet vloeiend was, werd dit als abnormal beschouwd indien dit het gevolg was van het letsel van het bovenbeen. Van de Grendelpengroep had $90.2 \%$ een nomal looppatroon. Bij de andere technieken was dit percentage $72.7 \%$ (tabel 27). (De overleden en de niet na-onderzochte patiönten alsmede én paraplegische patient werden niet meegerekend).

Twbel27 1.ooppatmon

\begin{tabular}{|c|c|c|c|c|}
\hline & $\begin{array}{l}\text { Grombelpengroep } \\
(a=41 \text { pationten) }\end{array}$ & $(\%)$ & $\begin{array}{c}\text { Niet-Grondelpongtopep } \\
(\mathrm{n}=3.3 \text { pationten })\end{array}$ & $(\%)$ \\
\hline Nommad & 37 & $(00,2)$ & 24 & $(72.7)$ \\
\hline Abnormaal & 4 & $(4,8)$ & 9 & $(27.3)$ \\
\hline Gobnuik vankuk c. a. stok & 0 & & 3 & \\
\hline Oribupacdiseho hulpmiddeten & 2 & & 4 & \\
\hline
\end{tabular}

\subsection{Kniefunctie}

Het is een bekend gegeven dat na femurtracturen en vooral na distale fracturen vak een beperkte knicfunctic resteerl (Nicols 1963. Conolly 1973, wan Duyn 1977). Chamley (1947) en Damholt (1972) hebben angetoond dat cen lange consolidatieduur de voomaamste oorzat is voor het ontstan van een slechte kniefunctie. Het optreden van adhaesie"s en contracturen bimen het strekapparat word begunstigd door een vertragde botgenezing (Charnley 1947). In de studic van Tscherne (1977) had $24 \%$ wan de patiënten met meerfragmentlicturen ( $=$ 160 fracturen). die vrijwel allen met platen waren behandeld, een beperkte kniefunctie. Tscherne weet dit aan het feit. dat de meeste van deze patienten vaker geopereerd waren in verband met een vertraagde botgenezing enfol een postlratumatlische osteitis.

Om beperkingen van de kniefunctie te kunnen classificeren, werd de indeling van van Duyn (1977) gehanteerd (tabel 28 ). 


\begin{tabular}{|c|c|}
\hline zectgocd & $\begin{array}{l}\text { - flexie en extensievan beide knieén zijongelijk } \\
\text { - patient heeflgen pinklachten }\end{array}$ \\
\hline youd & - de flexic is minimaal $65^{\circ}$ \\
\hline & - de extensieheperking is maximad $10^{\circ}$ \\
\hline secht & - flexic minader dan $95^{\circ}$ \\
\hline & - extonsiebeperking meerdan $10^{\circ}$ \\
\hline & - pinklachten in rust of bif normalc belasting van de knie. \\
\hline
\end{tabular}

De resultaten blijken uit tabel 29. (De overleden patiënten, de niel na-onderzochte patiënten, de patiënten met dubbelzijdige femurfracturen en de patiënten waarbij begeleidende (homolaterale) letsels de oorzaak van cle slechte kniefunctie waren, werden niet meegerekend).

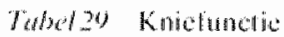

\begin{tabular}{|c|c|c|c|c|}
\hline & $\begin{array}{l}\text { Grendelpengrocep } \\
(1 \mathrm{n}=35 \text { piltientento })\end{array}$ & $(\%)$ & $\begin{array}{c}\text { Niat-Grendelpeneroep } \\
(n=30 \text { patienten })\end{array}$ & $(\%)$ \\
\hline Zher goed & 24) & $(82.9)$ & 22 & $(73,3)$ \\
\hline roced & 5 & $(101,3)$ & 4 & $(13.3)$ \\
\hline Slech & 1 & $(2.9)$ & 4 & $(1,3,3)$ \\
\hline
\end{tabular}

\subsection{Heupfunctic}

De beweeglijkheid van het heupgewricht werd onderzocht. De flexie-extensie, abadductie en exo-endorotatiefunctie van beide heupgewrichten werd gemeten en vergeleken. Een rechts-links versehil $\leqslant 10^{\circ}$ werd als niet alwijkend beschouwd. (De averleden patiënten, de niet natonderzochte patiënten, de patiënten met dubbelzijdige femurfacturen en de patiènten watabij begeleidende (homolaterale) letsels de oorzatik van de slechte heupfunctie waren. werden niet meegerekend.) De heupfunctic word in 4 groepen onderverdeeld (Bömer 1983) (1abel 30):

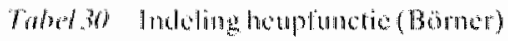

\begin{tabular}{|c|c|}
\hline Zourged & - geon hunctiobeperking in vergelijking met de andero kint. \\
\hline Cined & - gernge functichepenking van max. $20^{\circ}$ in tén wan de ondegache richtingen. \\
\hline Rouldijk & 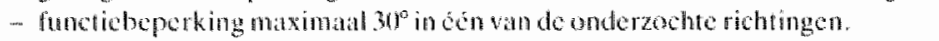 \\
\hline Slecht & - Thunctieheperking neer dan $30^{\circ}$ in ben van de onderawhe richtingen. \\
\hline
\end{tabular}




\begin{tabular}{|c|c|c|c|c|}
\hline & $\begin{array}{l}\text { Grendelpengroep } \\
(n=36 \text { patiönten })\end{array}$ & $(\%)$ & $\begin{array}{c}\text { Niet-Grendelpengroop } \\
(19=32 \text { patienten }\end{array}$ & $(\%)$ \\
\hline Zeergoed & 29 & $(80.6)$ & 24 & $(75.0)$ \\
\hline Goed & 3 & $(8.3)$ & 5 & $(15.6)$ \\
\hline Redelijk & 2 & $(5.6)$ & 3 & $(9.3)$ \\
\hline Slecht & 2 & $(56)$ & 0 & \\
\hline
\end{tabular}

2 Pafienten (F23G, F38G) hadden na een Girendelpenosteosynthese een slechte functie van het heupgewricht (tabel 31). Bij deze patienten was de slechte heup. functie warschijnlijk te wijten aan de postraumatische ostehis die cen zeer moejlijke en langdurige fracturbehandeling noodzakelijk mak te.

\subsection{Verschillen in femurlengte}

Alleen het vergelijkende röntgenologische onderzoek kan zekere inlormatie verschaffen omtrent een verschil in femurlengte en de ooraak daarvan. Beenlengte verschillen tot $1 \mathrm{~cm}$ geven nooit klinische symptomen en tot $2 \mathrm{~cm}$ zijn er meestal geen klachten (Morscher 1967). Een beenlengteverschil van meer dan $2 \mathrm{~cm}$ moet de patient corrigeren. Een verkorting tot $3 \mathrm{~cm}$ wordt gecorrigeend door een bekkenscheefstand. Bijgrotere verkortingen gat de patient met een spitsvoet lopen aan de kant van de verkorting en met een gebogen knie an de andere kant. Dit is bijzonder vermoeiend en op den duur ontstaat er een spits-holvoet met pijnlijke contracturen en een verkorting van de flexoren van de voet. Door het leit dat de patiënt constant met een gebogen knie van het andere been loopt, vall de mechanische as achter het kniegewricht, watardoor er een overbelasting van het strekapparat ontstat met op den duur een patello-femorale arthrose. De bekkenscheefsand veroorzaakt bovendien op den duur spondylarthotische verschijnselen op het niveau $L_{s}-S_{1}$ (Nicod 1967). In het algemeen ziel men bij een verkoring lot $2 \mathrm{~cm}$ geen reden om een corrigerende osteotomie uit te vocren (Zenker 1972. Mockwilz 1982). Bij beenverkortingen wan meer dan $2 \mathrm{~cm}$ is er, indien ook de palient dal wenst. cen indicatie yoor een verlengingsosteotomic. Volgens Lang (1967) kunnen verkortingen $1016 \mathrm{~cm}$ goed gecorrigeerd worden met een a angepaste schoen.

Bij het berekenen wan de lengte van beide lemora werden alleen meefgegevens gebruikt verkregen van de "Bein-Ganzaulnahmen" volgens Spirig (1967) die bij alke patiënt, die ter na-controle $\mathrm{kwam}$, werdengemak $\mathrm{L}$. Verschillen in lemurlengte $<1$ cm werden als niet afwijkend beschouwd, ondat zij geen klinische rolevantie he bben. De lengte van hel femur werd bepald door de loodlijn wan de bovenzijde vam de femurk op neer te laten op de lijn die de basis van de beide condylen verbind1. De resultaten van deze metingen zijn weergegeven in tabel 32 . 
Grendelpengroep

Niet-Grendelpengroep

$(n=36$ fraturen $\quad(\%) \quad(n=32$ fracturen $)$

Fomurlengle gelijik of

max. $1 \mathrm{~cm}$ verschil

29

5

Fenur $1 \mathrm{a} 2 \mathrm{~cm}$ werkort

2

$(80.5)$

23

$(13.8)$

(71.8)

Femur $>2 \mathrm{~cm}$ verkort

$(5.5)$

$(9.4)$

(De fracturen van de overleden patiënten en de niet na-onderzochte patiënten werden niet meegeteld. Ook de patiënten met dubbelzijdige femurfracturen werden buiten beschouwing gelaten.) 2 Fracturen uil de groep Grenclelpenosteosynthesen waren geconsolideerd met een verkorting van meer dan $2 \mathrm{~cm}$ :

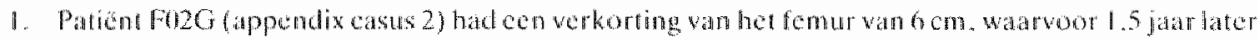
cen verkortingsustcotomie van 4.5 cm van het andere fenur werd verricht. Bij het na-onderzoek whog de pallient een schoenwerhoging van $2 \mathrm{~cm}$. Warmee geen bekkenschectstand atantwonbaw was. Ondanks bet feit dat er primair een statische vergrendeling werd verricht, was er een grote verkorting opgeteden. Bij retrospedic van de röntgenopnamen bijkt dat bij deze fractur met uitgebreide verbrifeling de aperateur de fractuar onvoldoende op lengte heeft gebracht

2. Patiën F4tG (appendix cakus 21 ) had een proximate fractur met tendens to werkortingen varusafwijing. De operateur probecrde de fractuur zoveel mogelijk op lengle ac brengen, hetgeen slecthes gedeettelijk lukte. Tevens blect cen lichte vantsalwijking bestan. Het feit dat de fractum niet volledig op lengte gebrak kon wordem. Was de vournatamste obrzak van de verkorting waman de $7^{\circ}$ varusafwijking slechts in gerioge mate bijdroeg.

Alle verschillen in lemurlengte bleken verkortingen te zijn. Wanneer de Grendelpenosteosynthesen met de andere technieken vergeteken worden, dan blijken in de Grendelpengroep $19,3 \%$ verkortingen van meer dan $1 \mathrm{~cm}$ te zijn opgetreden tegen $28,2 \%$ in de groep andere technieken.

\subsection{Asafwijkingen in het frontale vlak}

Varus- en valgusalwijkingen van de lemurschacht beinvloeden het statisch evenwicht doordat de belastingslijn die normaal door het midden van de knie loopt. meer natar mediaal respectievelijk naar lateraal verloopt. Een varusafwijking geeft een overbelasting van het mediale femoro-tibiale gewricht, watruit op den duur arthrotische alwijkingen met elongatie en instabiliteit van het laterale bandapparaat resulteren. De kans op het ontstaan van knieklachten neemt toe naarmate de afwijking distaler in cle schacht is gelocalliseerd. Varusafwijkingen van de dijbeenhats veroorzaken een verkorting van de pelvi-trochantere musculatuur met in extreme gevallen een positief Trendelenburgsymptoom. Een coxarthrose treed niet op (Nicod. Debrunner 1967). Meestal treden bij femurschachtfracturen varusafwijkingen op. Valgusafwijkingen zijn zeldzaam en worden vooral in het distale deel van de schacht gezien, met name bij supracondylaire fracturen. Bij een uitgesproken valgusalwijking loopt de patiënt het risico een gonarthrose van het laterale kniegewricht te ontwikkelen met instabiliteit van het mediale bandapparaat. Bij valgusafwijkingen van de dijbeenhals kan er op den duur een coxarthrose ontstan. 
Omtrent de indicaties voor corrigerende osteotomien waren Rehn (1968) en Mockwitz (1982) duidelijk. Zij beschouwden een varus- of valgusafwijking van $10^{\circ}$ als een operatie-indicatie. Nicod (1967) en Debrumer (1967) achtten bijeen varusafwijking eerder operatieve therapie aangewezen dan bij een valgusafwijking. omdat normalerwijze de knie ook aan valgusbelasting is blootgesteld. Wanneer de verbindingslijn tussen middelpunt van heup-en enkelgewricht door het meest medial gelegen deel van het kniegewricht verloopt en er tekenen van een beginnende arthrose zijn, achtten zij dit een operatie-indicatie. Wanneer de belastingslijn helemaal mediaal van het kniegewricht valt, bestaat er ook zonder arthrotische afwijkingen een operatie-indicatie. Valgusafwijkingen worden veel beter getolereerd en Nicod (1967) adwiseerde bij deze afwijkingen dan ook een afwachtende houding aan te nemen tot er klachten optreden.

A fwijkingen in het frontale vlak van minder dan $5^{\circ}$ zijn van geen belang en werden als niet afwijkend beschouwd (tabel 33). (De fracturen van de overleden patienten en van de niet na-onderzochte patiënten werden niet meegerekend. De fracturen van de patiënten met dubbelzijdige femurfracturen werden eveneens buiten beschouwing gelaten.)

Tabel 3.3 Varus-/valgusafwijkingen

\begin{tabular}{lcccc} 
& $\begin{array}{c}\text { Grendelpengroep } \\
(n=36 \text { fracturen })\end{array}$ & $(\%)$ & $\begin{array}{c}\text { Niet-Grendelpengroep } \\
(n=32 \text { fracturen })\end{array}$ & $(\%)$ \\
\hline $\begin{array}{l}\text { Varusatwijkingen } 5-10^{\circ} \\
\text { Varusatwijkingen }>10^{\circ}\end{array}$ & 7 & $(19,4)$ & 5 & $(15,6)$ \\
Valgusalwijkingen $5-10^{\circ}$ & 0 & & 0 & $(3,1)$ \\
Valgusafwijkingen $>10^{\circ}$ & 1 & $(2.7)$ & 1 &
\end{tabular}

Opvallend is het percentage lichte varusafwijkingen van 19,4\%. Dit is een probleem inherent atan de Grendelpentechniek.

Deze varusafwijkingen traden voornamelijk op bij proximale schacht fracturen en vooral wanneer er proximaal geen inklemming van de pen was. Wanneer de pen wel inklemt, biedt dit weerstand aan de varise rencle werking van de abductoren.

Patiënt F37G (appendix casus 15) is een voorbeeld van een fractuur met verbrijzeling van de proximale mediale cortex, waardoor de fractur in $10^{\circ}$ varus en $10^{\circ}$ antecurvatie werd gestabiliseerd.

Het percentage valgusafwijkingen $\geqslant 5^{\circ}$ van $2,7 \%$ steekt gunstig af tegen de $11,0 \%$ van Stapert (1983) bij 118 intramedullaire osteosynthesen.

Er zijn vrij veel lichte varusafwijkingen $(19,4 \%)$ bij de Grendelpenosteosynthesen. Deze $19,4 \%$ varusafwijkingen $\geqslant 5^{\circ}$ verschillen duidelijk met de $2,5 \%$ in Stapert's studie van 118 intramedullaire osteosynthesen.

De fracturen die met andere technieken werden behandeld, vertoonden in $15.6 \%$ van de gevallen een varusafwijking $\geqslant 5^{\circ}$.

$3.1 \%$ Van de fracturen uit deze groep was in een valgusstand $\geqslant 5^{\circ}$ geconsolideerd. 


\subsection{Asafwijkingen in het sagittale vlak}

Bij iedere patiënt werden foto's van beide femora in zijdelingse richting gemaakt. Aan de hand hiervan werd de aanwezige re- of antecurvatie bepaald. Consolidatie in sterke antecurvatie kan leiden tot een genu flexum. De belastingslijn loopt dan achter het kniegewricht, waardoor de M. quadriceps ook bij gewoon rechtop staan aangespannen moet blijven om passief buigen van de knie ten gevolge van de statische belasting te voorkomen, waardoor op den duur een pijnlijke contractuur van deze spier ontstaat. Bovendien ontstaat er door de buigstand van de knie een verhoogde druk in het patello-femorale gewricht, waaruit uiteindelijk een arthrosis van dit gewricht resulteert. Het achterste deel van het femoro-tibiale gewricht wordt sterk overbelast en ook hier treden op den duur arthrotische verschijnselen op (Nicod, Debrunner 1967). Een genu recurvatum ten gevolge van een fractuur van de schacht komt niet veel voor, wel bij supracondylaire fracturen (Nicod 1967). Van Duyn (1977) vond bij 8 van de 10 patiënten met een supracondylaire femurfractuur een recurvatiestand die in 2 gevallen groter dan $10^{\circ}$ was. Kootstra (1973) constateerde dat bij femurfracturen die behandeld waren met een Küntscherpen zonder opboren van de mergholte er veel patiënten waren met een lichte recurvatiestand van $5^{\circ}$ van het femur. Hij verk laarde dit uit het feit dat de fysiologische antecurvatie van de femurschacht door de rechte Küntscherpen werd veranderd in een lichte recurvatiestand. Tegenwoordig hebben de femurpennen allen een lichte antecurvatie overeenkomend met de gemiddelde antecurvatie van de femurschacht.

Mockwitz (1982) beschouwde een re- of antecurvatie van meer dan $10^{\circ}$ als een indlicatie voor een corrigerende osteotomie. Debrunner en Nicod (1967) waren meer terughoudend. Zij stelden dat de operatie-indicatie moet afhangen van de klachten van de patiënt en de functionele hinder. Een genu flexum van $25^{\circ}$ beschouwden zij als een absolute operatie-indicatie. Afwijkingen $<5^{\circ}$ werden als niet afwijkend beschouwd. De resultaten zijn weergegeven in tabel 34 (De fracturen van de overleden patiënten, van de niet na-onclerzochte patiënten en van de patiënten met dubbelzijdige femurfracturen werden niet meegerekend).

Tabel 34 Hockstanden in het sagittale wak

Grendelpengroep $(n=36$ fracturen $)$

\begin{tabular}{|c|c|c|c|c|c|}
\hline & Tracturen & $(\%)$ & & fracturen & $(\%)$ \\
\hline recurvatic $5-10^{\circ}$ & 1 & $(2.8)$ & untecurvatic $5-10^{\circ}$ & 1 & $(2.8)$ \\
\hline recurvatic $>10^{\circ}$ & 0 & & antecurvatio $>10^{\circ}$ & 1 & (2.8) \\
\hline
\end{tabular}

Niet-Grendelpengroep $(n=32$ fracturen $)$

\begin{tabular}{lcccc} 
& Tracturen & $(\%)$ & fracturen & $(\%)$ \\
\hline recurvatic $5 \times 10^{\circ}$ & 1 & $(3,1)$ antecurvatie $5-10^{\circ}$ & 3 & $(9,4)$ \\
recurvatic $>10^{\circ}$ & 2 & $(6,3)$ antecurvatie $>10^{\circ}$ & 0 & \\
\hline
\end{tabular}

Het percentage asafwijkingen van $8,4 \%$ in de Grendelpengroep komt overeen met de $10,4 \%$ die Stapert (1983) bij 115 intramedullaire osteosynthesen vond. Het per- 
centage asafwijkingen van $18,8 \%$ bij de andere technieken is hoog. Overeenstemmend met de bevindingen van van Duyn (1977) was, dat de fracturen die in sterke recurvatie waren geconsolideerd, atllen zeer distale (supracondylaire) schachtfracturen waren.

\subsection{Rotatie-afwijkingen}

Voor een normale gang is een exorotatie van $10^{\circ}$ van het femur noodzakelijk. Bij een exorotatie-afwijking moeten de endorotatoren bij iedere stap het been in de gewenste positie plaatsen. De totale kracht der endorotatoren is $1 / 10$ van die der exorotatoren, zodat het vrij spoedig tot overbelasting van deze spieren komt. Doordat de dijbeenhals in een onnatuurlijke retroversiepositie wordt gedwongen, treedt er een pijnlijke overrekking van het heupkapsel op (Weigert 1968). Volgens Nicod (1967). Mockwitz (1982) en Zenker (1967) wordt een exorotatie-afwijking tot $20^{\circ}$ zonder problemen in het heupgewricht gecorrigeerd. Grotere exorotatie-afwijkingen kan het heupgewricht niet compenseren en zullen op den duur tot klachten aanleiding geven. Een exorotatie-afwijking leidt niet tot een coxarthrose maar wel tot arthrotische veranderingen van het laterale femoro-tibiale gewricht (Nicod 1967). Endorotatie-afwijkingen worden vrijwel nooit gezien, maar geven eerder klachten (Zenker 1967). Bij een endorotatie-afwijking groter dan 15 a $20^{\circ}$ is een compensatie in het heupgewricht niet meer mogelijk en wordt de afwijking klinisch zichtbaar. Na verloop van jaren ontstat er een arthrose van het voorste deel van het heupgewricht; het kapsel-bandapparaat wordt continu overrekt waaruit uiteindelijk een pijnlijke instabiliteit resulteert (Nicod 1967). Wat betreft de knie ontstal er op den duur een genu varum met arthrose van het mediale compartiment (Nicod 1967). Debrunner (1967) heeft er op gewezen, dat een patellaire chondropathie ten gevolge van patello-femorale discongruentie vaak een van de eerste symptomen van een endorotatie-afwijking is.

Wanneer men rotatie-afwijkingen zeer nauwkeurig wil vaststellen, kan dit alleen met röntgenologische technieken (opname van het bekken volgens DunnRippstein (1955) of met de CT-scan). Hiervan werd in deze studie afgezien om budgettaire redenen. Rotatie-afwijkingen werden met behulp van klinisch onderzoek vastgesteld. Met de patiënt in buikligging werd het verschil in rotatiemogelijkheicl van beide heupen gemeten bij $90^{\circ}$ gebogen kniegewricht (Spirig 1967, van Joost 1972). Door de endo- en exorotatiemogelijkheid van beide heupen met elkaar te vergelijken, kan men endo- of exorotatie-afwijkingen van de femurschacht vaststellen.

Rotatie-afwijkingen van minder dan $10^{\circ}$ zijn bij klinisch onderzoek zeer moeilijk op te sporen en geven geen aanleiding tot klachten. Patiënten met een rotatie-afwijking tot $10^{\circ}$ werden derhalve als niet afwijkend beschouwd. De gegevens zijn vermeld in tabel 35. (De fracturen van de overleden patiënten, van de niet na-onderzochte patiënten en van de patiënten met dubbelzijdige femurfracturen werden niet meegerekend. Ook de fracturen van de patiënten waarbij andere letsels aanleiding gaven tot een rotatiebeperking in het heupgewricht werden niet meegeteld.) 
Grendelpengroep

$(n=32$ frackuren)

Gecr rotatie-afwijkingen

Rotatic-afwijking $10-20^{\circ}$

Rotatic-afwijking $>20^{\circ}$
Niet-Grendelpengroep

$(n=30$ fracturem $)$

(96.7)

29

0

0

Rotatie-afwijkingen van meer dan $20^{\circ} \mathrm{kwamen}$ bij de Grendelpenosteosynthesen niet woor. Dit resultaat is als goed te beschouwen, omdat slechts rotatie-afwijkingen van meer dan $20^{\circ}$ consequenties hebben voor de statiek van het been en het ontstaan van arthrotische veranderingen aan heup-en kniegewricht kunnen veroorzaken.

Bij patiënt F04G (appendix casus 3) was er ten tijde van het na-onderzoek een endorotatie-afwijking van $15^{\circ}$. Bij patiënt F20G was er een exorotatie-afwijking van $15^{\circ}$. Een duidelijke verkllaring voor beide rotatie-afwijkingen is er niet. Beide fracturen werden statisch vergrendeld en in de operatieverslagen werd geen melding gemaakt van peroperatieve problemen met betrekking tot de rotatie. Wanneer we het percentage rotatie-afwijkingen $>20^{\circ}$ van $0 \%$ bij de Grendelpenosteosynthesen vergelijken met de $47 \%$ van Stapert (1983) bij 107 intramedullaire osteosynthesen dan is dit verschil te verklaren uit het feit, dat de patiënten uit de Grendelpengroep allen in rugligging werden geopereerd, watarbij men meer controle heeft over de rotatiestand van het been. De belangrijkste reden is dat een statisch vergrendelde pen een veel grotere rotatiestabiliteit heeft, watardoor het optreden van secundaire rotatie-afwijkingen uitgesloten is.

\subsection{Arthrosis deformans}

Heup- en kniegewricht werden via radiologische criteria beoordeeld op de aanwezigheid van arthrosis deformans. Vier gradaties werden hierbij onderscheidden: geen, lichte, matige of ernstige afwijkingen (van Duyn 1977) (tabel 36 en 37).

Tabely Indeling arthrosis deformans (van Duyn)

Gicen

geco versmalling gew richtsspled geen selerose subchondrate bot geen osteopilyten.

Lichu : gecn versmalling gewrichtssplect lichte subchondrate selerose geen ostcophyten.

Ming : liche kersmalling gewrichesplect duidelijke solerose subchondrale bot kleine osteophyten.

Eransing : duidelijk versmalde gewrichtsspleet cystevorming subchondraal forse osteophyten. 
(De overleden patiënten en de niet na-onderzochte patiënten werden niet meegerekend, alsmede de patiënten waarbij andere letsels aanleiding gaven tot arthrosis deformans.)

Tabel 37 Arthrosis deformans

\begin{tabular}{|c|c|c|c|c|c|}
\hline & \multicolumn{2}{|l|}{ Heupgewricht } & \multicolumn{3}{|l|}{ Knicgewricht } \\
\hline & $\begin{array}{l}\text { Gineralelpen } \\
\text { groep } \\
(n=46 \\
\text { fractumen }) \quad(\%)\end{array}$ & $\begin{array}{l}\text { Niot-Grendelpen- } \\
\text { Erocp } \\
(n=32 \\
\text { fracturen } \quad(\%)\end{array}$ & $\begin{array}{l}\text { Grondelpen- } \\
\text { yroep } \\
(\mathrm{n}=41 \\
\text { meturen } \quad(7 /)\end{array}$ & $\begin{array}{l}\text { Nictorren } \\
\text { delpen } \\
(n=17 \\
\text { fricluen) }\end{array}$ & $\begin{array}{l}\text { Hpen- } \\
\text { rocep } \\
(x)\end{array}$ \\
\hline ernstig & - & - & - & - & \\
\hline matig & - & $(3,1)$ & - & 1 & 5.81 \\
\hline licht & - & - & - & 1 & $(5, x)$ \\
\hline $\operatorname{gec} n$ & - & - & - & - & \\
\hline
\end{tabular}

In de Grendelpengroep was er geen arthrosis deformans die te wijten was aan de Grendelpenosteosynthese of de complicaties daarvan. In de niet-Grendelpengroep was er éénmaal een matige coxarthrose (patiënt $\mathrm{H} / 1 \mathrm{~K}$ ), ten gevolge van een partiële femurkopnecrose die ontstaan was door een te mediaal ingebrachte Küntscherpen. Tweemaal was een gonarthrose aanwezig (patiënten HOIP en Hl1P) ten gevolge van een geïnfecteerde plaatosteosynthese en de late complicaties hiervan.

\subsection{Samenvatting}

De functionele resultaien waren in de Grendelpengroep beter dan bij de andere technieken. Zowel wat betreft looppatroon als wat betreft knie-en heuplunctie waren er verschillen ten gunste van de Grendelpenosteosynthesen: van de Grendelpenpatiënten had $90.2 \%$ een normaal looppatroon tegen $72,7 \%$ van de andere pattiënten. Een zeer goede knie- en heupfunctie had respectievelijk $82,5 \%$ en $80,6 \%$ van de Grendelpenpatiënten, tegen respectievelijk $73,3 \%$ en $75,0 \%$ van de patiënten die met andere technieken werden behandeld.

De anatomische resultaten verschilden in beide groepen alleen wat betreft het atantal beenverkortingen. Bij de Grendelpenpatiënten was er in $15,3 \%$ van de gevallen een verkorting van het femur van meer dan $1 \mathrm{~cm}$. Bij de andere patiënten was dit percentage $28,2 \%$.

Opvallend is dat bij de Grendelpenosteosynthesen geen rotatie-afwijkingen optraden, waarvoor de intramedullaire osteosynthesen in het algemeen berucht zijn. 

DEEL VI

ENKELE SOCIO-ECONOMISCHE ASPECTEN 


\section{HOOFDSTUK 12}

\section{SOCIO-ECONOMISCHE ASPECTEN}

3 Patiënten $(n=48$ patiënten $)$ uit de Grendelpengroep waren volledig arbeidsongeschikt. (Niet meegerekend werden de kort na operatie overleden patiënten.) Deze arbeidsongeschiktheid was niet het gevolg van de behandeling van de femurschachtfractuur, maar was ten gevolge van begeleidende letsels. Van de overige 45 patiënten waren er 41 werkzaam in hun oude beroep. 2 Patiënten waren werkloos, maar wel in staat hun beroep uit te oefenen. Eén patiënt was omgeschoold en één patiënt werd niet na-onderzocht. In totaal oefende $85,4 \%$ van de patiënten zijn oude beroep uit. De gemiddelde duur van de arbeidsongeschiktheid $(n=45$ patiënten) bedroeg 9 maanden.

In de niet-Grendelpengroep $(n=35$ patiënten) waren 9 patiënten volledig arbeidsongeschikt ten gevolge van het ongeval. Bij 6 van deze patiënten was de arbeidsongeschik theid alléén te wijten aan de late gevolgen van de femurfractuur (patiënten HIOK, HI4K, H0IE, H03P, H08P, H15P). Deze patiënten hadden of geen begeleidende letsels of er was een volledig herstel van deze letsels opgetreden.

De duur van de arbeidsongeschiktheid was in de niet-Grendelpengroep gemiddeld 20 maanden ( $n=26$ patiënten) (Niet meegerekend werden de overleden patiënten en de patiënten die blijvend arbeidsongeschikt waren). Dit is veel langer dan de gemiddelde arbeidsongeschik theidsduur van 9,17 maanden in Kootstra's serie (1973) van femurfracturen waarbij diverse behandelingen werden toegepast. Dit verschil kan verklaard worden uit het feit dat in deze studie alleen meerfragment-en etagefracturen werden opgenomen waarbij de patiënten gemiddeld meer ongevalsletsels vertoonden.

8 Van de 26 patiënten in de niet-Grendelpengroep, die niet blijvend arbeidsongeschikt waren, hadden een omscholing ondergatan. Dit betekent dat van de nog in leven zijnde patiënten ( $\mathrm{n}=35$ patiënten) $60 \%$ zijn oorspronkelijke beroep untoefende.

De paliënten uit de Grendelpengroep waren gemiddeld 11 maanden eerder aan het werk dan de patiënten waarbij andere technieken werden toegepast. Dit verschil kan gedeeltelijk worden toegeschreven aan het feit, dat de Grendelpentechniek met name bij dit soort fracturen een superieure techniek lijkt te zijn. Anderzijds is het zo dat de normen ter beoordeling van iemands arbeidsongeschik theid in WestDuitsland veel strenger zijn. Daar zijn het vooral objectieve criteria die de arbeidsongeschiktheid bepalen en niet zozeer het subjectieve klachtenpatroon van de patiënt, waarmee in Nederland veel meer rekening wordt gehouden. Bovendien nodigt het Duitse controlesysteem op ziekte en arbeidsongeschiktheid de patiënt veel minder uit tot misbruik van de sociale voorzieningen.

De gemiddelde leeftijd van alle bij dit onderzoek betrokken patiënten was $27,4 \mathrm{ja}$ ren. Een patient van die leefrijd met een modaal inkomen van $f 2.950$, - bruto, die volledig arbeidsongeschikt wordt $(80-100 \%$ W.A.O.), kost de Nederlandse Staat $f 1.274 .400,-$ aan uitkeringen tot atan zijn dood. Bij deze berekening werd er gemakshalve van uitgegaan, dat de patiënt 72 jaar wordt (dit is de gemiddelde leeftijd 
van een Nederlandse man volgens C.B.S.-gegevens over 1982) en dat zijn W.A.O.uitkering gelijk blijft en gecontinueerd wordt tot aan zijn dood (De W.A.O.-uitkering bij $80 \%$ arbeidsongeschiktheid is momenteel $f 2.360$, - bruto per maand berekend op basis van een modaal inkomen van $f 2.950,-$ bruto).

Wat een geïnfecteerde femurpseudarthrose alleen al aan verpleging kan kosten moge blijken als patiënt H14K met een geïfecteerde femurpseudarthrose na Küntscherpenosteosynthese als voorbeeld wordt genomen. Deze patiënt verbleef, verspreid over 5 jaren, 522 dagen in het ziekenhuis. Wanneer wordt uitgegaan van een gemiddelde verpleegprijs van $f 496,-$ per dag (gegevens C.B.S. over 1982), dan komen we op een bedrag van $f 273.732$,- alleen al aan verpleegkosten. Hierbij zijn niet inbegrepen de kosten van de diverse operaties, medicamenten, implantaten, orthopaedische hulpmiddelen, transport van en naar het ziekenhuis en van röntgen-en laboratoriumonderzoek.

Het is lofwaardig dat in het curriculum van de medische faculteit te Maastricht vanaf de allereerste bloktoets aandacht wordt besteed aan de economie van de gezondheidszorg. Deze lijn dient doorgetrokken te worden naar de curricula voor specialistenopleidingen; het economisch aspect van elke ingreep dient een onderdeel te vormen van de verwerving der specifieke bekwaamheden van iedere specialist. Het begrip levenskwaliteit, hoe vaag omschreven ook, dient hierbij niet uit het oog verloren te worden. Volgens Lemmens (1984) kan levenskwaliteit beschouwd worden als de exponent van creativiteit, met het daarbij onverbrekelijk verbonden gelluksgevoel. Creativiteit dient hierbij beschouwd te worden als de deelname aan dagelijkse levensactiviteiten aangepast per individu. Dit zal leiden tot een genuanceerdere en meer patiënt-gerichte benadering in plaats van een bepaald dogmatisme en automatisme hetgeen helaas nog te vaak voorkomt ten aanzien van de behandeling van patiënten in het algemeen en ongevalsletsels in het bijzonder. De economische winst zal berekenbaar zijn, de winst aan levenskwaliteit onberekenbaar groot.

Naast de verbetering van de operatietechniek en het osteosynthesematerial kunnen ook verkeerstechnische maatregelen ter preventie van ongevalsletsels getroffen worden. Bij motorrijders fungeert het menselijk lichaam als kreukelzône. De knie vangt bij een botsing valak de eerste klap op. Hierdoor kunnen ernstige letsels van knie. femur en heup ontstaan (Vollmar 1960). De montage van een valbeugel, die de knie beschermt, kan het aantal en de ernst van deze letsels sterk verminderen. Dit blijkt uit het feit, dat bij scooterrijders deze letsels nauwelijks voorkomen doordat zij direct in de valfase komen door het metalen scherm dat zich vóór de knieèn bevindt (Gögler 1968). De montage van een valbeugel zou een wettelijke verplichting moeten worden voor alle tweewielige motorvoertuigen. Het aantal en de ernst van knie-, femur- en heupletsels bij de berijders van deze voertuigen zou hierdoor verminderd kunnen worden.

Ook psychologische factoren zijn van belang. Het idealiseren van het motorrijden, zoals in reclame-advertenties voor motoren helaas gebruikelijk is, zou verboden moeten worden of op z'n minst zouden in de reclame-advertenties ook de risico's van het motorrijden vermeld moeten worden. Bij veel jongeren vormt de motor een cultus die het dagelijks leven grotendeels beheerst en heeft de liefde voor het motorvoertuig veel met eigen liefde te maken (Winter-Klemm 1983) 



\section{HOOFDSTUK 13}

\section{SAMENVATTING EN CONCLUSIES}

\subsection{Samenvatting en conclusies}

In deze studie worden meerfragment-en etagefracturen als een aparte groep bezien ondat deze fracturen moeilijk te behandelen zijn en in de weinige publicaties over dit ondewerpeen hoog percentage complicaties wordt angegeven. De gegevens van 89 patiënten met 93 van ceze fracturen uit een collectief van 458 patiënten met femurschachtfracturen zijn in deze studie verwerkt. Hiertoe werd door de auteur het patientenmateriaal uit de Berufsgenossenschaftliche Unlallklinik te Frankfort en uit het De Weverzieken huis te Heerten uitvoerig bestudeerd.

Vanat 1972 zijn in de Berufsgenossenschaftliche Unfallklinik alle femurschachtfracturen met een Grendelpen gestabiliseerd. Hierdoor is in de periode 1973-1981 een gesloten serie van 52 patienten ontstaan met 55 meerframent-en etagefracturen van de femurschacht. Als referentiekader zijn de gegevens van 37 patiënten met 38 soortgelijke fracturen, die in de periode 1974 - $198 \mathrm{~L}$ in het De Weverziekenhuis werden behandeld, bestudeerd. Deze patienten werden met verschillende technieken behandeld.

Het gebruik van operatieve en niet-operatieve technieken en combinaties van technieken was woomamelijk te wijten an het feit, dat het beschikbare osteosynlacsematerial onvoldoende mogelijkheden bood om bij deze fracturen én bepaalde techniek toe te passen. In dit opzicht zijn de behandelingsmethoden en de resultaten uit het De Weverziekenhuis waarschijnlijk representatiel voor de situatie in de meeste Nederlandse klinieken war men niet de beschikking heeft over de Grendelpen.

De resultaten van de Grendelpenosteosynthesen worden geplatst tegenover de resultaten van de andere behandellingstechnieken. Vanwege de relatieve zeldzaamheid van deze fracturen is het niet mogelijk elke techniek alzonderlijk te vergelijken met de Grendelpenosteosynthesen. Wel vormden de patiënten uit het De We. verziekenhuis een gesloten patiëntenreeks die in zijn totaliteit vergeleken kan worden met de Grendelpenosteosynthesen. Het is niet cle bedoeling absolute uitspraken te doen aan de hand van de verkregen resultaten in beide groepen. De opret wan dit onderzoek is te laten zien welke de resultaten van de Grendelpenosteosynthese $z i j n$ bij deze moeilijke fracturen.

In hoofdstuk 2 wordt de femurschacht gedelinieerd en wordt de indeling van femurschachtfracturen toegelicht.

In het kort wordt in hoofdstuk 3 het fracturtype en de ontstaanswijze van fracturen dangegeven. De wijze waarop bij verschillende verkeersdeelnemers cen lemurschachtfracture kan ontstaan, wordt toegelicht.

De voor-en nadelen van andere behandelingstechnieken worden in hooldstuk 4 opgesomd. Niet-operatieve behandelingstechnieken gaan gepaard met een hoog percentage vertraagde botgenezingen, re-fracturen en beenverkortingen. Boven- 
dien blifft er waak een beperkte kniefunctie bestaan en is de patiënt 3 tot 5 maanden in het ziekenhuis. Ook bij de operatieve technieken ontstaan regelmatig complicaties omdat conventionele platen en pennen niet geschikt zijn om deze complexe fracturen effectief te stabiliseren. Bovendien wordt door het aanbrengen van het osteosynthesemateriaal een groot additioneel trauma aan het bot en de weke delen toegevoegd.

Hoofdstuk 5 behandelt de arteriële doorbloeding van lange pijpbeenderen en de storingen die hierin optreden ten gevolge van fracturen. De invloed van verschillende osteosynthesetechnieken op de vascularisatie wordt besproken.

Aan de hand van gegevens uit experimentele studies worden de voordelen toegelicht, die een via de gesloten operatietechniek ingebrachte Grendelpen uit oogpunt van vascularisatie biedt.

Historische aspecten en achtergronden van intramedullaire osteosynthesen en in het bijzonder van de Grendelpen zijn ondergebracht in hoofdstuk 6.1.

Hoofdstuk 6.2. handelt over de biomechanische eigenschappen van de mergpen en de daarvan afgeleide Grendelpen. Met name het verschil tussen een Küntscherpen en een statisch vergrendelde pen is essentiëel. In het laatste geval moet het osteosynthese materiaal alle lasten dragen tot de fractuur geconsolideerd is.

Het indicatiegebied van de Grendelpen vormt het thema van hoofdstuk 6.3. Met deze techniek kunnen fracturen vanaf de trochanter minor tot $6 \mathrm{~cm}$ boven de kniespleet behandeld worden. Bovendien is de techniek zeer geschikt om pseudarthrosen en pathologische fracturen te behandelen en om corrigerende osteotomiën uit te voeren. De begrippen dynamische en statische vergrendeling en de specifieke indicaties voor deze twee technieken worden uiteengezet.

Hoofdstuk 6.4. behandelt de vraag of het de voorkeur verdient een intramedullaire osteosynthese via de open of de gesloten operatietechniek te verrichten. Op grond van literatuurgegevens wordt geconcludeerd dat gestreeld moet worden naar een gesloten operatietechniek.

In hoofdstuk 6.5. komt de operatietechniek uitvoerig aan de orde. De ligging van de patiënt op de rektafel wordt besproken. Een goede ligging op de rektafel is essentièel voor het slagen van de operatie. De operatietechniek wordt stapsgewijs besproken. Voor de twee in de handel zijnde systemen wordt de operatietechniek beschreven.

In hoofdstuk 6.6. wordt de nabehandeling van een Grendelpenosteosynthese aangegeven.

De operatietechniek van de Grendelpen is niet eenvoudig. In hoofdstuk 6.7. worden systematisch de problemen besproken die bij de operatie kunnen optreden en wordt aangegeven hoe deze problemen te vermijden of op te lossen zijn. 
Hoofdstuk 7 is gewijd aan de gevolgde procedure bij het na-onderzoek en het opsporen van de patiënten. De ten tijde van het na-onderzoek overleden patiẻnten en de niet na-onderzochte patiënten worden apart besproken.

In hoofdstuk 8 vindt een analyse van het patiëntenbestand plats. $70 \%$ Van de patiënten was ten tijde van het ongeval tussen de 16 en 35 jatar. $86.5 \%$ Van de patiënten was het slachtoffer van een verkeersongeval. Dit hoge percentage is te verklaren uit het feit, dat meerfragment-en etagefracturen meestal ten gevolge van grote krachten zoals bij verkeersongevallen ontstaan. In totaal bleken $22,6 \%$ van de fracturen open te zijn. Voor alle patiënten werd de Injury Severity Score berekend.

De gemiddelde I.S.S. was 27,7 . Van alle patiënten had $73 \%$ begeleidende letsels. Deze letsels werden verdeeld naar letsels van algemene aard en specifieke homolaterale letsels. $41,5 \%$ Van de patiënten vertoonde een begeleidend schedel-hersentrauma, $11,2 \%$ een heterolaterale femurfractuur en $23.7 \%$ een homolaterale onderbeenfractuur.

De hoofdstukken 9 en 10 geven de behandelingsresultaten weer die bij de Grendelpenosteosynthesen zijn behaald. Deze gegevens worden vergeleken met de resultaten van de andere technieken. In de Grendelpengroep waren er in $5,4 \%$ van de gevallen technische problemen tijdens de operatie die de reposilie of de stabiliteit blijvend beïnvloedden. In de niet-Grendelpengroep was dit percentage $26.5 \%$. Er zijn een aantal grensindicaties voor de toepassing van een Grendelpen. De hierbij toegepaste technieken worden aangegeven en van commentaar voorzien. Met name een gecombineerd letsel van dijbeenhals en femurschacht kan met een Grendelpen efficiënt behandeld worden. Het tijdstip waarop het been partieel en volledig belasi kon worden, bleek bij een Grendelpenosteosynthese gemiddeld 37 en 118 dagen eerder te zijn dan bij de patiënten die met andere technieken behandeld werden.

De fracturen met een Grendelpenosteosynthese waren gemiddeld 4 maanden eerder geconsolideerd dan de met andere technieken behandelde fracturen. Met betrekking tot de postoperatieve complicaties waren er hele duidelijke verschillen ten gunste van de Grendelpen zeker met betrekking tot het percentage osteïtis en vertraagde botgenezing. In de groep Grendelpenosteosynthesen kwamen deze complicaties beduidend minder voor. Dit verschill kan verklaard worden wit het leit dat de Grendelpen meer stabiliteit biedt bij een geringer operatietrama. Het percentage fracturen met een vertraagde botgenezing van $7,7 \%$ is laag in vergelijking met in de literatuur gepubliceerde gegevens van plaatosteosynthesen voor soortgelijke fracturen.

Hoofdstuk 11 is gewijd aan de functionele en anatomische resultaten.

De functionele resultaten waren bij de Grendelpenpatiënten beter dan bij de andere patiënten. De anatomische resultaten verschilden wat beide groepen beireft niet opvallend met gegevens uit andere studies. Bij de Grendelpenosteosynthesen werden in $20 \%$ van de gevallen lichte varusafwijkingen gezien. Dit is typisch voor de Grendelpen met name bij proximale fracturen wanneer de pen geen inklemming heeft in het proximale hoofdfragment. Opvallend is dat rotatie-afwijkingen, die frequent gezien worden bij andere intramedullaire osteosynthesetechnieken, bij de Grendelpen niet voorkwamen. 
Enkele socio-economische aspecten komen in hoofdstuk 12 aan de orde.

Het valt op dat de patiënten met een Grendelpenosteosynthese gemiddeld 11 maanden eerder aan het werk waren dan de andere patienten. Dit verschil wordt zeker door de andere arbeidsmorall van de Duitsers en het strenge controlesysteem op arbeidsongeschiktheid, dat in West-Duitsland gehanteerd wordt, beinvloed.

$16 \%$ Van de niet-Grendelpengroep was wolledig arbeidsongeschikt ten gevolge van complicaties van de fractuurbehandeling. Geen van de Grendelpenpatiënten daarentegen was blijwend arbeidsongeschikt ten gevolge van de fractuur.

De eigenlijke waarde van een bepaalde osteosynthesetechniek in de behandeling van femurschachtfracturen blijkt uit de resultaten die behaald worden in de behandeling van moeilijke, d.w.z. meerfragment- en etagefracturen. De conclusie die men aan dit proefschrift kan verbinden is, dat de Grendelpen bij uitstek geschikt is voor de behandeling van alle femurschachtfracturen. Met de Grendelpen heeft men de beschikking over een universele techniek waarmee alle femurschachtfracturen behandeld kunnen worden en waarmee ook bij moeilijke fractuurvormen goede resultaten verkregen kunnen worden, vooral wanneer men bedenkt voor welke problemen deze fracturen de chirurg in het verleden platste. 


\subsection{Summary and conclusions}

In this study, comminuted and segmental fractures of the femoral shaft have been considered as a single group because they are both difficult to treat and the small number of publications available on the subject indicate a high percentage of complications. For the purpose of this study. data were collected on 89 patients with 93 such fractures, selected from a total of 458 case histories. The author has made a detailed study of case histories of the Berufsgenossenschaftliche Unfallklinik in Frankfurt and of the De Wever Hospital in Heerlen. Since 1972, all fractures of the femoral shaft at the Berutsgenossenschaftiche Unfallklinik have been stabilised by means of the interlocking nail, so that a homogeneous group of 52 patients with 55 comminuted or segmental femoral shaft fractures was obtained between 1973 and 1981 . The case histories of 37 patients treated at the Wever Hospital between 1974-1981 for fractures of this type were used as a reference group. These patients were treated by various methods. The use of operative, non-operative or combined techniques was mainly due to the fact that the available osteosynthesis material provided insufficient possibilities for application of one specific technique for treatment of all these fractures. In this respect, the results obtained at the De Wever Hospital are probably representative for most Dutch hospitals.

The results of the interlocking nail osteosynthesis thave been compared to the results obtained by means of other techniques. Due to the fact that these types of fracture are relatively rare, it has not been possible to make separate comparisons between the interlocking nail and each of the other techniques. The total number of De Wever Hospital patients nonetheless constituted a homogeneous group comparable with the patients who underwent interlocking nail osteosynthesis. It is not the author's intention to draw hard and fast conclusions on the basis of the results in these two groups. The object of this study is to describe the excellent results obtained by means of interlocking nail osteosynthesis.

The femoral shaft is defined in chapter 2 and an explanation is given concerning the categorisation of femoral shaft fractures.

Chapter 3 deals with the accident pattern which causes such fractures. The manner in which femoral shaft fractures can occur in different accidents is also explained.

The advantages and disadvantages of other techniques are summarised in chapter 4. The literature reveals that non-operative treatment results in a high percentage of delayed union, refracturing and shortening of the leg. Furthermore, kneefunction is often impaired and patients are confined to hospital for periods varying between 3 and 5 months.

Complications also occur regularly as the result of operative techniques. This is mainly due to the fact that conventional nails and plates are not suitable for efficient stabilisation of these complex fractures. In addition, application of the osteosynthesis material causes considerable supplementary trauma to both the bone and the soft tissues. 
Chapter 5 discusses the blood circulation in long bones and the circulatory malfunctions which can be caused by fractures. The effect of various osteosynthesis techniques on vascularisation is discussed. On the basis of data obtained from experimental studies, the advantages of application of the interlocking nail by means of closed operative techniques are explained from the vascularisation angle.

The historical aspects and background of intramedullary osteosynthesis and, in particular, of the interlocking nail technique are handled in chapter 6.1 .

Chapter 6.2. concerns the biomechanical properties of the intramedullary nail and the interlocking nail developed from it. There are a number of important differences. In particular, the difference between a Kuntscher nail and a static interlocked nail is of essential importance. In the case of the latter, the osteosynthesis material has to bear the full stress until the fracture has healed.

The indications for the interlocking nail are the subject of chapter 6.3 . It appears that this technique is suitable for the treatment of fractures in the area between the trochanter minor and a point $6 \mathrm{~cm}$ above the knee-joint. Furthermore, the technique is highly suitable for treatment of pseudorthroses and pathological fractures and for correction osteotomies. The concepts of dynamic and static interlocking and the specific indications for these two techniques are defined.

Chapter 6.4. is dedicated to the discussion of whether it is preferable to practice intramedullary osteosynthesis by means of open or closed operative techniques. The author is of the opinion that preference should be given to the closed operative technique whenever possible.

The advantages and disadvantages of the operative techniques are handled in detail in chapter 6.5. The various positions on the extension table are discussed. A good position on the extension table is essential for the success of the operation. The successive procedures duting the operation are discussed stage by stage and the operative techniques for the two commercially available systems are described.

Chapter 6.6. gives a bricf description of the follow-up treatment of interlocking nail osteosynthesis.

The interlocking nat technique is not simple. Chapter 6.7 . provides a systematic review of the problems which can arise during the operation with an indication of the manner in which they can be avoided or solved.

Chapter 7 concerns tracing patients and the procedure followed during the followup examination. Both the patients who had died before the time the follow-up examination was planned and those who did not undergo such an examination (for other reasons) are discussed separately.

Chapter 8 provides an analysis of the patient group. At the time of their accident, $70 \%$ of the patients were aged between 16 and $35.86 .5 \%$ of the patients were 
victims of roadtraffic accidents. This high percentage can be explained by the fact that comminuted and segmental fractures usually occur as the result of heavy impact as is the case in such accidents. A total or $22.6 \%$ of the injuries appeared to consist of open fractures. The Injury Severity Score was calculated for all patients. The average I.S.S. was 27.7 and $73 \%$ of the patients suffered additional lesions. These lesions were divided into those of a general nature and specific homolateral lesions. $41.5 \%$ of the victims suffered brain concussion, $11.2 \%$ had heterolateral femoral fractures and $23.7 \%$ homolateral fractures of the lower leg.

Chapters 9 and 10 give the results obtained by means of interlocking nail osteosynthesis. These results are compared to those obtained by means of alternative techniques. $5,4 \%$ of the patients in the interlocking nail group presented technical problems during the operation which had effects on reposition or stability of the fracture. This percentage in the non-interlocking nail group was $26.5 \%$. There are a number of borderline indications for the interlocking nail. The techniques used in such cases are indicated with comments. A combined fracture of the neck and the shaft of the femur, for example, is particularly well suited for interlocking nail osteosynthesis.

The time before the leg could carry partial (of full) weight averaged 37 (or 118) days less with the interlocking nail than with the other techniques. Fractures treated by means of the interlocking nail healed, on average, 4 months earlier than fractures treated by means of alternative technicjues. With regard to post-operative complications, there were clear differences in favour of the interlocking nail in relation to the development of osteitis and delayed union. These complications occurred far less frequently in the patients treated by the interlocking nail. This difference can be explained by the fact that the interlocking nail provides greater stability and causes less operative trauma. The percentage of 7.7 for fractures with delayed union is low in comparison with the figures published in the literature for plate osteosynthesis of similar fractures.

Chapter 11 is dedicated to the functional and anatomical results. The functional results were better in the interlocking nail patients. The anatomical resuls for both groups varied only slightly from those obtained in other studies. Slight varus deformity was noted in $20 \%$ of the interlocking nail patients. This is typical for the interlocking nail. particularly in the case of proximal fractures, when the nail is not elastically wedged in the main proximal fragment. It is worthy of note that the rotation problem frequently resulting from other intramedullary osteosynthesis techniques was totally absent in the interlocking nail group.

A number of socio-economic aspects are dealt with in chapter 12.11 is interesting to observe that the patients treated by means of the interlocking nail were back at work, on average. 11 months earlier than the other patients. This difference is certainly due in part to a different attitude towards work among the Germans, as well as to the strict control on disablement exercised in West Germany. A rotall of $16 \%$ of the non-interlocking nail patients were permanently disabled as a result of complications of the treatment of their fractures. Whereas none of the interlocking nail patients were permanently disabled as a result of the fracture treatment. 
Assuming that the intrinsic value of a specific osteosynthesis technique for the treatment of femoral shaft fractures can be assessed by the results obtained by treatment of difficult cases, i.e. the comminuted and segmental fractures, the conclusion reached in this thesis is that the interlocking nail is particularly wellsuited for treatment of all femoral shaft fractures. The interlocking nall provides a universal technique for the treatment of such fractures and also provides good results in the presence of difficult fractures, especially when the problems which these fractures formerly presented to surgeons are taken into consideration. 


\subsection{Zusammenfassung und Schlussfolgerungen}

In dieser Studie werden Mehrfragment- und Etagenfrakturen als eine gesonderte Gruppe angesehen, da diese Frakturen schwierig zu behandeln sind und in den wenigen Veröffentlichungen äber dieses Thema ein hoher Prozentsatz an Komplikationen angegeben wird. Die Daten von 89 Patienten mit 93 dieser Femurschaftfrakturen aus einer Gesamtgruppe von 458 Patienten sind in dieser Studie verarbeitet. Hierzu hat der Autor das Patientenmaterial aus der Berufsgenossenschaftlichen Unfallklinik in Frankfurt und aus dem De Wever-Krankenhaus in Heerlen eingehend untersucht.

Ab 1972 wurden in der Berufsgenossenschaftlichen Unfallklinik alle Femurschaftfrakturen mit einem Verriegelungsnagel stabilisiert, wodurch im Zeitraum von 1973 bis 1981 eine geschlossene Serie von 52 Patienten mit 55 Mehrfragment- und Etagenfrakturen des Femurschaftes entstanden ist. Als Bezugsrahmen dienten die Daten von 37 Patienten mit 38 gleichartigen Frakturen, die im Zeitraum von 1974 $1981 \mathrm{im}$ De Wever-Krankenhaus behandelt wurden.

Bei diesen Patienten wurden verschiedene Behandlungstechniken angewandt. Die Anwendung von operativen und nichtoperativen Techniken und die Kombination von Techniken war vornehmlich auf die Tatsache zurückzuführen, dass das verfügbare Osteosynthesematerial ungenügende Möglichkeiten bot, um bei diesen Frakturen eine ein heitliche Technik anzuwenden.

In dieser Hinsicht sind die Ergebnisse aus dem De Wever-Krankenhaus wahrscheinlich für die Situation in den meisten niederländischen Kliniken repräsentativ, wo man nicht über den Verriegelungsnagel verfügt. Die Ergebnisse der Verriegelungsnagelosteosynthesen wurden den Ergebnissen anderer Behandlungstechniken gegenübergestellt. Wegen der relativen Seltenheit dieser Frakturen ist es nicht möglich, jede Technik einzeln mit den Verriegelungsnagelosteosynthesen zu vergleichen. Wohl aber bildeten die Patienten aus dem De Wever-Krankenhaus eine geschlossene Patientengruppe, die in ihrer Gesamtheit mit den Verriegelungsnagelosteosynthesen verglichen werden kann. Es wird nicht bezweckt, anhand der erzielten Resultate in beiden Gruppen absolute Aussagen zu machen. Diese Untersuchung soll vielmehr zeigen, welche Ergebnisse die Verriegelungsnagelosteosynthese bei diesen schwierigen Frakturen erbracht hat.

In Kapitel 2 wird der Femurschaft definiert, und es wird die Einteilung von Femurschaftfrakturen erläutert.

In Kapitel 3 werden kurz Frakturtype und Entstehung von Frakturen aufgezeigt. Die Art und Weise, wie bei verschiedenen Verkehrsteilnehmern eine Femurschaftfraktur entstehen kann, wird erläutert.

In Kapitel 4 werden die Vor- und Nachteile verschiedener Behandlungstechniken aufgezählt. Die nichtoperative Behandlung geht einher mit einem hohen Prozentsatz an verzögerten Knochenheilungen, mit Retrakturen und Beinverkürzungen. Des weiteren bleibt oft die Funktionsfähigheit des Knies eingeschränkt, und der Patient befindet sich 3-5 Monate im Krankenhaus. Auch bei den operativen Techniken wird man regelmässig mit Komplikationen konfrontiert. Dies ist vornehmlich auf die. Tatsache zurückzuführen, dass konventionelle Platten und Nägel nicht 
geeignet sind, um diese komplexen Frakturen auf effektive Weise zu stabilisieren. Ausserdem wird beim Anbringen des Osteosynthesematerials ein grosses zusătzliches Trauma am Knochen und den Weichteilen hinzugefügt.

Kapitel 5 behandelt die arterielle Durchblutung von langen Röhrenknochen und deren Störungen, dié bei Frakturen auftreten. Der Einfluss verschiedener Osteosynthesetechniken auf die Vaskularisation wird besprochen. Anhand von Daten aus Experimentalstudien werden die Vorteile erläutert, die ein über die geschlossene Operationstechnik eingebrachter Verriegelungsnagel wom Gesichtspunkt der Vaskularisation aus bietet.

Historische Aspekte und Hintergründe der intramedullären Osteosynthesen im Algemeinen und des Verriegelungsnagels im besonderen sind in Kapitel 6.1 beschrieben.

Kapitel 6.2. behandelt die biomechanischen Eigenschaften des Marknagels und des davon abgeleiteten Verriegelungsnagels. Es gibt einige wesentliche Unterschiede zwischen beiden, wobei namentlich dem Unterschied zwischen einem Küntschernagel und einem statisch verriegelten Nagel grosse Bedeutung zukommt. Im letzten Fall muss das Osteosynthesematerial die wolle Last tragen, bis die Fraktur geheilt ist.

Das Anwendungsgebiet des Verriegelungsnagels wird behandelt in Kapitel 6.3. Mit dieser Technik können Frakturen ab dem Trochanter minor bis $6 \mathrm{~cm}$ oberhalb des Kniegelenkspalts behandelt werden. Ausserdem eignet sich diese Technik sehr gut zur Behandlung von Pseudarthrosen und pathologischen Frakturen und zur Durchlührung von korrigierenden Osteotomien. Die Begriffe dynamische und statische Verriegelung und die spezifischen Indikationen für diese zwei Techniken werden erläutert.

Kapitel 6.4. beschäftigt sich mit der Frage, welche Technik bei der intramedullären Osteosynthese den Vorzug verdient, die offene oder die geschlossene Operationstechnik. Der Autor vertritt die Ansicht, dass die geschlossene Operationstechnik anzustreben ist.

In Kapitel 6.5. wird die Operationstechnik ausführlich behandelt. Weiterhin werden die Vor- und Nachteile der verschiedenen Liegepositionen auf dem Extensionstisch besprochen. Eine gute Lage ist für das Gelingen der Operation von grösster Bedeutung. Die aufeinanderfolgenden Handlungen werden schrittweise besprochen. Für die zwei in Handel befindlichen Systeme wird die Operationstechnik beschrieben.

In Kapitel 6.6. wird die Nachbehandlung einer Verriegelungsnagelosteosynthese kurz abgehandelt.

Die Verriegelungsnageltechnik ist nicht völlig unproblematisch. In Kapitel 6.7. werden systematisch die Probleme besprochen, die bei der Operation auftreten können, und es wird angegeben, wie diese Probleme sich vermeiden oder lösen lassen. 
Kapitel 7 ist dem Ermitteln der Patjenten und der bei der Nachuntersuchung befolgten Prozedur gewidmet. Die zum Zeilpunkt der Nachuntersuchung verstorbenen Patienten und die nicht nachuntersuchten Patienten werden gesondert besprochen.

In Kapitel 8 wird eine Analyse des Patientenbestandes durchgefuhrt. $70 \%$ der Patienten waren zum Zeitpunkt des Unfalls zwischen 16 und $35 \mathrm{Jahre}$ alt. $86.5 \%$ der Patienten war bei einem Verkehrsunfall verletzt worden. Dieser hohe Prozentsatz erklärt sich aus der Tatsache, dass Mehrfragment- und Etagenbrüchen meistens als Folge grosser Krafteinwirkungen entstehen, wie dies bei Verkehrsunfällen der Fall ist. Bei insgesamt 22,6\% der Frakturen handelte es sich um offene Bruche. Für alle Patienten wurde der sog. "Injury Severity Scone" berechnet. Der dumchschnittliche I.S.S. lag bei 27,7. Von den Patienten hatte $73 \%$ zusätzliche Verletzungen. Diese Verletzungen wurden gegliedert in solche allgemeiner Art und in spezifische homolaterale Verletzungen. 41,5\% der Patienten wies ein zusätzliches Schadel-Gehirn. trauma auf. $11,2 \%$ hatte eine heterolaterale Femurfraktur und $23,7 \%$ eine homolaterale Unterschenkelfraktur.

Die Kapitel 9 und 10 geben die Ergebnisse wieder, die bei Verriegelungsnagelosteosynthesen erzielt wurden. Diese Amgaben wurden mit den Ergebnissen anderer Techniken werglichen. In der Verriegehungsnagelgruppe waren es in $5,4 \%$ der Fille technische Probleme während der Operation, die die Reposition oder die Stabilität beeinflussten. In der Nicht-Verriegelungsnagelgruppe lag dieser Prozentsatz bei 26,5\%.

Es gibt eine Anzahl von Grenzindikationen für die Anwendung eines Verriegelungsnagels. Die angewandten Techniken werden jeweils angegeben und mil einem Kommentar versehen. Besonders die Kombination von Schenkellhalis- und Fermurschaftfraktur kann mit einer Verriegelungsnagelosteosynthese effektiv behandelt werden.

Der Zeitpunkt; zu dem das Bein partiell bzw. vollständig belastet werden konnte, lag bei einer Verricgelungsnagelosteosynthese durchschnitlich 37 bzw. 118 Tage früher, als bei mit anderer Techniken behandelten Frakturen. Hieraus kann man folgern, dass die Frakturen mil einer Verriegelungsnagelosteosynthese durchm schnittich 4 Monate eher geheilt waren, ats beiden anderen Frakturen"

In Bezug auf postoperative Komplikationen gibu es ganz deulliche Unterschiede zugunsten des Verriegelungsnagels, und zwar was den Prozentsatzan Osteitis und verzögerte Knochenheilung betrift. In der Gruppe Verriegelungsnagelosteosynthesen kommen diese Komplikationen bedeutend weniger vor. Dieser Unterschied beruht daraul, dass der Verriegelungsnagel mehr Stabilitä bei einem geringeren Operationstrauma bietet. Der Prozentsatz von Frakturen mit ciner verzögerten Knochenheilung liegt mit $7,7 \%$ im Vergleich $\mathrm{zu}$ in der Literatur veröfentichen Angaben von Plattenosteosynthesen für gleichartige Frakturen niedrig.

Kapitel 11 ist den funktionellen und anatomischen Ergebnissen gewidmet. Die funktionellen Ergebnisse sind bei den Patienten mit Verriegelungsnagel besser als bei den anderen Patienten. Die anatomischen Ergebnisse unterscheiden sich bei beiden Gruppen nicht auffallend von den Angaben aus anderen Studien. Bei den Verriegelungsnagelosteosynthesen wurden in $20 \%$ der Falle leichte Varusabwei- 
chungen festgestellt. Dies ist typisch für den Verriegelungsnagel, namentlich bei proximalen Frakturen, wenn der Nagel im proximalen Hauptfragment keine Einklemmung hat.

Auffallend ist, dass Rotationsabweichungen, die bei anderen intramedullären Osteosynthesetechniken des öfteren festgestellt wurden, beim Verriegelungsnagel nicht auftreten.

Einige soziale und wirtschaftliche Aspekte kommen in Kapitel 12 an die Reihe. Es fällt auf, dass die Patienten mit einer Verriegelungsnagelosteosynthese durchschnitulich 1I. Monate eher wieder zur Arbeit erschienen, als dies bei den anderen Patienten der Fall war. Dieser Unterschied wird möglicherweise auch durch die andere Arbeitsmoral der Deutschen und durch das strenge westdeutsche Berufsunfähigkeitskontrollsystem beeinflusst. $16 \%$ der Nicht-Verriegelungsnagelgruppe war infolge von Komplikationen bei der Frakturbehandlung vollständig erwerbsunfähig. Dagegen war keiner der Verriegelungsnagelpatienten infolge der Fraktur bleibend erwerbsunfahig.

Wenn man davon ausgeht, dass sich der wirkliche Wert einer bestimmten Osteosynthesetechnik für die Behandlung von Femurschaftfrakturen an den bei der Behandlung von schwierigen, d.h. Mehrfragment- und Etagenfrakturen erzielten Ergebnissen zeigt, so kann die Schlussfolgerung aus den Ergebnissen dieser Dissertation nur lauten, dass der Verriegelungsnagel für die Behandlung aller Femurschaftfrakturen ausgezeichnet geeignet ist. Mit dem Verriegelungsnagel verfügt man über eine universelle Technik, mit der alle Femurschaftfrakturen behandelt werden können, und mil der auch bei schwierigen Frakturformen gute Ergebnisse erzielt werden, besonders wenn man bedenkt, vor welchen Problemen der Chirurg in der Vergangenheit bei diesen Frakturen stand. 


\section{Literatuur}

- Ahlers, J.: Ritter, G.: Weigard. H. (1983): Dic Marknagelung als Sekundäreingriff nach vorausgeganger Anwendung des Fixateur Externe. Unfallehirurgie $2: 83$.

- Alho. A. (1980): Injuries in the temoral axis. Int. Orthopaedics (Sicot) 3:271.

- Altenberg. A.; Shorkey. R. (1949): Blade plate fixation in non-union and in complicated fractures of the supracondylar region of the femur. J. Bone Joint Surg. 31-A:312.

- Amihood. S. (1973): Analysis of 200 fractures of the femoral shaft treated at Groote Schutur Hospital. Injury. $5: 35$.

- Ansorge. D. (1982): Die Behandlung der kombinierten Schenkelhals-Fomurschat tbrüche mit dem Verricgettngsmagel. Zentralbl. Chir. $107: 515$.

- Autt"n Ordt. M.: Retrig. H. (1975); Dic Valgusdeformitä des Schenkelhalses als Spanfolge nach Oberschenkelmarknagelung beim Kind. Akt. Traum. $5: 163$.

- Baker. S.; ONeill, B.; Haddin. W.: Long. W. (1974): The injury severity score. a method for veseribing paticnts with multiple injuries and evaluating energency care.

1. Trauma, voll. 14.3: 187.

- Baltensweiler. J. (1975): Die geschlossene Marknagelung als Standardoperation bei Unterschenkeltrakturen. Hefie Unfallheilkunde 119:67.

- Bardenheuer. B. (1875): Citaat uit: Brans. P. (1886): Die Lehre von den Knochenbruchen. Ed... Enke. Stuttgart.

Barron. S.; Robb. R.; Taylor. W.: Kelly, P. (1977): The effect of fixation with intrandedullary rods and plates on fraeture-site blood flow and bone remodeling in dogs. J. Bone Joint Surg. 59-A:376.

- Bauer, K. (1943): Marknagelung oder Drahtextension? Zentrabi. Chir. 70: 254.

- Bäuerle, E. (1976): Offene und gedeckte Technik der Marknagelung. Akt. Traum. 6: 369.

- Bechtol. C. (1952): Engineering principles applied to orthopaedic surgery in: Instructional course lectures. The American Academy of Orthop. Surgeons 9:257.

- Behrens, S. (1980): Problematische Serienfrakturen der unteren Extremität bei Motorradfahrem. Voordracht tijdens $25 \mathrm{e}$ Unfallseminar. Medizinische Hochschule Hannover.

- Van den Berg. P. (1972): Rewascularisation osteotomierter langer Röhrenknochen nach stabiler und instabiler Osteosynthese durch intra- und extramedulläre Krafträger. Ann. Univ. Sarav. Med. $19: 148$.

- Bernstein. S. (1974): Fractures of the femoral shat and associated ipsilateral fractures of the hip. Orthop. Clin. North. America 5:799.

- Bianchi. G. (1955): Le fratture del segmento inferiore del femore. Minerwa orthop. 6:49.

- Bircher, H. (1886): Eine nete Methode unmittelbarer Retention bei Frakturen der Röhrenknochen. Verhandly. dtsch. Ges. Chir.

- Böhler, J. (1966): Gedeckte Markdrahtung der Vorderammburche Erwalchsener. Aktuclle Chinurgic 1: 15 .

Böhler. L. (1943): Vorschlag zur Marknagehung nach Kuntscher bei frisehen Oberschenkelschussbrüchen. Chirupg $15: 8$.

- Bonnin. J. (1946): A complete out tine of fractures. Ed.: William Heinemann - Medical Books L. fd. London.

- Böner. M.: Mock witz. J.; Soldner. E. (1983): Indikationen für dic Verriegelungsmagehung am Obersehenkel bei Trümmer-, Stück- und Etagenfrakturen. Hefte Unfallheilkunde $|6|: 61$.

Börner. M.: Winter-Klemm. B.; Klemm, K. (1982): Der gefallene Itearos oder der sehwerverletate jugendliche Motorradfathrer. Dic graucnvolle Jahresbillanz einer Unfallk linik. Unfallehirurgie $8: 1$.

- Braden, T.: Brinker. W. (1976): Riddiologic and gross andtomic evaluation of bone healing in the dog. J. Am. Vet. Med. Assn. 169:131\%.

- Brav. E. (1957): Further evaluation of the use of intramedullary nailing in the treatment of gunshot ftactures of the extremities. J. Bone Joint Surg. 39-A: 513.

Brussatis. F. Platass, U. (1975): Dokumentierte Ergebnisse der A.O-Marknagelung bei Frakturen des Femurs und der Tibia. Med. Orthop. Technik $5: 112$.

- Brookes. M. (1971): The blood supply of bone. Ed.: Butterworths Londen, 1971.

- Brookes, M.: Elkin, A.; Harrison, R.; Heald. C. (1961): A new concept of capillary circulation in bone cortex Lancet I : 1078 . 
- Bruns. P. (1886): Die Lehre von den Knochenbrüchen. Ed.: Enke. Stuttgart.

- Bull. J. (1975): Scverity score of road traffic casualties in relation to mortality, time of de atts, hospital treatment lime and disability. Accid. Anal. Prev. J. ? : 249.

- Burny, F. Zueman, J, Bourgeois, R.; Aubriot, J. Sedel, L. (1971): Utilisation des jauges exicnsonétriques pour la mesure de la consolidation des fractures du tibia traitées par enclouage centro-medullatre. Acta Orthop. Belg. 37:266.

- Buxton. R. (1984): The use of Perkins traction in the treatment of femoral shaft fractures. J. Bone Joint Surg. voll, 63-B, 3:362.

- Carr. C.: Miller. M.: Charlotic. N. (1958): Management of difficult fractures of the femoral shaft, South. Med. I. vol. \$1: 642 .

- Cancy. M.; Chapman, M. (1979): Ipsilateral concomitant fractures of the hip and femoral shaft. 1. Bone Joint Surg, voll. 61-A, $4: 503$.

Charnlcy. I. (1947): Knce mowement following fractures of the femoral shaft.

I. Bone Joint Surg. voll. $29,3: 679$

- Charnley. I. (1974): The closed treatment of common fractures. Ed.: Churchill Livingstone. Edinilyurgh.

- Charntcy. I. Guindy, A. (1961): Delayed operation in the open reduction of tractures of long bones. I. Bone Joint Surg. vol. 43-B, 4:664.

- Comolly. J.; Dehne. E.: Lafollette. B. (1973): Closed reduction and early cast-brace ambulation in the treatment of fomoral fractures. J. Bone Joint Surg. vol. 55-A. 8: 1581.

- Dambe. L. (1971): Revascularisation der Diaphyse langer Röhrenknochen nach Fraktur und Ostcesynthese. Med. Diss. Universitä des Satarlandes. Homburg.

- Damholt. W.: Zaravkovic. D. (1972): Quadriceps function following fractures ol the femorat shaft. Actil Orthop. Seand. $43: 148$

- Danckwardt-Lillieström. C. (1969): Reaming of the medultary cavity and its effects on diaphyseal bons: a fluorochromic, microangiographic and histologic study on the rabbir tibia and dog femur. Actal Orihop. Scand. Suppl. 128.

- Danckwardt-Lilliesurom. C, Lorenzi, L.; Olerud, S. (1970): Intramedullary nailing after reaming. An investigntion on the healing process in osteotomized rabbits. Acta Orthop. Scand. Suppl. 134.

- Deaner. R.: Fitchett, V. (1975): Motorcyele trauma. J. Trauma wol, 15,8:678.

- Debrunner, A. (1967); Biomechanische Wirkungen der posttraumatischen Achsenfehler der unteren Extreminat. In: Postraumatische Achsenfehlstellungen an den unteren Extremitäten, $39: 54$.

Ed.: Hans Huber Verlag. Bern.

- Dencker. H. (19)63): Fractures of the shaft of the fenur. Ed.: Orstadius Boktrycheri akticbolag. Goitcborg.

- Dichl. K. (1976): Stabilitat und Beanspruchung von Osteosynthesen des Ober- und Unterschenkels bei der Fribumobilisation. Unfallheilkunde $79: 81$.

- Dush. J.: Dupuis. M. : Beck, G. (1983): Strahlungsmessungen bei Verriegelungsnagelungen. Hefte Untall heilkunde $\mid 61: 36$.

Drysdate, W. : Kraus, I ; Franti, C, Riggins, R. (1975): Injury patterns in motorycle collisions. 1. Tramma vol. $15,2: 09$.

- vin Duyn, C. (1977): Fracturen van het distate deel van het fermur. Dissentate, Groningen.

Dunn. D. (1952): Anteversion of the neck of the femur. A method of management. J. Bone Joint Surg. vol. 34. 2:181.

Dupus. M. (1977): Strahlenbelastung während der Verricgelungsnagelung $1 \mathrm{E}$ : 13. In: Grosse und Kempit. Handbuch der Verriegelungsnagelung bei Schaftbrühen von Femur und Tibia.

Ed.: Howmedica

- Dupuis, M.; Grossi. A. (1978): Zur Problematik der Strablenbelastung bei der Vernegelungsnagelung In: Vorricgelungsnagelung. Symposium, II : 63. Ed. Verlag Wilhelm Minudrich. Wenen.

- Ehrlich. W. (1965): Fehter bei der operativen Knochenbruclabehandlung und ateren Vermeidung. Zentralbl. Chir. 24:922.

Eid. A.; Deif, A. (1980): Actiological factors in non-uniwn following Küntscher intramedullary wailing of the femur. Arch. Orthop. Traumat. Surg. $96: 213$.

- Fited, F.: Dambe, L.: Klapp. F.: Schweiberer, L. (1976): Vaskutarisation der Diaphyse langer Röbrenknodion unter Cerelagen. Unfaltheilkunde 79 : 41 . 
- Eitel. F.: Klapp. F. Seller. H. (198) : Fragmentnekrese. Experimentelle Untersuchungen der corticalen Revascularisierung bei Platten- und Marknagelosteosynthese.

Hefte Unfallheilkunde 153: 195 .

- Eitel, F.: Schenk, R.; Schweiberer, L. (1980): Conticale Revitalisierung nach Marknagelung an der Hundetibia. Untallheilkunde $83: 202$.

- Eriksson. E.; Hovelius. L. (1979): Ender nailing in fractures of the diaphysis of the femur. I. Bone: Joint Surg. 61-A. 8: 1175.

- Evard. J.; Lebard, J. (1971): Pseudarthroses infectés de la diaphyse fómorate.

Rev. chir. orthop. $57: 527$.

- Ewen. K.: Schmitu. G. (1974): Technische Strahlenschutzmassnahmon am chirurgischen B.V. Röntgenpraxis $27: 216$.

- Ewen. K.: Wahl. H. (1976): Die Strahenbehastung des Unfallehiturgen beim Arbeiten mil dem chirurgischen Bildverstarker. Röntgenpraxis $29: 163$.

- Fischer, S. (1973): Rontgenstrahenbelastung bei gesehlossener Oberschenkelverkürangsasteolomic. Chirarg $44: 171$.

- Fraser, R.: Hunter, G.: Waddell. J. (1978): Ipsiateral fracture of the femur and tibia di. Bone Join Surg. vol. 60-B, $4: 510$.

Funk. F.; Welis. R.; Street, D. (1968): Supplementary fixation of femoral fractures.

Clin. Orilhop. $60: 41$.

- Funsten, R.; Kinser, P.; Frankel, C. (1938): Dashboard dislocation of the hip.

J. Bone Joint Surg. $20: 124$.

- Galle. P.; Strickner. M.; Schnid. L.; Spangler. H. (1981): Enfahrungen bei 245 geschlossenen Marknagelungen des Oberschenkels. Unfallchirurgie $7: 162$.

Gillquist. J.; Rieger. A.; Sjödahl, R.; Bylund, P. (1973): Multiple tracures of a single leg.

A therapeutic problem. Acta Chir. Scand. 139:167.

- Gluck, Th. (1890): Die Invaginationsmethode der Osteo- und Arthroplastik.

Berliner Klin. Wschr. $732-752$.

- Gogler, E. (1968): Chirurgie und Verkehrsmedizin, Uit: Handbuch der Verkehrsmedizin.

Ed.: Wagner, K., Wagner, H., Springer - Berlin.

- Goris, R. (1983): The injury severity score. World J. Surg. 7: 12.

- Göthman, L. (1960): The arterial pattern of the rabbit's tibia after the application of an intramedullary nail. Acta chir. Scand. 120:211.

- Göthman. L. (1961): Arterial changes in experimental fractures of the monkey's tibia treatcd with intramedulary nailing. Acta chir. Scand. $121: 56$.

- Gotzen, L.; Bethrens, S.; Suren. E.; Richter, K.; Stürt, G. (1974): Zur Epidemiologie und Biomecharik des Fussgängeruntalles alter Menschen. Hefte Unfallheilkunde $121: 443$.

- Grosse. A. Lafforgue. D.; Weigel. A. (197\%): Zielgeräte zur Verricgelung II : 53. Uit: Verriegelungsnagelung symposium Wenen. Ed.: W. Maudrich Verkg. Wenen

- Hads. N.: Mubr, G. Tscherne. H. (1980): Kombinatonsfrakturen von Femurschaft und proximalsm Femurende. Untaltheilkunde $83: 245$.

- Hackethal. K. (1961): Die Bündelnagelung. Ed.: Springer Verlag. Wien.

- Harms. J. v.d. Berg. P.; Mertz, C. (1674): Knochenrevascularikstion nach Refobacin - Palateos Füllung. Arch. Orthop. Unfall. Chir. $80: 71$.

- Heim. H. (1943): Marknagelung von Oberschenkelschussfrakiuren. Chirurg 13:347.

- Heine. C. (1875): Citaat uit: Brums. P. (1886): Die Lehre won den Knochenbrühen, Ed: Enke. Stuttgart.

- Herzog. K. (1951): Verlängerungsosteotomic unter Verwendung des perculan gezich verricgetten Manknagels. Hefte Unfallheilkunde $42: 226$.

- Hey Groves. E. (1918): Unumited fractures, with speciad reference to gunshot injurics ind the use of bone grafting. Br. I. Surg. vol. 6, 22: 2613.

- Hildebrandt, G. (1979): Dic Bedeutung der periossären und intramedultären Durchblutung für dic Entstehung der postraumatischen Osteomyelitis und für die Wahl des Osteosyntheseverfithrens. Beitr. Orthop. w. Traumat. $26: 181$.

- Hofmann, C.: Probst. J. (1982): Anwendungsmöglichkeiten des Fixateur Externo am OberschenkelIndikationen, Ergebnisse. Akt. Traum, $2: 62$.

Höger, H.; Gillquist. J.; Liljedahl, St. (1978): Intramedullary nailing of femoral-shaft fratertes. Unfallheilk. $81: 398$. 
- Hoglund, E. (1917): New method of applying autogenous intramedullary bone-transplants and of making autogenous bone-screws. Surg. Gynecol. Obstet. 24: 243.

- Holden. C. (1972): The role of blood supply to soft tissue in the healing of diaphyseal fractures. J. Bone Joint Surg. 54-A:993.

- Höster, G.; B̈ohm, E. (1981): Corticate Durchblutungsstönungen nach Fraktur und Osteosynthese. Hefte Unfaltheikunde 153:17.

- Hudec, M.: Hancevic, J.: Schellmann, W. (1977): Ueber das mechanische Zusammenwirken von Implantaten und Knochen nach verschiedenen Osteosyntheseverfahren (analytische und experimentelle Studie). Hefte Unfallheilkunde 129:21.

- Jahna, H.: Wittich. H. (1976): Konservative und operative Behandlung der Mehrfragmentbrüche atm Oberschenkel (Erfahrungen bei 180 frischen Fällen des Erwachsenen, davon 81 Spätnachuntersuchungsergebnisse). Unfaltheilkunde $79: 165$.

- Joost van, M; Gastkemper. R. (1972): Malrotation after temoral shaft fractures. A.rch. Chir. Neert XXIV-II : 101.

- Karlstrom, G,; Olerud, S. (1977): Ipsilateral fracture of the femur and tibia. J. Bone Joint Surg. vol. 59-A, $2: 240$.

- Kempf. J.; Grosse, A. (1980): Ergebnisse biomechanischer Untersuchungen nach Verriegelungsnagelung. Darstellung des Strassburger Instrumentars und Zielgerätes. Unfitl. med. Tagungen $42: 221$.

- Kempl. I.: Jacger, J.; Clavert. J.; Mochel, D.: Glaesener. R. (1978): Lenclouage centro-médullaire avec alésage. Critique therorique el experimentale des principes de Küntscher.

Rev. chir orthop. $64: 629$.

- Kempt. I.: Jacger, J.: Weigel, A. (1978): Biomechanische Untersuchungen zur Verriegelungsnagelung. In: Verriegelungsnagel ung symposium Wenen. Ed.: W. Maudrich Verlag. Wener.

- Kessler, S.; Rahn, B.; Schweiberer, L.: Perren, S. (1983): Die revascularisation von Intermediarfragmenten nach Verriegelungsnagelung. Hefte Unfallheilkunde $161: 38$.

- Kimbrough, E. (1961): Concomitant unilateral hip and femoral-shaft fractures - A too frequently unrecognized syndrome. J. Bone Joint Surg. vol. 43-A, 3: 443.

- Klemm, K. (1971): Die modifiziente Trümmerbruchnagelung zur Stabilisierung der infizierten Pseudarthrosen am Oberschenkel. Hefte Unfallheilkunde $110: 240$.

- Klemm, K. (1973): Die Stabilisierung infizierte Pseudarthrosen mit dhen Verriegelungsnagel. Langenbecks A.rch. Chir. $334: 559$.

- Klemm. K. (1978): Die Trümmerfrakturen des Femur und der Tibia. In: Verriegelungsnagelung. symposium, Wenen. Ed.: W. Maudrich Verlag. Wenen.

- Klemm, K. (1983): persoonlijke mededeling.

- Kalemm. K: Schellmenn, W. (1972): Dynamische und statische Verriegelung des Marknagels. Msclar. Untallheillk. $75: 568$.

- Klomm. K.: Schellmann. W. (1976): Die Verriegelungsnagelung. Akt. Traum. 6 : 377.

- Koolstra, G. (1973): Femoral shaft fractures in adults. Dissertatie, Groningen.

Koudelka, J. (1931): Mehrfache Knochenbrüche. Tschech. Slov, Sborn. Ortop. 6: 208.

Koudsi, F, Kirschner, P. (1977): Die Behandlung der Mehrlachfrakturen am Fenur. Untallheilkunde $80: 89$.

- Kuderna, H. (1975): Ergebnisse der gedeckten Unterschenkelmarknagelung in den Arbeitsunfallkrankenhäusem Oesterreichs. Hefte Unfaltheilk. 119:60.

- Kuderna. H. (1978): Kritische Bemerkungen zur Konstruktion des Verriegelungsmagels nach Klemm und Schellmann. In: Verriegelungsnagelung symposium, Wenen $5: 143$. Ed.: W. Maudrich Verlag. Wenen.

Kuner, E.; Weller, S.; Simon, G. (1969): Der Oberschankel-Mehrfragmentenbruch im Schaftbereich. Disch. Med. Wsehr. 13:645.

- Küntscher, G. ( (940): Die Marknagelung von Knochenbrüchen.

Langenbecks Arch. Klin. Chir. $200: 443$.

- Küntscher. G. (1960): Zur Marknagelung des Trümmerbruches. Chirurg 31:503.

- Küntscher, G. (1962): Praxis der Marknagelung. Ed.: Schattauer Verlag, Stuttgart.

Küntscher, G. (1964): Die Nagelung des Defekttrummerbruches. Chirurg 35: 277.

Küntscher, G. (1967): Die gedeckte Osteosynthese. Act. chir. 2 : 365.

Küntscher, G. (1968): Die Marknagelung des Trummerbruches.

Langenbecks Arch. Klin. Chir. 322: 1063. 
- Küntscher, G.; Maatz, R. (1945): Technik der Marknagelung. Ed.: Thieme, Leipzig.

- Laftman. P.; Sigurdsson, F.. Strömberg. L. (1980): Recovery of daphyseal bone strength affer rigid. internal plate fixation. An experimental study in the rabbit. Acta Orthop. Seand. $51: 215$.

- Lambotte, A. (1892): Notice sur lemploi du fil de fer er de wis du mème metal dans la sutur osseuse. Presse med. Belge $44: 125$.

- Lambotre. A. (1907): Le trattement des fractures. Ed.: Masson, Paris.

- Lambotte, A. (1913): Chirurgie opératoires des fractures. Ed.: Masson. Paris.

- Landelius (1951) Geciteerd door Scharizer (1964). Hefte Unfallhcilkunde $79: 47$.

- Leitz. G. (1968): Typische Komplikationen mach Osteosynthesen und ilme mechanischen Ursachen. Arch. Orthop. Unfall. - Chir. $64: 285$.

- Lejahrs. F. (1902): Technik dringlicher Operationen (Bhutiger Reposition und Vereinigung von Frakturenden). Ed.: G. Fischer. Jena.

- Lemmens. H. (1981): Intra-operative hazards and complications of intramedullar fixation. Voordracht: Instructional collise on intramedullary fixation of fractures, Maastricht.

- Lemmens. H. (1984): Raynaud-Patienten: Lebensqualitat oder Ausschopfung der Therapie. In: die ärtzliche und psychologische Betreung der Gefässpatienten, 65-70. Ed.: T.M.-Verlag G.m.b.H. Hameln.

- Lüscher, J.; Rüedi, Th.; Allgöwer, M. (1978): Erfahrungen mil der Plattenosteosynthese bei 131 Femurschaft-Trümmerfrakturen. Helv. Chir. Acta $45: 39$.

- Maatz. R. ( 1962$)$ : Drehfehler an Ober- und Unterschenkel nach Marknagelung. Zentrabl. Chir. $87: 1373$.

- Maatz, R.; Lentz. W.; Arens, W.; Beck. H. (1983) Gedeckte oder offene Nagelung 11 : 42. In: Dic Markungelung und andere intramedullare Osteosynthesen. Ed. F, K. Schattucer Veriag. Stuttgart New York.

- Maess, M.; Tausch, W. (1980): Erfahrungen mit der operativen und konservativen Behandlung der Oberschenkelschaftirakturen. Zentralbl. Chir. 105: 1127.

- Maroske. D.; Thon. K. (1983): Die Verriegelungsnagelung am Oberschenkel: Alternative oder Konkurrenz zu anderen Osteosyntheseverfahren? Hefte Unfal heilkunde $161: 67$.

- Marti. R.; van der Werken, Chr. (1982): Alternative indications for extermal fixation according to Wagner. Neth. J. Surg. 34-3; 127.

- Marty, A. (1969): Zur geschlossenen Marknagelung mach Untersehenkelfrakturen. Act. Helv. Chir. $36: 136$.

- Messerer, O. (1880): Ueber Elastizität und Festigkeit der menschlichen Knochen. Ed.: Stutgart 1880.

- Meuli, H. (1966): Zur operativen Behandhung der Femurschaft rakturen. Act. Helv. Chir. $33: 222$.

- Mihula, A. (1973): The sources of healing of a fracture of tubular bone in different iypes of osteosyntheses from the standpoint of vessel supply. Rozhl. Chir. $52: 35$

- Mockwiz, J. (1981): Versorgung von Oherschenkeltrümerbrüchen mit dem Verricgelungsnagel. Hefte Untallheilkunde $153: 209$.

- Mockwitz. 1. (1982): Korrektur von posttraumatischen Fehlstellungen im Bereich des Oberschenkelknochens mit dem Verriegelungsnagel. Akt. Traum. 12:303.

- Mockwitz. J.: Contzen, H. (1983): Die Verriegelungsmagelung. Helte Unfallheilkunde 161.

- Mommsen. U.; Bock-Lamberlin. P. I Iungbluth, K. (1983): Indikation fur die Verriegelungsnage lang ann mittleren Oberschenkeldrittel. Hefte Unfallheilkunde $161: 45$.

- Morschor. E. (1967): Prophylaxe und Therapie drohender oder bestehender Achscnfehlstellungen beim Kind. In: Positraumatische Achsenfehistellungen an den unteren Extremitaten, 111:116. Ed. Hans Huber Verlag. Bern.

- Mühe (1977): Citaat uit: Schllegel. K.F.: Dic Krankengymnastische, physikalische und beschäftigungstherapeutische Begleibehandlung von Verletzungen in der Frühphase. Hefte Unfallheilkunde vol. $138: 232$.

- Muhr, G.; Tscherne, H.; Trentz. O.; Haas. N. (1976): Die Osteosynhese mit Marknagel und zusitzlichen Drahtumschlingungen bei Obersehenkelschaftbrüchen. Aku. Traum. $6: 387$.

- Müller. M. (1979): Indikationen, Komplikationen und Ergabrisse in dier Behandlung infizicrter Femuar - Pseudarthrosen. Arch. Orthop. Traumat. Surg. $94: 299$.

- Müller. M. (1980): Klassifikation und internationate A.O. Dokumentation der Femurfrakturen. Untallhcilk. $83: 251$.

- Muller. M.: Allgower. M; Schneider, R.; Willenegger, H. (1977): Manual der Osteosynthese - A.O. Technik. Ed.: Springer Verlag, Bertin. 
- Maller - Meemach (1933): Dic Bolzung der Brüche der langen Röhrenknochen.

Zentrabl Chir. $29: 1718$.

- Nagel. D.: Buntom, D.; Manning J. (1979): The dashboard knee injury. Clin. Orthop. $126: 203$.

- Neer. C. Grantham. S.; Shelton. M. (1967): Supracondylar fracture of the adult femur. J. Bone Joint Surg vol. $49 \cdot$ A. 4: 591 .

Nekon. G.; Kelly, P.; Peterson, F.; James, I. (1960): Blood supply of the human tibia. J. Bone Joint Surg. 42-A: $: 625$.

- Nicod. L. (1967): Eifets ctiniques et pronostics des défauts d'axe du membre inférieur chez l'adulte. à la suthe d'une consolidation vicieuse dune fracture du membre inférieur. 1. Teil. $57: 78$.

In: Postraumatiche Achsenfehlstellungen an den unteren Exiremilaten. Ed.: Hans Huber Verlag. Bern.

- Nichols. P. (1963): Rehabilitation after fractures of the shaft of the femur.

J. Bone Joint Surg. 45- B. 1:96.

Oestern. H.: Tscherne, H. (1983): Pathophysiologie und Klassifikation des Weichteilschadens. Hefre Untallheilkunde $162: 1$.

- Olcrud. S.: Danckwardt-Lillieström, G. (1968): Fracture healing in compression osteosynthesis in the dog. J. Bone Joint Surg. 50-B : 844 .

Olsson. O. (1949): Some eases of necrosis of the bone by encircling suture (cerclage) in oblique fractures. Acta Chir. Scand. 99:85.

- Onoue, Y.: Sunami, Y.; Fujwara, H.; Sadakane, T.; Yasuda. S. (1979): Treatment of the femoral shat fracture with a curved heat-freated COP Clover-leat Natl.

International Orthopaedies (SICOT), $3: 203$.

- Pankovich. A.; Goldflics, M.; Pearson. R. (1979): Closed Ender nailing of femoral-shaft fractures. J. Bonc Joint Surg. vol. 61-A, $2: 222$.

- Parsch, K.; Zu Eulenburg. F. (1981): Küntscher nailing of femoral shaft fractures in children. In: Fractures in children, 242. Ed.: Georg Thieme Verlag, Stutgart - New York.

- Perkim, G. (1953): Rest and movement. J. Bone Joint Surg. 35-B:521.

- Pfister, U, Rabn, B.; Perren, S.; Weller, S. (1979): Vascularität und Knochenumbau nach Marknagelung langer Rohrenknochen. Akt. Traum. 9: 191.

- Povacz, F. (1979): Verbrennungsschaden an der Tibiadiaphyse nach Marknagelung mit Aufbohren. Untallheilk. $82: 126$.

- Rand, J.; An, K.; Chao, E.; Kelly, P. (1981): A comparison of the eflect of open intramedullary mailing and compression-plate fixation on fracture-site blood flow and fracture union. J. Bone Joint Surg, voi. 63-A: 427 .

- Raisch, 0. (1943): Marknagelung bei frischen Oberschenkelschussbrïchen? Chirurg 13:381.

- Rehn, I.; Schramm, W,; Hierholzer, G. (1968): Zur Indikation und Technik der Umstellungsostcotomien wegen Fehlstellung nach Frakturen der unteren Gliedmassen.

Arch. Orthop. Untall. Chir. 63:9.

- Rehnm, J.; Uebing. D. (1963): Die Behandlung von Frakuren langer Röhrenknochen mit dem Marknagel nach Küntscher. Arch. Orthop. Unfall. Chir. 55: 82 .

- Rehn: Wakbaiaky (1911): Die Hornbolzung im Experiment und ihre klinische Verwendung. Arch Kllm. Chir $96: 449$.

- Reinders, J, Mockwitz, J, (1984): Techrical faults and complications in interlocking nailing of femoral and tibial fractures. Act, Orthop. Belg. 50-5,577.

- Reschauer, R.: Sayszowitz. R., Paul. K. (1979): Die Stabilisierung von Frakturen des Femurschaftes mit Marknagel und Cerclagen. Unlatlchirurgie $5: 158$.

- Reynolds, F. Key, J. (1954): Fracture healing after fixation with standard plates, contact splints and medullary mails. An experimental study. J. Bone Joint Surg. 36-A : 577.

- Rhinelander. F. (1968): The normal microcirculation of diaphyseal cortex and its response to fracture. J. Bone lloint Surg. vol. 50-A. 4:784.

- Rhinelander, F. (1972): Circulation in bone. In: The biochemistry and physiology of bone. thfst. I. vol. II. Ed: Bourne, Academic Press, New York-Londen.

Rhinclander, F. (1974): Tibial blood supply in relation to fracture healing. Clin. Orthop. $105: 34$.

Rhinelander, F. (1980): Vascular proliteration and blood supply during fracture healing. In: Uthoff. K.: Current concepts of internal fixation of fractures. Ed.: Springer, Berlin. Heidelberg. New York.

- Rhinelander, F.; Baragry, R. (1962): Microangiography in bone healing.

1. Bone lloint Surg. 44-A; 1273 
- Rippstein. J. (1955): Zur Bestimmung der Antetorsion des Schenkelhalses mintels zweier Röntgenaufnahmen. Z. Orthop. 86:345.

- Ritchey. S.; Schonholtz, G.; Thompson, M. (1958): The dashboard femoral fracture. J. Bone Joint Surg. vol. 40. A, 6: 1347 .

- Roberts. J. (1977): Management of fractures and fracture complications of the femors shalt using the ASIF Compression Plate. J. Trauma vol. 17, 1:20.

- Rothweli. A.; Fitzpaltrick. L. (1978): Closed Kuntscher nailing of femoral shaft fractures. J. Bone Joint Surg. vol $60,13: 504$.

- Rush. L. (1955) Athas of Rush pin Techmics. Ed.: Meridian Miss. U.S.A. Berivon Comp.

- Salem. G. (1961): Zur Frage der stabilen Ostosynthese bei Oberschenkeltrummerbrüchen. Chirurg $2: 78$.

- Sarmiento. A. (1972): Functional bracing of tibial and femoral shaft fractures. Clim. Oribop $82: 2$.

- Sarmiento, A.; Latta. L. (1981): Closed functional treatment of fractures. Ed.: Springer Verlag. Berlin. Heidelberg. New York.

- Schauwecker. F. (1972): Die Frage der Stabilitït einer Osteosynthese in Bezug auf Uebungsbehandhung und Belastung. Krankengymnastik $5: 158$.

- Schellmann. W. (1982): Verbesserung der Küntscher-Nagel-Technik. Chinury 53:737.

- Sehellmann, W.; Klemm, K. (1979): The treatment of pseudarthroses with interlockng naiks. In: Psevdarthroses and tibia treatment. Ed.: George Thieme Publishers Stultgart (1979).

- Schlegel. K. (1977): Die Krankengymnastische, physikalisch und beschät igungs-therapeutische Begleibehandhung von Verletzungen in der Frühphase. Hefte Unfallhoilkunde vol. $1,38,232$.

- Sehöne, G. (1913): Zur Behandlang von Vorderarmfrakiuren mil Bolzung. Müncher Med. Wschr, LX: 2327 .

- Schötle, H.; Jungbluth, K.: Saner, H.; Schöntäg, H. (1978): Weichteilverknöcherungen nach stabilen Osteosynthesen durch Knochenbohrmeht. Chururg $49: 49$.

- Schweibarer, L. (1978): Nekrosepseudarthrose. Hefte Unfallheilkunde $\$ 1$ : 228

- Schweiberer. L.: van den Berg, P.; Dambe. L. (1970): Das Verhaten der intrassaren Getisse nach Osteosynthese der fratkurierten Tibia des Hundes. Therapiewoche $20: 1330$.

- Schweiberer. L.; Dambe, L.; Eitel, F, Klapp. F. (1974): Revalscularisation der Tibia nach konserwattiver und operativer Frakturenbehandlung. Hefte Unfallbeilkunde $119 ; 18$.

- Schweiberer. L.; Lindemann, M. (1973): Infektion nach Marknagelung. Chirurg 44: 542.

- Sjövall. H. (1957): Die Formen der Frakturen der liangen Röhrenknocher.

Zentralbl. Chir. 30: 1234.

- Slätss, P.; Ryoppy, S.; Huittinen, V. (1971): A.O.-nsteosynthesis of fractures of the distal third of the femur. Acta Orthop. Scand. $42: 162$.

- Smillie. I. (1954): Dashboand fracture of patella. British Med. J. $2: 203$.

- Smith, I. (1964): The results of carly and delayed internal fixation of fanctures of the shat of the femer. 1. Bone Join Surg. vol. 46-B. 1:28.

- Socin ( 1879$)$ : Beitrage zur operativen Behandung gebrochener knochen. Jahresberich der Chir. Klinik Basel 80.

- Spirig. B. (1967): Die Diagnose der Achsenfehler der unteren Extremitá. In: Pustraumatixehe Achsentehlstellungen an den unteren Extremitaten. 1. Teil : 9. Ed.: Hams Huben Vorlag Bern.

- Stapert, J. (1983): Intramedullare osteosynthese wan het femur. Dissertalic. Madstricht.

- Stewart, M.; Sisk. T. Wallace. S. (1966): Fractures of the distal third of the femenr. I. Bone levint Surg. 48. A : 784 .

- Stobrer, M.; Preis, G.: Georgi, P.; Langhoff, J.; Franke. D. (1972): Untersuchungen aber den Einfuss won Cordagen auf die Durchblutungs-Verbiltnisse an Hundeknochen. Langenbecks Arch. Chir. (Suppl.). Chir. Forum : 23 .

- Stryker. W.; Fussell. M.: West. H. (1970): Comparison of the results of operative and non-operative treatment of diaplyseal fractures of the femur at the Naval Hospitall. San Diego. over a five yeatr period. A. Bone Join Surg. 52-A : 815 .

- Stïrmer. K.: Sehuchardt. W. (1980): Neue Aspekfe der gedeckton Marknagehung und des Aubohrens der Markhöhle im Tierexperiment. 1. Die Schaftstibia als Tiermodell lia die Markragelung. Unfallheilk, $83: 341$.

- Sturmer. K.: Schuchardt. W. (1980): Neue Aspekte dergedeckten Marknatgelung wnd dos Aufbohrens der Markhöhle irn Tierexperiment. VI. Der intramedulläre Druck beim Aufhotuen der Markhohle. Unfallheilk. $83: 346$. 
- Stürmer, K.: Schuchardt. W. (1980): Netue Aspekte der gedeckten Marknagelung und des Aufbohtens der Markthöhle im Tierexperiment. III. Knochenheilung. Gefïssversorgung und Knochenumbau. Unfallheilk. $83: 433$.

- Thomas. T.: Meggitt. B. (1981): A comparative study of methods for treating fractures of the distal hat of the fermur. J. Bone Joint surg. 63-B, $1: 3$.

- Tonino, A.; Duvidson, C.; Klopper, P.: Lindlau, L. (1976): Protection from stress in bone and its effects. Experiments with stamless sted and plastic plates in dogs.

J. Bone Joint Surg. wol. 58-B, $107: 13$.

- Trajan, E.: Vècseï, W., Wruhs, 0. (1983): Indikationen für die Verriegelungsnagelung an Oberschenkel im distalen Drittel. Hefte Untallheilkunde $161: 53$.

Trueta. J, Cavadias. A. (1955): Vascular changes caused by the Kuntscher type of nailing.

An experimental study in the rabbit. J. Bone Joint Surg. voll. 37-B, 3:492.

- Tructa.. J.: Cavadias, A. (1964): A study of the blood supply of the long bones.

Surg. Gyn. Obstet. woll 118.3:485.

Tscherne. H.; Szyskowitz, R. (1968): Mehrfragmentbruche des Fenurschaftes.

Mschr. Unfat heilkunde 71 : 103 .

- Tscherne, H. : Trentz, 0. (1977): Operationstechnik und Ergebnisse bei Mehrfragment- und Triummerbrichen des Femurschaftes. Unfallheilk. $80: 221$.

Uhthoff, H. : Dubuc, F. (1971): Bone structures changes in the dog under rigid internal fixation. Clin. Orthop. $81: 165$.

- Uhthoff, H.; Finnegan, M. (1983): The effects of metal plates on post-traumatic remodelling and bone mass. J. Bone Joint Surg. vol. 65-B, $1: 66$.

- Vècseï, V. (1978): Verriegelungsnagelung. Symposium Wenen. Ed.: W. Maudrich Verlag. Wenen.

- Vècseï, V. (1980): Der Dübelbolzen - eine Ergänzung zur Verriegelungsnagelung. Unfallchirurgie 6, 3:193,

- Vècel, V. (1983): Grundlagen der Verricgelungsnagellung - Biomechanische Grundlagen. Hefte Unfallheilkunde $161: 24$.

- Viernstein, K.; Bezouglis, C.; Gordes, W. (1971): Die Kettenfrakturen der unteren Extremitäten. Akı. Traum. 1:75.

Vollmar. J. (1960): Der Knicanprall, cin häufiger Verletzungsmechanismus bei Auto- und Molorradfahrem. Langenbecks Arch. Klin. Chir. $295: 315$.

- Voorhoeve. A.: Sternomann, H. (1973): Beitrag zur Behandlung von Kombinationsfrakturen des Oberschenkets. Mschr. Unfallheilkunde $76: 376$.

Wagner, K.; Wagner. H. (1968): Handbuch der Verkehrsmedizin. Ed.: Springer, Berlin.

Wang, G.; Dunstan, J.; Reger. S.; Hubbard, S.; Dillich, J.; Stamp, W. (1981): Experimental femoral fracture immobilized by rigid and flexible rods (a rabbit model). Clin. Orthop. Research $154: 286$.

- Warmbrod, I.: Yelton, Ch.; Weiss, A. (1976): Intramedullary nailing of femoral shaft fractures. Clin. Orthop. $114: 2 \times 2$.

- Weigert, M.; Viernstein, K. (1968): Die Aussendrehtehlstellung nach Oberschenkelmarknagelung. Z. Orthop. $104: 567$.

- Weiss. H.: Schmit.Neuerburg, K.: Stürmer, K. (1981): Experimentelle Untersuchung zur Einheilung vascularisierter Schattsegmente bei Marknagel-Osteosynthesen.

Langenbecks Arch. Chir. 1981 - suppl. 18.

- Weiss, H.; Schmit-Neuerburg, K. (1983): Tierexperimentelle Erfahrungen mit dem Verricgeltungsnagel bei der Versorgung von Tibia-Etagenbrichen. Hefte Unfallheilkunde 161 : 11.

- Wentninger. H. (1975): Goetzedrähte und gedeckte Marknagehng bei Untersehenkeldrehbrüchen Erwachsener. Hefte Unfallheilkunde 119:81,

* Westhues, R. (1943): Kriegsehirurgische Erfahrungen. Zur Behandlung schwierigen Extremititicnschussbruche mit ausgedehnten Weichteilwunden. Chirurg $15: 13$.

- Whiteside. L.: Lesker. P. (1978): The effects of extraperiosteal and subperiosteal dissection on tracture healling. J, Bone Joint Surg. vol. 601-A. 26.

Wiend1. H. (1979): Stabile Ostcosynthese von Trümmerfrakturen unter zusätzlicher Verwendung won Cerclagen. Unfallheilk. $82: 36$.

- Wicsor, C. (1964): Die primäre Knochenbruchheilung und illue Störung im Röngenbild. Langenbecks Arch. Klin. Chir. $308: 434$.

- Wiber. M.; Exans, E. (1978); Fractures of the femoral shaft treated surgically. Comparative results ol early and delayed operative stabilization. J. Bone Joint Surg. wol, 60-A. 4: 489 . 
- Winquist, R.; Hansen. S. (1980): Comminuted fractures of the femoral shaft treated by intramodullary nailing, Orthop. Clin. North. America vol. 11, 3:633.

- Winquist, R. Hansen. S. Clawson, D. (1984): Closed intramedullary nailing of femoral fractures. 3. Bone Joint Surg. vol. 66-A, $4: 529$.

- Wittmoser. R. (1955): De geschlossene Marknagelung des Oberschenkelbruches. Langenbecks Arch. Chir. $282: 248$.

- Wolf. H.: Schauwecker, F.: Tittel, K. (1984): Rotationsfehler nach Markiagelung des Oberschenkels. Unfallchirurgie $3: 133$.

- Zenker. H. (1972): Zur Indikation und Technik korrigierender Osteotomien üm Schaftbereich langer Röhrenknochen. Arch. Orthop. Unfafl. Chir. 74: 205 .

- Zettas J. Zettas. P.: Thanosophon, B. (1979): Tnjury patterns in motorcycle accidents. J. Trama vol, 19,11:833.

- Zickel. R. (1980): Subrochanteric femoral fractures. Orthop. Clin. $11: 555$.

- Zimumerman. H. (1967): Beitrag zur offenen und geschlossenen Marknagehung vou Unterschenkelschafterakturen. Arch. Orthop. Unfall. Chir. $62: 205$, 


\section{DANKWOORD}

Allen die habben bigedragen aan de totstandkoming wan dit proefschrift wil ik van harte be danken. Prof. Dr. H, Lemmens was, als pionicr varde intramedullaire osteosynthesetechniek in Nederland. worr mij cen zecr deskundige gids, wiens adwezen en commentaren weel hebben biggedragen aan dit proctischritt.

Prof. Dr. I. Greep. dic op zijn cigen typische maarzeer dynamische manier heeft meegewerkt aan deze thesist, ben ik veel dank wersehuldigd.

Het idee voor dit proctschrift kreeg ik wan Dr, med. K. Klemm. Tijdens mijn verblijf in Frankfort leerde ik van hem de finesses van de Grendelpentechniek.

Prof. Dr. A. van der Linden ben ik dankbaar voor zijn nutig commentaar als referent.

Dr. J. Munting, die mij tot chirurg heeff opgeleid, ben ik dankbaar voor zijn kritische commentaren en voor het feit dat hij deze situdie voortdurend heeft aangemoedigd.

Dr. 1. Stapert was voor mij meer dan een referent. De vele avonden die wij samen discussiëerden over de inhoud van het proefsclorift zijn wan onschatbare waarde geweest bij het voltooien ervan.

De chirurgen van hee De Weverziekenhuis, Dr. J. Pinckaers. Dr. J. Munting. Dr. H. van Houtte. Dr. J. Lens en C. van Duin, die mij in staat hebten gesteld in de Berufsgenossenschaftiche Unfalklinik te Frank fort mijn kennis en wardigheden op het gebied wan de traumatologie uit te bouwen en die altijd het volste vert rouwen in het onderzock hebben gehad en mij waar mogelijk hebben gesteund. Prol. Dr, med. H. Contzen, die als hoofd van de Berufsgenossenschaftliche Unfallklinik te Frankfort mij de gelegenheid heeft gegeven de patiënten uit zijn kliniek te onderzoeken.

De medewerksters van de chirturgische polikllinieken in Heerlen en Frankfort die met veel volharding alle patiěnten voor het natonderzoek wisten op te sporen.

De medewerkers wat de medische archieven van het De Weverzekentuis en de

Berufigenossenschaftiche Unfallklinik die altijd behulpzam waren bij het verzamelen var de patientengegevens.

De direktic van het De Weverziekenthuis die het mogelijk maakte dat ook patienten die vanzeer ver moesten komen na-onderzocht konden worden.

De radiologic afdelingen van het De Weverziekenhuis en de Berufsgenossenschaftliche Unfallklinik die belangeloos de vele cu bewerkelijke "Bein-Ganzanfmahmen" hebben gernaka.

Allen die mij hebben geholpen met de vele foto's en illustraties: H. Willers. G. van Rooy. F. Goubhier.

P. Maessen en het fotolaboratorium van de Berufsenossenschafliche Unfallklinik.

De medewerksters wan de medische bibliotheken in beide zickenhuizen.

Harrie Schols en de paranynnfen Hans Vaessens en mijn broer Richard voor hun hulp bij de hele organisatic rond de promotic.

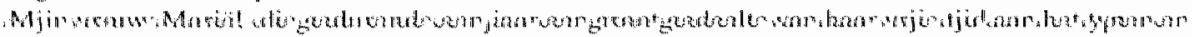

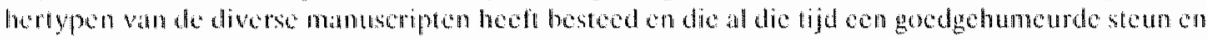
forvertan is geblevent.

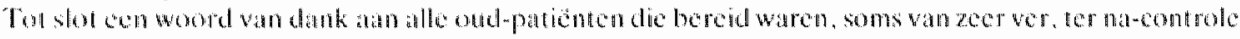
lie komen.

\section{CURRICULUM VITAE}

De aukur weral op 25 februari 1950 in Maststrich geboren, wath hij in 1969 het eindexamen Gymmatsium-13 behatale an het Hentic van Veddekecollege.

De studic Geneskunde wond plants and de Rijkstaniversiteit te Utrecht, waar in september 1975 thet antweximen weral verkerenen.

Van oktober 1975 tot 1977 verwalde thij zijn dienstplicht alls assistent orthopaedie in het Militair Hespitinal Dr. A. Mathijsen te Utrecht.

Sirvds 1977 is hij werkzadur in heet De Weverziekenhuis te Heerlen watr hij wan 1977 tot en met 1982 de opleiding tot thirurg an de afdeling A gemene Heck kunde (hoofd: Dr. A.D.K. Munting) volgde.

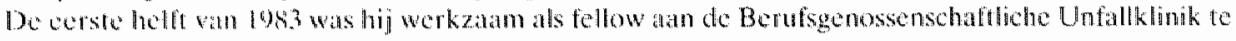
rankfort (hoofd: Prof. Dr. med. H. Concentis. 